\title{
Human Rights in Asia - selected issues
}

\author{
Edited by \\ Maria Ochwat
}




\author{
Series \\ Asia-Pacific Library \\ Editor-in-Chief \\ Joanna Marszałek-Kawa
}

Secretary

Bartosz Ptotka

\begin{abstract}
The Editorial Board
Kamal M. Abdulla (Azerbaijan), Daulet L. Baideldinov (Kazakhstan), Marceli Burdelski (Poland), He Yaomin (China), Hassan A. Jamsheer (Poland), Vasyl Marchuk (Ukraine), Joanna Marszałek-Kawa (Poland), Miao Huashou (China), Vladimir I. Nifadiev (Kyrgyzstan), Ewa Oziewicz (Poland), Zdzistaw Puślecki (Poland), Akmal Saidov (Uzbekistan), Grażyna Strnad (Poland), Peter Vorel (Czech Republic)
\end{abstract}

\author{
Reviewers \\ Professor Jerzy Sielski \\ Professor Maciej Walkowski \\ Publishing editor: Daniel Kawa \\ Technical editing: Ryszard Kurasz \\ Proofreading: Team \\ Cover design: Krzysztof Galus \\ (c) Copyright by Wydawnictwo Adam Marszałek
}

All rights reserved. The book you have purchased is the work of the author and the publisher. No part of it may be reproduced in any manner whatsoever without permission in writing from the copyright owner. In case of brief quotations of the work do not change the contents and make sure to note whose it is

Toruń 2020

\title{
ISBN 978-83--8180-508-7
}

The $7^{\text {th }}$ International Asian Congress "Building the Future of the State: Tradition, Reality, Progress” - a task co-financed under contract no. DNK/SP/466246/2020 from the Ministry of Science and Education funds allocated to the dissemination of science

Sales Department: tel. +48 5666422 35, marketing@marszalek.com.pl

Adam Marszałek Publishing House, ul. Lubicka 44, 87-100 Toruń tel. + 485666422 35, e-mail: info@marszalek.com.pl, www.marszalek.com.pl Printing House, ul. Warszawska 54, 87-148 Łysomice, tel. +48 566783478 


\section{Table of Contents}

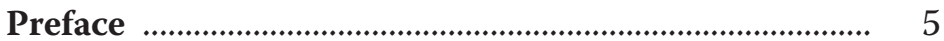

\section{Sri Lestari Wahyuningroem}

Democratic Transition Matters: Explaining

Transitional Justice in Indonesia

Imelda Masni Juniaty Sianipar, Arthuur Jeverson Maya

Populism in The Philippines and Human Rights 54

\section{Ade M. Wirasenjaya}

Neo-developmental State and Indonesia's Human

Right Problems in the Joko Widodo Era

\section{Gabriela Morawska-Stanecka}

Women Rights are Human Rights - why we Should Look Closely at the Situation in Asia?

\section{Ghias Aljundi}

The Arab Spring. The Syrian Autumn

\section{Renata Gałaj-Dempniak}

Human Rights in Asia: Practical Implementation on the Example of Japan 
Anna Adamus Muszyńska

Third-Gender Rights in Asia

\section{Antonio Stango}

Freedom of Religion and Minority Rights in China ....... 186

\section{Akihisa Matsuno}

The Decline of Freedom of Expression in Japan:

Political Interference and Blackmail

Ied Veda Sitepu, Lisa G. Kailola, Dikky Antonius

Right to Education: Revisiting Access for Students with Disabilities to Higher Education in Indonesia 


\section{Preface}

There is no doubt that human rights are universal and inherent to every human being regardless of colour, religion, opinion, wealth, origin, gender or sexual orientation. Nevertheless, many countries still refuse to recognise this fact and commit serious abuses of human rights. Yet the tragic experience of the Second World War proved that there is a direct link between respect for human rights and the maintenance of peace between states. Leaving human rights issues to internal competences of individual states was not a sufficient guarantee of their implementation. It therefore became necessary to create international, universal systems for the protection of human rights, namely, international law standards, effective mechanisms for their implementation and bodies. These arguments gave rise to such organisations as the United Nations, the Council of Europe, the Organisation for Security and Cooperation in Europe, the Organisation of American States, the African Union and the League of Arab States. Unfortunately, it has not yet been possible to establish a regional system for the protection of human rights in Asia. ASEAN, a political and economic organisation, has in recent years addressed the issue of human rights, nevertheless it can hardly be considered an effective defender of human rights. Apart from adopting several documents on human rights, it has not created any control mechanisms for respecting human rights. Human rights in Asia do not actually have a long tradition. They only took shape sometime in 
the $20^{\text {th }}$ century. Human rights in Asia have not often been the subject of political debate, as they are often regarded as a product of Western civilization, not very compatible with Asian culture. Thus, the problem of respect for human rights in Asia has been of interest to international human rights organisations for years.

The book entitled "Selected human rights issues in Asia", is the fruit of collaboration distinguished scholars and practitioners of human rights from Indonesia, Italy, Japan, Syria/ the United Kingdom and Poland who present various issues concerning respect for human rights in selected Asian countries. This publication is primarily addressed to scholars and professionals dealing not only with issues related to human rights protection, but also international security, international relations and those interested in the problems of Asian countries.

Sri Lestari Wahyuningroem addresses the important issue of democratic transition, explaining transitional justice in Indonesia. The fall of 32 years of authoritarian regime in Indonesia led by General Suharto, marked the beginning of a transition from an authoritarian regime to democracy, and made it possible for transitional justice agenda to be adopted by the state. In general, the adoption of these transitional justice measures was positive in terms of the promotion of state accountability and human rights protection. However, the implementation was deeply unsatisfactory and totally failed in fulfilling the objectives for truth and justice. Explaining such poor outcomes of transitional justice and human rights as resulting from the lack of the state's political willingness is unsatisfactory because it assumes the state is monolithic, ignoring the fact that during the transition and in the period of what most scholars referred to as con- 
solidation, state institutions and agents are willing to adopt transitional justice measures with different motivations and interests. Her paper departs from this doubt. She seeks to explain further and understand transitional justice as unfinished agenda in Indonesia's democracy by linking it with the nature of democratic transition that took place in the country since 1998.

Imelda Masni Juniaty Sianipar and Arthuur Jeverson Maya discuss the relationship between populism and human rights, which is perceived as a contradiction. They analyse it on the example of Philippines. The emergence of a populist leader, Rodrigo Duterte, devastated the human rights situation in the Philippines. Since being elected president in 2016, Duterte has committed a number of human rights violations, including the murder of drug dealers and addicts, media blocking, and attacking human rights defenders and so many others. The authors admit that public trust in leadership, the discursive construction of national threats, the lack of internal and external threats, and economic stability contribute to human rights abuses in the country.

Ade M Wirasenjaya tries to explain the revival of a developmental state's idea in development policies in Indonesia during the Joko Widodo era. The idea of a developmental state is a development paradigm carried out by the Suharto regime during the New Order era. As the author claims - during the new Order Era, the developmental state gave birth to an authoritative regime supported by military power. Meanwhile, during the Joko Widodo era, the developmental state grows together with the civilian regime with an oligarchic character. Both of these developmentalism eras bring significant implications for the emergence of human rights violations. 
Gabriela Morawska-Stanecka provides data on human rights and women rights violation in Pakistan, Indonesia and Iran. She concentrates on issues such as reproductive rights and gender equality, but also other aspects such as minority rights, where women and children from minorities suffer disproportionally more. She concludes, that more efforts should be put in working with local women rights advocates and that the problems raised by women are neither gender nor region restricted. They are global and that's the reason why general public and decision makers should look closely at Asia and the women struggle there gives researchers and politicians a perspective needed to truly understand the challenges faced by women everywhere.

Ghias Aljundi talks about the situation in Syria in the tenth anniversary of the Syrian revolution/war. After the period of oppression, fighting and bombardment, existence in Syria as it was before 2011 has disappeared. The vast majority of the infrastructure has been destroyed or is dysfunctional. In the author's opinion the country is on its knees, the oppressive regime continues with its repressive policies while at least four armies are intervening in the country. The economic situation is dire and Syrians find it extremely difficult to survive and to secure the minimum standard of living. Corruption has reached uncontrollable levels and those who criticise corruption, even among the regime's supporters, face detention and torture. Freedom of expression and media are also dire. Detention of activists and journalists continues without any legal basis. It does not seem to be that case that the situation in Syria will be changes. Assad is planning to re-run in the June 2021 so-called elections for another term in office.

Renata Gałaj talks about practical implementation of human rights on the example of Japan. The author claims 
that Japan lacks legislation prohibiting racial, ethnic, and religious discrimination as well as on the grounds of sexual orientation or gender identity. It also concerns people with disabilities. The government is also accused of discriminating against and acting to the detriment of the victims of the tsunami and the explosion of the Fukushima nuclear power plant, as well as those subjected to forced sterilization under the eugenic protection act in 1948-1996.

Anna Adamus Matuszyńska analyses the relationship between human rights and third-gender acceptance in Asia. Sex and gender there are two terms, which have particular significance in the contemporary world, rising attention as well as anger depending on who is concerned. Biological and cultural gender have been the subject of numerous studies and research for years. From the point of view of human rights, the most important thing is gender identity or the feeling of gender identity. That issue is essential due to individual and social identity, but at the same time difficult to describe (depending on the readiness of the respondents to make an open coming out), socially sensitive (there is still no society that fully accepts this social issue without any reservations) and still considered as controversial despite universal human rights, extensive research and the development of tolerance towards diversity.

Antonio Stango writes about Freedom of Religion and Minority Rights in China, where its officially registered 56 'nationalities', including the dominant Han population, however the People's Republic of China has been adopting policies varying from marginalization to assimilation, and in some cases to what some scholars argue that may be defined "cultural genocide". With the fast economic growth since the 1990s, the state has devoted huge resources to what it calls 
modernization of the theoretically autonomous regions, but has not cared of protecting minority rights. As for freedom of religion, policies have aimed to rigidly control the practitioners, with the Chinese Communist Party supervising a system of 'recognized religions' and repressing other groups of believers. The author focuses mostly on 'Mainland China, then refers to Taiwan as an example of a different way to deal with minorities, and mentions the situation of Hong Kong.

Then Akihisa Matsuno writes about the Decline of Freedom of Expression in Japan, political Interference and blackmail. He analyses the decline of freedom of expression in Japan during the past decade. I argue that the decline is the result of an increased political interference from the nationalist conservative administration and intensified campaigns by those who ally with it including its anonymous supporters who blackmail media or individuals. Although physical attacks such as assassinations have become rare in the past decade, threats and blackmail have continued. Media, journalists, academics, and activists who write critically about wartime atrocities such as the Nanjing massacre or comfort women or those who speak against legislation such as the latest security bills and the secret protection act that may undermine the constitutional pacifism receive various forms of pressure such as removal from influential posts, harassment, threats, or blackmail. Pressures are also put on their families. Finally, the article examines how freedom of expression for women is severely undermined by cyberbullying.

Ied Veda Sitepu, Lisa G. Kailola, Dikky Antonius discuss about the right of people with disability to higher education. The authors remind that education must be for all, not 
discriminative for every citizen of Indonesia as stated at the 1945 Constitution. In Indonesia, children with disabilities are given attention and they can access education in schools for the special children. Inclusive education means that every citizen with disability must stay in the same classroom with other students. Inclusive concept should also apply to higher education. People with disabilities should also be given the opportunity to study in tertiary level so that they can take more part in the community, in the labour market and maybe make important decisions for their interest and of others. Not too many institutions of higher learning in Indonesia are ready to admit them, however, due to prerequisite facilities that have to be completed by institutions before they can give access to people with disabilities; only a small number of higher education institutions that are ready but not for all kinds of disabilities. In their article they describe a general picture of higher education facilities for people with disabilities.

I encourage you to read the book. 



\section{Sri Lestari Wahyuningroem}

Universitas Pembangunan Nasional Veteran Jakarta

ORCID ID: https://orcid.org/0000-0003-3144-6120

\section{Democratic Transition Matters: Explaining Transitional Justice in Indonesia}

\section{Introduction}

Indonesia's political transition started in 1998 with the fall, after 32 years, of the authoritarian regime led by General Soeharto, following the economic crisis that hit the country and massive demonstrations that took place in Jakarta and elsewhere in the same year (Robison \& Hadiz, 2004; Hill, 1999; Aspinall, 2015; Robison, 2001). This change marked the beginning of a transition from an authoritarian regime to democracy, and made it possible for past human rights abuses committed during the authoritarian period to be acknowledged by the wider public.

After five successive presidents and four elections, there have been many attempts to bring about mechanisms for ensuring truth and justice with respect to past human rights abuses, and with regard to more recent abuses during or after the reform process. Indonesia is one of the many countries that has adopted more than one transitional justice mechanisms. At the beginning of the transition, as early as in August 1998, truth-seeking was pursued for multiple cases, while legal reform also took place. Both processes later 
led to human rights trials. In 2004, Indonesia finally passed the Law on Truth and Reconciliation. But the Truth and Reconciliation Commission (TRC) had not yet been established when the Constitutional Court annulled the Law in 2006.

In general, the adoption of transitional justice measures and human rights policies was positive in terms of the promotion of state accountability and human rights protection. However, some reserachers suggest that the implementation of these measures was deeply unsatisfactory Ehito, 2016, Linton, 2006; Juwana, 2003; Hadiprayitno, 2010, Suh, 2012, ICTJ and KontraS, 2011). I found these analyses helpful but ultimately unsatisfactory because they fail to explain why Indonesia produced poor outcomes in terms of substantive accountability and human rights promotion. Yet, all of these analyses share the same argument in explaining these failures: the lack of political will on the part of the state and ruling elite.

Explaining such poor outcomes of transitional justice and human rights as resulting from the lack of the state's political willingness is unsatisfactory because it assumes the state is monolithic, ignoring the fact that during the transition and in the period of what most scholars referred to as consolidation, state institutions and agents are willing to adopt transitional justice measures with different motivations and interests. This paper departs from this doubt. It seeks to explain further and understand transitional justice as unfinished agenda in Indonesia's democracy. In the paper, I argue in that state-sponsored transitional justice in Indonesia has been successful only in terms of procedure, and even then only problematically so, but a total failure in substance. This outcome resulted from the nature of the 
political transition in Indonesia from 1998 onwards. What features of democratisation in Indonesia produced these outcomes of transitional? What factors facilitated or hindered transitional justice? These are the questions I seek to answer in this paper.

The paper shows that Indonesia's transition involved a combination of a rupture, or replacement, style of transition and a compromise, or transplacement. The replacement features motivated the government and the political elite to agree to the adoption of transitional justice measures. In the period of transition, when it lacked political legitimacy, the new government needed transitional justice to distance itself from the image of the predecessor repressive regime and to gain public trust, both domestically and internationally. However, the transplacement nature of the political transition, which involved bargaining between elements of the old regime and reformers, contributed to the failure to achieve the objectives of transitional justice. To further reflect on this analysis, I will use the ad hoc human rights trials of 1999 Timor Leste's referendum and 1984 Tanjung Priok Massacre as cases. The trials, often refered as the paket ganda or 'double package' trials, were a response to international and domestic pressures for accountability. I will show in this paper that the processes of the trials, as part of the adoption and implementation of transitional justice measures, were highly dependent on the nature of Indonesia's political transition.

The first part of the paper will discuss the emergence and development of transitional justice in Indonesia starting from the beginning of political transition that took place in the country shortly after Suharto stepped down from his office. Then I will discuss factors that contributed to those 
outcomes of transitional justice which relate to the nature of political transition. I will apply this argument to explain the failures of the 'double package' trials in the third part of this paper. Lastly, I will end the paper with the conclusion.

\section{Transitional Justice in Indonesia: Its Emergence and Development}

The field of transitional justice study has taken shape over the last twenty years. In its simplest form, transitional justice, according to the 2004 report of the United Nation Secretary-General, is defined as "the full range of processes and mechanisms associated with a society's attempts to come to terms with a legacy of large-scale past abuses, in order to ensure accountability, serve justice and achieve reconciliation (UN Doc 2004: 3)."

Attempts to settle cases of past injustices can take place through various measures and mechanisms. The mechanisms most referred to in the literature are those that involve prosecution, truth-seeking, reparations and institutional reform in the form of lustration or vetting. Prosecution aims at redressing the suffering of victims, and to provide opportunities to establish or strengthen the judicial system and the rule of law in transitional countries. Such efforts also aim at reflecting a new set of social norms based on respect for human rights and can be a starting point for the process of reforming and building trust in government institutions (Van Zyl, 2005: 211).

Truth mechanisms include the creation of truth commissions - bodies that are tasked with uncovering what happened during human rights abuses - or other national 
and international efforts, such as major historical research or documentation of violence and victims of violence, and exhumations. State authorities often use truth-seeking in response to the limited effectiveness of international and domestic courts in dealing with past atrocities (Hayner 2000:27). In many contexts, truth comes together with reconciliation, because most experts believe reconciliation can only be achieved if the past suffering of victims is acknowledged.

Reparations policies consider the physical requirements of, or moral obligations to, the victims and survivors of abuse. Reparations can include economic compensation and non-material efforts including symbolic recognition such as state apologies to, and memorialisation of, victims. Unlike prosecutions, truth, and institutional reform, reparation mechanisms focus more on victims' experiences and needs.

Meanwhile, experts believe the reform of institutions that have histories of abusive behaviour, including the security forces and related institutions, is necessary in order to prevent recurrence of patterns of abuses and to establish a state-society relationship based on functioning and fair institutions. One concrete measure is to apply vetting as part of security sector reform. ${ }^{1}$

Globally, an increasing number of countries have adopted and implemented transitional justice mechanisms.

1 The term 'vetting' is often used interchangeably with other words such as 'lustration,' 'screening', 'administrative justice, and 'purging. One important distinction is that 'lustration' usually is the term used to refer to post-communist contexts, while purging is targeting people for their membership or affiliation with a group rather than their individual involvement in human rights violations. See Roger Duthie, "Introduction, in Alexander Mayer-Rieckh and Pablo de Grieff (eds), Justice as Prevention, Vetting Public Employees in Transitional Societies, (New York: Social Science Research Council), 2007, pp. 17-18. 
Sikkink and Payne (2014: 36-39) create datasets on various mechanisms of transitional justice around the world. Their data show a positive worldwide trend in state efforts to enforce accountability for human rights crimes. In the Asia-Pacific, Jeffrey and Kim (2014: 22-27) also show that the increasing number of countries have adopted transitional justice mechanisms since 1980. The dataset developed by Olsen, Payne, and Reiter (2010) shows that there is a growing trend for the countries in the Asia-Pacific to institute more than one mechanism. Out of 19 countries that had adopted transitional justice by 2009 , only six instituted just one mechanism. Others had implemented two or more mechanisms either simultaneously or sequentially. The most commonly used mechanisms in these countries trials, truth commissions, and amnesties.

Indonesia is one of the many countries that has adopted more than one transitional justice mechanisms. At the beginning of the transition, truth-seeking was pursued for multiple cases, while legal reform also took place. Both processes later led to human rights trials. President Habibie (1998-1999) set up inquiry teams on conflict in Aceh and on the rioting and violence that accompanied regime change in Jakarta during May 1998. Komnas HAM, as an autonomous state body, also set up a number of fact-finding teams aimed at revealing the truth about human rights abuses, including those that had occurred in East Timor, the 1984 Tanjung Priok massacre, the 1989 Talangsari massacre, and some other cases of recent and past abuses. Trials began under Abdurrahman Wahid's (1999-2001) presidency, including trials on mass violence during East Timor's 1999 referendum for independence. In 2004, Indonesia finally passed the Law on Truth and Reconciliation. However, the Truth and 
Reconciliation Commission (TRC) had not yet been established when the Constitutional Court annulled the Law in 2006. From that time, the central government took no more significant efforts to deal with or resolve cases of past abuses. Out of all mechanisms, law regulations that related to the adoption of human rights norms into local policies were mostly chosen during the early period of reform (1998-2004). Within this period, Komnas HAM had a significant role in promoting and maintaining the momentum for human rights accountability through inquiries (truth seeking initiatives), including for cases of past abuses under the Soeharto's rule (Setiawan, 2013; Lay et.at., 2002). Komnas HAM later also made a breakthrough, together with LPSK (Lembaga Perlindungan Saksi dan Korban, the Indonesian Witness and Victims' Protection Agency), in establishing a reparation scheme for the victims of past human rights abuses.

Other than Komnas HAM and its truth-seeking initiatives, state institutions also pursued other options related to transitional justice. The MPR (Majelis Permusyawaratan Rakyat, People's Consultative Assembly) - Indonesia's supreme law-making body - passed Resolution No. V in 2000, which later served as the foundation for other measures for transitional justice. The DPR (Dewan Perwakilan Rakyat, People's Representative Council) - Indonesia's parliament - also responded to the demands for human rights accountability and transitional justice by passing various laws and taking political decisions on some cases of human rights violations. For example, it passed Law No. 39 of 1999 on Human Rights and Law No. 26 of 2000 on Human Rights Courts. The judiciary was also active. The Supreme Court accommodated some demands that it deal with past abuse 
cases, especially the 1965-66 violence - when hundreds of thousands of leftists were massacred by the army and its allies - by issuing a letter to the president and parliament recommending that they acknowledge and rehabilitate the rights of the victims in 2003 (Mahkamah Agung, 2003) Meanwhile, the security sector, including the military and the police, also took positive moves toward institutional reform and accountability. There was a flurry of lawmaking and other initiatives in the early phase of the transition (1998-2001), but that the pace of transitional justice slowed dramatically after that.

In general, the adoption of transitional justice measures and human rights policies was positive in terms of the promotion of state accountability and human rights protection. However, some assessments suggest that the implementation of these measures was deeply unsatisfactory. Most observers believe that the implementation of these policies has been flawed in many ways, resulting in the "deficit" of justice and accountability (Juwana, 2003; Hadiprayitno, 2010) and even the "derailing" of transitional justice (ICTJ, 2010). The implication is that the situation of human rights protection has not improved (Juwana 2003), producing no effect in terms of protecting rights-holders (Hadiprayitno, 2010) or ending impunity (Linton, 2006). The transitional justice agenda, therefore, has been 'hijacked' by the new political elite in the Post-Soeharto period (Linton, 2006). Yet, all of these analyses share the same argument in explaining these failures: the lack of political will on the part of the state and the ruling elite.

Explaining such poor outcomes of transitional justice and human rights as resulting from the lack of the state's political willingness is unsatisfactory because it assumes the 
state is monolithic, ignoring the fact that during the transition and in the period of what most scholars referred to as consolidation, state institutions and agents are willing to adopt transitional justice measures with different motivations and interests. These interests often collided with one another. In fact, some leaders were well informed and highly motivated to settle cases of past human rights abuses. Individual leaders are thus an important factor in determining whether or not transitional justice measures were introduced. Beyond the leadership aspect, state and political institutions chose to adopt transitional justice policies and mechanisms in an attempt to distance themselves from the Soeharto regime. Learning from the "tactical concessions" adopted during Soeharto's time (see Jietschke, 1999), especially the establishment of Komnas HAM, these leaders viewed transitional justice as a concession that could be offered in order to gain political legitimacy in the new more democratic era, both from the international community and from the domestic public. I argue that the state and its leaders opted for and implemented transitional justice as a purely "tactical concession" without acknowledging the very reasons why violence had occurred. Tactical concession here refers to Risse and Sikkink's (1999) understanding of governments' rethoric response to pressure groups demanding adherence to particular norms, by underestimating the impacts of the changes or concessions they made (Risse and Sikkink, 1999: 66). Indonesia's transitional justice process was thus, from the start, politically superficial, as transitional justice was adopted only to respond domestic and international pressures for accountability of the repressive regime. 


\section{Explaining Transitional Justice: The Nature of the Democratic Transition}

With the flourishing of the 'third-wave' of democratisation since the 1980s, studies on transitions to democracy have acknowledged that nations undergoing transition faced dilemmas about whether to adopt a backward-looking focus on past injustice, by acknowledging the former authoritarian regime's role in past human rights abuses and trying to address these issues, or remain forward-looking and concentrate on rebuilding democratic institutions. Alhough most scholars of democratisation place emphasis on understanding the dynamics of the transitions themselves and the subsequent political consolidation, some also look at the problem of "settling accounts with the past", in O'Donnell and Schmitter's words (1986: 30), or "the torturer problem" as Huntington (1991: 209) puts it.

This torturer problem confronts democrats with a choice between burying the past in order to avoid political instability initiated by spoilers from the old regime, and the moral and ethical demands to confront the crimes of the repressive period. O'Donnell and Schmitter acknowledge that how leaders respond will significantly influence the emergence of the new political system. Failing to analyse the past, in their view, might prevent a society from reaching a consensus on what was wrong in its history and therefore might damage attempts to form new societal bonds. In dealing with these past abuses, they argue, the "worst of bad solutions would be to ignore the issue", and that the least worst strategy, based on ethical and political considerations, is to hold trials for the wrongdoers (O’Donnell and Schmitter, 1995: 59). 
In dealing with the past, one of the factors that has great influence on the adoption of transitional justice measures is the nature of the transition. Barahona de Brito, Gonzalez Enriquez, and Aguilar (2001: 11-12) argue that transitional justice choices are strongly related to the types of political transitions undertaken. The more a transition entails defeat or total break with the old authoritarian elite and those responsible for human rights violations, the more possible it is for the incoming elite to choose thoroughgoing transitional justice policies. Accordingly, they argue that variations in policies and outcomes of transitional justice depend on where a country is located on a democratic transition spectrum. At one end, there are transitions by rupture that occur after a foreign intervention, revolution or civil war that leads to the military defeat or sudden overthrow of dictatorial forces. At the other end of the spectrum, there are negotiated, 'pacted', reform-oriented types of transition. In this type of transition, outgoing regime authorities retain some power and influence, and thus the incoming elite hoping to form a new democratic regime have to negotiate change with the old guard.

There is abundant literature in political science that tries to capture the types of democratic transitions. Huntington (1991), for example, in his widely quoted book on third wave democratisation, categorises transitions into three types, based on his analysis of thirty-five third wave democratisations. These types are transformation, replacement, and transplacement (Huntington, 1991: 124-125). Transformation is a type of transition where elements of the authoritarian regime spearhead reforms that lead to a democratic system. Such a decision typically requires the government to be stronger than the opposition. Transformations are 
gradual, top-down processes of regime change. The replacement type of transition, in contrast, does not happen by the willingness and decision of the authoritarian government. In the lead up to such a change, most of the standpatters-or the hardliner elements that support the regime-deny any need for change, while reformers in the government are either weak or non-existent. Democratisation occurs as the result of strengthened opposition that overthrows the regime. This form of regime change is sudden and initiated from below. Lastly, the transplacement type is when there is a balance between standpatters and reformers within the authoritarian government that makes the government willing to negotiate on regime change with the opposition. The opposition is strong enough to prevail over anti-democratic radicals, but not strong enough to overthrow the government by themselves. As a result, democratisation happens as a result of processes of negotiation and compromise.

While Huntington's categories are useful for my research, Indonesia's transition does not match exactly any of these types; instead, it is a mixture of replacement and transplacement. This mixed transition relates to the nature of Soeharto's regime that, as proposed by Aspinall (2005), combining sultanistic with strongly authoritarian features. Such a combination resulted in democratic transition that occurred though considerable street disorder with a "dramatic breakthrough" and the sudden resignation of Soeharto in May 1998, and, at the same time, showed "a high degree of continuity between the new democratic policy and those of the authoritarian past" (Aspinall, 2005: 269). The economic crisis during the last year of the New Order regime instigated mass protest and social unrest. Both the standpatters and weak reformers in the government lost 
their ability to manoeuvre. Violence was used to repress opposition groups, especially with the enforced disappearance of a number of anti-Soeharto activists (Collins, 2007).

Meanwhile, opposition groups strengthened in 1998 and mobilised popular protests, demanding Soeharto step down and the government to undertake reforms. In May 1998, the government leaders, most notably Soeharto himself, invited elements from the opposition to negotiate the direction of the regime change. Most of these opposition leaders refused to deal with him, however, and his regime collapsed. After Soeharto stepped down on 21 May 1998, a series of compromises took place through several stages. The first stage involved the recruitment of a new elite, who were critical of the New Order in old political institutions. The Golkar (Golongan Karya, Party of the Functional Groups), the political party of the New Order regime, for example, made a drastic and sudden change in its membership in MPR (and DPR) to satisfy public demands for total reform (reformasi total). The second stage was the establishment of new political institutions, including various new political parties before the first post-Soeharto election in 1999. The third stage took place after the 1999 election, when most of the key political forces and leaders who were involved in the 1998 reform movement participated in the new power structure by taking senior governmental posts. At the same time, however, old forces - such as those representing the Golkar and the military - were never entirely excluded from the power structures of the new "Reformasi Order". The new regime was fundamentally a product of political compromise.

The mixed nature of the transition affected the transitional justice measures adopted in the period of democ- 
ratisation. The elements of regime change that resembled replacement pushed successive governments to adopt transitional justice in order for them to gain legitimacy and create distance between themselves and the New Order regime. However, the transplacement features, involving the accommodation of elements of the New Order in formal politics, led to the failure of transitional justice outcomes at the implementation level. When the political elite started to consolidate and gain legitimacy through elections, transitional justice disappeared from the political agenda, and past injustices were regarded as being irrelevant. The era of progress in transitional justice was over.

The roles of the opposition is central to my analysis. In Indonesia's case, it was the opposition that generated the transitional justice agenda. However, the opposition was not monolithic, and thus there was never a consensus on transitional justice among the opposition groups. Aspinall's (2005) outlines the types of opposition that operated during Soeharto's last years of government. He categorises them into the mobilisational opposition, semi-opposition, alegal opposition, and proto-opposition. The mobilisational opposition included groups that explicitly expressed demands to replace the regime with another system (Aspinall, 2005: 6). In doing so, these groups - such as students - tried to organise and mobilise a mass support base. The semi-opposition refers to those who participated in the formal structures of the regime and were associated with "work-from-within" strategies of political reform. This group was more likely to engage in "compromise, partial and often unclear goals, and the utilization of regime language and ideological formulas to argue for political change" (Aspinall, 2005: 6-7). It involved the supporters of the legal political parties, such as 
the PDI (Partai Demokrasi Indonesia, Indonesia Democracy Party) and the mass organisations, such as major Islamic organisations like Nahdlatul Ulama (NU) and Muhammadiyah, which continued to command the loyalties of millions of Indonesians throughout the New Order period. The third group, the alegal opposition, was more fundamentally critical than the semi-opposition. It was marked by dissidence: the early participants or supporters of the regime, who later made moral appeals or calls for the regime to initiate reform, without wanting the society to take action or organise their supporters behind a reform platform. Lastly, the proto-opposition included civil society organisations. These groups had limited and partial aims but were independent from the state structures. Even though they pursued limited aims, civil society organisations were a refuge for oppositional impulses during repressive conditions, and thus could harbour individuals who wished to transform the authoritarian regime.

Transitional justice was, above all, an agenda promoted by proto-opposition, notably by non-governmental organistions (NGOs) and other civil society groups, but it was also adopted by semi-opposition actors such as those associated with political parties. When the semi-opposition eventually managed to get into the new state structures after the 1999 election, they supported transitional justice measures. Transitional justice became a central part of the new post-Soeharto political order, agreed to by everyone, including elements from the outgoing regime.

Later in the consolidation period, the dividing line between the forces of the old regime and new democrats began to break down. Successive governments accommodated and absorbed all major political forces, producing remark- 
able stability in the Indonesian transition (Aspinall, 2010; Slater, 2004, 2006). Such stability was also successful in drawing in potential spoilers. "Spoilers have been accommodated and absorbed into the system rather than excluded from it, producing a trade-off between democratic success and democratic quality" (Aspinall, 2010: 21).

Facing massive pressure for political change after the fall of Soeharto, both the new and old elites had to fulfil the demands for state accountability to gain public legitimacy and international support. They needed to break from the New Order. Transitional justice became a useful tool for convincing both the national and international public that change was real. The reconsolidation of the elites, however, meant that transitional justice was no longer needed.

\section{The Law on Human Rights Trials and the 'Double Package' Trials}

A month after he came to office, President Habibie announced unexpectedly in a cabinet meeting on 9 June 1998 that he would give the East Timorese two options to resolve their tensions with the Indonesian government: extended autonomy within the Indonesian state or becoming independent (Merdeka.com, 30 June 2016). Even though Ali Alatas, the then Minister of Foreign Affairs, had lobbied the UN and Portugal for an extended period of special autonomy before the referendum, Habibie insisted on holding it immediately with the two options. ${ }^{2}$ The referendum eventu-

2 See the interview with Ali Alatas in Tempo 3 March 2003, p. 186. Alatas revealed that Habibie openly rejected the option to hold a referendum with a 10-15 years transition period in East Timor. His rejection was in response especially to various criticism from pro-independence groups 
ally took place on August 1999, and the result was a shock to many Indonesians, especially the political elite: almost eighty percent of the East Timorese decided to separate from Indonesia and have their own independent state.

What followed after the referendum was even more shocking, not only to Indonesia's elite and public but especially to the international community. Groups of pro-integration militias who were trained by the Indonesian military engaged in massive violence in East Timor, resulting in numerous towns burnt and thousands of casualties. The UN immediately called for a special session on 23-27 September 1999, and issued Resolution 1999/S-4/1 demanding the Indonesian government to bring those who committed wrongdoings to account and provide security for locals as well as international parties, including the UN. Furthermore, the resolution demanded the UN Secretary General form a special commission of inquiry consisting of international experts to investigate the violence that had taken place in East Timor since 27 January 1999. In the session, Indonesia's representative in Geneva explained that the government intended to establish a special inquiry team called the KPP HAM Timtim (Komisi Penyelidik Pelanggaran HAM di Timor Timur, Inquiry Team on Human Rights Abuses in East Timor ). The team was later

as well as to a letter sent by Australia's Prime Minister John Howard that urged Habibie to choose the French solution to the New Caledonia issue by giving the East Timorese the option of independence after a period of 10 years of transition. Initially, the offer was to have extended special autonomy for East Timor, which was announced on 18 June 1998. Only on 27 January 1999, after Indonesia's Minister of Foreign Affairs lobbied the UN and Portugal, did the government under Habibie decide on two options: special autonomy or independence for East Timor. According to Alatas, in the meeting almost everyone was optimistic that the East Timorese would choose to stay with Indonesia, convinced by reports from the intelligence bodies. 
formalised by Komnas HAM under Komnas HAM Decree No. 770/TUA/IX/1999.

Habibie further responded by establishing a Perpu No. 1 year 1999 on Human Rights Courts, dated October 1999. The purpose was to establish a new category of courts that could try cases of gross breaches of human rights. The parliament rejected the Perpu, and declared that it did not comprehensively list the types of crimes that could be categorised as 'gross human rights abuses'. It also did not regulate in detail the human rights court's processes, and the parliament stated that it should not have retroactive effect. As international pressure for prosecuting the Indonesian military was mounting, Habibie's replacement as president Abdurrahman Wahid, through his minister of Law and $\mathrm{Hu}-$ man Rights Yusril Ihza Mahendra, prepared a draft Bill on Human Rights Court to replace the Perpu and submitted it to the parliament on April 2000.

The draft law was rapidly discussed and then passed by Commission 3 (mandated for legislation related to law, human rights and security) of the parliament on 23 November 2000 as Law No. 26/2000 on Human Rights Courts. The draft Law partially adopted the wording used to outline the mandate and powers of the International Criminal Court (ICC) under the 1998 Rome Statute, particularly Articles 5 to 8 of the Statute. Initially, the DPR (Dewan Perwakilan Rakyat, The People's Representative Council) avoided drawing on international precedents in the early discussions of the draft. Only when militia members in Atambua, West Timor, killed three UN humanitarian workers on 6 September 2000, and the UN insisted on the establishment of an international tribunal because international law was violated, did both government representatives and committee mem- 
bers make reference to the Rome Statute of International Criminal Court (ICC).

Despite some problematic clauses adopted in the Law, under international and domestic pressure, the Law accommodated cases of past human rights abuses and some provisions from the Rome Statute, including the acknowledgement of two serious crimes and their elements, and reparations for the victims of violence. Overall, the law represented a high-water tide mark in post-Soeharto legislative action on transitional justice. It was a major concession to demands for greater state accountability, but one that was also marred by major compromises, including the exclusion of war crimes and the requirement that human rights court can only take place by recommendation of the parliament. This latter provision means bringing the rule of law into politics.

The Law gave way to the establishment of the ad hoc trial on abuses in East Timor in 2002, followed by the ad hoc Tanjung Priok trial in 2004. With the East Timor's trials, based on the Kejagung's indictments, 12 trials were held from March 2002. Out of 18 defendants, only six were convicted and received sentences ranging from threeto 10 years. Later, all were acquitted on appeal. The trials did not establish clear command responsibility at the institutional level and strengthened the opinion promoted by many Indonesian officials that violence in East Timor was a classic case of amok or spontaneous clashes between unorganised groups in the society. The highest-ranking person held responsible was the commander (Pangdam Udayana) of the military region of which East Timor was a part, Major General Adam Damiri, who, in August 2003, was convicted for violence in Licquisa Church in April 1999 and Covalima Church in 
September 1999. Like the rest, he was acquitted on appeal in the following year. We return to the reasons for these failures later in the chapter.

Meanwhile, the Tanjung Priok trials, an ad hoc human rights trial concerning the massacre which took place in September 1984 in Tanjung Priok area, North Jakarta against muslim communities, were held and all 14 suspects were found guilty and sentenced to between two and 10 years in prison. Most of those sentenced were low-ranking soldiers. However, only two officers were sentenced: Rudolf Butar Butar, the former Commander of North Jakarta Military District, and Sutrisno Mascung, the former Commander of Group III of VI Yon Arhanudse (Batalyon Artileri Pertahanan Udara Sedang, Middle Air Defence Artillery Batallion). Both of them appealed to a higher court and were acquitted, as were all the other defendants

Why did these trials take place, despite the significant obstacles in their way that includes intimidation against witnesses, victims, and judges, and the partialities of the prosecutors to the military defendants? Sulistyanto (2007) argues that a coalition of actors within the civil society demanding the investigation of past abuses exercised such pressure that the new political elite had little choice but hold these trials. This idea, in my assessment, is partly true. In both the East Timor and Tanjung Priok cases, a strong coalition of human rights groups, victims' rights groups, and international advocacy networks played a significant role in articulating and pressuring the Indonesian government to take accountability measures. In the East Timor case, the most powerful coalition united human rights NGOs in Indonesia and East Timor, international NGOs and UN. In the Tanjung Priok case, the victims had already organised themselves sporadi- 
cally before 1998. When Soeharto's regime collapsed, prominent human rights figures, such as the late Munir, started to approach and mobilise them to help them seek redress for the abuses they had experienced. Victims also allied themselves with other elements of the civil society, especially those rooted in Islamic politics and social organisations.

Even though these civil society elements played a major role in pressuring the government to launch prosecutions, other significant factors also influenced the adoption of this mechanism. In line with my main argument about the conditions facilitating transitional justice in Indonesia's democratisation, these factors derived from the nature of Indonesia's transition. As previously argued, one aspect of Indonesia's regime change was a sudden legitimacy crisis of the old ruling elite. This crisis potentially limited the opportunities for individuals connected with the New Order to attain positions of authority in the new political system. One way for such figures to survive politically was to improvise and adjust to public demands, including demands for human rights accountability. Try Sutrisno, Wiranto, and other high-ranking officers involved in the East Timor and Tanjung Priok incidents all joined the competition for political positions, both in the executive (positions in cabinet) and in parliament. Senior military generals, such as Wiranto and Prabowo, took part in leadership competition in the Golkar in 2004. Later, they formed their own political parties. Other senior generals took the same path by establishing and chairing new political parties, including Try Sutrisno and Susilo Bambang Yudhoyono, and ran for political positions in elections.

As part of this process of political adaptation, senior military officers adjusted to accountability mechanisms, even ostensibly far-reaching ones such as the trials on East Timor 
and Tanjung Priok. During the investigation and trials, even though there was plenty of evidence that the military was trying to influence and intervene in the trial processes, what many researchers did not discuss is the fact that highranking commanding officers were mostly accommodating to the processes. Albert Hasibuan, the team leader of KPP HAM on East Timor, explained that initially the military tried to stop the processes, but later on, they became cooperative, including Wiranto, who is currently the Coordinating Miniter for Politics, Law and Security under President Joko Widodo's cabinet. Wiranto was held responsible because he held command responsibility then (interview with Albert Hasibuan in Jakarta, 2 May 2012).

Another factor influencing the trials was the confluence of interests, even a temporary coalition, between civil society actors, such as human rights groups and other NGOs, and the new emerging political elite, many of whom had backgrounds in the 'semi-opposition' during the late Soeharto period. This coalition also occurred in the context of the deep crisis of legitimacy of the Soeharto's regime. Many of the new elite - for example, the leading members of political parties - were themselves engaged in the race to gain political legitimacy and public support and wanted to distance themselves from the New Order and its practices. This short-term goal explains the new elite's willingness to take a stand against impunity and to support popular demands for human rights accountability - notably in the case of the the Tanjung Priok case. The overwhelming support from various political forces to re-open the case and establish an ad hoc court points to cooperation between wideranging coalitions, many members were brought together by a shared Islamic identity. 
A major factor in the success of the Tanjung Priok was the support the effort gained from members of the political elite. One of the reasons for that support is that several key activists and former political prisoners involved had in fact been close to the New Order. Although they ended up being repressed, they were not politically distant from the regime. Amir Biki, for instance, was one of the activists in a group commonly known the Angkatan '66, of the 1966 generation that had protested against Soekarno and the communist party in 1966. They subsequently formed the Forkot 66 (Communication and Study Forum, Forum Studi dan Komunikasi Angkatan '66) in which Biki also played the prominent role. Biki and some Muslim activists eventually became involved in the PPP, even though he maintained good connections with various official networks, including the military. However, he became critical of Soeharto's New Order from the early 1980s, at the same time that the regime itself was becoming increasingly suspicious of Islamic politics (interview with Beni Biki in Jakarta, 16 May 2012).

Meanwhile, the massacre in 1984, as mentioned above, led to the arrest of other well-known figures, including AM Fatwa, Abdul Qadir Jaelani and Syarifien Maloko. At the time of his arrest and trial, Fatwa was the secretary of the Petisi 50 dissident group headed by Ali Sadikin. The group released a statement on 17 September 1984, only five days after the incident in Tanjung Priok, criticising Soeharto's repression of Islamic groups. Jaelani was a Muslim preacher who was outspoken in his criticism of Soeharto and Pancasila ideology. Maloko gave a short speech on the day of the massacre but managed to escape and hide in Merak for more than a year before he was also arrested and jailed. The 
which three of them, together with a few others, were sentenced to between 10 and 16 years in jail.

After the New Order collapsed, and signifying the political transformation of opposition groups, all three joined new political parties established after 1998. Fatwa joined the PAN while Jaelani and Maloko joined the PBB. After the 1999 election, both Fatwa and Jaelani became members of parliament. Maloko was elected an MP in the Jakarta provincial parliament. The success of the movement for the Tanjung Priok trials was largely due to the mobilisation of support within parliament by politicians such as Jaelani and Fatwa and their supporters. For example, Beni Biki explained that the Tanjung Priok case was initially not included in the agenda for the DPR general session in 1999. However, with the help of the PBB politician Hamdan Zoelva, Beni managed to fulfil the requirement of having at least 40 MPs provide their signatures to support the inclusion of the case in the agenda (interview with Beni Biki in Jakarta, 16 May 2012). The PBB and many of its prominent members, including Hamdan Zoelva and Yusril Ihza Mahendra, were involved in the early investigation of, and advocacy on, the case with victims and human rights groups.

At the same time, many members of the PAN - which was linked to the modernist Islamic organisation Muhammadiyah, which in turn had connections with many affected by the post-Priok repression - also sympathised. The PAN's leader Amien Rais made public appearances and gave statements, demanding the government take responsibility for the violence. Likewise, another prominent Islamic party, the PPP, also strongly supported the coalition since Amir Biki was its cadre and activist. Other Islamic organisations, such as DDII and the newly established mass organisation 
FURKON (Forum Umat Islam Penegak Keadilan dan Konstitusi, Muslim Forum of Justice and Constitution Enforcement), led by another of Amir Biki's brothers, Faisal, also took part in the coalition. ${ }^{3}$ All in all, there was strong political support for action on the Tanjung Priok case, including from many well-connected actors. It helped that the case became a major focus of various Islamic movements and organisations.

Unlike the Tanjung Priok case, there was relatively little organisation and mobilisation around the East Timor case. Partly for this reason, investigations into abuses in East Timor, failed to gain the support of most of the Indonesian political elite. As discussed earlier, the international community and Western states were instead the main actors demanding accountability from the Indonesian government for what it had done in East Timor. On the Indonesian side, there was some lobbying and campaigning for trials, but most of this was done by human rights groups such as ELSAM and KontraS, as well as by some individuals and organisations who were part of the more radical fringe of student and mass-movement politics (these included some individuals and organisations who had close connections with the PRD). Although the national media regularly reported on developments in the investigations and trials, the Indonesian public and politicians were not well informed about the gross human rights abuses that had occurred in East Timor. For the Indonesian public, the issue was more

3 Faisal and his organisation, along with other militant organisations, received funding from the military, led by Wiranto as Habibie's Military Chief and Kivlan Zen as Army Strategic Reserve Command (Kostrad) chief of staff, to establish a civilian security guard or Pamswakarsa to 'secure' the Special General Session of MPR in 1998 against student protestors and others. See the Jakarta Post, June 28, 2004. 
about the inability of Habibie's government to keep East Timor as part of the Indonesian state. There was also considerable hostility to foreign intervention in what was considered a domestic affair.

This hostility to international pressure continued even after the trials in Indonesia were over. On 24 February 2003, while the trials were taking place in Indonesia, the SCU established under Kejagung in Timor Leste (the formal name of the new state) released an indictment to the Dili Court, requesting a warrant against eight Indonesian military officials for crimes against humanity committed at the time of the referendum. Some international and national organisations welcomed this indictment because previously the SCU had only indicted militia groups in Timor Leste. However, the fact that an institution under the political jurisdiction of the Timor Leste's government released the indictment made the it ineffective in pressuring the Indonesian government and its military officials to comply. ${ }^{4}$ Kiki Syahnakri, the Commander of Martial Law during the referendum said, "We will not consider the call, because the national courts dealing with the Timor Timur case have not yet completed their work." (Direito, 2003: 2). Likewise, Wiranto refused to

4 There was a controversy around the indictment by the Serious Crimes Unit. The controversy was around who actually developed the indictment. The UN spoke person Fred Eckhard in New York stated in 25 February 2002 that Timor Leste's Attorney General's Office (AGO) released the indictment, and the UN involved with advisory assistance. However, the indictment could be traced back to the time when the SCU was still placed under UNTAET. SCU was established by UN Resolution No 1272 in October 1999. Its mandate was to investigate serious crimes that took place around the referendum. When UNTAET was finishing, UNMISET (UN Mission in East Timor) was established and SCU was placed under the new body. When the Republic of Democratic Timor Leste was formally established, SCU was placed under AGO, but still worked under UN supervision and resources. 
respond to the indictment and denied the charges against him. He claimed that it was an attempt at character assassination by the UN (Liputan6, 8 February 2015). The Indonesian government, represented by the Minister of Foreign Affairs Hassan Wirayuda, also rejected the indictment on the basis that it violated Indonesia's national jurisdiction. The Indonesian Attorney General was reluctant to follow up. In fact, it was not only the Indonesian government which felt disinclined to hold such a tribunal, but also Timor Leste's government did not make it a priority, believing it could potentially damage bilateral relations between the two countries. In an interview with the BBC, Xanana Gusmao, former Fretilin leader who was imprisoned by the Indonesian government and subsequently became Timor Leste's president said that "we have enormous challenges, we will not forget but it must not be our priority" (BBC interview transcript, 10 October 2001).

As international pressure to establish a tribunal mounted, following the failure of the Indonesian ad hoc courts to punish Indonesian military officials, the two governments came up with a proposal to set up a bilateral truth commission called the Commission for Truth and Friendship (CTF). Again, to the larger public in Indonesia, this was not a priority issue and it therefore gained very little attention from politicians. The Indonesian Foreign Ministry was in charge of the process of the establishment of the Commission.

\section{Conclusion}

This paper shows that the failures of state-sponsored transitional justice in Indonesia has a strong link with the nature 
of democratic transition that took place in the country from 1998 onwards. Borrowing from Samuel Huntington's typology, I argued that Indonesia's political transition combined elements of both replacement and transplacement types of transition.

The replacement type regime change occurs when an authoritarian regime collapses or is overthrown and replaced by a successor democratic political order. In Indonesia's case, this element of regime change was obvious in the sudden collapse of the New Order's authority in the early months of 1998, and the inability of the leading elements in the New Order government to overcome the multiple national crises Indonesia was experiencing and regain their former domestic political legitimacy. Their inability to manoeuvre in the face of this crisis left them with reduced power to resist calls for state accountability in various spheres, including human rights. The adoption of transitional justice measures to deal with the human rights legacy of the New Order was a result. Not only could former generals, Golkar politicians and other elements of the old regime regain public confidence by supporting the adoption of transitional justice measures, but by doing so, they were able to distance themselves from Soeharto's regime. In other words, transitional justice was largely a tactical concession for many important political actors. It did not reflect deep normative transformation or the adoption of a new philosophical outlook on the part of man key actors authorising the new transitional justice framework. While this context helped to facilitate the adoption of transitional justice measures, it also helped inject weaknesses into them.

If replacement regime changes are sudden, transplacements tend to take place more gradually, and involve pro- 
tracted bargaining between elements of the old regime and the rising elites of the new democratic order. Especially once Indonesia's new 'Reformasi Order' began to settle into place, more or less coinciding with the election of a new parliament and the appointment of Abdurrahman Wahid as president in 1999, Indonesia's transition gradually to resemble transplacement. A new pro-democracy political elite was gaining influence rapidly, and demanding reforms in various sectors of politics and governance, but from the the beginning, these reformers shaped the direction of the transition in cooperation with elements of the old regime. Negotiations between new and old elements of the political elite were constantly taking place on all aspects of decisionmaking, including the design and implementation of transitional justice measures. I thus argued in this paper that the problems that arose in the implementation and outcomes of transitional justice were not merely about the lack of political will on the part of state leaders - an attitude which is common among human rights advocates in Indonesia - but are better viewed as being products of this constant negotiation of power at the elite level. Overall, justice objectives were compromised in the interests of achieving reconciliation among the political elite.

I demonstrate such analysis in explaining the establishment and implementation of ad hoc human rights trials for the 1999 violence in East Timor and the 1984 Tanjung Priok massacre. The trials were the government's response to international and domestic pressures for human rights accountability. Habibie's and Wahid's response to the international call for the Indonesian government to take responsibility for the serious crimes that took place in East Timor during and after the 1999 referendum stimulated demands 
domestically for a similar response to other cases of past abuses under Soeharto's regime. The victims of the the 1984 massacre garnered particular sympathy from the new political elite because it involved and implicated influential figures who had been engaged in the semi-opposition under the New Order regime.

Even though one trial was a response to international pressure and the other was conditioned by domestic pressures, there was no significant difference in terms of implementation and outcomes. Both trials suffered legal flaws, and were politically influenced to produce outcomes that mostly benefited the perpetrators rather than delivering justice for the victims. Even so, the trials served certain purposes for the government. They helped it to gain support and legitimacy from both the public and from the international community, and helped it to manage opposition within key political institutions, especially in the parliament.

Both trials were partially successful in procedural terms, but they failed to provide justice and truth for the victims. Moreover, they ultimately reinforced impunity, and high ranking military personnel responsible for the past crimes were found to be innocent.

\section{Bibliography}

Abidin, Zainal, Pengadilan Hak Asasi Manusia di Indonesia, Jakarta 2007.

Akhavan, Payam, Beyond Impunity: Can International Criminal Justice Prevent Future Atrocities?, "The American Journal of International Law" 2001, 95, No. 1. Akmaliah, Wahyudi, Islah Sebagai Dalih: Studi Kasus Pe- 
nyelesaian Konflik Peristiwa Tanjung Priok (1984) dan Talang Sari (1989) Pasca Rejim Orde Baru, "Jurnal Masyarakat \& Budaya" 2014, 16, No. 1.

Amnesty International, Amnesty International Report 1997

- Indonesia, 1 January 1997, available at: http://www.refworld.org/docid/3ae6aa0160.html.

Aspinall E., Indonesia, [in:] Revolutionary and Dissident Movements of the World ( $4^{\text {th }}$ ed.), ed. B. Szajkowski, Great Britain 2004.

Aspinall E., "Transformation of Civil Society and Democratic Breakthrough." Civil society and political change in Asia: Expanding and contracting democratic space (2004): 61-96.

Aspinall E., Opposing Suharto: Compromise, Resistance, and Regime Change in Indonesia, Stanford 2005.

Aspinall E., Indonesia in 2009: Democratic Triumphs and Trials, "Southeast Asian Affairs" 2010, No. 1.

Aspinall E., The Irony of Success, "Journal of Democracy" 2010, 21, No. 2.

Aspinall E., The Surprising Democratic Behemoth: Indonesia in Comparative Asian Perspective, "The Journal of Asian Studies" 2015, 74, No. 4.

Aspinall E., Greg Fealy G., Local Power E Politics In Indonesia: Decentralisation \& Democratisation, ISEAS-Yusof Ishak Institute, 2003.

Aspinall E., Fajran Zain, Transitional Justice Delayed in Aceh, Indonesia, [in:] Renee Jeffrey, Hun Joon Kim, Transitional Justice in the Asia-Pacific, Cambridge 2013.

Burns P., The Post Priok Trials: Religious Principles and Legal Issues, "Indonesia" 1989, 47.

Cassese A., On the Current Trends towards Criminal Prosecution and Punishment of Breaches of International 
Humanitarian Law, "European Journal of International Law” 1998, 9, No. 1.

Cassese A., Reflections on International Criminal Justice, “The Modern Law Review” 1998, 61, No. 1.

Komisi untuk Penerimaan, Kebenaran, dan Rekonsiliasi, Chega! No More, Stop, Enough, Dili 2006.

Cohen D., Seeking Justice on the Cheap: Is the East Timor Tribunal Really a Model for the Future?, "Asia Pasific Issue" 2002, No. 61, https://www.eastwestcenter.org/system/ $\mathrm{tdf} /$ private/api061.pdf?file $=1 \&$ type $=$ node\&id $=31885$.

Cohen D., Intended to Fail: The Trials Before the Ad Hoc Human Rights Court in Jakarta. New York: International Center for Transitional Justice, 2003.

Dancy G., Kim H., Wiebelhaus-Brahm E., The Turn to Truth: Trends in Truth Commission Experimentation, "Journal of Human Rights" 2010, 9, No. 1.

De Brito, Alexandra Barahona, Carmen González Enríquez, and Paloma Aguilar (eds.), The Politics of Memory: Transitional Justice in Democratizing Societies, New York 2001.

ELSAM. Progress Report I on Monitoring of Tanjung Priok Trials, 2003.

ELSAM. Final Progress Report Pengadilan HAM Tanjung Priok: Gagal Melakukan Penuntutan yang Efektif, Jakarta 2004a.

ELSAM. Preliminary Conclusive Report Pengadilan Hak Asasi Manusia Ad Hoc Kasus Tanjung Priok. Jakarta 2004b.

ELSAM. Tutup Buku dengan Transitional Justice? Menutup Lembaran Hak Asasi Manusia 1999-2004 dan Membuka Lembaran Baru 2005, Jakarta 2005.

ELSAM. Ketika Prinsip Kepastian Hukum Menghakimi 
Konstitusionalitas Penyelesaian Pelanggaran HAM Masa Lalu: Pandangan Kritis atas Putusan Mahkamah Konstitusi dan Implikasinya bagi Penyelesaian Pelanggaran HAM, Jakarta 2006.

Finnemore M., Sikkink K., International Norm Dynamics and Political Change, "International organization" 1998, 52, No. 4.

Forrester G., May R.J. (eds.), The Fall of Soeharto, New York 1998.

Glasius M., Foreign Policy on Human Rights: Its Influence on Indonesia under Soeharto, Antwerp 1999.

Glasius M., Foreign Policy on Human Rights: Its Influence on Indonesia under Soeharto, "School of Human Rights Research" 1999, Vol. 4. Intersentia.

Habibie B.J., Detik-Detik yang Menentukan: Jalan Panjang Indonesia Menuju Demokrasi, Jakarta 2006.

Hadiprayitno, Irene Istiningsih, Defensive Enforcement: $\mathrm{Hu}$ man rights in Indonesia, "Human Rights Review" 2010, 11, No. 3.

Hadiprayitno, Irene Istiningsih, Food Security and Human Rights in Indonesia, "Development in Practice" 2010, 20, No. 1.

Hadiwinata B.S. The Politics of NGOs in Indonesia: Developing Democracy and Managing a Movement, London 2003. Hadiz, Vedi., Dinamika Kekuasaan: Ekonomi Politik Indonesia Pasca-Soeharto, Jakarta 2005.

Hasibuan A., Lubis T.M., Nababan A., Dillon H.S., Irsan K., Katjasungkana N., Munir, Ringkasan Eksekutif Laporan Komisi Penyelidikan Pelanggaran Hak Asasi Manusia di Timor Timur, Timor Timur 2000.

Hayner P.B., Unspeakable Truths: Facing The Challenge of Truth Commissions, New York 2001. 
Hayner P.B., Unspeakable Truth: Transitional Justice and Challenge of Truth Commissions $2^{\text {nd }}$ Editions, New York 2011.

Hazan P., Measuring the Impact of Punishment and Forgiveness: A Framework for Evaluating Transitional Justice, "International Review of the Red Cross" 2006, 88, No. 861.

Huntington, Samuel. P. The Third Wave: Democratisation in the Late Twentieth Century. Oklahoma 1991.

International Crisis Group. Resolving Timor Leste's Crisis (Vol. 120), Brussels 2006.

International Center for Transitional Justice, \& Kontra S. Derailed: Transitional Justice in Indonesia Since the Fall of Soeharto, New York 2011.

International Criminal Court. Rome Statute of International Criminal Court (1998). Retrieved from >http://legal. un.org/icc/statute/99_corr/cstatute.htm<.

International Tribunal for the Prosecution of Persons Responsible for Serious Violations of International $\mathrm{Hu}$ manitarian Law Committed in the Territory of the former Yugoslavia since 1991. Rules of Procedure and Evidence (2015). Retrieved from http://www.icty.org/x/ file/Legal\%20Library/Rules_procedure_evidence/IT032_ Rev43_en.pdf.

Junge J.F., Kesempatan yang Hilang, Janji yang tak Terpenuhi. Pengadilan HAM Ad Hoc untuk Kejahatan di Tanjung Priok 1984, Jakarta 2008.

Juwana, Hikmahanto, Special Report: Assessing Indonesia's Human Rights Practice in the Post-Soeharto Era: 1998-2003, "Singapore Journal of International \& Comparative Law" 2003, 7.

Kim, Hunjoon, Sikkink K., Explaining the Deterrence Effect 
of Human Rights Prosecutions for Transitional Countries, "International Studies Quarterly" 2010, 54, No. 4.

Kimura, Ehito. The Struggle for Justice and Reconciliation in Post-Suharto Indonesia, "Southeast Asian Studies" 2015, 4, No. 1.

Kontra S., Mereka Bilang Di Sini Tidak Ada Tuhan. Jakarta 2004.

Kontra S., Menerobos Jalan Buntu: Kajian Terhadap Peradilan Militer di Indonesia, Jakarta 2009.

Kovras, Iosif, Truth, Recovery and Transitional Justice: Deferring Human Rights Issues, London 2014.

Kritz, Neil J., Transitional Justice: How Emerging Democracies Reckon with Former Regimes, Vol. II, Washington DC 1995.

Komnas HAM, Laporan Tindak Lanjut Hasil Penyelidikan dan Pemeriksaan Pelanggaran Hak Asasi Manusia di Tanjung Priok. Jakarta 2000.

Komnas HAM, Ringkasan Eksekutif Dari Laporan Hasil Penyelidikan dan Pemeriksaan Pelanggaran Hak Asasi Manusia di Tanjung Priok Tanggal 12 September 1984, Jakarta 2000.

Linton, Suzannah, Accounting for Atrocities in Indonesia, "Singapore Year Book of International Law" 2006, 11.

Marzuki, Suparman, The Human Rights Court in Indonesia; Impunity Perpetuates, Jakarta 2012.

De Greiff P., Mayer-Rieckh A., eds. Justice as Prevention: Vetting Public Employees in Transitional Societies. New York 2007.

Meernik J., Justice and peace? How the International Criminal Tribunal Affects Societal Peace in Bosnia, "Journal of Peace Research” 2005, 42, No. 3 (2005): 271-289. 
Méndez J.E., Accountability for Past Abuses, "Human Rights Quarterly" 1997, 19, No. 2 (1997): 255-282.

Mendez J.E., In Defense of Transitional Justice, [in:] Transitional Justice and the Rule of Law in New Democracies, ed. J. McAdams, Notre Dame 1997.

Mietzner M., The Ambivalence of Weak Legitimacy: Habibie's Interregnum Revisited, "Review of Indonesian and Malaysian Affairs" 2008, 42, No. 2.

Mietzner M., Military Politics, Islam, and the State in Indonesia: From Turbulent Transition to Democratic Consolidation, Leiden 2009.

Mietzner M., Money, Power and Ideology: Political Parties in Post-Authoritarian Indonesia, Honolulu 2013.

Mietzner M., Praetorian Rule and Redemocratisation in South-East Asia and the Pacific Islands: The Case of Indonesia", "Australian Journal of International Affairs" 2013, 67, No. 3.

Mietzner M., Veto Player No More? The Declining Political Influence of the Military in Post-Authoritarian Indonesia, [in:] Democracy and Islam in Indonesia, eds. M. Kunkler, A. Stepan, Columbia 2013.

Mizuno, Kumiko, Indonesian Politics and the Issue of Justice in East Timor, [in:] Governance in Indonesia: Challenges Facing Megawati Presidency, eds. H. Soesastro, A.L. Smith, M.L. Han, Singapore 2003.

O'donnell G., Schmitter P.C., Transitions from Authoritarian Rule: Tentative Conclusions about Uncertain Democracies, London 1986.

Olsen T.D., Reiter A.G., Transitional Justice in Balance: Comparing Process, Weighing Efficacy, Washington DC 2010. 
Olsen T.D., Payne L.A., Reiter A.G., Wiebelhaus-Brahm E., When Truth Commissions Improve Human Rights, "International Journal of Transitional Justice" 2010, 4, No. 3. Paige A., How "Transitions" Reshaped Human Rights: A Conceptual History of Transitional Justice, "Human Rights Quarterly" 2009, 31, No. 2.

Parliamentary Secretariat. Summary of Processes of Legislation on Law on Human Rights Court. 2000.

Parliamentary Secretariat. Minutes Meeting of the TRC Bill. 2004.

Payne L.A., Sikkink K., Transitional Justice in the AsiaPacific: Comparative and Theoretical Perspectives, [in:] Transitional Justice in the Asia-Pasific, eds. R. Jeffery, H.J. Kim, Cambridge 2014.

Risse T., Sikkink K., The Socialization of Internasional Human Rights Norms into Domestic Practices: Introduction, [in:] eThe Power of Human Rights: International Norms $\&$ Domestic Change, ds. Thimas Risse et.al., New York 1999.

Risse-Kappen T., Ropp S.C., Sikkink K. (eds.), The Power of Human Rights: International Norms and Domestic Change, New York 1999.

Robinson G., Indonesia: On a New Course?, [in:] eCoercion and Governance: The Declining Political Role of the Military in Asia, d. M. Alagappa, Stanford 2001: 226-256.

Robinson G., The Fruitless Search for a Smoking Gun, [in:] Roots of Violence in Indonesia, eds. F. Colombijn, T. Lindblad, Singapore 2002: 243-276.

Robinson G., East Timor 1999 Crimes against Humanity: A Report Commissioned by the United Nations Office of the High Commissioner for Human Rights, Commission for Reception, Truth and Reconciliation, 2003. 
Robinson G., If You Leave Us Here, We Will Die: How Genocide Was Stopped in East Timor. New Jersey: Princeton University Press, 2009.

Robison R., Hadiz V,R., Reorganising Power in Indonesia:

The Politics of Oligarchy in an Age of Markets, "Bulletin of Indonesian Economic Studies” 2005, 41 (1).

Santoso B., Evaluasi Kritis Atas Kelemahan UU Peradilan $H A M$, Paper presented at the Workshop Merumuskan Amandemen Undang-Undang Peradilan HAM, Yogyakarta, 2003.

Sikkink, Kathryn, The Justice Cascade: How Human Rights Prosecutions Are Changing World Politics (The Norton Series in World Politics), WW Norton \& Company, 2011. Sikkink, Kathryn, Carrie Booth Walling, "The Impact of Human Rights Trials in Latin America", "Journal of Peace Research" 2007, 44, No. 4.

Slater D., Indonesia's Accountability Trap: Party Cartels and Presidential Power after Democratic Transition, "Indonesia" 2004, 78.

Slater D., The Ironies of Instability in Indonesia, "Social Analysis" 2006, 50, No. 1.

Snyder J., Vinjamuri L., Trials and Errors: Principle and Pragmatism in Strategies of International Justice, "International Security" 2004, 28, No. 3.

Stover E., Weinstein H.M. (eds.), My Neighbour, My Enemy:

Justice and Community in the Aftermath of Mass Atrocity, Cambridge 2004.

Stromseth J., Wippman D., Brooks R., Can Might Make Rights? Building the Rule of Law After Military Interventions. Cambridge: Cambridge University Press, 2006. Suh J., The Politics of Transitional Justice in Post-Suharto Indonesia, Ohio 2012. 
Suh J., Legacies of International Human Rights Pressure Against New Order Indonesia, "The Korean Journal of International Relations (Gukjejeongchinonchong)" 2013, 53 No. 4, (2013): 401-432.

Sulistiyanto, Priyambudi, Politics of Justice and Reconciliation in Post-Suharto Indonesia, "Journal of Contemporary Asia" 2007, 37, No. 1.

Sundari E.K., Parlemen dan HAM: Visi Tanpa Eksekusi, [in:] Hak Asasi Manusia dalam Pusaran Politik Transaksional: Penilaian terhadap Kebijakan HAM dalam Produk Legislasi dan Pengawasan DPR RI Periode 2004-2009, ed. I. Saptaningrum, Jakarta 2011.

Suparman, Djadja, Jejak Kudeta (1997-2005): Catatan Harian Jenderal TNI (Purn) Djadja Suparman, Jakarta 2013. Suryadinata L., Nationalism \& Globalization: East \& West, Singapore 2000.

Setara Institute, Indeks Kinerja Penegakan HAM 2011, Jakarta 2011.

Setara Institute, Indeks Kinerja Penegakan HAM 2012, Jakarta 2012.

Summary of Constitutional Court Decision No. 006/PUUIV/2006 on the Law No. 27/2004 on the Truth and Reconciliation Commission. 2006.

TAP MPR No. V 2000 tentang Pemantapan Persatuan dan Kesatuan Nasional (Decision of the People's Consultative Assembly No. V 2000 on Consolidation of National Unity). TAP MPR No. XVII of 1998 Tentang Hak Asasi Manusia (Decision of the People's Consultative Assembly No. XVII of 1998 on Human Rights).

Tanter R., Ball, Desmond, Van Klinken G. (eds.), Masters of Terror: Indonesia's Military and Violence in East Timor, New York 2006. 
Teitel R.G., How are the New Democracies of the Southern Cone Dealing with the Legacy of Past Human Rights Abuses, [in:] Transitional Justice: How Emerging Democracies Reckon with Former Regimes, ed. N.J. Kritz, Washington DC 1995.

Teitel R.G., Transitional Justice, New York 2000.

Teitel R.G., Transitional Justice Genealogy, "Harvard Human Rights Journal" 2003, 16, No. 1.

Undang-Undang No. 311997 tentang Peradilan Militer (Law on Military Tribunal).

Undang-Undang No. 391999 tentang HAM (Law on Human Rights).

\section{Websites and Newspapers}

Hukumonline.com. "Kasus Tanjungpriok: Saksi Ikhlas Walaupun Disiksa dan Ditembak", 2003. Retrieved 16 June, 2016, from http://www.hukumonline.com/berita/baca/ hol9208/kasus-tanjungpriok-saksi-ikhlas-walaupundisiksa-dan-ditembak.

Liputan6.com. "Korban Kasus Tanjung Priok Mencabut Islah" 2001. Retrieved 5 June, 2016, from http://news. liputan6.com/read/20404/korban-kasus-tanjungpriokmencabut-islah.

Liputan6.com. "Wiranto: Tuduhan PBB Pembunuhan Karakter" 2003. Retrieved 8 February, 2015, from http://news. liputan6.com/read/50225/wiranto-tuduhan-pbb-pembunuhan-karakter.

Merdeka.com. "Referendum penentu berpisahnya provinsi ke-27 Indonesia”. 2012. Retrieved 30 June, 2016, from https://www.merdeka.com/dunia/rereferendum-penentu-berpisahnya-provinsi-ke-27-indonesia.html.

Kompas. (1999), Korban Peristiwa Tanjung Priok Mengadu 
ke Puspom Retrieved 20 April, 2017, from http://www. kontras.org/home/index.php?module=berita\&id $=245$. Kompas. (2000), Pembela Kasus Priok Desak Panggil Soeharto, Retrieved 20 April, 2017, from http://www.kontras.org/home/index.php? module=berita\&id $=430$. Tempo Majalah, "Jaksa Agung Titipan Tentara?", 30 July-5 August 2001, No. 22/XXX.

Tempo.co. (2003), KontraS Mengadukan Intimidasi ke Pengadilan Retrieved 6 June, 2016, from http://nasional. tempo.co/read/news/2003/10/29/05525915/kontrasmengadukan-intimidasi-ke-pengadilan.

Tabloid DeTAK. Interview with Yusron Zaenuri. (2000).

\begin{abstract}
The fall of 32-year old of authoritarian regime in Indonesia led by General Suharto, marked the beginning of a transition from an authoritarian regime to democracy, and made it possible for transitional justice agenda to be adopted by the state. In general, the adoption of these transitional justice measures was positive in terms of the promotion of state accountability and human rights protection. However, the implementation was deeply unsatisfactory and totally failed in fulfilling the objectives for truth and justice. Explaining such poor outcomes of transitional justice and human rights as resulting from the lack of the state's political willingness is unsatisfactory because it assumes the state is monolithic, ignoring the fact that during the transition and in the period of what most scholars referred to as consolidation, state institutions and agents are willing to adopt transitional justice measures with different motivations and interests. My paper departs from this doubt. It seeks to explain further and understand transitional justice as unfinished agenda in Indonesia's democracy by linking it with the nature of democratic transition that has taken place in the country since 1998.
\end{abstract}

Keywords: transitional justice; democratic transition; human rights; democratization; Indonesia 


\section{Imelda Masni Juniaty Sianipar}

Center for Social Justice and Global Responsibility (CSJGR);

Department of International Relations, Universitas Kristen Indonesia

\section{Arthuur Jeverson Maya}

Center for Social Justice and Global Responsibility (CSJGR);

Department of International Relations, Universitas Kristen

Indonesia

ORCID ID: https://orcid.org/ 0000-0002-1414-2873

\section{Populism in The Philippines and Human Rights}

\section{Introduction}

Populism and human rights are a contradiction. Many scholars argue that once populist leaders come to power, human rights are under threat ${ }^{1}$. In the World Report 2017, Hu-

1 P. Alston, The Populist Challenge To Human Rights, "Journal of Human Rights Practice" 2017, No. 9, p.1; G. Neuman, Populist Threats to the International Human Rights System, https://www.cambridge.org/ core/services/aop-cambridge-core/content/view/DFB3520DD9D455FC66DCF1986243AE7B/9781108485494c1_1-19.pdf/populist_threats_ to_the_international_human_rights_system.pdf,p.1 [access: 12.11 .2020 ]; V. Bilkova, Populism and Human Rights, [in:] Netherlands Yearbook of International Law 2018 - Populism and International Law, eds. J.E. Nijman, W.G. Werner, The Hague 2019, p. 143; J.P. Braun, Populism and Human Rights in Theory and Practice: Chavez's Venezuela and Fujimori's Peru. Thesis, https://digitalcommons.unl.edu/poliscitheses/9, 2011, p. 2 [access: 12.11.2020]; K. Roth, The Dangerous Rise of Populism: Global Attacks on Human Rights Values, "Journal of International Affairs", The Next World Order: Special 70 th Anniversary Issue 2017, p. 79; R.A. Pernia, Human Rights in a Time of Populism: Philippines under Rodrigo 
man Rights Watch documented many populist leaders endangering human rights and encouraging abuse ${ }^{2}$. China's Xi Jinping, for example, has pursued the toughest crackdown on critical voices in two decades. Prime Minister Narendra Modi of India tried to shut down critical civic groups as he closed his eyes to intimidation and hate crimes by Hindu nationalist groups against religious and ethnic minorities. President Recep Tayyip Erdoğan of Turkey took advantage of a coup at - tempt to crush opposition voices. President Rodrigo Duterte of the Philippines has openly called for summary executions of suspected drug dealers and users and even of human rights activists who defend them ${ }^{3}$. This unexpected series of developments adds greater urgency to the study of populism and its effect on human rights ${ }^{4}$. And the Philippines as a case study has attracted much attention.

The international community is highlighting the Philippines because Duterte has led to a serious breach of human rights 5 . OHCHR reports that since the launch of the

Duterte, "Asia-Pacific Social Science Review" 2019, Vol. 19 (3), p. 57; S. Levitsky, J. Loxton, Populism and competitive authoritarianism in the Andes, "Democratization" 2013, Vol. 20, No. 1, pp. 107-108; D.G. Timberman, Philippine Politics Under Duterte: A Midterm Assessment, https:// carn-egieendowment.org/2019/01/10/philippine-politics-un-der-duterte-midterm-assessment-pub-78091, p. 1 [access: 12.11.2020].

2 Populist leaders' encourage rights abuses, Human Rights Watch says, https://www.bbc.com/news/world-38593496 [access: 12.11.2020].

3 Human Rights Watch [a], World Report 2017: Demagogues Threaten Human Rights, https://www.hrw.org/news/2017/01/13/world-report2017-demagogues-threaten-human-rights, p. 3 [access: 12.11.2020].

4 G.L., Neuman, p. 1.

5 V. Bilkova, p. 154; R.A. Pernia,p. 61; Human Rights Watch [a], p. 3; S.R. Maxwell, 2018, Perceived threat of crime, authoritarianism, and the rise of a populist president in the Philippines, "International Journal 
Double Barrel Government Campaign, from 1 July 2016 to 31 January 2019, thousands of people - and possibly more than 25,000 - have been killed in police and vigilante operations ${ }^{6}$. Between 1 June 2016 and 21 April 2020, the Human Rights Commission of the country documented the killing of 73 children in the context of the campaign against illegal drugs - 62 males and 11 females - although these figures are not exhaustive. The youngest victim was five months $\mathrm{old}^{7}$. According to OHCHR, there were at least 248 human rights defenders, legal professionals, journalists and trade unionists killed in connection with their work in the Philippines between 2015 and $2019^{8}$. In addition, Duterte shut down mass media such as Rappler, which had been critical of the Duterte administration?.

Duterte's crimes against humanity have reached an alarming level. In a speech address to the High-Level Segment of HRC44 in Geneva, Michelle Bachelet stated that Duterte's national security policies have threatened human rights ${ }^{10}$. The UN Human Rights Office has therefore stressed the need for

of Comparative and Applied Criminal Justice" 2018, p. 1; D.T. Johnson, J. Fernquest, Governing through Killing: The War on Drugs in the Philippines, "Asian Journal of Law and Society" 2018, No. 5, p. 360.

6 United Nations [a], Bachelet renews call for accountability in Philippines war on illegal drugs 2020, https://news.un.org/en/story/2020/06/1067462 [access: 12.11.2020].

7 OHCHR [a], Report of the United Nations High Commissioner for Human Rights on the situation of human rights in the Philippines, A/HRC/ 44/22, 29.06.2020, https://www.ohchr.org/Documents/Countries/PH/ Philippines-HRC44-AEV.pdf, p. 5 [access: 12.11.2020].

8 Ibidem, p. 10.

9 Amnesty International, Assessment of The Human Rights Situation in The Philippines Against Objective Criteria for Action by The Un Human Rights Council, 11.06.2019, https://www.amnesty.org/download/ Documents/IOR4004662019ENGLISH.PDF, p. 8 [access: 12.11.2020].

10 OHCHR [a], op.cit., p. 3. 
independent, impartial and credible investigations into violations and for a system to compile and publish consistent, disaggregated data on all allegations of extrajudicial killings. This article seeks to understand the relationship between populism and human rights in the case of the Philippines. To what extent populist leaders have a chance to exercise human rights, and what factors provide opportunities for these populist leaders. As a result, early prevention can be used when a similar situation occurs.

\section{Defining Populism}

Populism is a divisive idea in many respects ${ }^{11}$. According to Coupal, it is difficult to set a precise definition for this term. While it is hard to define populism, it is easy to explain and characterize: you know it when you see it. Paul Taggart stresses that populism has an intrinsic quality of the chameleon, which means that it often takes on the hue of the world in which it exists. As a consequence, while populism has been used almost exclusively in the past to describe developing countries ruled by charismatic leaders, the term has been gradually extended to Western European policies ${ }^{12}$. According to Bart Bonikowski and Noam Gidron, there are three main approaches in the study of populism: as a political strategy, a political ideology, and as a discursive style ${ }^{13}$.

11 R. Dornbusch, S. Edward, The Macroeconomics of populism in Latin America, Chicago 1991, p. 8; P.D. Kenny, Populism in Southeast Asia, Cambridge 2019, p. 8.

12 Y. Coupal, Macroeconomics of Populism in Venezuela, http://citeseerx.ist.psu.edu/viewdoc/download?doi=10.1.1.547. 6434\&rep=rep1\&type=pdf, p. 5-6 [access: 12.11 .2020 ].

13 B. Bonikowski, N. Gidron, Multiple Traditions in Populism Research, "APSA Comparative Politics Newsletter" 2016, Vol. 26 (12), p. 8. 
As a political strategy, this approach focuses on the attributes of political leaders and stresses the unmediated relationship between leaders and their supporters. Alan Knight defines populism as a political style. While, Kurt Weyland emphasizes populism as a political strategy through which a personalistic leader seeks or exercises government power based on direct, unmediated, uninstitutionalized support from large numbers of mostly unorganized followers ${ }^{14}$. Kenneth Robert similarly refers to populism as the top-down political mobilization of mass constituencies by personalistic leaders who challenge elite groups on behalf of an ill-defined pueblo, or "the people"15. And Paul Kenny who specifically observes the emergence of populism in Southeast Asia defines populism as a charismatic mobilization of a mass movement in pursuit of political power ${ }^{16}$.

As a political ideology, populism emphasizes the content of ideology. An influential definition of populism as an ideology was suggested by Cas Mudde. According to Mudde, populism is not merely as a political style. It should be understood as an ideological feature. Accordingly, populism is understood as a thin-centered ideology that considers society to be ultimately separated into two homogeneous and antagonistic groups, "the pure people" versus "the corrupt elite," and which argues that politics should be an expression of the volonté générale (general will) of the people ${ }^{17}$.

14 K. Weyland, Clarifying a Contested Concept: Populism in the Study of Latin American Politics, "Comparative Politics" 2001, Vol. 34, No. 1, p. 14.

15 K.M. Roberts, Latin America's Populist Revival, "SAIS Review of International Affairs" 2007, Vol. 27 (1), p. 5.

16 P.D. Kenny, op.cit,, p. 1.

17 C. Mudde, Populist Radical Right Parties in Europe, Cambridge 2007, p. 23. 
According to Bart and Gidron, ideology here means an interconnected set of ideas that derive meaning from their relationship to one another. In the case of populism, these ideas revolve around the Manichean contrast between the corrupt elite and the morally pure people. By characterizing this ideology as "thin-centered," scholars stress that populism is not a complete worldview that offers consistent answers to a wide range of important political questions; instead, populism attaches itself to other full-fledged ideologies such as socialism or nationalism ${ }^{18}$.

As a discursive style, populism is predicated on the fundamental conflict between the corrupt elite and the people. Populism as a discourse is best thought of as a rhetorical style of different ideological persuasions used by political actors. This approach views populism as an attribute of the message and not the speaker. This makes it possible under different conditions for political leaders to use different degrees of populism. Some political actors may, of course, be more populist than others, but this can only be established by examining the variation in discursive styles within the actors. This perspective opens the possibility of examining the contextual determinants and variations of populist rhetoric through historical periods and geographical regions ${ }^{19}$. The work of Laclau has been particularly influential in shaping the discursive approach. Laclau recognizes that populism involves the division of the social scene into two camps. This division presupposes the presence of some privileged signifiers which condense in themselves the signification of a whole antagonistic camp (the 'regime', the 'oligarchy', the

18 B. Bonikowski, N. Gidron, op.cit, p. 8.

19 Ibidem. 
'dominant groups', and so on, for the enemy; the 'people', the 'nation', the 'silent majority', and so on, for the oppressed underdog - these signifiers acquire this articulating role according to a contextual history $)^{20}$. For Laclau, the symbolic distinction that constitutes populist discourse between 'us' and 'them' is an instance of relational 'empty signifiers' that, depending on the social context, can take on varied content. Via a process of "identification" (i.e. classification), these categories obtain their significance, whereby particular social classes are perceived as "the people" (us) and opposed to hierarchical "others" (them) ${ }^{21}$.

\section{Defining Human Rights}

According to English philosopher John Locke, people have natural rights to life, liberty and property. No one ought to harm another in his life, health, liberty, or possessions: for men being all the workmanship of one omnipotent ${ }^{22}$. United Nations defines human rights as rights inherent to all human beings, regardless of race, sex, nationality, ethnicity, language, religion, or any other status. Human rights include the right to life and liberty, freedom from torture and slavery, freedom of speech and thought, the right to work and education, and much more. Everybody is entitled, without prejudice, to these rights ${ }^{23}$.

20 E. Laclau, On Populist Reason, London 2005, p. 84-87.

21 Ibidem, p. 10.

22 J. Locke, C.B. Macpherson, Second Treatise of Government, Indianapolis 1980, p. 8-9.

23 United Nations [b], Global Issues: Human Rights, https://www. un.org/en/global-issues/human-rights [access: 1.08.2021]. 
The United Nations has defined a number of internationally recognized rights, including civil, cultural, economic, political, and social rights. In 1976, the International Covenant on Economic, Social, and Cultural Rights, as well as the International Covenant on Civil and Political Rights and the First Optional Protocol came into effect. The Optional Second Protocol was then adopted in 1989.

The International Covenant on Economic, Social and Cultural Rights aims to promote and secure include: the right to work in equal and favorable conditions; the right to social security, to an acceptable standard of life and to the highest level of physical and mental well-being that can be attained; the right to education and to benefiting from cultural freedom and scientific progress. The International Covenant on Civil and Political Rights deals with such rights as freedom of movement; equality before the law; the right to a fair trial and presumption of innocence; freedom of thought, conscience and religion; freedom of opinion and expression; peaceful assembly; freedom of association; participation in public affairs and elections; and protection of minority rights. It prohibits arbitrary deprivation of life; torture, cruel or degrading treatment or punishment; slavery and forced labour; arbitrary arrest or detention; arbitrary interference with privacy; war propaganda; discrimination; and advocacy of racial or religious hatred ${ }^{24}$.

\section{Relationship Between Populism and Human Rights}

Populism and human rights are like double-edged swords. Populism itself contains elements that are supportive of hu

24 Ibidem. 
- man rights and those that are less, or not at all, so. Because of the simultaneous presence of these two categories of elements, populists have an uneasy and somewhat ambivalent relationship to human rights ${ }^{25}$. On the one hand, populist leaders emerge to voice to those who feel marginalized by the political status quo. On the other hand, they ignore the populist challengers.

The experience of a number of countries shows that the emergence of populism will have a negative impact on human rights. In Latin American such as Peru under Alberto Fujimori, Venezuela under Hugo Chavez, and, to a lesser degree, Bolivia under Evo Morales and Ecuador under Lucio Gutierrez and Rafael Correa, fragile democracies slid into competitive authoritarianism, or electoral regimes in which widespread incumbent abuse skewed the playing field against opponents ${ }^{26}$. Trump and various politicians in Europe seek power through appeals to racism, xenophobia, misogyny, and nativism. They all claim that the public accepts violations of human rights as supposedly necessary to secure jobs, avoid cultural change, or prevent terrorist attacks. In fact, disregard for human rights offers the likeliest route to tyranny ${ }^{27}$. In Russia, Vladimir Putin responded to popular discontent in 2011 with a repressive agenda, including draconian restrictions on free speech and assembly, unprecedented sanctions for online dissent, and laws severely restricting independent groups.

China's leader, Xi Jinping, concerned about the slow - down in economic growth, has embarked on the most

25 V. Bilkova, p. 153.

26 S. Levitsky, J. Loxton, p. 107.

27 Human Rights Watch (a), 2017. 
intense crackdown on dissent since the Tiananmen era ${ }^{28} \cdot{ }^{28}$ Hong Kong's human rights record took a dark turn. Hong Kong courts disqualified four pro-democracy lawmakers in July and jailed three prominent pro-democracy student leaders - Alex Chow, Nathan Law and Joshua Wong - in August 2017 for their roles in a protest at the Civic Square in front of the Central Government Complex in Tamar, Admiralty, on 26 and 27 September 2014. Wong, Law and Chow were handed sentences of six to eight months by the Court of Appeal for their role in 2014's massive Umbrella Movement protests, which called for fully free leadership elections and were an unprecedented challenge to Beijing ${ }^{29}$. Prime Minister Narendra Modi of India tried to shut down critical civic groups as he closed his eyes to intimidation and hate crimes by Hindu nationalist groups against religious and ethnic minorities ${ }^{30} .{ }^{30}$ A striking finding of the Hate Crime watch shows that as many as $90 \%$ of religious hate crimes (especially to Muslims) have occurred after Modi led the BJP to power at the Centre in $2014^{31}$.

According to Bilkova, there are three main arguments that populists use to criticize the concept of human rights. The arguments can be invoked separately but they can also be combined. The first is the security argument. It builds on

28 Ibidem.

29 The Jakarta Post, Crowds rally in Hong Kong after activists jailed, 20.08.2017, https://www.thejakartapost. com/news/2017/08/20/crowdsrally-in-hong-kong-after-activists-jailed.html [access: 12.11.2020].

30 Human Rights Watch (b), World Report 2019, https://www.hrw. org/sites/default/files/world_report_download/hrw_world_report_2019. pdf, p. 23 [access: 12.11.2020].

31 R. Ayyub, What a Rising Tide of Violence Against Muslims in India Says About Modi's Second Term, 2019, https://time.com/5617161/ india-religious-hate-crimes-modi/ [access: 12.11.2020]. 
security concerns, especially those related to terrorism and, more recently, to migration. It alleges that human rights as currently understood prevent states from countering modern security threats and from ensuring the adequate protection of the people. The second is the legitimacy argument. It contends that the human rights project has stopped serving its original purpose, that of guaranteeing the well-being of the people. It has been hijacked to serve particular groups and promote particular agendas. The third is the democracy argument. It states that the concept of human rights is at odds with the principle of democracy, because it favours the interests of minorities over those of the majority ${ }^{32}$.

In addition, in his research on Peru under Fujimori and Venezuela under Chavez, Joseph Braun shows that populism appears to be adversarial to basic civil and political human rights by its very nature. This enmity is amplified when the populist regime exhausts the resources for generous social programs. Furthermore, the combination of a populist regime with a real security threat is found to be a particularly dire situation for human rights. Fujimori committed drastic human rights violations due to the economic crisis. As the money for his social programs dried-up, Fujimori's support among the lower classes dwindled. His regime finally had to resort to election-rigging to essentially falsify a populist mandate ${ }^{33}$. The situation was exacerbated by intensifying public protests demanding Fujimori's removal as President. In Venezuela, meanwhile, Braun felt that populism was less harmful to human rights because he benefited from the oil boom when Chavez came to power in 1998. Chavez is

32 V. Bilkova, p. 155.

33 J.P. Braun, p. 38. 
able to fulfill his social program with the petrodollars of his country. This has helped Chavez to retain widespread support without having to remove domestic opposition entirely $^{34}$. In addition, Chaves has a charisma that hypnotizes Venezuela and thus provides Chavez's policies with disproportionate support ${ }^{35}$.

\section{The rise of Duterte}

Weyland describes populism as a political strategy through which a personalistic leader seeks or exercises government power based on direct, unmediated uninstitutionalized support from large numbers of mostly unorganized followers. Mudde emphasizes a thin-centered ideology that essentially considers that society is divided into two homogeneous and antagonistic groups, "the pure people" versus "the corrupt elite," and insists that politics should be an expression of the people's general will. And Laclau stresses the essential nature of populism, namely an "empty signifier," which provides a means by which anyone can identify with the people as a whole.

Rodrigo Duterte, 71 years old, was elected as the $16^{\text {th }}$ President of the Philippines on May 10, 2016, succeeding Benigno Aquino III. According to Teehankee and Thompson, Duterte's phenomenon is not a revolt of the poor. It is middle-class driven. It is an angry protest most acute among the modestly successful, including call center workers, Uber drivers, and overseas Filipino workers. In project-

34 Ibidem.

35 I.M.J. Sianipar, Kebangkitan Populisme di Amerika Latin, "The Rise of Populism in Latin America”, Thesis, Yogyakarta 2012, p. 65. 
ing his populist persona, Duterte identified the "them" he was against as drug traffickers, corrupt or inept officials, oligarchs, his rival and critics in the Dilawan camp (that is, party supporters of Roxas and Aquino) and in the media, and even the Catholic Church. Surprisingly, his strategy appealed to a large number of voters who were already frustrated with or angered by the elite. Drawn to Duterte's charisma, the frustrated voters, who are mostly from the middle and upper classes, constituted Duterte's "we, the people" in his campaign against "them" ${ }^{36}$.

The electoral polling data from the 2016 election suggest that Duterte won votes across socio-economic classes. Younger, wealthier and more educated sections of the population were Duterte's strongest base of support. Teehankee and Thompson believe the phenomenon of Duterte is not the revolt of the poor. It's driven by the middle class. It is an angry protest most acute among the modestly successful, including call center workers, Uber drivers, and overseas Filipino workers.' Furthermore, Coronel notes that the 'new middle classes' are his 'hardcore supporters', including Filipino nannies, nurses, seamen and construction workers working overseas, and the digital underclass working in the booming call centers in Manila and other cities ${ }^{37}$.

Although Duterte might appear to be unsophisticated and crude, he is politically savvy and attuned to the attitudes and concerns of average Filipinos. As a successful, nononsense mayor of Davao who prioritized law and order

36 J.J. Capuno, Dutertenomics: Populism, Progress, and Prospects, "Asian Economic Policy Review" 2020, p. 4.

37 C.G. Ramos, Change without Transformation: Social Policy Reforms in the Philippines under Duterte, "Development and Change" 2020, Vol. 51 (2), p. 490. 
over legal protections for suspected criminals, he ran on his reputation. Duterte's campaign's central theme was that his effective leadership will produce dramatic change. He heaped criticism on the Manila-based elite during his campaign, vowed to carry out a national war on illegal drugs and violence. During his campaign, he heaped criticism on the Manila-based elite, vowed to undertake a nationwide assault on illegal drugs and criminality, and promised to change the government to a federal system. His victory over Mar Roxas, who placed a distant second, signaled that the promise of change was more compelling than continuity ${ }^{38}$.

Within six months of his taking office, Duterte vowed to eliminate the drug issue and he followed through with a quick and ruthless campaign to order executions for those accused of drug involvement and who do not surrender peacefully. His narrative to justify the drug war was based on allegations that the Philippines is infested with illicit drugs and that so many communities are rampant with addiction, causing violence, disruption and a diminished quality of life. In the Philippines, he claimed that there were around three to four million drug criminals.

Duterte promised to eradicate the drug problem within six months of his taking office and he followed through with a swift and brutal campaign of ordering executions for those suspected of drug involvement and who do not peaceably surrender. His narrative to justify the drug war was based upon claims that the Philippines is infested with illegal narcotics and that addiction is running rampant in too many neighborhoods causing crime, disruption and a lowered quality of life. He estimated about three to four million

38 D.G. Timberman, p. 3. 
drug criminals in the Philippines. This estimation is over two million higher than the 2012 report by the Dangerous Drug Board (DDB) of the Philippines. Although no Philippine organization, public or private, can reach Duterte's estimated number or provide proof of the veracity of his statements, his message appears to resonate with many Filipinos and seems to fuel his continued popularity ${ }^{39}$. More than 16 million Filipinos (about 39 percent of eligible voters) who voted for him to take office on 9 May 2016 were obviously attracted by his platform (see Table 1). The size of his winning plurality and margin of victory compare favourably with the last five presidential elections (see Figure 1).

Figure 1. Duterte win compared to the other post-Edsa precidencies

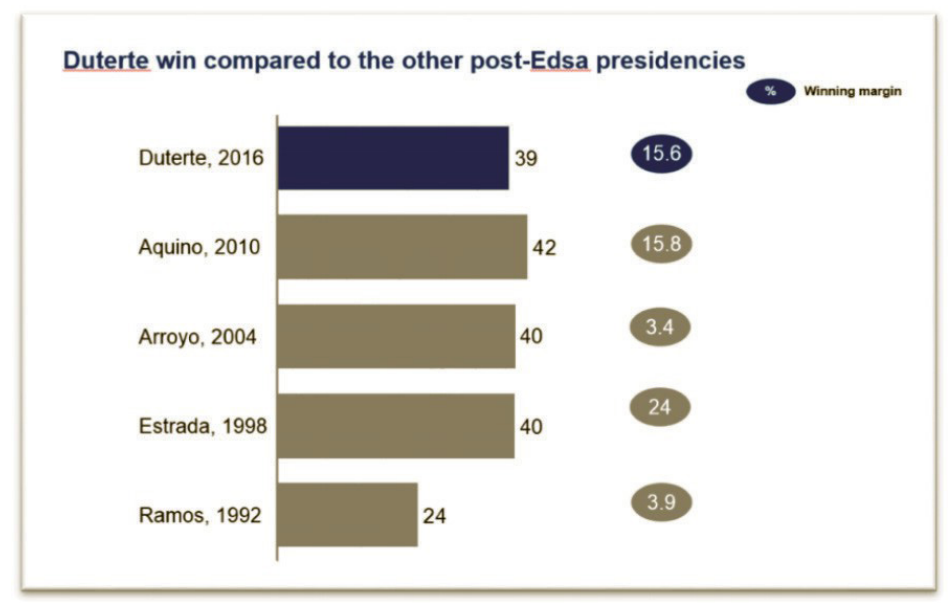

Source: M. Cook, L. Salazar, p. 3.

39 S.R. MaxwelL, Perceived threat of crime, authoritarianism, and the rise of a populist president in the Philippines, "International Journal of Comparative and Applied Criminal Justice" 2018, p. 2. 
Table 1. Presidential polls and election result (in \%)

\begin{tabular}{|l|c|c|c|c|}
\hline & Duterte & Roxas & Poe & Binay \\
\hline Sept 2015 SWS & 11 & 20 & 26 & 24 \\
\hline Sept 2015 PA & 16 & 20 & 26 & 19 \\
\hline Dec 2015 PA & 23 & 17 & 21 & 33 \\
\hline Jan 2016 SWS & 18 & 21 & 24 & 31 \\
\hline Jan 2016 PA & 20 & 20 & 30 & 23 \\
\hline March 2016 SWS & 21 & 22 & 27 & 24 \\
\hline April 2016 PA & 35 & 17 & 23 & 16 \\
\hline May 2016 SWS & 33 & 20 & 22 & 13 \\
\hline 9 May election* & 39 & 23 & 21 & 13 \\
\hline
\end{tabular}

Source: M. Cook, L. Salazar, The Differences Duterte Relied Upon to Win, "Iseas - Yusof Ishak Institute" 2016, No. 34, p. 2 [access: 12.11.2020].

\section{Human Rights Violation under Duterte}

The Philippines has a longstanding history of abuses of human rights. The national martial law imposed under President Ferdinand Marcos (1965-1986) from September 1972 to January 1981 resulted in a surge of severe violations committed by the military ${ }^{40}$. During the Ferdinand Marcos dicatorship, over 3,000 such killings were reported ${ }^{41}$. Under the administration of President Gloria Macapagal Arroyo (2001-2010), human rights abuses continued throughout the country, with hundreds of leftist activists killed by the military in targeted counterinsurgency operations against the New People's Army (NPA). While the number of serious

40 D. Louys, The Observatory. I'll Kill You Along with Drug Addicts: President Duterte's war on human rights defenders in the Philippines, https://www.omct.org/en/resources/reports/ill-kill-you-along-with-drugaddicts-president-dutertes-war-on-human-rights-defenders-in-the-philippines, p. 5 [access: 12.11.2020].

41 D. Tolbert, Duterte's 'War on Drugs' Brings Dictatorship Methods Back to the Philippines, https://www.ictj.org/news/duterte-philip pines-drug-dictatorship [access: 12.11.2020]. 
violations of human rights declined during President Benigno Simeon C. Aquino III's administration (2010-2016), the killings of prominent human rights defenders continued ${ }^{42}$.

Since President Duterte took office on June 30, 2016, the civil society has been operating in an increasingly hostile environment. President Duterte has publicly expressed his blatant disregard for human rights on several occasions in relation to his 'war on drugs' and has repeatedly threatened to kill human rights activists. On August 5, 2016, Duterte said, "I don't care about human rights, believe me." On November 28, 2016, Duterte threatened to kill human rights activists critical of his 'war on drugs.' On December 7, 2016, Duterte continued his invectives and threatened lawyers defending drug suspects. On May 19, 2017, Duterte menaced to human rights activists, "I'll kill you along with drug addicts, I'll decapitate you." The Duterte administration has intentionally demonised human rights defenders to the public. This has led to a distortion of the public image of human rights and its advocates ${ }^{43}$.

The "war on drugs" by Duterte has already claimed over 7,000 lives as of April 2017 and shows no sign of slowing down. Human Rights Watch and international news outlets reported the same number, while Amnesty International estimates that around 9,000 were killed by both police and vigilantes ${ }^{44}$. Johnson and Fernquest noted that in the first year of Duterte's war on drugs, the frequency of extra-judicial killing in Duterte's war on drugs is far higher than

42 D. Louys, p. 5.

43 Ibidem, p. 9.

44 D. Simangan, Is the Philippine "War on Drugs" an Act of Genocide?, "Journal of Genocide Research" 2017, p. 1. 
the frequency of extrajudicial killing under the martial law imposed by Marcos in the 1970s (see Table 2$)^{45}$.

Table 2. Drug-related killings reported in the first year of the Philippine war on drugs

\begin{tabular}{lcccc}
\hline Source & \multicolumn{1}{c}{ Time period } & Killings & By police & By other \\
\hline Police & $7 / 1 / 2016$ to $1 / 31 / 2017$ & 7,080 & - & - \\
Police & $7 / 1 / 2016$ to $6 / 30 / 2017$ & 4,998 & - & - \\
Rappler & $7 / 1 / 2016$ to $4 / 2 / 2017$ & 7,080 & - & - \\
AI & $7 / 1 / 2016$ to $1 / 21 / 2017$ & 7,025 & - & - \\
HRW & $7 / 1 / 2016$ to $1 / 31 / 2017$ & 7,080 & - & - \\
ABS-CBN & $7 / 1 / 2016$ to $3 / 31 / 2017$ & 9,432 & 2,692 & - \\
New York Times & $7 / 1 / 2016$ to $4 / 25 / 2017$ & 9,400 & - & - \\
Bloomberg & $7 / 1 / 2016$ to $6 / 30 / 2017$ & 5,000 & 3,151 & 1,847 \\
ABC News & $7 / 1 / 2016$ to $6 / 30 / 2017$ & 5,200 & 3,000 & 2,000 \\
\hline
\end{tabular}

Source: D.T. Johnson, J. Fernquest, 2018, p. 364 [access:12.11.2020].

According to the World Report 2019 of Human Rights Watch, Duterte administration's “war on drugs" expanded into areas outside the capital, Metro Manila, including to the provinces of Bulacan, Laguna, Cavite, and the cities of Cebu and General Santos. The Philippine Drug Enforcement Agency (PDEA) stated that 4,948 suspected drug users and dealers died during police operations from July 1, 2016 to September 30, 2018. However, this does not include the thousands of others killed by unidentified gunmen. Duterte has vowed to continue his anti-drug campaign until his term ends in 2022. Duterte has also vowed to protect police officers and agents carrying out the "drug war" from prosecution $^{46}$.

In January 2018, Duterte attacked media freedom by threatening the closure of Rappler.com, an online news outlet critical of the "war on drugs." In November, the Depart-

45 D.T. Johnson, J. Fernquest, p. 364.

46 Human Rights Watch (b). 
ment of Justice indicted Rappler and its editor and founder, Maria Ressa, for tax evasion. This was followed by months of attacks and harassment by the Duterte Government and its supporters against Rappler. The killings of journalists continued in 2018, with six unidentified gunmen killed in different parts of the country.

In March 2019, current High Commissioner Michelle Bachelet, in her first annual update to the 40th session of the Human Rights Council, expressed deep concern over the scale of killings noting that several sources now estimate that up to 27,000 people may have been killed. She also flagged, inter alia, the lack of investigations and accountability at national level, and noted that Special Rapporteurs of this Council have been subjected to threats; and opposition politicians, human rights defenders and journalists have been threatened, attacked and jailed ${ }^{47}$.

In June 2020, in her address to Member States of United Nations in Geneva on the opening day of the Council's $44^{\text {th }}$ session, Michelle Bachelet reiterated concerns over human rights violations in the Philippines. The findings of the OHCHR report are very serious. More than 248 human rights defenders, lawyers, journalists and trade unionists were killed between 2015 and 2019. This includes a large number of environmental and indigenous peoples' rights defenders. Human rights defenders are routinely smeared as terrorists, enemies of the State and even viruses akin to COVID $-19^{48}$.

47 Amnesty International, op.cit., p. 2.

48 OHCHR (b), $44^{\text {th }}$ session of the Human Rights Council Enhanced interactive dialogue on the situation of human rights in the Philippines, https://www.ohchr.org/EN/NewsEvents/Pages/DisplayNews.aspx?NewsID $=26016 \&$ LangID $=E$ [access: 12.11 .2020$]$. 
OHCHR also documented that the campaign against illegal drugs has been linked to the deaths of 73 children. The youngest victim was five months old ${ }^{49}$. The operation was being carried out "without due regard for the rule of law, due process and the human rights of people who may be using or selling drugs. The killings have been widespread and systematic - and they are ongoing." The High Commis sioner also highlighted "near-impunity" for perpetrators of illegal killings during police operations. the report details how the Philippines Police Internal Affairs Service (IAS) automatically investigates any deaths that occur during police operations, and yet of more than 4,580 investigations, "the Government has cited only one case - that of 17-year-old Kian delos Santos - where three police officers were convicted of a drug campaign-related killing" ${ }^{50}$.

\section{How Duterte legitimizes his human rights abuses?}

According to Bilkova, populist leaders use three arguments to criticize human rights, namely the security argument, the legitimacy argument and the democracy argument. In the case of the Philippines, a discourse that succeeded in influencing Filipinos facilitated Duterte's human rights violations, namely the issue of narcotics is a national threat. Maxwell's research shows that $86.6 \%$ Filipinos view drug problem is a national threat and serious crisis ${ }^{51}$. (see figure 2). According to the 2017 Pew Research Center survey, Duterte and his policies are widely popular nationally, despite international concerns

\footnotetext{
49 OHCHR (a), op.cit., p. 5.

50 Ibidem.

51 S.R. Maxwell, p. 6-7.
} 
leveled by various governments regarding Duterte's controversial clashes with drug cartels and potential human rights

Figure 2. Perceived severity of drug problem: own town and entire Philippines
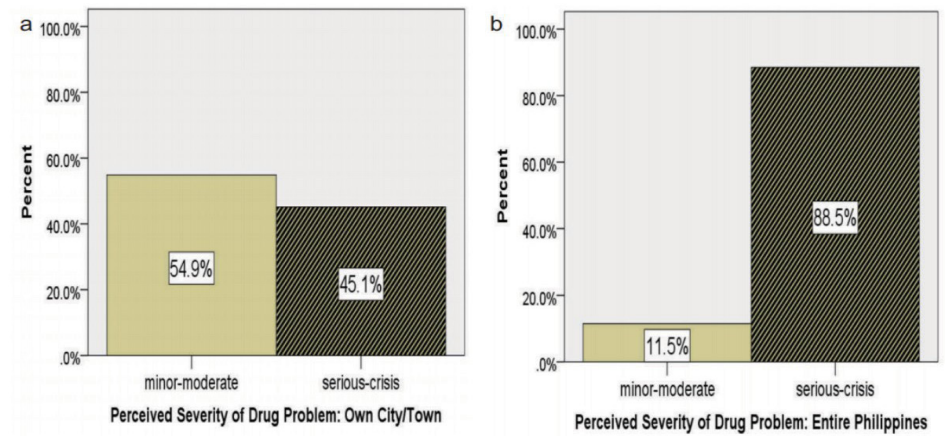

Source: S.R. Maxwell, p. 7.

Figure 3. Rodrigo Duterte and his war on drugs receive positive reviews from Filipinos

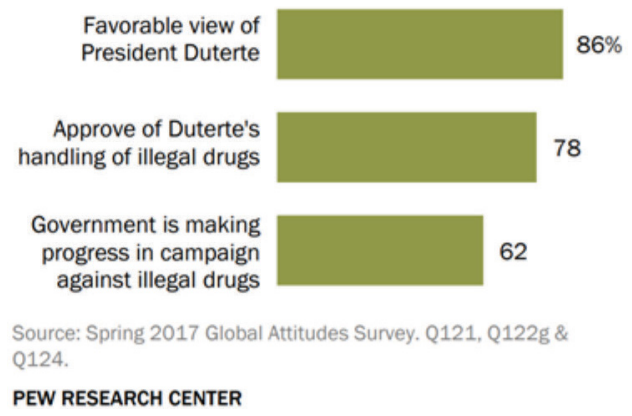

Source: J. Poushter, C. Bishop, People in the Philippines Still Favor U.S. Over China, but Gap Is Narrowing, "Pew Research Center" 2017, p. 4 [access: 12.11.2020]. 
Figure 4. Views of President Rodrigo Duterte

\section{Majority believe Philippine government is making progress in its war on drugs}

Do you think that the Philippine government is making progress in its campaign against illegal drugs, losing ground, or are things about the same as they have been in the past?

Making progress

Same as Losing the past ground

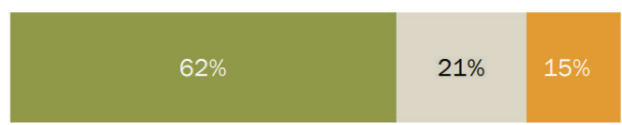

Source: Spring 2017 Global Attitudes Survey. Q124.

PEW RESEARCH CENTER

Source: J. Poushter, C. Bishop, p. 5.

potential human rights violations. Approximately $86 \%$ have a favorable view of Duterte himself, 78\% support his handling of the illegal-drugs issues and 62\% say that the Philippine government is making progress in its anti-drug campaign $^{52}$ (see Figure 3 and 4). Meanwhile, a survey by Pulse Asia in September 2017, not much different from Pew Research Center, reveals that $88 \%$ of Filipinos support the administration's campaign against illegal drugs, even though $73 \%$ believe that extrajudicial killings occur in its conduct ${ }^{53}$. According to Juego, there are multiple psychological factors explaining why there is popular support for the anti-drug offence. People at large fear for their individual

52 J. Poushter, C. Bishop, p. 136.

53 B. Juego, The Philippines 2017: Duterte-led Authoritarian Populism and Its Liberal-Democratic Roots, "Asia Maior: The Journal of the Italian think tank on Asia” 2017, Vol. XXVIII, p. 135 
selves and for their families being victimised by illegal drug abuse and drug-related crimes. Some support the campaign strongly as an expression of their own hatred, having been themselves, or their family members, victimised by illegal drug traffickers and users. Other supporters are in denial of their own past illegal drug use. Frustration and anger abound with regard to the failure of previous administrations to seriously address the problems of illegal drugs and criminality. The survey suggests how much more Filipinos care about prioritising a sense of public security and personal safety vis-à-vis drug-related crimes. High trust is given to the perception of Duterte's political will and the necessity for a strongman to deal with the complex apparatus of the illegal drug industry ${ }^{54}$.

As an argument for legitimacy, Duterte tried to show the public that the elites who opposed him were corrupt. In 2017, a leading critic of Philippine President Rodrigo Duterte, Senator Leila de Lima, has been arrested on drug trafficking charges. De Lima is accused of receiving money from detained drug lords. De Lima faces three drug-related charges, including one that states she received money from drug dealers in the country's prisons of approximately 5 million Philippine pesos (\$99,850 / 94,380 euros) between 2010-2016 ${ }^{55}$. De Lima's arrest has reinforced public confidence and also fear of Duterte as well. But, Duterte claims that he represents the majority, not the few. Duterte has also frequently criticized human rights defenders and the con-

54 Ibidem, p. 136.

55 DW.COM, Philippine Senator Leila de Lima arrested on illegal drug charges, 2017, https://www.dw.com/en/philippine-senatorle-ila-de-lima-arrested-on-illegal-drug-charges/a-37696588 [access: 12.11.2020]. 
cept of human rights, stating that "your concern is human rights, mine is human life"56. On August 16, 2017, Duterte alleged that human rights organizations criticized the 'war on drugs' to protect drug criminals. "When it comes to criminals, you [human rights organizations] will proclaim, 'human rights violations' [to protect them]." On March 26, 2018, Presidential Spokesperson Harry Roque stated that the government did not discount the possibility that some human rights groups had become unwitting tools of drug lords to hinder the strides made by the administration. The statement was issued after Foreign Affairs Secretary, Alan Peter Cayetano claimed on March 25, 2018, that some human rights groups were being unwittingly used by drug lords to destabilize the government and discredit its 'war on drugs $^{57}$. With little resistance to his rule, Duterte's violence against human rights has increased. Duterte has targeted his domestic enemies with overheated rhetoric. Since February 2017, Senator Leila de Lima has been jailed on politically motivated drug charges filed against her in apparent retaliation for leading a Senate inquiry into the "drug war" killings. Duterte responded with a personal attack, accusing her of "sexual escapades" with her driver who had collected payoffs linked to illegal drugs while his allies removed her as head of the senate investigative committee with the lower house setting up several investigations of de Lima instead ${ }^{58}$. In September, Duterte ordered the arrest of a colleague of

56 G.K. Cabico, HRW: Drug war, attacks vs critics 'deepened' rights crisis in Philippines, https://www.philstar.com/headlines/2019/01 /18/1886167/hrw-drug-war-attacks-vs-critics-deepened-rights-crisisphilippines [access: 12.11.2020].

57 D. Louys, p. 9.

58 Human Rights Watch (b), p. 468. 
de Lima's, Senator Antonio Trillanes IV, by revoking his amnesty, forcing him to remain at the Senate premises for weeks. In October, a Manila court dismissed the government's petition to issue the arrest warrant against Trillanes. Trillanes has been Duterte's most vocal critic since de Lima, accusing the president and his family of corruption ${ }^{59}$. The most dramatic event was the Supreme Court's removal of its own chief justice, Maria Lourdes Sereno, following a petition by the government. The case was extraordinary because the ouster had sidestepped the constitutional remedy of impeachment, the traditional way of removing high officers of the state, including the chief justice. Sereno was an outspoken critic of President Duterte's war on illegal drugs. The Supreme Court's actions and inactions in these salient cases suggest a judiciary largely unwilling to rule against the president. In choosing self-restraint, the Supreme Court has left Philippine democracy to backslide. In the cases of De Lima, Trillanes, and Sereno, the court effectively narrowed political competition. It allowed the administration to arrest or oust opposition figures from both the legislative and judicial branches ${ }^{60}$.

Another factor that is influential in determining popular support for the violation of human rights by Duterte is the economic stability. Based on Pew research survey in 2017, 80\% of Filipinos are satisfied with Duterte's handling of the economy. During the duterte administration, the Philippines economic growth reached above 6\%. In 2017,

59 Ibidem.

60 E.J. Ibarra, Is There Judicial Independence in Duterte's Philippines?, 2019, https://www.democratic-erosion. com/2019/12/02/ is-there-judicial-independence-in-dutertes-philippines/ [access: 12.11.2020]. 
GDP reached the point of 7.4\%. Even though it experienced a decline in the following year, until 2019, the Philippine economic growth was still at the level of above $6 \%$. In the third quarter of 2019, economic growth was at $6.2 \%$ (see Figure. 5). Economic stability provides Duterte with an opportunity to finance social programs such as the Pantawid Pamilyang Pilipino Program (4Ps) - the Conditional Cash Transfer Program, health insurance, education security and even the Philippine Police's salary increases.

Figure 5. Quarterly growth rate of real gross domestic product and gross national income, 2015 Q1-2019 Q3

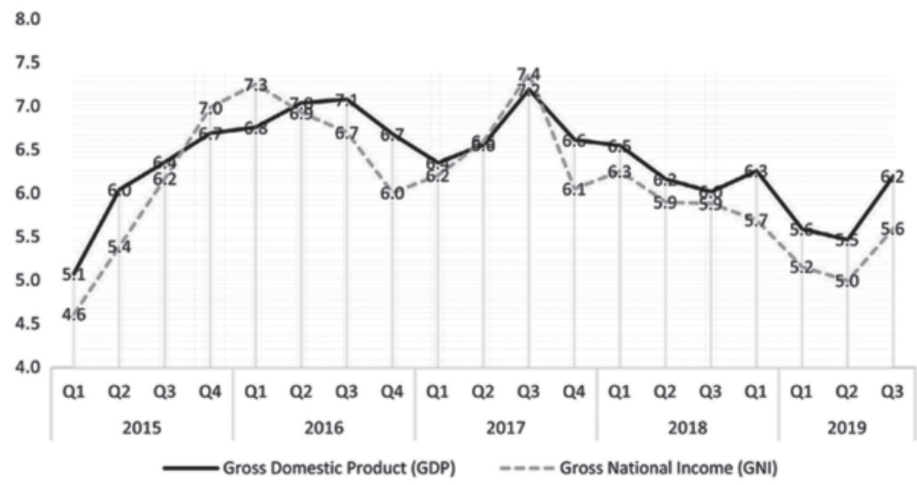

Source of raw data: Philippine Statistics Authority 2019

Source: J.J. Capuno, Dutertenomics: Populism, Progress, and Prospects, "Asian Economic Policy Review" 2020, p. 13 [access: 12.11.2020].

Figure 6 shows a sharp increase in the financing of social services for Filipinos in 2016 and 2017, reaching over 1 trillion pesos (a significant shift in the focus on the social sector). In the health sector, there was a substantial rise, which amounted to about $20 \%$ of the cost of social expenditure. A substantial amount of funding for education services, 
namely about $50 \%$, was also allocated by Duterte ${ }^{61}$. Filipino students received educational assistance up to university level in the Duterte period. The less fortunate people, meanwhile, get cash transfers through the $4 \mathrm{P}$ scheme.

Figure 6. Sectoral Distribution of Public Spending in the Philippines, 2008-2017

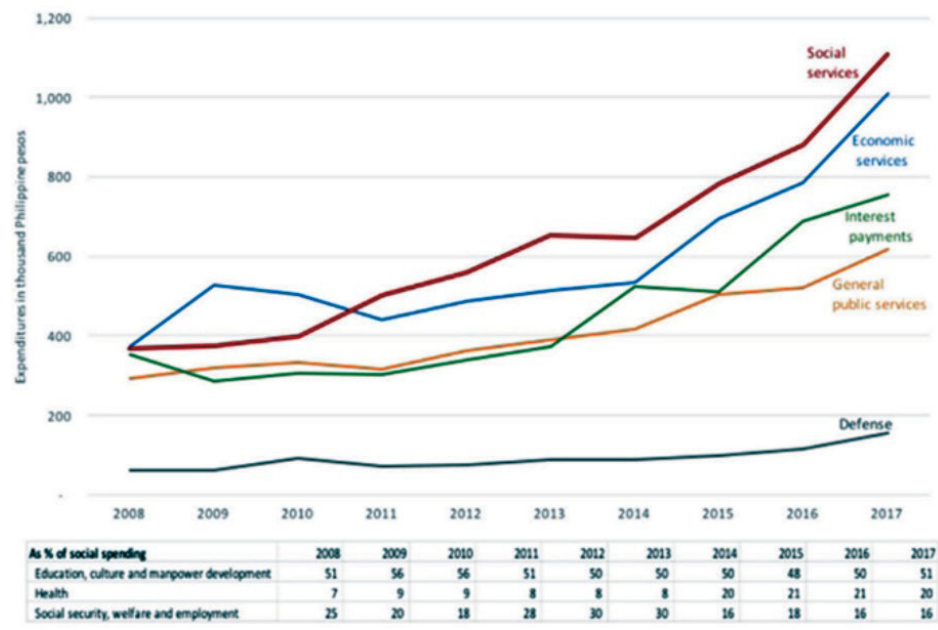

Source: C.G. Ramos, Change without Transformation: Social Policy Reforms in the Philippines under Duterte, "Development and Change" 2020, 51(2), p. 496 [access: 12.11.2020].

The most important change has occurred in the Philippine National Police (PNP) salary. In 2018, Duterte has fulfilled his campaign promise to increase the salaries of police officers and soldiers when he signed into law the Congress Joint Resolution modifying the Base Pay Schedule for Military and Uniformed Personnel (MUP) on January 9 at

61 C.G. Ramos, p. 496. 
Malacañang Palace after it was passed by the House of Representatives as House Joint Resolution 18 on Dec. 11, 2017 and adopted by the Senate as an amendment to Senate Joint Resolution 11 on Dec. 13, 2017 ${ }^{62}$. Congress Joint Resolution (JR) no. 1, s. 2018 doubles the base pay of a Police Officer (PO) I in the Philippine National Police (PNP) or a Private in the Armed Forces of the Philippines (AFP), and equivalent ranks in the Bureau of Jail Management and Penology (BJMP), Bureau of Fire Protection (BFP), Philippine Public Safety College (PPSC), Philippine Coast Guard (PCG), and the National Mapping and Resource Information Authority (NAMRIA). A PO I and those with equivalent rank will enjoy a $100 \%$ increase, resulting to a monthly base pay of P29,668 (616.840 USD). Overall, the salary adjustments, which took effect on January 1, 2018, results to a 58.7 percent average increase for all MUP ranks ${ }^{63}$. (See table 3).

The salary of the PNP, according to Duterte, is extremely low. Therefore, the government needs adjustments to be made. This rise in wages was accompanied by the police's commitment to rid the Philippines of all forms of criminals, especially the battle against illegal drugs. The relationship between Duterte and the PNP indicates the case of the ally principle. Police have an intrinsic motivation to address the Duterte capitalizes on this motivation, often telling them to "clean up the streets." This creates a norm within the PNP where "police officers try so hard to please the President."

62 A. Morallo, Duterte signs resolution hiking military, police pay, 2018, https://www.philstar.com/head-lines/2018/01/09/1776288/ duterte-signs-resolution-hiking-military-police-pay [access: 12.11.2020].

63 Pia.Gov.Ph, President Duterte fulfills campaign promise, doubles salaries of cops, soldiers 2018, https://pia.gov.ph/news/articles/1003914 [access: 12.11.2020]. 
Table 3. Modified Base Pay Schedule For Military and Uniformed Personnel Beginning January 1, 2018

\section{Modified Base Pay Schedule \\ For Military and Uniformed Personnel \\ Beginning January 1, 2018}

\begin{tabular}{|c|c|c|c|c|c|}
\hline \multirow[b]{2}{*}{ DND } & \multicolumn{2}{|c|}{ DILG } & \multirow[b]{2}{*}{ PCG } & \multirow[b]{2}{*}{ NAMRIA } & \multirow{2}{*}{$\begin{array}{l}\text { Monthly } \\
\text { Base Pay }\end{array}$} \\
\hline & $\begin{array}{l}\text { BJMP and } \\
\text { BFP }\end{array}$ & $\begin{array}{l}\text { PNP and } \\
\text { PPSC }\end{array}$ & & & \\
\hline $\begin{array}{l}\text { Candidate } \\
\text { Soldier }\end{array}$ & & & $\begin{array}{c}\text { Candidate } \\
\text { Coastguardsman }\end{array}$ & & P 18,587 \\
\hline Private & $\begin{array}{c}\text { Fire/ } \\
\text { Jail Officer I }\end{array}$ & Police Officer I & $\begin{array}{c}\text { Apprentice } \\
\text { Seaman/Seaman } \\
\text { Third Class }\end{array}$ & $\begin{array}{l}\text { Apprentice } \\
\text { Seaman/Seaman } \\
\text { Third Class }\end{array}$ & 29,668 \\
\hline $\begin{array}{l}\text { Private First } \\
\text { Class }\end{array}$ & & & $\begin{array}{c}\text { Seaman } \\
\text { Second Class }\end{array}$ & $\begin{array}{c}\text { Seaman } \\
\text { Second Class }\end{array}$ & 30,261 \\
\hline Corporal & $\begin{array}{c}\text { Fire/ } \\
\text { Jail Officer II }\end{array}$ & $\begin{array}{c}\text { Police } \\
\text { Officer II }\end{array}$ & $\begin{array}{c}\text { Seaman } \\
\text { First Class }\end{array}$ & $\begin{array}{l}\text { Seaman } \\
\text { First Class }\end{array}$ & 30,867 \\
\hline Sergeant & & & Petty Officer III & Petty Officer III & 31,484 \\
\hline Staff Sergeant & $\begin{array}{c}\text { Fire/ } \\
\text { Jail Officer III }\end{array}$ & $\begin{array}{c}\text { Police } \\
\text { Officer III }\end{array}$ & Petty Officer II & Petty Officer II & 32,114 \\
\hline $\begin{array}{l}\text { Technical } \\
\text { Sergeant }\end{array}$ & & & Petty Officer I & Petty Officer I & 32,756 \\
\hline Master Sergeant & $\begin{array}{l}\text { Senior Fire/ } \\
\text { Jail Officer I }\end{array}$ & $\begin{array}{c}\text { Senior Police } \\
\text { Officer I }\end{array}$ & Chief Petty Officer & Chief Petty Officer & 33,411 \\
\hline $\begin{array}{l}\text { Senior Master } \\
\text { Sergeant }\end{array}$ & $\begin{array}{l}\text { Senior Fire/ } \\
\text { Jail Officer II }\end{array}$ & $\begin{array}{l}\text { Senior Police } \\
\text { Officer II }\end{array}$ & $\begin{array}{l}\text { Senior Chief } \\
\text { Petty Officer }\end{array}$ & $\begin{array}{l}\text { Senior Chief } \\
\text { Petty Officer }\end{array}$ & 34,079 \\
\hline $\begin{array}{l}\text { Chief Master } \\
\text { Sergeant }\end{array}$ & $\begin{array}{l}\text { Senior Fire/ } \\
\text { Jail Officer III }\end{array}$ & $\begin{array}{l}\text { Senior Police } \\
\text { Officer III }\end{array}$ & $\begin{array}{l}\text { Master Chief } \\
\text { Petty Officer }\end{array}$ & $\begin{array}{l}\text { Master Chief } \\
\text { Petty Officer }\end{array}$ & 34,761 \\
\hline $\begin{array}{c}\text { First Chief } \\
\text { Master Sergeant }\end{array}$ & $\begin{array}{l}\text { Senior Fire/ } \\
\text { Jail Officer IV }\end{array}$ & $\begin{array}{l}\text { Senior Police } \\
\text { Officer IV }\end{array}$ & $\begin{array}{l}\text { First Master Chief } \\
\text { Petty Officer }\end{array}$ & $\begin{array}{l}\text { First Master Chief } \\
\text { Petty Officer }\end{array}$ & 35,456 \\
\hline Cadet & & Cadet & Cadet & & 35,456 \\
\hline $\begin{array}{l}\text { Probationary } \\
\text { Second } \\
\text { Lieutenant }\end{array}$ & & & $\begin{array}{l}\text { Probationary } \\
\text { Ensign }\end{array}$ & & 35,456 \\
\hline $\begin{array}{l}\text { Second } \\
\text { Lieutenant }\end{array}$ & & & Ensign & Ensign & 39,356 \\
\hline First Lieutenant & Inspector & Inspector & $\begin{array}{l}\text { Lieutenant } \\
\text { Junior Grade }\end{array}$ & $\begin{array}{l}\text { Lieutenant } \\
\text { Junior Grade }\end{array}$ & 43,685 \\
\hline Captain & Senior Inspector & Senior Inspector & $\begin{array}{l}\text { Lieutenant } \\
\text { Senior Grade }\end{array}$ & $\begin{array}{c}\text { Lieutenant } \\
\text { Senior Grade }\end{array}$ & 49,801 \\
\hline Major & Chief Inspector & Chief Inspector & $\begin{array}{l}\text { Lieutenant } \\
\text { Commander }\end{array}$ & $\begin{array}{l}\text { Lieutenant } \\
\text { Commander }\end{array}$ & 54,799 \\
\hline $\begin{array}{l}\text { Lieutenant } \\
\text { Colonel }\end{array}$ & Superintendent & Superintendent & Commander & Commander & 61,375 \\
\hline Colonel & $\begin{array}{c}\text { Senior } \\
\text { Superintendent }\end{array}$ & $\begin{array}{c}\text { Senior } \\
\text { Superintendent }\end{array}$ & Captain & Captain & 68,740 \\
\hline $\begin{array}{l}\text { Brigadier } \\
\text { General }\end{array}$ & $\begin{array}{c}\text { Chief } \\
\text { Superintendent }\end{array}$ & $\begin{array}{c}\text { Chief } \\
\text { Superintendent }\end{array}$ & Commodore & Commodore & 76,988 \\
\hline Major General & Director & Director & Rear Admiral & Rear Admiral & 86,227 \\
\hline & & & Vice Admiral & Vice Admiral & 96,574 \\
\hline $\begin{array}{l}\text { Lieutenant } \\
\text { General }\end{array}$ & & $\begin{array}{l}\text { Deputy Director } \\
\text { General }\end{array}$ & Admiral & Admiral & 108,163 \\
\hline General & & Director General & & & 121,143 \\
\hline
\end{tabular}

Source: National Budget Circular No. 574, https://www.dbm.gov.ph/2082018/423-national-budget-circular-no-574 [access: 12.11.2020].

Due to such high expectations within the PNP, this creates a standard in the PNP. Because of such strong norms within the PNP, officers who disagree with the President may be 
afraid to be labeled as an enemy and then lose their jobs or risk being a target themselves ${ }^{64}$.

\section{Conclusion}

Observing the relationship between populism and human rights in the Philippines reinforces the assumption that populism is a threat to human rights. The case of the Philippines reveals a number of variables that give populist leaders great opportunities to violate human rights. First, public trust in leadership. 86.6 percent of the Filipinos view Duterte positively. Second, the discursive construction of national threats. Duterte was able to make a statement that the narcotics problem was a national disaster, so $86 \%$ supported his policy of extrajudicial killing. Third, the lack of internal and external threats contribute to the violation of human rights in the Philippines. Duterte's shrewdness in silencing his political opponents and engaging the police and the military to support his policies has smoothed out the policy of narcotics warfare.

Finally, economic stability enhances public confidence in Duterte and benefits Duterte from financing social programs such as 4P, health grant and education grant, and even doubles the salaries of the Philippine police. This article identified an important variable that can be considered in the understanding of the relationship between populism and human rights, namely economic stability, which shows a strong correlation in the promotion of human rights viola-

64 A. Baguios, R. Kong, L. Phillips, A. Mahon, The political economy of Duterte's war on drugs, https://blogs.lse.ac.uk/internationaldevelopment/2019/11/07/the-political-economy-of-dutertes-war-on-drugs/ [access: 12.11.2020]. 
tions in the Philippines. Financial stability also has a strong influence on silencing and even co-opting political opponents to support authoritarian populism.

\section{Bibliography}

Alston P., The Populist Challenge to Human Rights, "Journal of Human Rights Practice" 2017, No. 9.

Amnesty International, Assessment of The Human Rights Situation in The Philippines Against Objective Criteria for Action by The Un Human Rights Council, https://www. amnesty.org/download/Documents/IOR4004662019EN GLISH.PDF.

Ayyub R., What a Rising Tide of Violence Against Muslims in India Says About Modi's Second Term, https://time. com/5617161/india-religious-hate-crimes-modi/.

Baguios A., Kong R., Phillips L., Mahon A., The political economy of Duterte's war on drugs, https://blogs.lse.ac.uk/ internationaldevelopment/2019/11/07/the-politicaleconomy-of-dutertes-war-on-drugs/.

BBC.COM, Populist leaders' encourage rights abuses, $\mathrm{Hu}$ man Rights Watch says, https://www.bbc. com/news/ world-38593496.

Bilkova V., Populism and Human Rights, [in:] Netherlands Yearbook of International Law 2018 - Populism and International Law, eds. J.E. Nijman, G Werner, The Hague 2019.

Bonikowski B., Gidron N., Multiple Traditions in Populism Research, "APSA Comparative Politics Newsletter" 2016, No. 26 (12).

Braun J.P., Populism and Human Rights in Theory and Prac- 
tice: Chavez's Venezuela and Fujimori's Peru. Thesis, https://digitalcommons.unl.edu/poliscitheses/9, 2011.

Cabico G.K., HRW: Drug war, attacks vs critics 'deepened' rights crisis in Philippines, January 18, 2019, https://www. philstar.com/headlines/2019/01/18/1886167/hrw-drugwar-attacks-vs-critics-deepened-rights-crisis-philippines.

Capuno J.J., Dutertenomics: Populism, Progress, and Prospects, "Asian Economic Policy Review" 2020.

Cook M., Salazar L., The Differences Duterte Relied Upon to Win, "ISEAS - Yusof Ishak Institute" 2016, No. 34.

Coupal Y., Macroeconomics of populism in Venezuela, May 2003, http://citeseerx.ist.psu.edu/viewdoc/downlo ad?d oi $=10.1 .1 .547 .6434 \&$ rep=rep1\&type $=$ pdf.

Dornbusch R., Edwards S., The Macroeconomics of populism in Latin America, Chicago 1991.

DW.COM, Philippine Senator Leila de Lima arrested on illegal drug charges, https://www.dw.com/en/philippine-senator-leila-de-lima-arrested-on-illegal-drugcharges/a-37696588.

Human Rights Watch [a], World Report 2017: Demagogues Threaten Human Rights, https://www.hrw.org/news/ 2017/01/13/world-report-2017-demagogues-threatenhuman-rights.

Human Rights Watch [b], World Report 2019, https://www. hrw.org/sites/default/files/world_report_download/hrw_ world_report_2019.pdf.

Ibarra E.J., Is There Judicial Independence in Duterte's Philippines?, https://www.democratic-erosion.com/2019/12/02 /is-there-judicial-independence-indutertes-philippines/. Johnson D.T., Fernquest J., Governing through Killing: The War on Drugs in the Philippines, "Asian Journal of Law and Society" 2018, No. 5. 
Juego B., The Philippines 2017: Duterteled Authoritarian Populism and Its Liberal-Democratic Roots, "ASIA MAIOR, The Journal of the Italian think tank on Asia" 2017, Vol. XXVIII.

Kenny P.D., Populism in Southeast Asia, Cambridge 2019.

Laclau E., On Populist Reason, London 2005.

Levitsky S., Loxton J., Populism and competitive authoritarianism in the Andes, "Democratization" 2013, Vol. 20, No. 1.

Locke J., Macpherson C.B., Second Treatise of Government. Indianapolis 1980.

Louys D., The Observatory: I'll Kill You Along with Drug Addicts: President Duterte's war on human rights defenders in the Philippines, 2019, https://www.omct.org/en/ resources/reports/ill-kill-you-along-with-drug-addictspresident-dutertes-war-on-human-rights-defenders-inthe-philippines.

Maxwell S.R., Perceived threat of crime, authoritarianism, and the rise of a populist president in the Philip - pines, "International Journal of Comparative and Applied Criminal Justice" 2018.

Morallo A., Duterte signs resolution hiking military, police pay, https://www.philstar.com/head-lines/2018/01/09/ 1776288/duterte-signs-resolution-hiking-military-police-pay.

Mudde C., Populist Radical Right Parties in Europe, Cambridge 2007.

National Budget Circular No. 574, https://www.dbm.gov. ph/208-2018/423-national-budget-circular-no-574.

Neuman G.L., Populist Threats to the International Human Rights System, https://www.cambridge.org/core/services/ aop-cambridge-core/content/view/DFB3520DD9D455 
FC66DCF1986243AE7B/9781108485494c1_1-19.pdf/ populist_threats_to_the_international_human_rights_ system.pdf.

OHCHR[a], Report of the United Nations High Commissioner for Human Rights on the situation of human rights in the Philippines, A/HRC/44/22, 29.06.2020, https://www.ohchr.org/Documents/Countries/PH/ Philippines-HRC44-AEV.pdf.

OHCHR[b], 44 th session of the Human Rights Council Enhanced interactive dialogue on the situation of human rights in the Philippines, https://www.ohchr.org/EN/ NewsEvents/Pages/DisplayNews. aspx?NewsID $=26016 \&$ LangID $=\mathrm{E}$.

Pernia R.A., Human Rights in a Time of Populism: Philippines under Rodrigo Duterte, "Asia-Pacific Social Science Review" 2019, No. 19 (3).

Pia.Gov.Ph., President Duterte fulfills campaign promise, doubles salaries of cops, soldiers, https://pia.gov.ph/news/ articles/1003914.

Poushter J., Bishop C., People in the Philippines Still Favor U.S. Over China, but Gap Is Narrowing, "Pew Research Center" 2017.

Ramos C.G., Change without Transformation: Social Policy Reforms in the Philippines under Duterte, "Development and Change" 2020, Vol. 51 (2).

Roberts K.M., Latin America's Populist Revival, "SAIS Review of International Affairs" 2007, Vol. 27 (1).

Roth K., The Dangerous Rise of Populism: Global Attacks on Human Rights Values, "Journal of International Affairs”, The Next World Order: Special 70 ${ }^{\text {th }}$ Anniversary Issue, 2017.

Sianipar I.M.J., Kebangkitan Populisme di Amerika Latin, 
“The rise of Populism in Latin America]", Thesis, Yogyakarta 2012.

Simangan D., Is the Philippine "War on Drugs" an Act of Genocide?, "Journal of Genocide Research" 2017.

The Jakarta Post, Crowds rally in Hong Kong after activists jailed, 20.08.2017, https://www.thejakartapost. com/ news/2017/08/20/crowds-rally-in-hong-kong-after-activists-jailed.html.

Timberman D.G., Philippine Politics Under Duterte: A Midterm Assessment, https://carnegieendowment.org/2019/ 01/10/philippine-politics-under-duterte-midterm-assessment-pub-78091.

Tolbert D., Duterte's 'War on Drugs' Brings Dictatorship Methods Back to the Philippines, https://www.ictj.org/ news/duterte-philippines-drug-dictatorship.

United Nations[a], Bachelet renews call for accountability in Philippines war on illegal drugs, https://news.un.org/en/ story/2020/06/1067462.

United Nations (b), Global Issues: Human Rights, https:// www.un.org/en/global-issues/human-rights.

Weyland K., Clarifying a Contested Concept: Populism in the Study of Latin American Politics, "Comparative Politics", October 2001, Vol. 34, No. 1.

\footnotetext{
Abstract

The aim of this article is to explain the relationship between populism and human rights. Many scholars argue that there is a contra diction between populism and human rights. The Philippines is an example of a number of cases. The emergence of a populist leader, Rodrigo Duterte, devastated the human rights situation in the Philippines. Since being elected president in 2016, Duterte has committed
} 
a number of human rights violations, including the murder of drug dealers and addicts, media blocking, and attacking human rights defenders and so many others. Using Bilkova's as well as Braun's work on populism and human rights, this article seeks to find factors that contribute to making populism contradict human rights in the Philippines. The paper found that public trust in leadership, the discursive construction of national threats, the lack of internal and external threats, and economic stability contribute to human rights abuses in the country.

Keywords: Populism, Human Rights, The Philippines, Duterte 


\section{Neo-Developmental State and Indonesia's Human Right Problems in the Joko Widodo Era}

\section{Introduction}

Joko Widodo (Jokowi), the $7^{\text {th }}$ President of the Republic of Indonesia, is considered a breath of fresh air in Indonesian politics. For the first time, Indonesia is led by a figure with no political affinity for political parties. Jokowi becomes a president due to his track record as a successful local leader. Before becoming a president, he successfully led the city of Surakarta (Central Java) as the Mayor and became the Governor of DKI Jakarta with a positive track record. He is considered a populist leader with a strong commitment to transparency and eradicating corruption.

Jokowi also presents himself as a populist figure coming with an agenda for people's economic development. This populist policy is deemed to be a different precedent compared to its predecessors and at the same time risking Indonesia's position regionally. Farish Noor, a researcher at the S. Rajaratnam School of International Studies based in Singapore, saw Jokowi as inclined to bet on his foreign policy in Southeast Asia by moving populist policies at home to satisfy his voters. Noor considered it to damage ASEAN 
solidarity formed for a long time. ${ }^{1}$ Jokowi's populist move is also presumed to run the risk of sparking tensions with neighboring countries at a time when ASEAN seeks to form closer communities. ${ }^{2}$

Liberal democratic politics and Jokowi are likely to revive the developmental state model in development policies. Several circles consider populist politics to have led Jokowi to be a political leader without the insignia of power as the previous leaders. He does not gain power through the consensus of elites like Sukarno, through military intervention like Suharto, through resignation from incumbents like Habibie, through indirect elections like Abdurahman Wahid, or controversial 'impeachment' like Megawati. ${ }^{3}$ Jokowi was born from the space of liberal democracy that Indonesia chose as a post-New Order political system. However, unlike Yudhoyono, who is military-based and comes from a political party's power, Jokowi is described as a product of oligarchic politics. All these political determinants will influence Jokowi's development policies in Indonesia today.

One of the critical features of Jokowi's development policy is infrastructure development. He seems ambitious and believes that Indonesia's economic growth will be determined by infrastructure quality. On many occasions, he has been concerned about developing various infrastructure projects such as highways, ports and the relocation of Indonesia's capital city from Jakarta to Kalimantan. He is also

1 P. Parameswaran, Is Indonesia turning away from ASEAN under jokowi? early signs point to a far, more bilateral, domestic-oriented foreign policy, "The Diplomat", 18.12.2014.

2 Ibidem.

3 M. Mietzner, Reinventing Asian Populism: Jokowi's Rise, Democracy and Political Contestation in Indonesia, Hawai 2015. 
aggressively developing Indonesian tourist destinations as "world-class destinations". Several exotic places in Indonesia, such as Labuhan Bajo, Lake Toba and Komodo Island, are not spared from his developmental projects and will be used as premium tourist spots on an international scale. ${ }^{4}$

\section{From the Militarization of Development to the Oligarchy of Development}

Jokowi is the $7^{\text {th }}$ President of Indonesia who has taken office since October 20, 2014. He is also the $5^{\text {th }}$ President of Indonesia since entering the Reform era and liberal democracy. His development policy platform paying attention to infrastructure development relies on foreign debt. After the New Order, the impact of economic liberalization on democratic life has risen an explosion of public participation in political life. The word often used by observers and the media to describe this phenomenon is "euphoria," referring to the explosion of participation. The political system and the general election management system have fundamentally changed.

During the New Order era, economic liberalization was not followed by political liberalization, resulting in a developmental state format. After the New Order phase, Indonesia entered a transitional phase toward democracy. Since then, the liberalization process has taken place on both economic and political tracks simultaneously. After Suharto, political life in Indonesia underwent a radical change. Since Suharto stepped down, there have been five presidential changes in less than a decade.

4 Berebut komodo (scramble for komodo), „Tempo Magazine”, 1.02.2021. 
The Reformation period after the New Order's fall in 1998 indicated a systemic change or state transformation. The radical changes described in the previous section have occurred in the political system. However, one variable seems to be ongoing, namely the capital variable in the form of the growing pressure of the country's global economic structure. As it is later seen, the state neoliberalism process is closely related to the amount of aid resulting from agreements with economic institutions such as the IMF.

The neoliberal regime's democratization projects have begun to be intensively carried out to form an effective government and create a civil society compatible with the state's efforts to implement neoliberal policies or spread the ideas and values of cosmopolitan democracy. This change in perspective can be seen from the ideas emerging in various multilateral agency projects. Issues of "good governance" began to become projects initiated by several international institutions after the 1997 economic crisis. Institutions such as the World Bank, the United Nations Development Program (UNDP), and the Asian Development Bank began to spread values and ideas around this "good governance."

Some observers asserted that the two phenomena - economic and political liberalization - have a causal relationship with each other. In terms of the qualifications of the actors, the liberal democratic process in Indonesia is seen as merely a "new stage for the re-emergence of old actors", both from the perspective of the re-emergence of old conglomerates and old politicians. They enter the political economy

5 I. Yoichiro, Economic Governance and Economic Performance in Developing Countries, "Forum of International Development Studies", 19.10.2001. 
arena in new businesses such as the media and are involved in new political parties. Christian Chua described the relationship between capital and modern democracy in Indonesia: "Post-Suharto Indonesian democracy has thus provided the capital with a powerful means and influence on politics and civil society."

The critical difference between the developmental state's characters in the New Order era and the Jokowi era lies in several things. First, during the New Order era, the military's position as an institution was very dominant in Indonesian politics. The selection of political elites took place homogeneously, while development policies were very Jakartacentric. However, in the Jokowi era, the developmental state grows in a democratic political arena where party power is enormous in determining development blueprints. Political parties produce oligarchic elites, which then form the development oligarchy. Having transactional characters, the democratic development of the Joko Widodo era is also very transactional. As a result, the oligarchy of development has emerged. Second, during the New Order era, the developmental stage gave birth to a centralized model, while the Jokowi era has given birth to relative decentralization, where local governments play a large role in development policies. Third, during the New Order era, civil society's power was silenced by military forces as an institution. Conversely, the Jokowi era has given it wide space but experiences political and structural obstacles from a relatively strong political oligarchy.

6 C. Chua, Capitalist Consolidation, Consolidated Capitalist: Indonesia's Conglomerates between Authoritarianism and Democracy, [in:] Democratization in Post-Suharto Indonesia, Bunted and Ufen (eds), London 2009. 
Even though the Jokowi era possesses a democratization process in political life, it is not followed by deepening democracy. The international community has widely praised the emergence of the political liberalization process in post-New Order Indonesia as a prominent development of democracy in developing countries. Even as the largest Muslim country in the world, Indonesia is touted as a Muslim country with the most advanced level of democracy. International institutions will immediately focus on strengthening and deepening Indonesian democracy. Nevertheless, democratic politics is increasingly marked by the emergence of a political bourgeoisie from the transactional political space, thus impacting the development process.

According to Aspirinall ${ }^{7}$, Indonesia receives substantial assistance from international institutions for democracy projects in the post-New Order era, showing a drastic increase. This assistance is aimed at civil society organizations (CSOs), and new government institutions considered the new pillars of democracy. One crucial issue that cannot be ignored in the developmental state of the Jokowi era is the emergence of oligarchic forces in the political life of the masses. Taking advantage of the democratic political space, radical groups from Islamic political forces during the New Order could be controlled by the state, obtaining free articulation. With all these developments, Jokowi seems to want to build a re-packaging model of New Order developmentalism, which culminates in how politics is directed to "maximize economic growth" and "minimize political participation". 2010 .

E. Asprinall, Assessing Democracy Assistance: Indonesia, Madrid

8 M. Mas'oed, Ekonomi dan struktur politik Orde Baru, 1966-1971 (Economy and of New Order Political Structure 1966-1971), Jakarta 1989. 
The concept of a developmental state is prevalent in East Asian countries. In this model, the state's position is powerful both as a planner and a development actor. This concept was proposed by Chalmers Johnson ${ }^{9}$, defining a developmental state as "a state that is focused on economic development and takes necessary policy measures to accomplish that objective... In states that were late to industrialize, the state itself led the industrialization drive, that is, it took on developmental functions".

Since the New Order, the tendency to aplicate a developmental state model has been chosen by Indonesia in an effort to build economic power based on centralism of power in the hands of the three main pillars of political power: President-Military-Bureaucracy. ${ }^{10}$ These three political forces form the model for corporatic development. Jokowi revived the developmental state model by paying great attention to infrastructure sector. In Jokowi's view, infrastructure development is needed by Indonesia today as an important pillar for eliminating inequality, reducing poverty and promoting economic growth. Infrastructure development is also part of Jokowi's efforts to to realize Nawacita doctrine (nine priority programs). ${ }^{11}$ In the context of infrastructure development, Jokowi is planning massive development. He plans to build $5000 \mathrm{~km}$ of railway, 2,600 km of road construction; 1,000 km toll roads, 49 dams; 24 seaports and power plants with a capacity of 35,000 megawats. ${ }^{12}$

9 C. Johnson, The Developmental State: Odyysey of a Concept, [in:] The Developmental State, ed. Woo-Cumings, Cornell 1999.

10 Ibidem.

11 E.Warburton, A new developmentalism in Indonesia?, ,Journal of Southeast Asian Economies" 2018, Vol. 35, No. 3, pp. 355-368.

12 W. Salim and S.D.Negara, Infrastructure development under 
In contrast to the pattern developed by the New Order which rely on military and bureaucratic power, Jokowi developed a developmental state through oligarchic and dynastic politics that developed in the space of liberal democracy. However, according to Greg Fealy's observation, Jokowi is basically reinstating Indonesia's military power as a dominant social and political forces. With this military power, Jokowi is actually bringing Indonesian politics into - what Fealy call as "repressive pluralism." ${ }^{13}$ If in the New Order's corporatic developmentalist patterns has produced ersatz capitalism. ${ }^{14}$ which made Indonesian capitalism different from Western and Japanese capitalism, while Jokowi's neo-developmentalism gave rise to an overbearing state ${ }^{15}$ where the state became an octopus regime that dominated both discourse producer and as development operators. The New Order provided a "red carpet" for international capitalist participation to sustain economic growth, however, in political life, patronage developed where the president's institution became the economic-political hub and giving rise to monopolies. Like the New Order, Jokowi also provided a very large space for international investors to support infrastructure development and re-positioned the president's office as oligarch fulcrum.

Although Indonesia's democracy index has increased, Jokowi is starting to be held hostage by oligarchic interests

the Jokowi administration: progress, challenges and policies, "Journal of Southeast Asian Economies" 2018, pp. 386-401.

13 G. Fealy, Jokowi in the covid-19 era: repressive pluralism, dynasticism and the overbearing state" "Bulletin of Indonesian Economic Studies", 2020 No. 3, p. 301-323.

14 Y. Kunio, The Rise of Ersatz Capitalism in South-East Asia, Oxford 1988.

15 Fealy, op.cit. 
supporting his power as a president. According to Baker, as a developmentalist president exhibiting 'impatience with legal complexity' and 'illiberal tendencies' consistent with his petit-bourgeois class origins. ${ }^{16}$ Jokowi also reinforces the country in cooperative ways. He becomes a developmentist who may not be ideologically oriented but tries to restrengthen the country and political stability as the most essential thing to drive economic development. Jokowi's policy, like Suharto's, places the non-economic sector as a secondary sector to improve economic welfare. ${ }^{17}$

\section{Developmentalism and Human Rights Problems}

A survey of Indonesian Political Indicators released in 2020 displays the Indonesian people's concern about the strengthening of the oligarchy in the Jokowi era and is considered to threaten citizens' freedom. Freedom is a fundamental element in democracy. The survey shows that 69.6 percent of respondents felt more afraid to voice their opinions on current issues publicly, 73.8 percent of respondents found it more difficult to hold public rallies and demonstrations, and 57.7 percent believed authorities had used excessive force against people who held political views diverging from the status quo (Indonesian Political Indicator 2020). Moreover, a survey from the Indonesia Legal Rountable (2017) depicts that the Jokowi era has decreased the human rights index compared to the previous regime. ${ }^{18}$

16 J. Baker, The Middle class president, „New Mandala”, 5.08.2016.

17 E. Warbuton, op.cit

18 ILR calls the decreasing value of Indonesia as a state of law „Gatra Weekly Magazine”, 17.10. 2017. 
Table 1. The Human Right Index in Indonesia (2012-2017)

\begin{tabular}{|l|l|}
\hline \multicolumn{1}{|c|}{ Year } & Index \\
\hline 2012 & 5.74 \\
\hline 2013 & 5.4 \\
\hline 2014 & 4.15 \\
\hline 2015 & 3.82 \\
\hline 2016 & 4.25 \\
\hline 2017 & 4.51 \\
\hline
\end{tabular}

Source: Indonesia Legal Roundtable (2017).

Jokowi's development focuses on developing infrastructures such as roads, ports, relocation of the capital and premium tourist destinations, required to accelerate Indonesia's economic acceleration. Unfortunately, behind all the lighthouse projects, a development oligarchy process occurs, resulting in the neglect of citizens' basic rights. The military does not have the power as an institution, but the militarization process is still ongoing in Indonesia through oligarchic networks supported by corporate and business power. Jokowi is also considered to have little concern over past human rights violations. Several human rights activists are pessimistic about his attention to resolve human rights issues, such as appearing in the "Kamisan Action" (Kamisan Silent Protest). It is a weekly action in several cities in Indonesia every Thursday. These protests have emerged since 2007, demanding the government to resolve past human rights issues, especially over the reformation events claiming many victims and missing people in Indonesia.

In environmental issues, Jokowi's infrastructure program is too siding with capital owners or corporations' power. Many environment defenders experienced violence and business silencing. In a recent report, the Institute for $\mathrm{Hu}-$ man Rights, The Institute for Policy Research and Advocacy, 
and a human rights organization (ELSAM) presented quite sad data. Through a report entitled "Under the Shadow of the State's and Company's Violence: Situation Report of the Environmental Human Rights Defenders (EHRDs) for November 2017-July 2018", ELSAM succeeded in mapping the actual situation of the EHRDs in Indonesia while identifying human rights violations attached to and accompanied them. The report found that within nine months in 2019, there were 254 victims of the act and threats of violence that beset the EHRDs. As much as 70\% of that number, namely 175 people, were individual victims. The family became the second-largest victim. A total of 71 (28\%) families lost their homes and were expelled from their living space. ${ }^{19}$

Investigations by Tempo Magazine January 2, 2021 edition in the "world-class tourism" projects of Komodo Island demonstrate Jokowi's strong developmenalist logic in environmental issues. ${ }^{20}$ As a result, local communities around the project must accept that Jakarta's corporate networks mostly carry out the Komodo Island tourism industry. According to Jale, ${ }^{21}$ the development of super-premium tourism and conservation developed by the Jokowi's government has eliminated the knowledge system of local communities for thousands of years and has been replaced by business logic, and Komodo has only become an industrial commodity to support investment from the tourism sector.

19 Elsam, Tahun-tahun penuh marabahaya (The Dangerous Years), https://elsam.or.id/menatap-tahun-tahun-penuh-marabahayalaporan-situasi-pembela-ham-atas-lingkungan-tahun-2019/ [access: 14.01.2021].

20 Berebut komodo (scramble for komodo), "Tempo Magazine”, 2.01.2021.

21 P. Jale, Komodo vs pembangunanisme kolonial" (komodo vs colonial developmentalism), “Tempo Weekly”, 2.012021. 


\section{Conclusion}

This paper has shown that the liberal democracy that Indonesia is now entering has fundamentally changed the spectrum and political diversity. However, the ambition of the state to build infrastructure in development shows a dual face of the state: on the one hand there are procedural political channels, but on the other hand there are development corporations where the domination of oligarchs has presented various problems such as obstruction of people's freedom, environmental problems and economic and social right. On the other hand, the re-emergence of a developmentalist character has birth in Indonesia, both political and social and economic, very elitist and at the same time abandoning the populist aspects as originally proposed by Jokowi.

\section{Bibliography}

Asprinall E., Assessing Democracy Assistance: Indonesia, Madrid 2010.

Berebut Komodo (Scramble for Komodo), „Tempo Weekly Magazine", 2.01.2021.

Christian C., Capitalist Consolidation, Consolidated Capitalist: Indonesia's Conglomerates between Authoritarianism and Democracy, [in:] Democratization in Post-Suharto Indonesia, eds. M. Bunted, A. Ufen, London, 2009. Elsam, Tahun-tahun penuh marabahaya (The dangerous years), https://elsam.or.id/menatap-tahun-tahun-penuhmarabahayalaporan-situasi-pembela-ham-atas-lingkungan-tahun-2019/. 
Elsam, Joint Stakeholder's Report on The Situation of The Right to Freedom of Expression, and Freedom of Associaton and Assembly in Indonesia, Jakarta 2016.

Elsam, Seeking for Justice: The Uncertain State of Protection for Environmental Human Rights Defenders in Indonesia Report on the Situation and Violation of Environmental Human Rights Defenders in Indonesia (August 2018-December 2018), Jakarta 2019.

Elsam, Environmental Human Rights Defenders in Indonesia Threatened By State and Company", Jakarta 2019.

Fealy G., Jokowi in the covid-19 era: repressive pluralism, dynasticism and the overbearing state, „Bulletin of Indonesian Economic Studies" 2020, No. 3.

ILR calls the decreasing value of Indonesia as a state of law, "Gatra Weekly Magazine”, 17.10.2017.

Ishihara Y., Economic Governance and Economic Performance in Developing Countries, paper pada Forum of International Development Studies, October 19, 2001.

Jale C., Komodo vs pembangunanisme kolonial (komodo vs colonial developmentalism), ,Tempo Weekly Magazine”, 2.01.2021.

Mas'oed M., Ekonomi dan Struktur Politik Orde Baru, 1966-1971 (Economy and New Order Political Structure 1966-1971), Jakarta 1989.

Mietzner M., Reinventing Asian Populism: Jokowi's Rise, Democracy and Political Contestation in Indonesia, ,EastWest Center Paper", Hawai 2015.

Parameswaran P., Is Indonesia turning away from ASEAN under Jokowi? early signs point to a far, more bilateral, domestic-oriented foreign policy, „The Diplomat”, 18.12. 2014.

Simpson B., Economic With Guns, Stanford 2008. 
The Developmental State, Cumings W (ed.), Cornell 1999. Warburton E., A New Developmentalism in Indonesia?, „Journal of Southeast Asian Economies” 2018, Vol. 35.

Salim W., Negara S.D., Infrastructure development under the Jokowi administration: progress, challenges and policies, „Journal of Southeast Asian Economies” 2018. Yoshihara K., The Rise of Ersatz Capitalism in South-East Asia, Oxford 1988.

\begin{abstract}
This paper seeks to explain the revival of a developmental state's idea in development policies in Indonesia during the Joko Widodo era. The idea of a developmental state is a development paradigm carried out by the Suharto regime during the New Order era. During the New Order era, the developmental state gave birth to an authoritative regime supported by military power. Meanwhile, during the Joko Widodo era, the developmental state grows together with the civilian regime with an oligarchic character. Both of these developmentalism eras bring significant implications for the emergence of human rights violations.
\end{abstract}

Keywords: developmental state, neo-developmental state, Indonesia post-New Order, Joko Widodo, human rights, oligarchy 


\section{Gabriela Morawska-Stanecka \\ Deputy Spealker of the Senate, Poland}

\section{Women Rights are Human Rights - why we Should Look Closely at the Situation in Asia?}

\section{Introduction}

Violence against women and girls is one of the most systematic and widespread human rights violations. Recent events in Poland, such as Constitutional Tribunal's ruling to restrict access to abortion, which is equal to complete ban on pregnancy termination, prove that the fight for women's rights is never over, regardless of geographical location and the level of prosperity of the country. In countries where there is a tendency to base the legal system on religious beliefs, it is women and children who always become the victims. If the anti-women policy continues in Poland and the relationship between right wing politicians and the Catholic Church becomes even stronger, one might wonder whether Poland will become a religious state in the future I am convinced that looking closer and analysing the situation of human rights in general and women rights in details in Asia can be an interesting starting point to discuss recent political changes in Eastern and Central Europe as well as an inspiration how to overcome difficulties in building society based on gender equality. It also proves that the topic of women's rights cannot be restricted to one country or region and should be treated as a global thread to human rights. 
Religion may be perceived as one of the main reasons why fundamental human rights of women and girls are violated, and that they are subjected to brutal violence. The influence of religious fundamentalists, including the religious fundamentalists, on the legal system can be even more threatening to equal rights in every state - the potential threats are for example recognised in Poland and described in the report by The Great Coalition for Equality and Choice titled "Cultural and Religious Counterrevolution. Is Polish Law under the Threat of Christian Fundamentalists' Ideology?"'.

In countries such as Pakistan Indonesia and Iran, where Islamic fundamentalism exists, we should not delude ourselves that this is the only cause of violence against women. Fundamentalism has many faces. The cases of Pakistan, Indonesia and Iran prove that fighting for human rights and women rights needs to involve education, social campaign and the support of the opinion leaders from around the world.

According to Pakistan Demographic and Health Survey 2017-2018 one in every five women in Pakistan is subjected to physical violence, a third of all married women experience it, as well. $28 \%$ of women aged 15 to 49 have experienced physical violence, $6 \%$ have experienced sexual violence since the age of $15.7 \%$ of women have experienced violence during pregnancy, 34\% of ever-married women have experienced spousal physical, sexual or emotional violence (NIPS 2019). According to the world rate of gender

1 The Federation for Women and Family Planning, Report "Cultural and Religious Counterrevolution - Is Polish Law Under the Threat of Christian Fundamentalists' Ideology?", Official website of the Federation for Women and Family Planning [access: 20.12.2020]. 
inequality in 2018, Pakistan is the sixth most dangerous country and the second worst performer in the world in terms of gender parity ${ }^{2}$.

According to the press reports, between January 2011 and July 201751241 cases of violence against women were officially reported to the police. These end in convictions only in $2.5 \%$ of the cases ${ }^{3}$. In "The Global Gender Gap Index 2018 Report" published by the World Economic Forum (WEF) on educational attainment, health and survival, political empowerment, Pakistan has been enlisted among the worst performers ${ }^{4}$ In Pakistan situations like the one, described in the interpellation to the European Commission concerning violation of the basic human rights of women in Pakistan, are very common, but the severity of the situation rarely reaches the general public One of the cases that was described in the news involved a 25-year - old Christian woman who was doused in acid before being set alight by a Muslim man, after she had refused to convert to Islam and marry him. Due to the severity of her wounds, she died in a hospital ${ }^{5}$. This case is just one example of how Christian girls are treated in Pakistan. Based on the EU's GSP+ assessment of Pakistan, the number of kidnappings, rapes and

2 World Economic Forum, The Global Gender Gap Report 2018, http://www3.weforum.org/docs/WEF_GGGR_2018.pdf [access: 20.12.2020].

3 Parliamentary questions, Official website of the European Parliament, https://www.europarl.europa.eu/doceo/document/E-9-2020001583_EN.html [access: 20.12.2020].

4 White Ribbon Pakistan, About Us, Official website of the White Ribbon Pakistan, https://www.whiteribbon.org.pk/about-us/ [access date: 10.12.2020].

5 Interpellations, Official website of the European Parliament, https://www.europarl.europa.eu/doceo/document/G-8-2018-000005_ EN.html [access: 10.12.2020]. 
forced conversions of mostly underage women and girls is estimated at around 1000 per year. Severe violence against Christian women ranges from murder to sexual violence, domestic violence, acid attacks, kidnapping and harassment ${ }^{6}$ The other well-known case is Asia Bibi's case ${ }^{7}$. Asia Bibi, a Christian farmworker, was sentenced to death for blasphemy in 2010. In October 2018 Pakistan's Supreme Court acquitted her of all charges and ordered her immediate release. In the face of pressure from parts of the public involving threats of violence and unrest, the government backtracked and agreed to stop Asia Bibi leaving the country until the Supreme Court heard a "review petition" in her case. She remained in protective custody, until January 2019, when the Supreme Court dismissed the review petition and upheld its acquittal ${ }^{8}$.

Pakistan's blasphemy laws are overbroad, vague and coercive, as the above described case proved. They have been used to target religious minorities, pursue personal vendettas and carry out vigilante violence. Although persecution of minorities applies to men and women alike, women do suffer more due to additional cultural constrains. On the basis of little or no evidence, the accused struggle to establish

6 European Commission Joint Staff Working Document, The EU Special Incentive Arrangement for Sustainable Development and Good Governance ('GSP+') assessment of Pakistan covering the period 2016 - 2017, https://trade.ec.europa.eu/doclib/html/156544.htm [access: 20.12.2020].

7 WorldWatch Monitor, The story of Asia Bibi, Official website of the WorldWatch Monitor, https://www.worldwatchmonitor.org/the-aasiya-noreen-story/ [access: 10.12.2020].

8 Amnesty International, Pakistan: Asia Bibi must finally get her freedom, Official website of the Amnesty International, https://www.amnesty.org/en/latest/news/2019/01/pakistan-asia-bibi-must-finally-gether-freedom/ [acess: 11.12.2020]. 
their innocence while angry and violent groups of people seek to intimidate the police, witnesses, prosecutors, lawyers and judges 9 .

To present another example. Indonesia is a country where Sharia law existing the Muslim - majority province Aceh. Islamic bylaw has been in force since the enactment of the province's Special Autonomy Law in 2001 and is enforced by religious courts. The law, in some cases, approves up to 200 lashes as punishment ${ }^{10}$. Punishable offences include same-sex relations, premarital sex and other sexual relations outside marriage, consumption of alcohol, gambling, being alone with someone of the opposite sex who is not a marriage partner or relative, committing sexual intimacy outside marriage, sexual abuse, rape, and accusing a person of adultery without providing four witnesses. Based on monitoring conducted by Amnesty International, there have been at least 120 individuals flogged in 2020. (There were 309 in 2019, and 235 in 2018) ${ }^{11}$.

The most common offences were consensual sexual relations outside marriage, being alone with someone of the opposite sex and gambling. Women and girls are often disproportionately affected by these laws, due to discrimi-

9 Library of Congress, Publications of the Law Library of Congress, Official website of the Library of Congress, https://www.loc.gov/law/ help/blasphemy/index.php\#Pakistan [access: 20.12.2020].

10 Amnesty International UK, Indonesia: Two women whipped 100 times for selling sex online, Official website of the Amnesty International UK, https://www.amnesty.org.uk/press-releases/indonesia-two-womenwhipped-100-times-selling-sex-online [access: 9.12.2020].

11 Amnesty International, Indonesia. Submission to the United Nations Committee on the Elimination of Discrimination Against Women. 78 ${ }^{\text {th }}$ Pre-Sessional Working Group, 13-17 July 2020, https://tbinternet. ohchr.org/treaties/cedaw/shared\%20documents/idn/int_cedaw_ico_idn_42444_e.docx [access: 20.12.2020]. 
natory gender stereotyped views of sexuality, for example, pregnancy outside marriage can be interpreted as proof that a woman has committed a crime ${ }^{12}$.

In order to illustrate the functioning of the Sharia law in Indonesia it is necessary to present a typical examples of public flogging. In East Aceh a young man was beaten unconscious as punishment for extramarital sex. After the punishment was completed, he required resuscitation and was taken to the hospital. In another incident in Aceh Tamiang, a woman was sentenced to 30 lashes - she fell unconscious when the punishment was carried out. Her punishment may be resumed at a later date, when she will be considered healthy enough to be beaten again ${ }^{13}$.

In addition, according to the National Commission on Violence against Women in Indonesia, supposed dress codes infractions are wrongly cited to excuse crime, because women victims are considered the responsible party in the sexual violence they experience. The Commission identified at least 21 regional regulations on dress codes which "directly discriminate against women"14.

In Aceh province, the Sharia police, and in some cases members of the public, conduct raids to ensure women comply to strict religious laws; non-compliance can lead to warnings or temporary detention. Dress codes can be

12 Amnesty International, Indonesia. Submission..., op.cit.

13 Amnesty International, Indonesia: Two people whipped unconscious in vicious public punishments, Official website of the Amnesty International, https://www.amnesty.org/en/latest/news/2019/12/indonesia-two-people-whipped-unconscious-in-vicious-public-punishments/ [access date: 7.12.2020].

14 Amnesty International, Indonesia. Briefing to the un Committee on the Elimination of Discrimination Against Women. $52^{\text {nd }}$ session July 2012, https://www2.ohchr.org/english/bodies/cedaw/docs/ngos/AmnestyInternationalForTheSession_Indonesia_CEDAW52.pdf [access: 20.12.2020]. 
a manifestation of underlying discriminatory attitudes and reflect a desire to control women's sexuality, objectifying women and denying their personal autonomy ${ }^{15}$.

Abortion is criminalized in most cases in Indonesia ()$^{16}$. A woman or a girl seeking an abortion, or a health worker providing one, may be sentenced to up to four or ten years of imprisonment. As a result of this law, abortions in Indonesia are often performed clandestinely in unsafe conditions. Under the 2009 Health Law, there are only two exceptions under Indonesian Law in which a woman may legally seek and health providers perform an abortion: if the health of the pregnant woman or the foetus is endangered or in the case of pregnancy resulting from rape. A woman who is pregnant as a result of rape, or a woman experiencing life-threatening complications as a result of pregnancy, has to meet several criteria to access abortion services, for example legal abortion provisions for rape victims are only permitted within the first six weeks of pregnancy. This limited timeframe means that most rape victims may not be able to access safe abortion within the required timeframe as they may not know they are pregnant yet ${ }^{17}$.

This situation is worsened in Indonesia's draft criminal code, which is currently being deliberated in parliament (2020). Under the draft criminal code, only doctors will

15 C. Broecker, Policing Morality. Abuses in the Application of Sharia in Aceh, Indonesia, Official website of the Human Rights Watch, https:// www.hrw.org/report/2010/11/30/policing-morality/abuses-application-sharia-aceh-indonesia\# [access: 20.12.2020].

16 Landiyanto, 2010.

17 Amnesty International, Indonesia Submission To The United Nations Committee On Economic, Social And Cultural Rights. 52 ${ }^{\text {nd }}$ Pre-sessional working group 2 to 6 December 2013, http://www.refworld.org/ pdfid/52d3c0624.pdf [access: 20.12.2020]. 
have the right to decide whether to perform an abortion based on health grounds. This contradicts the 2009 Health Law, according to which a woman can ask for an abortion in "a medical emergency." A woman who have had an abortion could be sentenced to up to four years in prison. Anyone who helps a pregnant woman get an abortion could be sentenced to up to five years in prison ${ }^{18}$.

The proposed law might lead also to prosecution of those selling or using emergency contraception with possible punishments of up to a six-month in jail. According to the Amnesty International research discriminatory practices in Indonesia and problematic laws prevent unmarried women and girls from accessing contraceptives ${ }^{19}$. Legal and political barriers introduced by the authorities, as well as the criminalization of sexuality, severely limit the freedom of women to make decisions about their sexuality. The access to certain methods of contraception or abortion requires the husband's permission, even in life-threatening situations. As reported by Amnesty International, healthcare workers often deny access to legal contraceptives for unmarried or childless women. The European Parliament adopted a resolution of 15 June 2017 on the human rights situation in Indonesia (2017/2724(RSP)), where it called on Indonesia's authorities to review all its laws and to ensure their conformity with the

18 Human Rights Watch, Indonesia: Draft Criminal Code Disastrous for Rights. Remove Provisions Harmful to Women, Minorities, Free Speech, Official website of the Human Rights Watch, https://www.hrw. org/news/2019/09/18/indonesia-draft-criminal-code-disastrous-rights [access: 20.12.2020].

19 Amnesty International, Indonesia: Barriers Preventing Women Achieving Reproductive Health, Official website of the Amnesty International, https://www.amnesty.org/en/press-releases/2010/11/19361/ [access: 12.12.2020]. 
country's international obligations, specifically those on freedom of expression, thought, conscience and religion, equality before the law, freedom from discrimination and the right to expression and public assembly ${ }^{20}$.

It is worth to mention also the case of Iran, where every year hundreds of Iranian women are killed as a result of honour killings. UN report says that almost $30 \%$ of all murders cases in Iran, are the honour murders of women and girls. According to World Economic Forum report, in 2017 Iran was the sixth - worst performer in the world in terms of gender parity.

23 - this is the number of limitations in the Iranian legal system concerning married women: applying for a passport, travelling outside their homes, choosing of the place of residency and many other, very usual for us, aspects of everyday life - women cannot find work and can't work like men. Discrimination based on gender is a reality. The Iranian civil code provides that a man can prevent his wife from working, if he deems that it's against the interest of the family or his dignity. Women don't have legal protection against domestic violence or sexual harassment. In the Iranian legal system you won't find non-discrimination provisions ${ }^{21}$. According to an Amnesty International report, the respect for human rights has got seriously worse ${ }^{22}$.

20 European Parliament resolution of 15 June 2017 on the human rights situation in Indonesia, Official website of the European Parliament, https://www.europarl.europa.eu/doceo/document/TA-8-2017-0269_ PL.html [access: 12.12.2020].

21 More on this topic can be found in Georgetown Institute for Women, Peace and Security and Peace Research Institute Oslo. 2017. Women, Peace and Security Index 2017/18: Tracking Sustainable Peace through Inclusion, Justice, and Security for Women. Washington, DC: GIWPS and PRIO.

22 Country Reports on Human Rights Practices for 2019 United 
The Norway-based Iran Human Rights (IHR) organization is warning that in Iran 9 - year-old girls and 15-yearold boys can be executed ${ }^{23}$.

At least 73 juvenile delinquents were executed in 20052015. The authorities show no intention of stopping these violent practices ${ }^{24}$.

In 2019 UN criticized the human rights situation in Iran and suggested a necessity of improving it especially in the area of the women rights. However, it is important to realise that in in comparison with South Asia regions, women in Iran still have better access to the bank accounts, education and mobile phones.

\section{Conclusions}

Why should we look closely at the situation of women in Asia? The $21^{\text {st }}$ century has proven that women leaders are capable of governing countries better than men in situations of crisis like the current pandemic, as is the case in New Zealand, Finland or Germany. But at the same time in majority of countries women are denied not only a fair participation in government, but basic human rights. The

States Department of State - Bureau of Democracy, Human Rights and Labor, Iran 2019 Human Rights Report, https://www.state.gov/wp-content/uploads/2020/03/IRAN-2019-HUMAN-RIGHTS-REPORT.pdf [access: 12.12.2020].

23 M. Rafizadeh, Iran: Child Executions, Amputations, Floggings, Official website of the Gatestone Institute International Policy Council, https://www.gatestoneinstitute.org/13841/iran-executions-amputationsfloggings [access: 12.12.2020].

24 Amnesty International UK, DEATH PENALTY. Iran is sentencing children and teenagers to death, Official website of the Amnesty International UK, https://www.amnesty.org.uk/iran-juvenile-offenders-death-row-execution [access: 12.12.2020]. 
analysis of the situation of women in Asia allows not only to understand the political, religious and cultural constrains faced by women, but also provide suitable help for those in need. It needs to be said that this help is still, sadly, symbolic and more efforts should be made to cooperate and support local organizations - they know best how to make the fight for women rights efficient and adequate, they are also able to cooperate with local authorities and leaders to make even small, but significant, changes. Our obligation and responsibility as politicians is to step up and fight for women's rights everywhere and see this problem as an international and global issue not only because gender equality is one of the cornerstones of our civilization, but because when women's rights are violated, it is the whole world that loses out.

\section{Bibliography}

Amnesty International UK, DEATH PENALTY. Iran is sentencing children and teenagers to death, Official website of the Amnesty International UK, https://www.amnesty. org.uk/iran-juvenile-offenders-death-row-execution. Amnesty International UK, Indonesia: Two women whipped 100 times for selling sex online, Official website of the Amnesty International UK, https://www.amnesty.org. $\mathrm{uk} /$ press-releases/indonesia-two-women-whipped100-times-selling-sex-online.

Amnesty International, Indonesia: Two people whipped unconscious in vicious public punishments, Official website of the Amnesty International, https://www.amnesty.org/ en/latest/news/2019/12/indonesia-two-people-whippedunconscious-in-vicious-public-punishments/. 
Amnesty International, Pakistan: Asia Bibi must finally get her freedom, Official website of the Amnesty International, https://www.amnesty.org/en/latest/news/2019/01/ pakistan-asia-bibi-must-finally-get-her-freedom/.

Country Reports on Human Rights Practices for 2019 United States Department of State Bureau of Democracy, Human Rights and Labor, Iran 2019 Human Rights Report, https://www.state.gov/wp-content/uploads/2020/03/ IRAN-2019-HUMAN-RIGHTS-REPORT.pdf.

European Parliament resolution of 15 June 2017 on the human rights situation in Indonesia, Official website of the European Parliament, https://www.europarl.europa.eu/ doceo/document/TA-8-2017-0269_PL.html.

Interpellations, Official website of the European Parliament, https://www.europarl.europa.eu/doceo/document/G-8-2018-000005_EN.html.

Landiyanto, Erlangga Agustino, Abortion Policy in Indonesia: Rights, Law and Religious Perspectives (April 2, 2010), https://ssrn.com/abstract=1583403 or http:// dx.doi.org/10.2139/ssrn.1583403.

National Institute of Population Studies (NIPS) [Pakistan] and ICF. 2019. Pakistan Demographic and Health Survey 2017-18. Islamabad, Pakistan, and Rockville, Maryland, USA: NIPS and ICF.

Parliamentary questions, Official website of the European Parliament, https://www.europarl.europa.eu/doceo/ document/E-9-2020-001583_EN.html.

Rafizadeh R., Iran: Child Executions, Amputations, Floggings, Official website of the Gatestone Institute International Policy Council, https://www.gatestoneinstitute. org/13841/iran-executions-amputations-floggings. 
White Ribbon Pakistan, About Us, Official website of the White Ribbon Pakistan, https://www.whiteribbon.org. $\mathrm{pk} /$ about-us/.

WorldWatch Monitor, The story of Asia Bibi, Official website of the WorldWatch Monitor, https://www.worldwatchmonitor.org/the-aasiya-noreen-story/.

\begin{abstract}
This paper provides data on human rights and women rights violation in Pakistan, Indonesia and Iran. It concentrates on issues such as reproductive rights and gender equality, but also other aspects such as minority rights, where women and children from minorities suffer disproportionally more. The author concludes, that more efforts should be put in working with local women rights advocates and that the problems raised by women are neither gender nor region restricted. They are global and that's the reason why general public and decision makers should look closely at Asia and the women struggle there gives researchers and politicians a perspective needed to truly understand the challenges faced by women everywhere.
\end{abstract}

Keywords: women rights in Asia, abortion, gender equality, women rights in Pakistan, women rights in Indonesia, women rights in Iran 


\section{Ghias Aljundi}

Consultancy الجندي غياث Independent Human Rights Consultancy on Middle East \& North Africa

\section{The Arab Spring. The Syrian Autumn}

\section{Introduction $^{1}$}

A decade ago, dramatic social unrest took place in Tunisia after a policewoman slapped a young man selling fruits on his cart. Mohammed Bouazizi set himself on fire outside the municipal headquarters in the town of Sidi Bouzid. Protests spread throughout Tunisia demanding first the improvement of the economic situation and then political change.

After Tunisia, protests moved quickly across the police states of the region. First in Egypt and then to Libya, Bahrain, Yemen and Syria. The story of Bouazizi became the story of every single citizen in these states and others.

People went to the streets demanding social justice, freedoms, dignity and an end to corruption. They simply wanted political change. People across the region had been suffering drastic human rights violations including arbitrary arrest and torture for merely criticising regimes or showing dissatisfaction towards the political and economic situation.

Amazing and promising mass protests with real opportunity seemed the change was no longer out of reach. Taking part in the process, no matter how difficult, or bloody, appeared to be possible after all.

1 This article depends on internet sources and direct observation as a human rights expert. 
For the first time in decades, hope was possible to attain and change was around the corner. The outcome of mass protests varied from one country to another. In Tunisia, the dictator fled the country only after 20 days of protest, the Egyptian resigned after 18 days $^{2}$ and the army formed a Military Council which was a continuity of the old regime. While in Yemen and Bahrain, the Saudi Arabian influence was very direct. The Saudis sent their tanks to Bahrain and in Yemen, they brokered an "agreement" by which the dictator handed his power to his deputy before he went back to fight for power.

Observers, experts, politicians and even many citizens were highly surprised that the mass protests reached Syria because Syria was completely built on intimidating, suppressing and oppressing people. Since 1970, the Syrian regime built multi security apparatuses ${ }^{3}$ to completely spread fear among citizens. Prolonged arbitrary arrest, severe torture and disappearance for the regime's critics. Peaceful activists spent up to twenty years in prisons without trial or charge. Because of this, Syria was/is called the Kingdom of Fear.

\section{The Spark}

In early March 2011, the Syria regime's security forces arrested 15 pupils in the town of Daraa aged between 10 and 15 after they wrote on their school's walls "people want to bring

2 Major events in Egypt since the Arab Spring uprisings, Reuters Staff, https://www.reuters.com/article/egypt-uprising-anniversaryidUSL8N2JT1FE [access: 15.02.2021].

3 The Syria Justice and Accountability Centre (SJAC), p. 14, https:// syriaaccountability.org/wp-content/uploads/Walls-Have-Ears-English. pdf [access: 15.02.2021]. 
down the regime", after being influenced by the slogans of the Egyptian and Tunisian revolutions. These young boys were tortured, electrocuted and had their fingernails pulled out, leading to unprecedented unrest on 15 March $2011^{4}$.

On 18 March 2011, security forces opened fire on protesters, killing four and injuring dozens. Days later, between 23 March 2011 and 25 $5^{\text {th }}$, Daraa's Al-Omari Mosque which protesters took refuge in, was raided by the security forces killing more than 30 protesters ${ }^{5}$.

The events of Daraa spread into other cities and towns and the regime's security forces continued to fire and kill protesters.

\section{Peaceful protests}

The peaceful protests covered most Syrian cities and towns including parts of Damascus and Aleppo in addition to the vast majority of the countryside. As the protests intensified, so did the attacks on protesters. The peaceful period lasted until July 2011 when arms started appearing in different areas of Syria.

Assad's regime pushed to the maximum to stop the protests with the massive crackdown on protesters and at the time using censorship and arresting social media activists. He stifled the country and thousands of people were ar-

4 J. Tarabay, For many Syrians, the story of the war began with graffiti in Dara'a, CNN, https://edition.cnn.com/2018/03/15/middleeast/daraasyria-seven-years-on-intl/index.html [access: 16.02.2021].

5 Crimes against Humanity by Syrian Security Forces, Human Rights Watch, https://www.hrw.org/report/2011/06/01/weve-neverseen-such-horror/crimes-against-humanity-syrian-security-forces [access: 16.02.2021]. 
rested in order to spread the fear. By the end of April, it became clear that there was no return and the situation was going out of control. As the crackdown continued, the peaceful protests also continued. On 18 April 2011, tanks of the Syrian regime attacked a peaceful sit-in named The Clock Sit-In in Homs city. Hundreds of peaceful protesters were killed. Many protesters ran for safety in the buildings around the square but the security forces surrounded them and the majority were arrested; many have never come back or been heard from since. It's highly believed that this was a turning point in the events taking place in Syria ${ }^{6}$.

\section{Armed conflict}

As the situation began to go out of control, armed opposition movements with mainly defectors from the regime's army started gradually emerging and the peaceful protests were marked with some armed rebellion. Peaceful protests lasted until the end of July 2011 when a group of army officer defectors formed what was called the Free Syrian Army. This marked the end of the peaceful uprising.

As the regime was unable to put an end to the peaceful protests, its army launched military assaults on different areas in Syria. The army attacked Dara'a in April 2011, Tal Kalakh (a suburb of Homs) on May 2011, Baniyas (a suburb of Tartous) and Lattakia in May and August 2011. More peaceful protests took place in Dara'a and other cities after the attacks. In Hama, at the beginning of July 2011, hundreds

6 Syria: Rising Toll in Homs, Human Rights Watch, https://www. hrw.org/news/2011/07/02/syria-rising-toll-homs [access: 17.02.2021]. Ten Years On the Homs Clock Tower Massacre, the Syrian Human Rights Committee, https://www.shrc.org/en/?p=33831 [access: 19.02.2021]. 
of thousands of protesters went to the streets demanding political change and chanting to bring down the regime ${ }^{7}$.

\section{Attacks on civilians}

After July 2011, the regime intensified its assaults on different cities in Syria and the regime's forces started bombing towns and villages indiscriminately; civilians were the main victims. Since 2015, the year of the Russian intervention, the regime and the Russian warplanes indiscriminately attacked civilians in different areas of Syria. The regime used barrel bombs which are a tool of mass killing because, unlike rockets, the barrels dropped from helicopters cannot be directed or controlled. According to witnesses and activists, barrel bombs were only dropped on residential areas. In 2018, reports stated that more than 1600 civilians were killed between February and March. Reports also mentioned that in that period "25 medical facilities, 11 schools" ${ }^{8}$ were destroyed.

The Assad regime used internationally banned chemical weapons in different areas of Syria. On April 4, 2017, the regime's warplanes attacked Khan Sheikhoun town in the north-western of Idlib province with a nerve agent, killing at least 90 people, 30 of them children. The deadliest chemical attack was carried out on Eastern Ghouta, next to Damascus, in August 2013. According to witnesses more than 1500 civilians were killed, including hundreds of children?

7 Syria: 'Hundreds of thousands' join anti-Assad protests, BBC, https://www.bbc.co.uk/news/world-middle-east-13988701 [access: 19.02.2021].

8 Syria: Events of 2018, https://www.hrw.org/world-report/2019/ country-chapters/syria [access: 19.02.2021].

9 Death by Chemical, https://www.hrw.org/report/2017/05/01/ 
On the other hand, armed opposition groups also targeted civilians in different areas though this cannot be compared to the regime's attacks. They were also accused of having arms and armed men in residential areas.

\section{Foreign Intervention}

The foreign involvement in Syria took two forms, political and military. Parties involved in the war in Syria receive various types of support from foreign countries and entities based outside Syria. The regime had early support from regional players such as Hezbollah and Iran. While Russia started supporting Assad politically in the early stages and defended him in the UN Security Council by, alongside China, using vetoes to halt any possible actions by the UN or other countries, Russia formally sent its army to Syria in 2015 and since then it has been taking a leading role in mostly air bombardment especially in the north of Syria. Dozens of schools, hospitals and other infrastructure have been destroyed ${ }^{10}$.

Iran and Hezbollah brought into Syria mercenary militias from different countries such as Pakistan, Afghanistan, Iran and others. They have been fighting mostly under the control of Iran.

Hezbollah militias had an early involvement shortly after the breakout of peaceful protests in March 2011. There are several reports that the militias were used to attack protesters on the streets. According to the Lebanese Daily Star

\footnotetext{
death-chemicals/syrian-governments-widespread-and-systematic-use-chemical-weapons [access: 15.02.2021].

10 Syrian and Russian Strikes on Civilian Infrastructure, Human Rights Watch, https://www.hrw.org/report/2020/10/15/targeting-life-idlib/ syrian-and-russian-strikes-civilian-infrastructure [access: 21.02.2021].
} 
newspaper, Nasrallah said that Hezbollah fighters helped the Syrian government "retain control of some 23 strategically located villages [in Syria] inhabited by Shiites of Lebanese citizenship"11.

"Hezbollah was involved in the Siege of Homs (2011-14), the Battle of Zabadani (2012), the Battle of al-Qusayr (2012) and the Battle of Aleppo (2011-16)"12. The darkest side of Hezbollah's involvement in Syria was the idea of changing the movement into a Sunni-Shi'a war. This involvement was seen by the vast majority of Syrians as a Shi'a group coming to Syria to attack Sunnis. This pushed the movement fast towards armed conflict.

On the other hand, armed groups enjoyed substantial financial and military support from regional powers such as Qatar, Saudi Arabia and Turkey. These groups are mainly jihadist groups who controlled different parts of Syria and currently they are mostly based in the north after the regime restored many captured parts.

The Kurdish areas known as Rojava have been controlled by the Syrian Democratic Forces and these forces have mainly been receiving support from the US. In many cases, there have been proxy wars inside Syria, mainly between Sunni Saudi Arabia and Shia'a Iran and on other hand between Russia and the West. There is also a war between the Kurdish forces and the National Syrian Army created by Turkey mostly to capture Kurdish areas on behalf of Turkey.

11 D. Hirst, Hezbollah uses its military power in a contradictory manner, http://www.dailystar.com.lb/Opinion/Commentary/2012/ Oct-23/192380-hezbollah-uses-its-military-power-in-a-contradictorymanner.ashx\#axzz2AJrVn2Ik [access: 15.02.2021].

12 See more: Foreign involvement in the Syrian civil war, https:// en.wikipedia.org/wiki/Foreign_involvement_in_the_Syrian_civil_ war\#Hezbollah [access: $15.02 .202 \overline{1}$ ]. 


\section{Journalists and human rights defenders}

The Syrian regime has a history of targeting, journalists and freedom of expression since the early days of its rule. The Syrian constitution guarantees freedom of speech but in practice freedom of expression is heavily restricted and the regime imposes strict censorship on all kinds of freedom of expression. There is no independent media. Torture, disappearance and death are the possible fate of those who exceed the little-tolerated margin of freedom of expression. There is a complete lack of access of information. "The government has long operated with minimal transparency and public accountability"13.

Since the start of the events in 2011, journalists and human rights defenders and those who advocated for freedom of expression have faced dark fate at the hands of the Syrian security forces who enjoyed full impunity. Also, armed groups have targeted journalists and activists ${ }^{14}$. Hundreds of journalists and citizen journalists have been killed or disappeared. Journalists have been playing a vital role to document crimes committed by the Assad regime throughout Syria ${ }^{15}$. This has made them easy targets for the brutal security forces and also for the regime's supporters known as Shabiha ${ }^{16}$.

13 Syria: Freedom House, https://www.justice.gov/eoir/page/ file/1186516/download [access: 16.02.2021].

14 Syria: Fears for Life of Free Expression Advocate, https://www.hrw. org/news/2015/11/20/syria-fears-life-free-expression-advocate [access: 15.02.2021].

15 B. Karacaoglu, A. Karaahmet, Journalists expose Assad regime at cost of their lives, https://www.aa.com.tr/en/middle-east/journalists-expose-assad-regime-at-cost-of-their-lives/2105180 [access: 15.02.2021].

16 Armed civilian supporters of Assad who were used by the regime to terrorise and intimidate any opponents or critics of the regime with full 
The Assad regime also targeted foreign journalists covering the Syrian events. In February 2012, the regime's forces targeted foreign journalists including Marie Colvin and Rémi Ochlik in Bab Amr, Homs. The two journalists were immediately killed, and dozens of other journalists were injured ${ }^{17}$. Many others were kidnapped and disappeared in the regime's jails.

In the north of Syria where Islamist armed groups control the province of Idlib and some of Aleppo's countryside, journalists face continuous intimidation, arrest and even assassination. In November 2020, Fathaia ${ }^{18}$ and another colleague were arrested for a week because they wrote about the internally displaced people (IDP) situation in the camps. The two women were detained in harsh prison conditions and were threatened with sexual attacks. They were released after one week after some elderly people intervened with the armed group Hayat Tahrir Sham (HTS). Similar to the regime's practices, the HTS forced the two female journalists to sign an undertaking that they would not write about similar issues. After their release, the journalists fled the whole area as harassment and threats against them continued.

Other journalists also were arrested in different areas of Idlib province for different reasons. Raed Fares was a Syrian journalist, activist and civil society leader from Kafr Nabl, Idlib, Syria. He was the founder of Radio Fresh FM in 2013, an independent radio station reaching audiences in Idlib,

range of immunity and support from the secret services, https://en.wikipedia.org/wiki/Shabiha [access: 15.02.2021].

17 J. Dwyer, R. Gallagher, The Intercept - How the Assad Regime Tracked and Killed Marie Colvin for Reporting on War Crimes in Syria, https://theintercept.com/2018/04/09/marie-colvin-syria-assad/ [access: 17.02.2021].

18 A pseudonym for a journalist operating in the area. This is from a direct interview with her on 19 February 2021. 
Aleppo and Hama. He was killed by what was widely believed to be Hayat Tahrir Sham in late November 2018 together with another journalist and activist, Hamoud Jneed. The killing of the journalists came after several assassination attempts by the same group ${ }^{19}$.

The National Syrian Army, militias created and supported by Turkey, which operates in the Kurdish area of Afrin, widely targeted journalists and human rights defenders. Dozens of Kurdish journalists and defenders were forced to flee the area. Many also were arrested. According to the Violation Documentation Centre, two journalists were arrested in 2019 by these militias.

\section{Artists}

From the start of the events in March 2011, the Syrian regime promoted propaganda that "the government was fighting terrorists". Contrary to its propaganda, Assad arrested dozens of artists, actors, actresses and writers. Many died in custody ${ }^{20}$ and many fled the country. Adnan Zirae, an actor and script writer was kidnapped by the regime's secret services in February 2012 and his family have never heard from him since. A death certificate was issued by the regime that he "died of a heart attack". This is a description the regime used for those who died in its custody ${ }^{21}$. Zaki Kordillo, a movie, theatre and TV actor from Aleppo, was arbitrarily

19 Raed Fares, https://en.wikipedia.org/wiki/Raed_Fares_(activist) [access: 16.02.2021].

20 Syria: Human slaughterhouse: mass hangings and extermination at Saydnaya prison, Syria, https://www.amnesty.org/en/documents/ mde24/5415/2017/en/ [access: 15.02.2021].

21 A conversation with his relatives on 22 February 2021, a private archive of the author. 
arrested along with his son Mehyar in August 2012. He and his son have never been heard from since. Actress Samar Kokash was sentenced for five years in 2013 as a result to her humanitarian activities ${ }^{22}$.

Dozens of other artists, actors and actresses were detained and later had to flee the country. The regime used its media machines to spread rumours that these "artists supported terrorism”. One well-known actor, Jalal Al-Tawil, was arrested and then forced to appear on the regime's TV to "admit" his connections to armed groups. Al-Tawil fled Syria after his release and he spoke of the horror he was subjected to inside the secret services branches ${ }^{23}$.

\section{Caesar's pictures and the disappeared}

In January 2014, a Syrian military photographer defected and smuggled shocking evidence of torture out of Assad's deadly slaughtering jails. Around 55000 pictures of dead bodies who were killed under torture and turned into numbers in Assad's jails ${ }^{24}$.

Between 2011 and 2013, the former Syrian military photographer who called himself Caesar to stay anonymous used a police computer in Damascus to copy thousands of photographs of detainees who were tortured to death in Assad's jails ${ }^{25}$.

22 Syrian artists standing against tyranny, Freemuse, https://freemuse. org/news/syrian-artists-standing-against-tyranny-2/ [access: 19.02.2021].

23 Ibidem.

24 Syria: Stories Behind Photos of Killed Detainees, Human Rights Watch, https://www.hrw.org/news/2015/12/16/syria-stories-behind-photos-killed-detainees [access: 21.02.2021].

25 Ibidem. 
Caesar took photographs of tortured, starved and burnt bodies. His tasks were merely to photograph the bodies in order to document prisoners' deaths. The shocking terrifying images showed evidence of systematic killing of Syrians. International senior war crimes prosecutors spoke about evidences of "war crimes"26.

Torture had been a systematic tool used by Assad the father against his opponents in his brutal detention centres ever since he took over in 1970 . However, the number of people who died under torture before 2011 was dramatically smaller than after the events of 2011 . Torture has been the essential instrument used by both Assads to stifle their opponents. Since 2011, the brutality of the regime's secret services has become uncontrollable and the perpetrators have enjoyed a full range of impunity ${ }^{27}$.

Amnesty International described one of Assad's brutal prisons, Saydnaya, as a "slaughter house ${ }^{28}$ ". "At Saydnaya Military Prison, the Syrian authorities have quietly and methodically organized the killing of thousands of people in their custody. Amnesty International's research shows that the murder, torture, enforced disappearance and extermination carried out at Saydnaya since 2011 have been per-

26 I. Black, Syrian regime document trove shows evidence of 'industrial scale' killing of detainees, https://www.theguardian.com/world/2014/jan/20/ evidence-industrial-scale-killing-syria-war-crimes [access: 22.02.2021].

27 End the horror in Syria's torture prisons, Amnesty International, https://www.amnesty.org/en/latest/campaigns/2016/08/syria-torture-prisons/ [access: 15.02.2021]; B. Karacaoglu, A. Karaahmet, E. Emre Ozcan, Syrian woman tells of torture she suffered in regime prisons, https://www.aa.com.tr/en/middle-east/syrian-woman-tells-of-tortureshe-suffered-in-regime-prisons/2291206 [access: 23.02.2021].

28 Syria: Human slaughterhouse: mass hangings and extermination at Saydnaya prison... 
petrated as part of an attack against the civilian population that has been widespread, as well as systematic, and carried out in furtherance of state policy. ${ }^{29}$ "

According to several witnesses who experienced the hell of Assad's brutal treatment, what is hidden inside Assad's jails and detention centres is far worse than we have so far unearthed. Torturing civilians to death was used as a horror example to deter other Syrians from taking any actions or participate in protests against the regime.

There has been no single case where the regime handed bodies of the killed people to their families. Many families knew about their loved ones' fate from records when they extracted a document called in Syria "Family Record". Some families found the word "died" next to their loved ones' names. Mostly there was a standard sentence next to the names: "died of heart attack". The regime's authorities refuse to issue a death certificate and as we mentioned refuse to hand the bodies to the families ${ }^{30}$.

According to the Syrian Network for Human Rights $(\mathrm{SNHR})^{31}$, working on documenting disappearance, around 100000 Syrians have been disappeared since $2011^{32}$.

29 See previous, https://www.amnesty.org/en/documents/mde24/54 15/2017/en/ [access: 22.02.2021].

30 Syria: Families left alone to find answers about disappeared relatives, https://www.amnesty.org/en/latest/news/2019/08/syria-families-left-alone-to-find-answers-about-disappeared-relatives/ [access: 15.02.2021].

31 At lease 167 cases of arbitrary arrest/detention documented in Syria in November 2020, Syrian Network for Human Rights, https:// sn4hr.org/wp-content/pdf/english/At_least_167_cases_of_arbitrary_arrests_in_Syria_in_November_2020_en.pdf [access: 18.02.2021].

32 F.A. Ghany, The tale of enforced disappearances in Syria, https:// voelkerrechtsblog.org/99000-disappeared-and-counting/ [access: 19.02.2021]. 
In an extraordinary unique action, two Syrian former secret services officers have been on trial in Germany for crimes against humanity. This is part of the Universal Jurisdiction ${ }^{33}$. "Judges in the city of Koblenz will begin hearing evidence on April 23, 2020 in the first trial about torture by state agents during Syria's nearly decade-long brutal armed conflict., ${ }^{34}$

Another Syrian doctor and former officer in the regime's army, Alaa Mousa, was arrested in June 2020 in the state of Hesse on suspicion of crimes against humanity in Syria while serving in the regime's army ${ }^{35}$ Some of his victims recognised him when they saw him in a hospital in Germany where he was working. According to witnesses, he burnt detainees' genitals and tortured some detainees to death. "The suspect is accused of having "tortured a detainee... in at least two cases" at a prison run by the Syrian intelligence service in the city of Homs in 2011, according to German federal prosecutors ${ }^{36}$."

Although these are good examples of justice for victims, the vast majority of perpetrators in Syria, including Assad and his family, are still enjoying impunity while the victims' families are living in total agony.

33 Germany: Syria Torture Trial Opens, https://www.hrw.org/news/ 2020/04/23/germany-syria-torture-trial-opens [access: 19.02.2021].

34 German police arrest Syrian doctor for 'crimes against humanity', https://www.dw.com/en/german-police-arrest-syrian-doctor-for-crimesagainst-humanity/a-53895002 [access: 19.02.2021].

35 Ibidem.

36 Syrian doctor arrested in Germany for alleged crimes against humanity, https://www.theguardian.com/world/2020/jun/22/syrian-doctor-arrested-germany-alleged-crimes-against-humanity [access: 19.02.2021]. 


\section{Women}

Women have been big victims in the Syrian conflict. Women have suffered attacks from all sides of the war. The Syrian regime arrested and killed many women and, according to many witnesses and victims' statements, the regime's forces and supporters harassed women and sexually abused them. Caesar's pictures showed many women killed under torture.

Women also had to take extra responsibilities when their husbands were disappeared or killed either by the air bombardments or inside Assad's jails. They fled with their children to safety and had to find ways to feed them. "In many cases, they have become the sole breadwinners overnight, after losing husbands and fathers to the conflict" ${ }^{37}$.

Women, including women human rights defenders and journalists suffered violence and physical attacks. Also, according to a report published by the Euro-Mediterranean Human Rights Network, women have described their suffering during the years of conflict. "Syrian human rights groups have reported the use of civilians, including women and children as human shields in several locations in Syria during incursions into neighbourhoods where government forces encountered fierce resistance, or for the purpose of escaping fire and clashes." ${ }^{38}$

On the other side, Islamist armed groups imposed drastic restrictions on women. In the north and the east of Syria,

37 Syrian Women, https://www.icrc.org/en/where-we-work/middle-east/syria/syrian-women [access: 22.02.2021].

38 S. Nasar, Violence against Women, Bleeding Wound in the Syrian Conflict, https://euromedrights.org/wp-content/uploads/2015/03/Docreport-VAW-Syria1.pdf [access: 22.02.2021]. 
women were forced to wear niqabs and their movements were restricted. Many women were brutally lashed and beaten for breaking "the Islamic rules".

On the way to exile, women suffered sexual abuse during their journeys either by smugglers or by their journey companions.

Women were "Easily exploited by locals, police officers, or security guards along their journeys, many refugee women feel pressured to trade sexual favors to smugglers in exchange for aid or cheaper passage to safety, or they form relationships on the road so that they could have a man to take care of their families"39.

\section{Refugees and Internally displaced people}

Since March 2011, at least half of Syria's population either have fled the country or have been internally displaced. According to the UNHCR "Over 5.6 million people have fled Syria since 2011, seeking safety in Lebanon, Turkey, Jordan and beyond." ${ }^{40}$ These are the ones who have been registered. There are hundreds of thousands who have not been registered and they are living in neighbouring countries. Inside Syria, more than 5 million Syrians were internally displaced mainly from Aleppo, Idlib, Homs and other areas under attacks.

While around a million of Syrians were lucky to reach Europe during the 2015 refugee movement across the Mediterranean after long, expensive and risky journeys during

39 Y. Asaf, Syrian Women and the Refugee Crisis, https://www.mdpi. com/2076-0760/6/3/110 [access: 22.02.2021].

40 Syria emergency, https://www.unhcr.org/syria-emergency.html [access: 22.02.2021]. 
which many lost their lives in the water, millions stayed in neighbouring countries such as Turkey, Jordan and Lebanon. In Jordan, most Syrian refugees live in Zaatari refugee camp with harsh conditions and restriction of movement ${ }^{41}$.

The worst situation for Syrian refugees may be in Lebanon according to reports. Attacks and abuse of refugees are common in Lebanon and politicians usually blame Lebanon's crisis on Syrian refugees. Racial abuses were clearly mentioned on TVs, newspapers and social media. Also, attacks on the camps have happened frequently. In December 2010, several Lebanese men set fire to a Syrian refugee camp in the north of Lebanon which left dozens of families without any shelter or support ${ }^{42}$.

Turkey hosts more than 4 million Syrians. Although they are living more comfortably than in Lebanon, the Turkish authorities do not recognise Syrians as refugees. They are considered "guests" which leaves them without rights. Also, there are strict restrictions on the movement of Syrian refugees within Turkey. As a refugee, you cannot leave your town to go to another town without a permit from the mayor. This is usually difficult to obtain. Also, during 2019/2020, Turkey randomly deported thousands of Syrians back to the north of Syria where its allies, the Islamist armed groups, rule. The area is not safe as it's constantly bombarded by the Syrian and Russian warplanes in addition to the severe oppression by the Islamist groups ${ }^{43}$. Also Turkey caused in-

41 Zaatari Refugee Camp - Factsheet, May 2020, https://reliefweb.int/report/jordan/zaatari-refugee-camp-factsheet-may-2020 [access: 24.02.2021].

42 Syrian refugees flee Lebanon camp after tents set on fire, https:// www.theguardian.com/world/2020/dec/27/syrians-refugees-flee-lebanon-camp-after-tents-set-on-fire [access: 24.02.2021].

43 Turkey: Nearly 100,000 unregistered Syrians removed from Is- 
ternal displacement of thousands of the Kurdish population after its invasion of the Kurdish areas of Syria in 2018 and establishment of extremist militias.

The Assad regime, Iran and Russia had been accused of preventing refugees, especially in Lebanon and Jordan, from returning to specific areas in Syria where fighting in their areas stopped. Many of those who were deported from Lebanon or succeeded to return were arrested or harassed by the regime's forces ${ }^{44}$. In recent days, Assad and his secret services threatened to confiscate properties in Syria of refugees who had fled the country.

\section{Conclusions}

On 15 March 2021, it's the tenth anniversary of the Syrian revolution/war. After ten years of oppression, fighting and bombardment, existence in Syria as it was before 2011 has disappeared. The vast majority of the infrastructure has been destroyed or is dysfunctional. As the country is on its knees, the oppressive regime continues with its oppressive policies while at least four armies are intervening in the country ${ }^{45}$.

tanbul, https://www.dw.com/en/turkey-nearly-100000-unregistered-syrians-removed-from-istanbul/a-51888092 [access: 22.02.2021]; Turkey: Syrians Being Deported to Danger, https://www.hrw.org/news/2019/10/24/ turkey-syrians-being-deported-danger [access: 22.02.2021].

44 Syrians Deported by Lebanon Arrested at Home, https://www. hrw.org/news/2019/09/02/syrians-deported-lebanon-arrested-home [access: 26.02.2021]; B. Hubbard, Syria Seeks Return of Refugees, but They Fear Leader's Wrath, "New York Times", https://www.nytimes. com/2020/11/12/world/middleeast/12syria-refugees-assad.html [access: 26.02.2021]; A. Vohra, Deadly, Welcome Awaits Syria's Returning Refugees, https://foreignpolicy.com/2019/02/06/a-deadly-welcome-awaits-syrias-returning-refugees/ [access: 26.02.2021].

45 S. Lucas and others, Syria: Who's involved, and what do 
The economic situation is dire and Syrians find it extremely difficult to survive and to secure the minimum standard of living. Corruption has reached uncontrollable levels and those who criticise corruption, even among the regime's supporters, face detention and torture. The Syrian Lira has fallen from 50 for 1 USD in 2011 to 3500 Liras for 1 USD in 2021. Freedom of expression and media are also dire. Detention of activists and journalists continues without any legal basis $^{46}$.

Assad is planning to re-run in the June 2021 so-called elections for another term in office, He definitely will not have a rival and the elections will definitely not be transparent. People will be forced to vote for Assad or face consequences as has been the usual practice since 1970.

All attempts to find a solution for the Syrian tragedy have been failed by the regime depending on the unlimited support of the Russians in the UN or other international bodies. The recent "negotiations" between the regime and opposition in Geneva to write a new Syrian Constitution have failed and the UN envoy accused the regime of failing the negotiations ${ }^{47}$. The hope for finding a political solution by implementing the UN resolution 2254 does not exist and as a result, only Syrian people continue to suffer.

they want?, https://theconversation.com/syria-whos-involved-and-whatdo-they-want-95002 [access: 23.02.2021].

46 Syria report 2020, Freedom House, https://freedomhouse.org/ country/syria/freedom-world/2021 [access: 25.02.2021].

47 S. Nebehay, UN Syria envoy says constitutional talks in peril, https://www.reuters.com/article/us-syria-un-idUSKBN29Y2G1 [access: 26.02.2021]. 


\section{Bibliography}

Armed civilian supporters of Assad who were used by the regime to terrorise and intimidate any opponents or critics of the regime with full range of immunity and support from the secret services, accessed on 15 February 2021, https://en.wikipedia.org/wiki/Shabiha.

At lease 167 cases of arbitrary arrest/detention documented in Syria in November 2020, Syrian Network for Human Rights, accessed on 18 February 2021, https://sn4hr.org/ wp-content/pdf/english/At_least_167_cases_of_arbitrary_arrests_in_Syria_in_November_2020_en.pdf.

Black I., Syrian regime document trove shows evidence of 'industrial scale' killing of detainees, accessed on 18 February 2021, https://www.theguardian.com/world/2014/jan/20/ evidence-industrial-scale-killing-syria-war-crimes.

Crimes against Humanity by Syrian Security Forces, Human Rights Watch, accessed on 16 February, https:// www.hrw.org/report/2011/06/01/weve-never-seen-suchhorror/crimes-against-humanity-syrian-security-forces. Death by Chemical, accessed on 19 February, https://www.hrw. org/report/2017/05/01/death-chemicals/syrian-governments-widespread-and-systematic-use-chemical-weapons.

End the horror in Syria's torture prisons, Amnesty International, accessed on 22 February, https://www.amnesty. org/en/latest/campaigns/2016/08/syria-torture-prisons/. German police arrest Syrian doctor for 'crimes against humanity', accessed on 19 February 2021, https://www. dw.com/en/german-police-arrest-syrian-doctor-forcrimes-against-humanity/a-53895002.

Germany: Syria Torture Trial Opens, accessed on 19 February 2021, https://www.hrw.org/news/2020/04/23/germany-syria-torture-trial-opens. 
Ghany F.A., The tale of enforced disappearances in Syria, accessed on 19 February 2021, https://voelkerrechtsblog. org/99000-disappeared-and-counting/.

Hirst D., Hezbollah uses its military power in a contradictory manner, accessed on 15 February 2021, http:// www.dailystar.com.lb/Opinion/Commentary/2012/ Oct-23/192380-hezbollah-uses-its-military-power-ina-contradictory-manner.ashx\#axzz2AJrVn2Ik.

Karacaoglu B., Karaahmet A., Emre Ozcan E., Syrian woman tells of torture she suffered in regime prisons, accessed on 23 February, https://www.aa.com.tr/en/middle-east/ syrian-woman-tells-of-torture-she-suffered-in-regimeprisons/2291206.

Karacaoglu B., Ahmet Karaahmet A., Journalists expose Assad regime at cost of their lives, accessed on 16 February 2021, https://www.aa.com.tr/en/middle-east/journalistsexpose-assad-regime-at-cost-of-their-lives/2105180.

New York Times, Ben Hubbard, accessed on 26 February 2021, https:/www.nytimes.com/2020/11/12/world/ middleeast/12syria-refugees-assad.html.

Raed Fares, accessed on 16 February 2021, https://en.wi kipedia.org/wiki/Raed_Fares_(activist).

Reuters, Major events in Egypt since the Arab Spring uprisings, Reuters Staff, accessed on 15 February 2021, https://www.reuters.com/article/egypt-uprising-anniversary-idUSL8N2JT1FE.

See more: Foreign involvement in the Syrian civil war, accessed on 15 February 2021, https://en.wikipedia.org/ wiki/Foreign_involvement_in_the_Syrian_civil_war\# Hezbollah.

Syria emergency, accessed on 23 February 2021, https:// www.unhcr.org/syria-emergency.html. 
Syria report 2020, Freedom House, accessed on 25 February: https://freedomhouse.org/country/syria/freedomworld/2021.

Syria: 'Hundreds of thousands' join anti-Assad protests, BBC, accessed on 19 February, https://www.bbc.co.uk/ news/world-middle-east-13988701.

Syria: Events of 2018, accessed on 19 February, https://www. hrw.org/world-report/2019/country-chapters/syria.

Syria: Families left alone to find answers about disappeared relatives, https://www.amnesty.org/en/latest/news/2019/ 08/syria-families-left-alone-to-find-answers-about-disappeared-relatives/.

Syria: Fears for Life of Free Expression Advocate, accessed on 16 February 2021, https://www.hrw.org/news/2015/11/20/ syria-fears-life-free-expression-advocate.

Syria: Freedom House, accessed on 16 February 2021, https://www.justice.gov/eoir/page/file/1186516/download.

Syria: Human Slaughterhouse: Mass Hangings and Extermination at Saydnaya Prison, Syria, https://www.amnesty. org/en/documents/mde24/5415/2017/en/.

Syria: Rising Toll in Homs, Human Rights Watch, accessed on 17 February, https://www.hrw.org/news/2011/07/02/ syria-rising-toll-homs.

Syria: Stories Behind Photos of Killed Detainees, Human Rights Watch, accessed on 21 February, https://www. hrw.org/news/2015/12/16/syria-stories-behind-photoskilled-detainees.

Syria: Who's involved, and what do they want? Scott Lucas and others, accessed on 23 February, https://theconversation.com/syria-whos-involved-and-what-do-theywant-95002. 
Syrian and Russian Strikes on Civilian Infrastructure, $\mathrm{Hu}-$ man Rights Watch, accessed on 21 February, https:// www.hrw.org/report/2020/10/15/targeting-life-idlib/ syrian-and-russian-strikes-civilian-infrastructure.

Syrian artists standing against tyranny, Freemuse, accessed on 19 February, https://freemuse.org/news/syrian-artists-standing-against-tyranny-2/.

Syrian doctor arrested in Germany for alleged crimes against humanity, accessed on 19 February 2021, https://www. theguardian.com/world/2020/jun/22/syrian-doctor-arrested-germany-alleged-crimes-against-humanity.

Syrian refugees flee Lebanon camp after tents set on fire, accessed on 24 February 2021, https://www.theguardian. com/world/2020/dec/27/syrians-refugees-flee-lebanoncamp-after-tents-set-on-fire.

Syrian Women and the Refugee Crisis, Yumna Asaf, accessed on 22 February 2021, https://www.mdpi.com/20760760/6/3/110.

Syrian Women, accessed on 22 February 2021, https://www. icrc.org/en/where-we-work/middle-east/syria/syrianwomen.

Syrians Deported by Lebanon Arrested at Home, accessed on 26 February 2021, https://www.hrw.org/news/2019/09/02/ syrians-deported-lebanon-arrested-home.

Tarabay J., For many Syrians, the story of the war began with graffiti in Dara'a, CNN, accessed on 16 February, https:// edition.cnn.com/2018/03/15/middleeast/daraa-syriaseven-years-on-intl/index.html.

Ten Years On the Homs Clock Tower Massacre, the Syrian Human Rights Committee, accessed on 19 February, https://www.shrc.org/en/?p=33831.

The Intercept - How the Assad Regime Tracked and Killed 
Marie Colvin for Reporting on War Crimes in Syria, Jonny Dwyer and Ryan Gallagher, accessed on 17 February 2021, https://theintercept.com/2018/04/09/mariecolvin-syria-assad/.

The Syria Justice and Accountability Centre (SJAC), page 14, accessed on 15 February, https://syriaaccountability. org/wp-content/uploads/Walls-Have-Ears-English.pdf. Turkey: Nearly 100,000 unregistered Syrians removed from Istanbul, accessed on 24 February 2021, https://www. dw.com/en/turkey-nearly-100000-unregistered-syriansremoved-from-istanbul/a-51888092.

Turkey: Syrians Being Deported to Danger, accessed on 24 February 2021, https://www.hrw.org/news/2019/10/24/ turkey-syrians-being-deported-danger.

UN Syria envoy says constitutional talks in peril, Stephanie Nebehay, accessed on 26 February 2021, https://www. reuters.com/article/us-syria-un-idUSKBN29Y2G1.

Violence against Women, Bleeding Wound in the Syrian Conflict, accessed on 22 February 2021, https://euromedrights.org/wp-content/uploads/2015/03/Doc-reportVAW-Syria1.pdf.

Vohra A., Deadly Welcome Awaits Syria's Returning Refugees, https://foreignpolicy.com/2019/02/06/a-deadlywelcome-awaits-syrias-returning-refugees/.

Zaatari Refugee Camp - Factsheet, May 2020, accessed on 24 February 2021, https://reliefweb.int/report/jordan/ zaatari-refugee-camp-factsheet-may-2020. 


\section{Renata Gałaj-Dempniak}

University of Szczecin

ORCID ID: https://orcid.org/0000-0001-9006-6633

\section{Human Rights in Asia: the Practical Implementation on the Example of Japan}

Japan is one of the Asian countries where level of economic and cultural development is so high that it seems that it should have no problem with the implementation of human rights. However, its cultural predispositions and the current economic crisis aggravated by successive natural disasters are slowing down this process. The Japanese government is implementing the protection of human rights, although the pace and manner of operation are sometimes negatively perceived and assessed by Japanese citizens and human rights organizations. The citizens themselves accuse the authorities of selective treatment of these rights. There are no domestic human rights institutions in the country. Japan has been a member of the United Nations Human Rights Council since 2017. In October 2019, she was re-elected to the UNHRC ${ }^{1}$. The government has different approaches to reports and reminders from the public and international as well as nongovernmental organizations. A number of steps have been taken to implement these rights. However, there are areas in which the process is slow and this is probably why the same accusations have been repeated for many years.

1 Ministry of Foreign Affair of Japan https://www.mofa.go.jp/mofaj/ press/release/press4_007933.html [access: 10.11.2020]. 
Citizens of this country have the opportunity to take advantage of actions encouraging them to defend their rights and they do so. Acts in their case are also taken by outsiders, who are granted the right to stay and work when they are violated. The government must take this activity into account. Currently, assistance in the field of information on human rights can be obtained by the Japanese society from several organizations operating in this country. These include: Human Right Watch, ${ }^{2}$ Amnesty International Japan, ${ }^{3}$ Human Rights Now, ${ }^{4}$ Hurights Osaka, ${ }^{5}$ Lighthouse: Center for Human Trafficking Victims, ${ }^{6}$ Center for Prisoners' Rights Japan, ${ }^{7}$ Asia-Japan Women's Resource Center, ${ }^{8}$ Buraku Liberation and Human Rights Research Institute, ${ }^{9}$ Shimin Gaikou Centre, ${ }^{10}$ and Tokyo Metropolitan Human Rights Promotion Center ${ }^{11}$. According to activists and citizens of the state, there are several areas of life that require special

2 Human Right Watch, https://www.hrw.org/world-report/2019/ country-chapters/japan [access: 10.11.2020].

3 Amnesty International Japan, https://www.amnesty.or.jp/ [access: 10.11.2020].

4 Human Rights Now, https://hrn.or.jp/eng/ [access: 10.11.2020].

5 Hurights Osaka, https://www.hurights.or.jp/english/ [access: 10.11.2020].

6 Lighthous, https://lhj.jp/index.html [access: 10.11.2020].

7 Center for Prisoners' Rights Japan, http://www.cpr.jca.apc.org/ about/outline_en [access: 10.11.2020].

8 Asia-Japan Women’s Resource Center, http://www.ajwrc.org/eng/ [access: 10.11 .2020$]$.

9 Buraku Liberation and Human Rights Research Institute, https:// blhrri.org/old/blhrri_e/blhrri/about.htm [access: 10.11.2020].

10 Shimin Gaikou Centre, http://shimingaikou.org/ [access: 10.11.2020].

11 Tokyo Metropolitan Human Rights Promotion Center, https:// www.tokyo-jinken.or.jp/english/index.html [access: 10.11.2020]. 
attention due to frequent violations of human rights. Only a few of them are presented in the paper.

For example, Japan lacks legislation prohibiting racial, ethnic, and religious discrimination as well as on the grounds of sexual orientation or gender identity. This is indicated by the topics covered both by the media and reports prepared by human rights activists.

People with disabilities are discriminated in accessing the labour market, although there is a law on employment protection for them. ${ }^{12}$ The law for employment in government institutions, unfortunately, is not working properly. ${ }^{13}$ The government is also accused of discriminating against and acting to the detriment of the victims of the tsunami and the explosion of the Fukushima nuclear power plant, as well as those subjected to forced sterilization under the eugenic protection act in 1948-1996. In May 2019, a cross-party committee was established to draft a law the task of which would be to create the basis for awarding compensation to the last of the above-mentioned groups, Shinzo Abe's government apologized to victims of forced sterilization. In the case of those injured in 2011, however, it does a lot to help, especially in terms of medical care. Many of the problems that emerged in 2011 are difficult to eliminate, and they affect huge numbers of people. One of them is the issue of contaminated water. In April, the Ministry of Foreign Affairs received a joint com-

12 Forcibly sterilized individuals have sued the government for compensation. Disability Rights, Human Right Watch, https://www.hrw.org/ world-report/2019/country-chapters/japan [access: 10.11.2020].

13 In August 2019, it was revealed that officials in major government agencies (the National Tax Agency, the ministries of justice, foreign affairs, transport) overstated the number of employees with disabilities. 
muniqué from four UN Special Rapporteurs. It concerns the management of contaminated water and the handling of ALPS treated water at the Tokyo Electric Power Company Holdings Fukushima Daiichi. ${ }^{14}$ In August, the government responded to the report explaining steps taken in the areas of: pollution removal, protection of the people working in it, and restoration of the environment.

Despite the government's declaration of desire to create equal opportunities for work and education for women and men, women continue to face discrimination. In 2016, a law promoting gender equality was passed. ${ }^{15}$ In May 2019, the first national law was introduced, encouraging political parties to nominate an equal number of candidates of both genders in elections. Institutions that declare equal treatment of women and men are awarded grants (e.g. female students at universities). ${ }^{16}$

Japan has passed a comprehensive law prohibiting sexual discrimination. However, its application is limited. The rape law was reformed in 2017, but it still falls short of international standards. There is no law at national level against discrimination on the basis of sexual orientation and gender identity. It was not until 2019 that the Tokyo city authorities

14 Response to the Joint Communication from four UN Special Rapporteurs from the Government of Japan concerning ALPS treated water at the TEPCO's Fukushima Daiichi Nuclear Power Station, https://www. mofa.go.jp/fp/hr_ha/page4e_001067.html [access: 10.11.2020].

15 Japan announced the Development Strategy for Gender Equality and Women's Empowerment.

16 Furthermore, since 2014, Japan has hosted the World Assembly for Women (WAW!), inviting female leaders and male supporters who are active in various fields and provide support for women, from home and abroad. Japan has been making proposals toward the realization of "Asociety where all women shine"..., Japan's Human Rights Commitments and Pledges, https://www.mofa.go.jp/files/000175306.pdf [access: 10.11.2020]. 
were the first to adopt a law on non-discrimination against LGBT people and on the basis of gender identity at the prefecture level. It does not constitute grounds for prosecution, but it is an incentive to counteract discrimination against this group of people. As it also applies to schools, it gives hope that the younger generations will approach the issue of tolerance in terms of sexuality differently. In Japan, an antiquated and discriminatory legal gender recognition law still applies.

Children have now become the object of increased state concern. In 1999, an act was adopted on the punishment of activities related to child prostitution and child pornography and the protection of children. ${ }^{17}$ It has been amended twice since then. In the opinion of the Tokyo branch of Human Rights Now, the implementation of the act is limited. ${ }^{18}$ In 2016, the Act on childcare was implemented, but it was not until July 2019 that the government decided to implement the principle of "family care" contained in the above-mentioned Act. It guarantees, among others, the adoption and foster care of children who cannot live with their biological parents. It determines the conditions for placing children in care facilities in the event of family failure. It has been announced that the number of child welfare officers to control the way childcare is performed will increase by 2022. Japan,

17 Act on Punishment of Activities relating to Child Prostitution and Child Pornography and the Protection of Children, 1999, Revised in 2004, 2014.

18 Media reports on HRN's investigations on child pornography in Japan, https://hrn.or.jp/eng/news/2017/08/28/media-child-pornography/ [access: 10.11.2020]; E. Ross, Child Abuse and Child Pornography Cases Hit Record Highs in 2016, "Newsweek", 17.03.2017, https://www. newsweek.com/child-pornography-and-child-abuse-japan-highest-everlevels-566082 World [access: 10.11.2020]. 
like most other countries, has problems with minors. This applies to, among others, the phenomenon of "Enjo Kosai", or taking money by minors from men in exchange for sexual services. The UN Human Rights Council has dealt with the issue, but its findings included in the report outraged the government by saying that $13 \%$ of Japanese girls had such experiences. Foreign Minister Kishida requested the UNHCR Special Rapporteur to disclose the sources on which the report was drawn up. The representatives of the Japanese government decided that it was unacceptable to make such comments without being supported by documented facts. Such accusations could have serious repercussions for the state. ${ }^{19}$ In the end, it turned out that the statement of the UNHCR representative was in fact not supported by evidence, which should not have been the case, as it weakens the credibility of the UN representatives in the future, making them suspicious of their actions and weakening the willingness to cooperate. The question remains, however, whether the Japanese government has tackled the scale of this phenomenon and will be able to stop it. This phenomenon occurs all over the world. Its roots lie in the impossibility of satisfying all the needs and whims of children who, observing their richer friends and the commercialized world, are ready to take up any challenge to get money for their dream objects or way of life. Countermeasures are taken in each country, but no recipe for eliminating the phenomenon has been found so far.

19 January 19, 2016 (PM), Press Conference by the Chief Cabinet Secretary (Excerpt), https://japan.kantei.go.jp/tyoukanpress/201601/19_p. html [access: 10.11.2020]; Report on Child Pornography in Japan, Human Rights Now, http://hrn.or.jp/eng/wp-content/uploads/2018/02/ HRN-Child-Pornography-Report-2018.02.07.pdf [access: 10.12.2020]. 
The country is also criticized for its particularly repressive refugee admission system. In 2019, there were 2.8 million foreigners in Japan. While Shinze Abe was the Prime Minister, the "Foreign Technical Intern Training" program was expanded..$^{20}$ The changes were to enable, among others, to recruit more foreign workers. During the internships, which could last five years, these people were to gain experience and knowledge while working in Japan. Undoubtedly, some of them might have wanted to stay in the country for longer, which meant recruiting a trained worker. However, the program was accused of thee unequal treatment of employees coming from abroad. Their rights are violated in terms of equal pay for work, and also by not paying part of overtime, as well as unsafe or unsanitary working conditions. The program contains provisions protecting the rights of the arrivals, but they are sometimes violated. Japan's asylum and refugee system remains strongly oriented towards giving refugee status. Each year, only a handful of

20 The aim of this program is to promote international cooperation as well as to help developing countries by sharing with them skills, technology and knowledge developed in Japan. Interns in companies in Japan acquire knowledge that is not available in their own country. It was announced on November 28, 2016, and entered into force on November 1, 2017. It was implemented under the Immigration Control and Recognition Act (Law No. 319 of 1951)., Japan International Trainee \& Skilled Worker Cooperation Organization, https://www.jitco.or.jp/en/ regulation/index.html [access: 8.11.2020]. See also: Foreign Technical Intern Training Program, https://jopus.net/en/glossary/technical-intern-training-program [access: 13.12.2020]; What is the Technical Intern Training Program for Foreigners? An easy-to-understand explanation of the new system!, https://manabink.com/en/2020/05/05/what-is-the-technical-intern-training-program-for-foreigners-an-easy-to-understand-explanation-of-the-new-system/ [access: 10.11.2020]; Address issues in the technical intern program, "The Japan Times", 21.11.2018, https://www. japantimes.co.jp/opinion/2018/11/21/editorials/address-issues-technical-intern-program/ [access: 1.12.2020]. 
applicants who have been granted refugee or asylum status by the Ministry of Justice are granted permission to enter and stay in the country.

There are allegations that immigration, criminal and psychiatric institutions practice arbitrary detention in Japan, leading to serious human rights violations. In terms of the detention of immigrants, the most frequent issues are: extending the time of detention of foreigners in immigration centres without a visa, the deterioration of health of detainees due to difficulties in continuing treatment, and "unjustified" detention. ${ }^{21}$

The justice system upholding the death penalty is also criticized. The opponents of capital punishment fear that those sentenced to this penalty "do not have adequate access to legal aid and are notified of the sentence only on the day of its execution."22 It is an ultimate punishment and its effects are irreversible. The perceived abuses concern arrests by the police (foreigners and citizens). These include, among others, refusing to consent to attorney's participation in the questioning, interrogations lasting many hours under strong pressure, prolonging the detention in custody without charges, not being able to get bail, tolerating detention without contact with family or friends, lack of health care. There are still other abuses in prisons, e.g. too often

21 In the case of immigration detention, there is a lack of both judicial control of detention and of the prescribed period of detention on the basis of a deportation order, as well as of rules on indefinite detention, detention of asylum seekers and control of dismissals. HRN Releases Statement Calling for the Prohibition of Arbitrary Detention in Immigration Facilities in Japan and Related Legal Reforms, https://hrn.or.jp/eng/ news/2019/10/31/immigration_reform_statement/ [access: 10.11.2020].

22 Death Penalty, Human Right Watch, https://www.hrw.org/ world-report/2019/country-chapters/japan [access: 8.11.2020]. 
and unreasonably used isolation, a drastic system of penalties and too rare use of early release. According to specialists, such actions negatively affect both the mental health and the general condition of detainees and prisoners. ${ }^{23}$

In the case of psychiatric care, arbitrary detention concerns the widely used forced hospitalization, even in cases not requiring a stay in the center, as well as the lack of proper procedures to remedy the infringed patient's rights.

Although these problems have long been the subject of analysis and recommendations to the Japanese authorities by the UN Human Rights Council and the UN Human Rights bodies, they have never been satisfactorily addressed. Japan has not yet kept international standards in this matter. Supporting civil society activities, Human Rights Now with 9 other organizations urged the Japanese government to accept the visit and cooperate with the United Nations Working Group on Arbitrary Detention, and when recommendations are issued to implement them. ${ }^{24}$ Japan has already officially received such a request twice (2015 and 2018), but the Group has not been accepted, despite the fact that, as a member of the UNHRC, it has an obligation to remove all obstacles to enable committee representatives to work. In 2019, the Japanese Federation of Bar Associations supported

23 "These treatments all violate Article 7, 9, 10 and 14 of the International Covenant on Civil and Political Rights (the "ICCPR")", Joint Statement to Urge the Japanese government to immediately accept the Country Visit by The UN Working Group on Arbitrary Detention, https:// hrn.or.jp/eng/wp-content/uploads/2020/01/Joint_Statement_Japan_Arbitrary_Detention.pdf [access: 15.11.2020].

24 RN Issues a Joint Statement Urging the Government of Japan to Accept a Country Visit by the UN Working Group on Arbitrary Detention, https://hrn.or.jp/eng/news/2020/01/22/joint-statement-japan-arbitrary-detention/, 22.01.2020 [access: 8.11.2020]. 
these efforts, demanding that the government take immediate action to eliminate the practice of arbitrary detention.

This raises the question of whether the Japanese government responds to the allegations. The answer is "yes", but it does it slowly and it most often speeds up actions when the situation becomes drastic (deaths, hunger strikes). The Minister of Justice announced the establishment of a Detention and Deportation Commission as part of the advisory body of the $7^{\text {th }}$ Immigration Control Planning Meeting and the start of discussions on the reform of immigration law. ${ }^{25}$

He also takes various initiatives, especially outside. In 2020, "Japanese Initiative in the Efforts to Eliminate Discrimination against Persons Affected by Leprosy and Their Family Members" was presented. ${ }^{26}$ In Japan, the "Leprosy Prevention Act", which contained a provision on isolation, was abolished in 1996 when the state officials recognized that the disease became curable and thus isolation of patients and their families was no longer necessary. The Land of the Rising Sun has made efforts to abolish similar restrictions around the world. Japan submitted a number of resolutions to the Human Rights Council in 2008, 2009, 2010, 2015, 2017 as part of the Open a New Window initiative. The 2020 initiative presented on behalf of 8 countries $^{27}$ is called: Open a New Window to the HRC.

The Japanese government says it pursues diplomacy based on the fundamental values of freedom, democracy,

25 Press Conference by the Minister of Justice (1 October 2019), http://www.moj.go.jp/EN/hisho/kouhou/press_h31.html [access: 10.11.2020].

26 Japanese Initiative in the Efforts to Eliminate Discrimination against Persons Affected by Leprosy and Their Family Members, https:// www.mofa.go.jp/fp/hr_ha/page22e_000675.html [access: 10.11.2020].

27 Brazil, Ecuador, Ethiopia, Fiji, India, Japan, Morocco and Portugal. 
human rights and the rule of law. However, there are allegations of diplomatic actions inconsistent with this declaration. An example is the participation of former Japanese diplomat Kenzo Oshima in Burma. ${ }^{28}$ His actions prevented the establishment of an independent investigative mechanism. Another example is electoral aid to Cambodia, whose government clearly violated the rules of democratic elections and took over all seats in parliament. ${ }^{29}$ Japan did not join the wave of post-election criticism in this case.

The country's authorities will probably have to deal in some form with the effects of supporting the "Paradise on Earth" campaign (1959-1984), urging Koreans to emigrate and move to North Korea. ${ }^{30}$ The case of Japanese citizens of Korean descent and their fate after succumbing to the propaganda of an organization inviting them to come to North Korea became the subject of work conducted by the United Nations in 2003. It gained publicity thanks to the actions of the victims themselves. Tessa Morris-Suzuki in "Exodus to North Korea: Shadows from Japan's Cold War"31 accused of

28 In 2017, on the abuses of Rohingya militants and Myanmar security forces.

29 Before the elections, the Cambodian government disbanded the main opposition party, used harsh repression against civil society, opposition politicians and independent media. Japan provided Cambodia with about 7 million dollars. The funds were received, among others, by Cambodia National Election Committee, which was a biased body. Under international pressure to not legitimize the rigged elections, Tokyo announced that it would not be sending an official election observation mission. However, it did not condemn the elections themselves.

30 It was run by the General Association of Korean Residents in Japan. K. Doi, No "Paradise on Earth": Why Japan Should Right a Historic Wrong. Tokyo for years supported a program that condemned many to hell on earth, https://www.hrw.org/news/2015/09/22/no-paradise-earth-whyjapan-should-right-historic-wrong [access: 10.11.2020].

31 Lanham 2007. 
complicity also the Japanese Red Cross and the International Committee of the Red Cross. The author accuses the organization of supporting this campaign. ${ }^{32}$ The Japanese authorities are accused of failing to halt the campaign, despite their knowledge of the fate of emigrants, and of legitimizing migration by granting travel permits. In 2015, North Korean refugees applied to the Japan Federation of Bar Associations to initiate human rights protection and enforcement activities for those affected by this migration. The Federation of Bar Associations took up the challenge by forming a group to investigate the problem.

Ethnic groups permanently residing in Japan also have a problem with enforcing their rights. They demand full rights and an end to discriminatory practices. Japan is seen as a country that does not pay attention to the assimilation of other ethnic groups, nor does it recognize Japanese native cultures. In 1997, the "Ainu Cultural Revival" Act was passed to replace the previous law ("Hokkaido Former Aboriginal Protection”). In 2008, the Japanese parliament passed a resolution that recognized the Ainu as indigenous people. In 2019, the "Ainu Promotion Act" was adopted, which gave them full rights to cultivate their own tradition. The National Ainu Museum and Park was established in Hokkaido in 2020. ${ }^{33}$ The Ainu people, however, are not satisfied with the regulations concerning education and their traditional crafts. The Riukiu (Ryuku) people seek similar

32 "Paradise on Earth" was an international campaign organized by Japan and North Korea's Red Cross associations, with the support of the International Committee of the Red Cross, which lured thousands of ethnic Koreans living in Japan and their families with false promises to leave their homes and go to North Korea. K. Doi, op.cit.

33 National Ainu Museum, https://ainu-upopoy.jp/en/facility/museum/ [access: 10.11.2020]. 
treatment. ${ }^{34}$ The current government position on the matter is that, apart from the Ainu people, there are no other groups that qualify as indigenous peoples. The United $\mathrm{Na}-$ tions Human Rights Council (UNHRC) has tried unsuccessfully several times to encourage the Japanese government to address the problem, but the position of the Japanese authorities is intransigent. ${ }^{35}$

This problem is compounded by the lack of legislation explicitly prohibiting discrimination and the use of hate speech. This results in complaints of unequal treatment, especially of foreigners in public places, institutions, and enterprises, as well as discrimination in terms of earnings. ${ }^{36}$ The government recognizes the society as ethnically homogeneous, with deeply entrenched customs and distinct identity. Since native peoples have problems with acceptance, it is even more difficult to change the way they approach strangers. Probably the current migration crisis in the world and the pandemic only deepen the negative attitude towards changes.

In 2020, the Olympic and Paralympic Games were to be held in Tokyo. Due to the pandemic, they were postponed.

34 Ryukyuans (Okinawod) - Minority Rights Group, https://minorityrights.org/minorities/ryukyuans-okinawans/[access: 10.11.2020].; International Covenant on Civil and Political Rights Alternative Report Submission: Violations of Indigenous Peoples' Rights in Japan Prepared for 128th Session, Geneva, 2 March-27 March, 2020, https://www.culturalsurvival.org/sites/default/files/ICCPR-Japan-Report-2020-FINAL. pdf [access: 15.12.2020].

35 June 21, 2016 (AM), Press Conference by the Chief Cabinet Secretary (Excerpt), https://japan.kantei.go.jp/tyoukanpress/201606/21_a. html [access: 10.11.2020].

36 Joint Civil Society Report Racial Discrimination in Japan, pdf, https://tbinternet.ohchr.org/Treaties/CERD/Shared\%20Documents/JPN/ INT_CERD_NGO_JPN_31918_E.pdf [access: 10.11.2020]. 
It should be noted that the Tokyo 2020 Organizing Committee was the first in the world to pledge compliance with the United Nations Guiding Principles on Business and Human Rights. According to the UNGP, the organizing committee will have to investigate, know and prevent threats to human rights, ensure countermeasures and transparency throughout the process. As early as in 2015, the Japanese Federation of Bar Associations published the "Guidance on Human Rights Due Diligence" for Japanese lawyers and companies. This was to facilitate making employers and lawyers aware of human rights. ${ }^{37}$ Japanese lawyers can advise companies, support victims of human rights violations, and assist them in seeking redress. They can indicate gaps in the law on human rights issues in the business sector. In 2018, lawyers launched the BHR Lawyers Network Japan in response to a call from the United Nations Working Group on Business and Human Rights to establish a global network of pro-bono lawyers at BHR. It is an information exchange network. In 2020, the BHR Lawyers Network began implementing the BHR training program for Japanese lawyers in cooperation with the International Bar Association. In the same year, Japanese lawyers affiliated with the Business and Human Rights Lawyers Network Japan founded the Japan COVID-19 \& BHR Research Project to investigate the impact of the pandemic on the position of Japan's most vulnerable social groups to labour market fluctuations. ${ }^{38}$ The research con-

37 D. Takahashi, Roles of lawyers in preventing business-related human rights abuses in Asia Pacific, BHR Lawyers, https://www.bhrlawyers. org/unforum2020 [access: 15.12.2020].

38 D. Takahashi, Japan: promoting the respect of human rights by business during the Covid-19 crisis, https://www.ibanet.org/Article/ NewDetail.aspx?ArticleUid=c4369e58-d011-4da0-9956-742fb8b42a46 [access: 12.11.2020]. 
cerned, among others its impact on life: economic emigration, casual or part-time workers performing work, workers with permanent employment, employees of concerns, health care workers, self-employed workers, children, the elderly, women, disabled people, foreigners. It turned out that the pandemic often resulted in a loss of income for these groups as well as in the violation of their rights by not providing them with any form of protection. Women, single mothers and refugees are the most numerous among these groups. It is among them that the greatest number of cases of living in poverty and homelessness was recorded. Foreigners and wage earners in Japan found themselves in a new situation. They faced problems with the local language - most of the news and advice on measures to be taken was initially only given in Japanese. The Japanese government recognized the problem of the infringement of rights in access to information and began to publish the most important ordinances also in other languages. The Ministry of Justice ordered the publication of basic information on labour rights for foreigners in foreign languages. One of the most serious problems during the pandemic was the restriction of the departure and re-entry into the country of foreigners, including those who had worked in Japan for years, which deprived them of the possibility of working and earning money. Such restrictions were also introduced by many other countries. The problem arose from the unequal treatment of Japanese citizens who had the freedom to travel and foreigners who were affected by restrictions. ${ }^{39}$ Due to the intervention of business representatives, in September 2020, the government relaxed the regulations in relation to those working in Japan.

39 Supply chains migrant workers guidelines, BHR Lawyers, https:// www.bhrlawyers.org/ en-migrantworkers [access: 10.11.2020]. 
Some allegations are also provoked by the inconsistency in the enforcement of the law on training by the state authorities necessary to perform work. The drive to improve the working environment of migrant workers stems from corporate human rights obligations (UN Guiding Principles on Business and Human Rights) and the principle of "leave no one behind" (UN Sustainable Development Goals: promoting decent work, sustainable production and consumption). In May 2020, the Business and Human Rights Lawyers Network Japan formulated basic rules of conduct during the pandemic, aimed at promoting innovative and responsible business behaviour that will save workers, better protect their rights and, consequently, allow the industry to recover from the pandemic quickly. Japan was the first country in the world to undertake a National Action Plan, which aims to maximize the positive impact of business on human rights. The government agreed to include issues related to the impact of the pandemic on human rights. It is difficult to say how far it is ready to get involved in this matter.

On the website of the Ministry of Foreign Affairs of Japan, there is information about the government's activities in the field of human rights protection at home and abroad. It is emphasized that the aid given to Japan by many countries in 2011 is appreciated. Therefore, despite internal difficulties, Japan has developed the project "Humanitarian Aid Policy of Japan", and is consistently trying to implement it. ${ }^{40}$ Japanese representatives emphasize that they respect and promote human rights and constantly work to implement them both in their own country and in the world. ${ }^{41}$ This is

40 Humanitarian Assistance / Emergency Assistance, https://www. mofa.go.jp/policy/emergency/index.html [access: 10.11.2020].

41 "Upholding the highest standards of human rights enshrined and 
evidenced by the conventions and agreements to which it has acceded and has undertaken to respect and implement them: the International Covenant on Economic, Social and Cultural Rights, ${ }^{42}$ the International Covenant on Civil and Political Rights, ${ }^{43}$ the Convention on the Elimination of All Forms of Discrimination against Women ${ }^{44}$, the Convention on the Rights of the Child, ${ }^{45}$ the International Convention on the Elimination of All Forms of Racial Discrimination, ${ }^{46}$ the Convention against Torture and Other Cruel, Inhuman or Degrading Treatment or Punishment, ${ }^{47}$ the International Convention for the Protection of All Persons from Enforced Disappearance, ${ }^{48}$ the Convention on the Rights of Persons with Disabilities. ${ }^{49}$ Japan has undertaken to abide by the Geneva Conventions and its Additional Protocols, the Refugee

guaranteed in its Constitution, Japan has consolidated its democratic political system and developed policies for the promotion and protection of human rights and fundamental freedoms as universal values. Japan firmly believes that the promotion and protection of all human rights is a legitimate interest of the international community. Therefore, grave violations of human rights need to be addressed in cooperation with the international community. Japan also affirms that the human rights of all people should be respected, regardless of their countries' cultures, traditions, political and economic systems and levels of socio-economic development, even if there are differences in their processes and speed of achievement with regard to human rights protection. Protecting human rights is the most fundamental responsibility of any nation..., Japan's Human Rights Commitments and Pledges, https://www.mofa.go.jp/files/000175306.pdf [access: 15.12.2020].
42 In 1979.
43 In 1979.
44 In 1985.
45 In 1994.
46 In 1995.
47 In 1999.
48 In 2009.
49 In 2014. 
Protocols, the Hague Convention, ${ }^{50}$ the Palermo Convention $^{51}$ and the Protocol to Prevent, Suppress and Punish Trafficking in Persons, Especially Women and Children. Japan is seeking a constructive dialogue with the Office of the High Commissioner for Human Rights (OHCHR) and the special procedures under which it wants to offer its cooperation. According to the government document, Japan will work to clarify and implement the recommendations, but they must be properly documented. It will undergo the Universal Periodic Review of Human Rights. Japan is strengthening the health system under a project established in September 2015, and action preventing violence against children and sexual harassment. In 2015, Japan established the Development Cooperation Charter, making human safety a guiding principle.

It is to be hoped that all declarations will be implemented for the benefit of all citizens of the country and visitors. Listening to the contents of the government's declarations, however, one notices a dissonance between intentions and reality. It often seems to stem from a lack of supervision over the administration. Sometimes, it is the result of a policy that has been pursued for years, which is difficult to change given historical or cultural conditions.

\section{Bibliography}

Address issues in the technical intern program, "The Japan Times", 21 November 2018, https://www.japantimes.co.jp/

50 Hague Convention in 1980, Convention on the Civil Aspects of International Child Abduction.

51 2017, UN Convention against Transnational Organized Crime. 
opinion/2018/11/21/editorials/address-issues-technical-intern-program/.

Death Penalty, Human Right Watch, https://www.hrw.org/ world-report/2019/country-chapters/japan.

Disability Rights, Human Right Watch, https://www.hrw. org/world-report/2019/country-chapters/japan.

Doi K., No "Paradise on Earth": Why Japan Should Right a Historic Wrong. Tokyo for years supported a program that condemned many to hell on earth, Human Rights Watch, 22 September 2015, https://www.hrw.org/ news/2015/09/22/no-paradise-earth-why-japan-shouldright-historic-wrong.

Forced Labor Risk in Japan's Technical Intern Training Program Exploration of Indicatorsamong Chinese Trainees Seeking Remedy, Verite, https://www.verite.org/wp-content/uploads/2018/09/Forced-Labor-Risk-in-JapansTITP.pdf.

Foreign Technical Intern Training Program, Jopus, https://jopus.net/en/glossary/technical-intern-training-program. Gałaj-Dempniak R., Pornografia dziecięca w Japonii. Stan wiedzy w polskich mediach i Internecie (1998-2016) [Child Pornography in Japan. The State of Knowledge in the Polish Media and the Internet (1998-2016)], [in:] Azja, edukacja, wychowanie, modernizacja społeczna [Asia, Education, Upbringing, Social Modernization], eds. J. Marszałek-Kawa, B. Mydłowska, K. Pierzchała, Toruń 2018.

Gałaj-Dempniak R., Prawa człowieka w Japonii w kontekście awarii elektrowni w Fukushimie i tsunami (obraz w mediach) [Human Rights in Japan in the Context of the Fukushima Power Plant Accident and the Tsunami (Image in the Media)], [in:] Polityczne i społeczne oblicza wspótczesnej Ja- 
ponii [Political and Social Faces of Contemporary Japan], eds. J. Marszałek-Kawa, M. Dahl, Toruń 2018.

Gałaj-Dempniak R., Problem uchodźców z japońskiej perspektywy, [The Refugee Iussu from the Japanese Perspective], [in:] Prawo i kultura we wspótczesnej Japonii [Law and Culture in Contemporary Japan], eds. J. MarszałekKawa, M. Bidziński, Toruń 2017.

HRN Releases Statement Calling for the Prohibition of Arbitrary Detention in Immigration Facilities in Japan and Related Legal Reforms, 31 October 2019, Human Rights Now, https://hrn.or.jp/eng/news/2019/10/31/immigration_reform_statement/.

Human Rights Violations in Okinawa, Japan (HRC31, 2016, Joint-WS), The International Movement Against all Forms of Discrimination and Racism, https://imadr. org/human-rights-violations-okinawa-japan-hrc312016-joint-ws/.

Humanitarian Assistance / Emergency Assistance, Ministry of Foreign Affair of Japan, https://www.mofa.go.jp/ policy/emergency/index.html.

International Covenant on Civil and Political Rights Alternative Report Submission: Violations of Indigenous Peoples' Rights in Japan Prepared for 128th Session, Geneva, 2 March-27 March, 2020, https://www.culturalsurvival.org/ sites/default/files/ICCPR-Japan-Report-2020-FINAL.pdf. Japanese Initiative in the Efforts to Eliminate Discrimination against Persons Affected by Leprosy and Their Family Members, 31 August 2020, Ministry of Foreign Affairs of Japan, https://www.mofa.go.jp/fp/hr_ha/page22e_000675.html.

Japan's Human Rights Commitments and Pledges, January 2019; https://www.mofa.go.jp/files/000175306.pdf. 
Joint Civil Society Report Racial Discrimination in Japan, August 2018, pdf, https://tbinternet.ohchr.org/Treaties/ CERD/Shared\%20Documents/JPN/INT_CERD_NGO_ JPN_31918_E.pdf.

Joint Statement to Urge the Japanese government to immediately accept the Country Visit by The UN Working Group on Arbitrary Detention, 20 January 2020, https://hrn. or.jp/eng/wp - content/uploads/2020/01/Joint_Statement_Japan_Arbitrary_Detention.pdf.

June 21, 2016 (AM), Press Conference by the Chief Cabinet Secretary (Excerpt), Prime Minister of Japan and His Cabinet, https://japan.kantei.go.jp/tyoukanpress/201606/21_a. html.

Media reports on HRN's investigations on child pornography in Japan, 28 August 2017, Human Rights Now, https://hrn. or.jp/eng/news/2017/08/28/media-child-pornography/.

Morris-Suzuki T., "Exodus to North Korea: Shadows from Japan's Cold War”, Lanham 2007.

Press Conference by the Minister of Justice (1 October 2019), Ministry of Justice, http://www.moj.go.jp/EN/hisho/ kouhou/press_h31.html.

Press Conference by the Chief Cabinet Secretary (Excerpt), Prime Minister of Japan and His Cabinet, https://japan. kantei.go.jp/tyoukanpress/201601/19_p.html.

Report on Child Pornography in Japan, 7 February 2018, Human Rights Now, http://hrn.or.jp/eng/wp-content/uploads/2018/02/HRN-Child-Pornography-Report-2018. 02.07.pdf.

Response to the Joint Communication from four UN Special Rapporteurs from the Government of Japan concerning ALPS treated water at the TEPCO's Fukushima Daiichi Nuclear Power Station, 12 June 2020, Ministry of For- 
eign Affairs of Japan, https://www.mofa.go.jp/fp/hr_ha/ page4e_001067.html.

$R N$ Issues a Joint Statement Urging the Government of Japan to Accept a Country Visit by the UN Working Group on Arbitrary Detention, 22 January 2020, Human Rights Now, https://hrn.or.jp/eng/news/2020/01/22/joint-statement-japan-arbitrary-detention/.

Ross E., Child Abuse and Child Pornography Cases Hit Record Highs in 2016, "Newsweek" 17 March 2017, https:// www.newsweek.com/child-pornography-and-childabuse-japan-highest-ever-levels-566082 World.

Ryukyuans (Okinawans) - Minority Rights Group, https:// minorityrights.org/minorities/ryukyuans-okinawans/.

Supply chains migrant workers guidelines, BHR Lawyers, https://www.bhrlawyers.org/ en-migrantworkers.

Takahashi D. Japan: promoting the respect of human rights by business during the Covid-19 crisis, International Bar Association the Global Voice of the legal Profession, https://www.ibanet.org/Article/NewDetail. aspx?ArticleUid =c4369e58-d011-4da0-9956-742fb$8 \mathrm{~b} 42 \mathrm{a} 46$.

Takahashi D., Roles of lawyers in preventing business-related human rights abuses in Asia Pacific, November 2020, BHR Lawyers, https://www.bhrlawyers.org/unforum2020.

What is the Technical Intern Training Program for Foreigners? An easy-to-understand explanation of the new system!, Manabink, https://manabink.com/en/2020/05/05/ what-is-the-technical-intern-training-program-for-foreigners-an-easy-to-understand-explanation-of-the-newsystem/. 


\section{Organization websites}

Amnesty International Japan, https://www.amnesty.or.jp/.

Asia-Japan Women's Resource Center, http://www.ajwrc. org/eng/.

Buraku Liberation and Human Rights Research Institute, https://blhrri.org/old/blhrri_e/blhrri/about.htm.

Center for Prisoners' Rights Japan, http://www.cpr.jca.apc. org/about/outline_en.

Human Rights Now, https://hrn.or.jp/eng/.

Human Right Watch, https://www.hrw.org/world-report/2019/country-chapters/japan.

Hurights Osaka, https://www.hurights.or.jp/english/. Japan International Trainee \& Skilled Worker Cooperation

Organization, https://www.jitco.or.jp/en/regulation/index.html.

Lighthouse: Center for Human Trafficking Victims, https:// lhj.jp/index.html.

Human Rights, Humanitarian Assistance, Refugees, Ministry of Foreign Affairs of Japan, https://www.mofa.go.jp/ policy/human/index.html.

ONZ, https://www.un.org/en/.

Shimin Gaikou Centre, http://shimingaikou.org/.

The Government of Japan, https://www.japan.go.jp/.

Tokyo Metropolitan Human Rights Promotion Center, https://www.tokyo-jinken.or.jp/english/index.html.

\section{Abstract}

Each country has its own way of dealing with social problems and the accompanying human rights violations. Japan is not free from these phenomena. They reveal themselves in many aspects of life: equal- 
ity before the law, work, medical care, justice, migration problems, youth issues, paedophilia, pornography, social care, etc. In most cases, the Japanese government is taking actions that are considered too slow. However, there are areas in which it does not intend to change the law at all, for example, to recognize the rights of the Okinawa people.

Keywords: Japan, human rights, law-abidingness 


\section{Anna Adamus-Matuszyńska \\ University of Economics in Katowice \\ ORCID ID: https://orcid.org/0000-0003-3234-4599}

\section{Third-Gender Rights in Asia}

Knowing who we are is a prerequisite for understanding who we are becoming. It is the foundation for self-building. ${ }^{1}$

\section{Introduction}

The modern, global world is a world in which identity plays a fundamental role. Today, a person wants to be accepted as he/she understands his/her individuality. Mentors, psychologists, therapists, and other active observers of the social world encourage people to discover themselves and be themselves. However, often behind such sayings there are advertising campaigns aimed at selling. ${ }^{2}$ As Giddens writes... to be a human being is to know, virtually all of the time, in terms of some description or another, both what one is doing and why one is doing it. ${ }^{3}$ Culture imposes on individual values and norms which - as Judith Butler writes - trigger and structure human reactions and 'produce' bodies. ${ }^{4}$

1 J. Siaud-Facchin, Trop intelligent pour être heureux?: L'adulte surdoué, trans. A.Adamus-Matuszyńska, Odile Jacob, 2008.

2 M. Klosow, Genderbedning. Praktyki przekraczania kulturowych norm ptci, Warsaw 2019, p. 449.

3 A. Giddens, Modernity and Self Identity. Self and Society in the Late Modern Age, Cambridge 1999, p. 35.

4 J. Butler, Zapiski o performatywnej teorii zgromadzeń, Warsaw 2016, p. 29. 
Sex has at least two biological and cultural dimensions; one does not function without the other, but it may happen that they are in conflict when they do not match. Without entering into a discussion on the definition of sex or gender, it should be noted that a person has a body and self-awareness, has biological features and own feelings about who he/ she is, who he/she feels, and how he/she wants to function in a world defined by culture before he/she is born.

The modern world is changing as dynamically as never before. The reason for this dynamics is social media, i.e., a faster, global and very open form of exchanging thoughts, opinions and judgments. Probably this openness of communication is one of the reasons for the increasing openness in communicating gender identity. The $20^{\text {th }}$ century practically did not give a chance to noticeably speak out all dilemmas related to this identity. The $21^{\text {st }}$ century makes this issue an important element of global as well as local public discourse.

The aim of this article is to analyse the relationship between human rights and third-gender acceptance. Sex and gender are two terms which have particular significance in the contemporary world, raising attention as well as anger depending on who is concerned.

Biological and cultural gender have been the subject of numerous studies and research for years. From the point of view of human rights, the most important thing is gender identity or the feeling of gender identity. That issue is essential due to individual and social identity, but at the same time difficult to describe (depending on the readiness of the respondents to make an open coming out), socially sensitive (there is still no society that fully accepts this social issue without any reservations) and still considered as controver- 
sial despite universal human rights, extensive research and the development of tolerance towards diversity.

\section{Identity - a key term in social sciences}

The issue of identity has been the subject of research in several disciplines for many years. ${ }^{5}$ The beginning of such an examination was provided by psychology, which, through research by Erik H. Erikson, introduced the term identity into the fields of social sciences and humanities in the 1950s. The American psychoanalyst understood identity as an effect of the process of mature personality integration. In his opinion, the sense of identity has two dimensions: an individual's relationship to himself/herself and an individual's relationship to other people. As Erikson argued, an individual's sense of identity is sustained by what others think of him/her. ${ }^{6}$ His definition of identity is not clearly explained, though. He stresses that individual identity is conscious, an individual strives for personal continuity, and he/she wants to be consistent with the group identity. ${ }^{7}$ The inventor of the theory of identity placed this term on the border of psychology and sociology, emphasizing the role and importance of social acceptance of identity. Identity is a certain form of self-definition which is the result of three dimensions of an individual's existence: the body, his/her aspirations and social roles. ${ }^{8}$ Erikson's understanding of identity influenced the further path of research and studies

\footnotetext{
5 T. Paleczny: Socjologia tożsamości, Kraków 2008.

6 E.H. Erikson, Tożsamość a cykl życia, Warsaw 2004, p. 20.

7 Idem, Dzieciństwo i społeczeństwo, Poznań 2000.

8 Encyklopedia socjologii, vol. 4, p. 253.
} 
on this issue. ${ }^{9}$ The issue was developed by Henri Tajfel, who discussed the subject of social identity, explicitly linking the term identity with the place of the individual in society. Under this concept, the British psychologist understands an element of the individual's image of himself/herself, resulting from the individual's knowledge of belonging to a social group (or groups), including the emotional meaning assigned to it. ${ }^{10}$ The identity of an individual is self-awareness in a specific society; it is the result of human life in society. As Tajfel further emphasizes, it is an individual's knowledge of belonging to a social group. There is no identity apart from the social context. ${ }^{11}$ One can distinguish a stable and transitory social identity. The former, practically impossible in the fluid social reality at present, would be typical for groups considered dominant. However, even in very traditional and conservative societies, there are changes that affect the identity of individuals. Therefore, identity always bears the hallmarks of impermanence, or, it should be noted - changeability. Globalization and social media influence numerous social processes, including hybridization, assimilation and acculturation, which are the result of multilateral interpersonal and intergroup interactions. ${ }^{12}$ Identity is not a natural state of an individual, it is the result of social processes that happen independently of him/her, giving the individual the opportunity to express himself/herself on the

9 A.S. Waterman, Identity, the Identity Statuses, and Identity Status Development: A Contemporary Statement, "Developmental Review" 1999, no. 19 , pp. 591-621.

10 H. Tajfel: Tożsamość społeczna i zachowanie międzygrupowe. „Przegląd Psychologiczny” 1976, vol. XIX, no. 2, p. 156.

11 Z. Mac: Preface to T. Paleczny, Socjologia, Kraków 2008, p. 7.

12 T. Paleczny: Socjologia tożsamości, op.cit., p. 135 and beyond. 
one hand, but on the other, due to the strong influence of cultural values and norms, causing alienation, marginalization or even depression.

The theory of identity is not a single, coherent concept, but rather a set of different theoretical approaches that try to give this concept, and, above all, a process, the framework for understanding the meaning and importance of identity in the contemporary world. A consequence of the psychological understanding of identity is its strong connection with social reality; it is the social group that de facto determines the sense of identification of a given individual. In sociology, before the use of the term identity, a similar idea was analysed using other terms. Charles Cooley developed the concept of the 'looking-glass self', and George H. Mead introduced the term 'the generalised other' into sociology. Sociology distinguishes at least four theoretical models of identity: the identity health model (maintaining the balance between the organism and the requirements of social life), the interactive identity model (identity as a result of the interaction of the individual with the environment), the worldview model of identity (identity as a set of permanent premises of self-perception arising in a given community), the ecological model of identity (identity as a research field analysing its formation). ${ }^{13}$ Significant elements for understanding identity were added by Anthony Giddens, who unequivocally stated that "the self is not a passive entity, determined by external influences. ${ }^{14}$ His concept is the theory of reflective consciousness, which indicates that people are

13 See: Z. Bokszański: Tożsamość, [in:] Encyklopedia socjologii, vol. 4, Warsaw 2002, pp. 252-255.

14 A. Giddens: Modernity and Self Identity. Self and Society in the Late Modern Age, Cambridge 1999, p. 2. 
constantly tracking the circumstances of their own actions and can explain the reasons for their occurrence. The British sociologist calls this activity practical awareness that gives people the security of existence, self-identity, so it answers the question: who am I in particular here and now, in a given society, in a specified group? The need to ask such a question is essential when one wants to explain his/her own actions as well as setting goals and actions for the future.

An important contribution to understanding the meaning of identity was made by Manuel Castells, for whom identity is the source of meaning and experience. The Spanish sociologist refers to the concept of process, noting that identity is the process of constructing a sense based on an attribute or a set of cultural attributes that is given priority over other sources of meaning. ${ }^{15} \mathrm{He}$ also recognizes that the identities of individuals can come from dominant institutions when they are internalized by social actors who give meaning to the process. ${ }^{16}$ Castells' thoughts have largely influenced the recognition of identity theory in social sciences. The author distinguishes three of its forms, and each of them is important for the operation of groups and individuals in society. The legitimizing identity - introduced by social institutions - creates civil society, the identity of resistance - built by social groups that are in a worse position than others - creates communities, and the identity of the project - arises in the processes of transformation and thus determines entities, i.e., self-aware individuals. The analysis of contemporary social, political and economic processes leads Castells to many conclusions about the processes of

15 M. Castells: Siła tożsamości, Warsaw 2008, p. 22.

16 Ibidem, p. 23. 
identity construction in the era of the network society. He emphasizes that social movements, especially those emerging from community resistance to globalization, capitalism and patriarchalism, are crucial factors. ${ }^{17}$ The other factors determining identity are networks characteristic of the new forms of organization, including social resistance movements. They are the "producers" of cultural codes affecting society and individuals who are not yet aware of this impact.

Empirical research reveals how identities are constructed. For example, research on workers revealed that group identity was created under the influence of the way the group is perceived by the external environment, the influence of technology on the perception of both opportunities and threats resulting from the need to think about the question of who these workers are. Moreover, research has shown that a group of workers has appropriated the technology and thus perceives this technology as a tool, a link and as a brand, which in turn allows them to build their own identity. ${ }^{18}$

The contemporary role and importance of identity have its consequences. First, identity arises because of internalizing the values characteristic of the social environment in which people live. Today, in the times of individualism and a strong value of creativity, we are dealing with a new type of creativity - creative identity. This is of particular importance in artistic, scientific and creative environments, where such identity is required. ${ }^{19}$ Identity in the post-modern

17 Ibidem, p. 385.

18 M. Boudreau, Ch. Serrano, K. Larson, IT-driven identity work: Creating a group identity in Digital environment, "Information and Organization" 2014, no. 24, pp. 1-24.

19 V.P. Glaveanu, L. Tanggaard, Creativity, identity, and representa- 
world is the crucial subject of scientific research in the $21^{\text {st }}$ century. Contemporary scholars notice the change of the identity sense towards greater reflection, subjectivity, and the possibility of constructing oneself, but also the obligation to take responsibility for one's own profile and image. ${ }^{20}$

Charles Tylor contributed to the contemporary implication of identity when he wrote that the first individual had to be freed from his/her social destiny, imposed on him/ her by his/her position in the social structure, which Tylor calls the egalitarian revolution. Then an individual must go through an expressionist revolution that gives him/her an individual way of existence, to allow the individual to make a self-definition. Summing up, Taylor writes that we must choose our identity. ${ }^{21}$ Our identity is shaped by recognition or its absence, and a person or group of people can suffer real damage if the society around him/her mirrors back to him/her the demeaning or contemptible picture of him/her. "Nonrecognition or misrecognition can inflict harm, can be a form of oppression, imprisoning someone in a false, distorted, and reduced mode of being. A person's identity depends on his/her dialogical relations with others." ${ }^{22}$ As Taylor further writes, everyone should be recognized for his/her unique identity, everyone has his/her own identity, one can form his/her identity through contact with significant others.

tion: Towards a socio-cultural theory of creative identity, "New Ideas in Psychology" 2014, no. 34, pp. 12-21.

20 M. Świątkiewicz-Mośny (2015), Konstruowanie nowych tożsamości w warunkach globalizacji, Kraków, p. 10.

21 Ch. Tylor, Źródła wspótczesnej tożsamości, [in:] Tożsamość w czasach zmiany. Rozmowy w Castel Gandolfo, Kraków 1995, p. 12.

22 Ch. Tylor, The Politics of Recognition, [in:] Multiculturalism: Examining the Politics of Recognition, ed. A. Gutman, Princetor 1994, pp. 25-73. 
The literature which defines the factors that determine the identity of an individual is rich and varied. The development of human identity is perceived as an iterative process in which there is a transaction between a person and context. ${ }^{23}$ In such an operation, there might be a conflict between what a person feels and what is expected from him/ her. People may solve that conflict in a variety of ways, for example, as it is described in the Thomas - Kilmann model, undertaking one of the conflict modes: competing, collaborating, compromising, avoiding, or accommodating. ${ }^{24}$ Summing up, it can be stressed that the identity of an individual is a social construct, the individual shapes his/her identity by recognising his/her social belonging. As Sandra Bem stresses, femininity and masculinity are cultural products; that is why a person is not only an individual who feels his/her identity but also feels as a member of the culture to which he/she belongs. ${ }^{25}$ What is more, in the times of the dominance of free-competitive economy, the consciousness of an individual is influenced by the direct actions of all organizations, which in this way strengthen their market position, and at the same time make the individual dependent on themselves. As Giddens concluded in his famous book: "The more reflexively we 'make ourselves' as persons, the more the very category what a 'person' or 'human being' is comes to the fore."26

23 H.A. Bosma, E.S. Kunnen (2001), Determinants and Mechanisms in Ego Identity Development: A Review and Synthesis, vol. 21 (1), pp. 39$-66$.

24 K.W. Thomas, R.H. Kilmann, Thomas-Kilmann Conflict Mode Instrument. Mountain View, CA: Xicom, a subsidiary of CPP, Inc., 1974.

25 S.L. Bem, Gender schema theory: a cognitive account of sex typing. "Psychological Review" 1981, no. 88, pp. 354-364. Doi:10.1037/0033295X.88.4.354.

26 A. Gddens, Modernity and Self Identity, op.cit., p. 217. 
In the past, identity was related to the fact of being born in here (family, education, nation) and now (an epoch and its culture). Today, in view of the possibility of shaping identity, it is not something given to the individual, but what is built by the individual him - or herself through his/her choices. ${ }^{27}$ Human rights give individuals the right to define and express their own identity.

Bem, in her gender schema theory, has distinguished between four gender identities: sex-typed, cross-sex-typed, androgynous, and undifferentiated. Sex-typed individuals process and integrate information in line with their biological gender. They are seen as differing from other individuals not primarily in terms of how much masculinity or femininity they possess, but in terms of whether their self-concepts and behaviors are organized based on gender. ${ }^{28}$ Cross-sextyped or sex-reversed individuals process and integrate information in line with the opposite gender. Androgynous individuals process and integrate traits and information from both genders regardless of biological sex and undifferentiated individuals do not show efficient processing of sex-typed information regardless of biological sex.

Contemporary philosophical considerations on gender challenge the division of sex into biological and cultural. Judith Butler points to the conventionality and contextuality of the division into women and men. ${ }^{29}$ By questioning the divi-

27 E. Michałkiewicz-Kądziela, Prawo do tożsamości człowieka $w$ prawie polskim $i$ międzynarodowym, Warsaw 2020; J. Kciuba, Idea Ja i koncepcje tożsamości. Zmiana znaczenia idei Ja I koncepcji tożsamości w nauce $i$ kulturze, Lublin 2014.

28 S. Bem, Gender schema theory: A cognitive account of sex typing. "Psychological Review" 1981, no. 88, pp. 354-364.

29 J. Mizielińska, Pteć. Ciało seksualność. Od feminizmu do teorii queer, Kraków 2006, p. 41. 
sion into cultural and biological sex, Butler puts the issue of an individual's identity under a great question. Since my gender has been defined before a person begins to consciously participate in social life, what is their gender identity? Does his or her sense of being a woman, man, gay, and trans person result from the context in which gender has been defined?

Summarizing the considerations on gender identity, the following areas should be indicated: scientific research carried out by various academic disciplines, medical practice, perception and social attitudes towards people with identities different than binary, and legal aspects related to the respect for human rights. The consequences of these four areas which deal with the issue of gender identity are the consequences for LGBT + people as stigma ${ }^{30}$ contributes to people's silence about their own gender identity, which in turn causes the phenomenon of invisibility of these individuals in society. ${ }^{31}$ Asia is an enormous, very diverse continent. It is difficult to find here a platform connecting the peoples inhabiting this large area. What is certain is the fact that regardless of the country or nation, its culture is different from European cultures, including the approach to gender understanding and differentiation. For example, one may find some evidence for gender performativity in Japanese Buddhism and literature, where gender and sex are not perceived as a stable characteristic of a person, but rather a cultural act where gender is liquid and conventional. ${ }^{32}$

30 Stigmatization is understood here in the sense that Erving Goffman still has to do with this social nomenclature. E. Goffman, Stigma. Notes on the Management of Spoiled Identity, New York 1986.

31 K. Bojarska, A. Kłonkowska, Transgresja płci, tranzycja ciała, tranwersja tożsamości. Czym jest transptciowość?, [in:] Psychospołeczne, prawne i medyczne aspekty transptciowości, Gdańsk.

32 K. Górecki, Queerowanie tradycji japońskiego teatru kabuki 


\section{Third gender - definition}

The third gender is a term that describes people perceived by themselves and by their social environment as those who are neither male nor female. These persons perceive themselves as not classified into the biological division of sex. They choose a gender antiregime that refers to desires, preferences and dreams. ${ }^{33}$ People who feel neither like men nor women in the biological understanding of gender, create a subculture integrated with society, which is increasingly often referred as the acronym LGBT + .

As Kuligowski writes, anthropologists have been describing these subcultures as communities that accept different gender identities, which has implications for their lives, cultural norms and behaviours. He lists the following communities where non-heteronormative and non-binary people can be found: Omeggid from Kuna Yala, Mahu in Hawai, Rae-rae in Bora-Bora, Tsekats and Sekrata in Madagascar, Mashoga in East coast of Africa, Calalai and Bakla in Philippines, Kathoey in Thailand, Kinnsr in India, Fa'afafine in Samoa, Muxe in Mexico, Xanith in Oman, alternative gender roles (Two Spirit) in indigenous peoples of North America. ${ }^{34}$

w „Zimnym Płomieniu” Yukio Mishimy, [in:] Cielesność w Azji. Seks, sport, sztuka i śmierć, ed. M. Czubaja, Gdańsk 2016.

33 W. Kuligowski, Trzecia pteć świata, Poznań 2020, p. 11.

34 Other examples of society's recognition of more than two genders can be found elsewhere. For example, the Bugis have five genders: male, female, calabai (individuals who are biological male, but take on a female role), calalai (individuals who are biological female, but take on a male role) and bissu (individuals who embody all four genders at the same time). See: D. Oetomo, Sexual Orientation, and Gender Identity in Southeast Asia, "Asian-Pacific Law \& Policy Journal" 2013, vol. 14:2, p. 123. 
The Trevor Project, which is an organization providing crisis intervention and suicide prevention services to lesbian, gay, bisexual, transgender, queer and questioning (LGBTQ) young people under 25, has prepared the Spectrum which visualizes different gender identities. ${ }^{35}$ They are as follows:

1. Biological sex means what a doctor assigned you at the birth: male, intersex, female.

2. Gender identity means how an individual feels inside: man, gender fluid, trans, woman.

3. Gender expression means how an individual presents himself/herself to others: masculine, androgynous, non-binary, feminine.

4. Gender presentation means how the world sees an individual: man, transgender, genderqueer, non-binary, woman.

5. Sexual orientation means who an individual likes: attracted to women, bisexual, pansexual, asexual, attracted to men.

Thus, in many cultures described by anthropologists, there are gender roles other than exclusively male and female. In the $21^{\text {st }}$ century, global processes, cultural diversity and communication transformation with the special meaning of social media have had a tremendous impact on social consciousness and awareness of gender identity. Nowadays, those who do not identify with male or female roles can express their identity openly in many countries. At the same time, however, such a situation generates obstacles to the improvement of institutions and functional mechanisms

35 https://www.thetrevorproject.org/about/programs-services/ the-spectrum/ [access: 20.04.2021]. 
which might support those persons to feel as they want to. The question arises as to how those who do not accept to be classified as a man or woman are able to participate in the political, economic, social, and cultural life in society. Do they have proper and stable conditions to express their identity and live as they desire to live?

As a result, many of them perform their functions separately; they create their own communities which try to overcome stereotypes, prejudices and many social beliefs to be socially, and sometimes politically, accepted.

\section{Legal status of third sex individuals}

What is an important element of contemporary social practice are legal regulations that can help people who identify as non-binary. The failure to specify the third gender in the documents is a problem for parents of intersex children, who do not want to decide about the identity of their children before they are aware who they want to be, and for non-binary people who do not identify themselves as male or female.

The inability to identify a gender other than male or female is a form of discrimination against people whose identity, and, above all, their sense of identity, is not related to one of the traditional genders. Gradually, more and more countries, in order to protect non-binary people, including intersex people, introduce the possibility of defining their gender as X, which means indeterminate / intersex / unspecified. Australia, Bangladesh, New Zeeland, Canada, Germany, USA, India and some others allow an individual to choose the third option in the official documents. 
The situation of non-binary gender identities is insufficiently legally regulated in most countries. That is because lawmakers must face problems which are controversial due to many reasons, such as cultural diversity, social values' systems, and the fact that they concern the conflicting rights of the individual. ${ }^{36}$ Therefore, the only practical legal solution to any violation of the rights of these people is to respect and refer to the human rights written down in the Universal Declaration of Human Rights, which has already been the world's most translated document, and is now available in more than 500 translations, ${ }^{37}$ and which has been signed by 192 member states of the United Nations.

The source of human rights is liberal thought, which is a product of the culture of Europe and North America. The values of the cultures of Asian countries are based on various religions, paternalism and authoritarianism, which those societies believe are more effective. As a result, the inhabitants of Asian countries differ from European societies in their approach to human rights. However, the processes of globalization and the nature of the Universal Declaration of Human Rights are permeating cultures, having an impact also on the perception and understanding of human rights. ${ }^{38}$

36 K. Gurak, The Rights to Abortion in the Light of the American Constitution Based on the Judgement of Roe v. Wade form 1973 and Development of Judicial Review on This Subject, [in:] Regionalne systemy ochrony praw człowieka $w$ dobie kryzysu demokracji liberalnej, Toruń 2020.

37 https://www.ohchr.org/EN/UDHR/Pages/WorldRecord.aspx [access: 20 .04.2021].

38 R.A. Tokarczyk, Istot $i$ komparatystyka europejskich $i$ azjatyckich uwarunkowań systemów ochrony praw człowieka, [in:] Azjatyckie systemy ochrony praw człowieka. Inspiracja uniwersalna - uwarunkowania kulturowe - bariery realizacyjne, eds. J. Jaskiernia, K. Spryszak, Toruń 2016, p. 18. 
Gender identity has its legal definition formulated in the Yogyakarta Principles in 2006, where it is stated that "gender identity is understood to refer to each person's deeply felt internal and individual experience of gender, which may or may not correspond with the sex assigned at birth, including the personal sense of the body (which may involve, if freely chosen, modification of bodily appearance or function by medical, surgical or other means) and other expressions of gender, including dress, speech and mannerisms." ${ }^{39}$ The Bangkok Declaration ${ }^{40}$ which was adopted to the Universal Declaration of Human Rights in 1993, does not contain a catalog of recognized human rights, and there is no normative resembling the message in its content at all norms. Rather, it is a response to criticism against the process of implementing international human rights standards in Asian countries. In addition to the issue of universality or relativity of human rights, it also touches upon the issue of their historical and geopolitical conditioning and priorities related to their implementation. ${ }^{41}$

Categories of human rights are increasingly known and understood in Asia, despite the lack of any tradition. ${ }^{42}$ However, it should be emphasized that human rights in the culture

39 The Yogyakarta Principles. Principles on the application of international human rights law in relation to sexual orientation and gender identity. Yogyakarta, 2006, p. 6.

40 The Bangkok Declaration is the founding document of Association of Southeast Asian Nations (ASEAN) which was signed in 1967 by 5 founding countries: Indonesia. Malaysia, Philippines, Singapore and Thailand.

41 M. Stępień, Deklaracja Bangkocka - azjatycki głos w sprawie praw człowieka, „ANNALES. Universitatis Mariae Curie-Skłodowska Lublin Polonia" 2010, vol. XVII, no. 1, pp. 23-31.

42 B. Drzewiecka, Interpretacja praw człowieka w Europie i Azji. Konflikt wartości czy wielowartościowa logika? „Studia Prawnoustrojowe" 2008, no. 8, pp. 53-67. 
of Asian countries are understood through the prism of the duties and obligations of an individual towards the community. ${ }^{43}$

\section{Asian communities and their right to accept gender identity}

The inhabitants of Asian countries are strongly associated with the traditions resulting from their religion. For example, South Korea, the culture of which combines Buddhist, Christian and Confucian values, is very traditional on the one hand, i.e., social changes occur very slowly. On the other hand, it has a culture of tolerance of dissimilarity. Hence, people from the LGBT + group may feel safe, but social conservatism sometimes discriminates people them. Revealing homosexuality may require a person to quit his/her job. ${ }^{44}$ A similar situation is in Thailand. Research on Thai sexual and gender minorities suggests that although the Thai society does not prosecute these individuals, it often limits the social space available to them, preventing them from accessing certain services. While knowing the specific needs of gender minorities, it is not ready to accept them completely. ${ }^{45}$ As research disclosed that people of diverse sexual ori-

43 E. Awramik, Cywilizacja kulturowa i religijna różnorodność Azji a ochrona praw człowieka, [in:] Azjatyckie systemy ochrony praw człowieka. Inspiracja uniwersalna - uwarunkowania kulturowe - bariery realizacyjne, eds. J. Jaskiernia, K. Spryszak, Toruń 2016, p. 184.

44 D. Janus, Sytuacja społeczności LGBT w Korei Południowej, [in:] Cielesność w Azji. Seks, sport, sztuka i śmierć, ed. M. Czubaj, Gdańsk 2016.

45 T.T. Ojanen, Sexual/Gender Minorities in Thailand: Identities, Challenges, and Voluntary-Sector Counseling, "Sexuality Research \& Social Policy" 2009, vol. 6, no. 2. 
entations and gender identities are still not fully accepted in the Thai society due to persistent and prevalent prejudices, misconceptions and lack of understanding. ${ }^{46}$ The values of Chinese culture are deeply embedded in Confucian philosophy, which focuses on the patriarchal family, the place of and the individual in society, and the superiority of group interests over the individual. Therefore, the importance of the individual is less important than his/her place in society and his/her relationship with nature. As a result, the full acceptance of human rights built on the liberal foundation arouses controversy not only among the Chinese authorities, but also among the Chinese society. ${ }^{47}$

This approach to traditional Confucian values does not question the possibility and practice of human rights in China or other Asian countries. For example, William Theodore de Bary argues that while the Confucian sense of personhood differs from Western liberal concepts of the individual in some respects, it is not incompatible with human rights, but could, rather, enhance them. ${ }^{48}$ As the Amnesty International report on human rights in Asia - Pacific states, LGBT+ people in China face discrimination and stigma in the society. They are also abused in the form of "conversion therapy". Despite a judgment in 2014, which declared that homosexuality was not a disease and required no treatment, the government did not take any action to ban the conver-

46 B. Suriyasarn, Gender Identity and Sexual Orientation in Thailand, ILO Country Office for Thailand, Cambodia and Lao People's Democratic Republic; Promoting Rights, Diversity and Equality in the World of Work (PRIDE) Project. - Bangkok: ILO, 2014.

47 M. Kamińska (2014), Tradycja chińska a prawa człowieka - wybrane problemy. NURT SVD 1, pp. 243-261.

48 W.T. de Bary, Asian Values and Human Rights. A Confucian Communitarian Perspective, Harvard 2000. 
sion therapy. Transgender people were classed as having a "mental illness", and gender-affirming surgery required the consent of families. ${ }^{49}$

Singapore is a country which, in its legal regulations, declares little respect for human rights. Basic civil rights and freedoms are set out in Part IV of the Constitution, which contains seven articles guaranteeing individual freedoms such as the freedom of moving, choosing a place of residence, freedom of speech and expression, freedom of conscience and religion, ${ }^{50}$ although one cannot find fundamental - from western regulations - guarantees such as voting rights, property rights and the prohibition of torture. Moreover, the state still has the death penalty. ${ }^{51}$

Article 15 of the Indian Constitution states: "(1) The State shall not discriminate against its citizens by religion, race, caste, gender, place of birth, or any other cause. (2) No citizen - by religion, caste, race, gender, place of birth or for any other reason - may not be discriminated against or limited in: (a) access to shops, restaurants, hotels and other public places; or (b) use of manholes, reservoirs, bathing areas, roads and maintained public utilities wholly or partly from the state budget or intended for public use". Transgender has a strong historical background in India. It is known from the ancient scriptures of Veda, Puranic literature like Ramayana and Mahabharata and it comprises of Hijras, Kothis, Aravanis,

49 Human Rights in Asia-Pacific: Review of 2019, Amnesty International, 2020.

50 M. Ochwat, Systemy konstytucyjne Tajlandii, Malezji i Singapuru, Warszawa 2016, p. 31.

51 A. Michalak, Przestrzeganie praw człowieka $w$ wybranych państwach Azji postkolonialnej - aktualne problemy. „Przegląd Prawa Konstytucyjnego" 2015, no. 1 (15), pp. 115-134. 
Jogappas, Shiv-Shakthis, etc. ${ }^{52}$ In India, in December 2019, during the winter session of the Parliament, the Transgender Persons (Protection of Rights) Act was passed. The Act refers to a transgender person as the one whose gender does not match the gender assigned at birth. It includes trans-men and trans-women persons with intersex variations, gender-queers, and persons with socio-cultural identities, such as kinnar and hijra. The act undermines the rights of transgender and intersex persons and violates India's international human rights obligations. ${ }^{53}$ The Act requires a transgender person to go through a district magistrate and district screening committee to get certified as a trans-person. ${ }^{54}$

The Malaysian constitution also guarantees basic freedoms such as personal freedom, freedom from slavery and forced labor, freedom of religion, right to property, freedom of expression, and freedom of assembly. However, the practice of these rights may be restricted if only the parliament considers it necessary. ${ }^{55}$ As the Amnesty International report stresses, discrimination against LGBTI people in 2019 continued both in law and in practice. ${ }^{56}$

In Japan, in December 2018, four opposition parties introduced a bill to ban the discrimination against LGBT people.

52 G.K. Bansal, S. John, Making Trans-Gender Healthcare a Priority in India. Journey towards Social Inclusion, "Indian Journal of Community Health" 2020, no. 32 (2), pp. 324-329.

53 Human Rights in Asia-Pacific: Review of 2019, Amnesty International, 2020, p. 22

54 G.K. Bansal, S. John, Making Trans-Gender Healthcare a Priority in India. Journey towards Social Inclusion, op.cit., p. 327.

55 M. Ochwat, Systemy konstytucyjne Tajlandii, Malezji i Singapuru, op.cit., p. 32.

56 Human Rights in Asia-Pacific: Review of 2019, Amnesty International, 2020, p. 34. 
In September, the Tokyo Metropolitan Government introduced a basic plan on Sexual Orientation and Gender Identity (SOGI) to implement the ordinance adopted in October 2018, which banned discrimination against LGBT people. While individuals have been allowed to officially change their sex under the Act on Gender Identity Disorder, the recognition requirements, such as being deprived of their reproductive organs or reproductive ability, gender confirmation surgery and single status, violate their human rights. ${ }^{57}$

In Taiwan, despite the achievement in enhancing the protection of LGBTI rights (on 17 May the Legislative Yuan passed The Enforcement Act of the Judicial Yuan Interpretation No.748, legalizing same-sex marriage), there is more to be done to improve awareness of the need for antidiscrimination in the society, especially in schools. Homophobia, distorted views on LGBTI people and bias still exist in some parts of the society and the education system. ${ }^{58}$ In Southeast Asia, there is a long and rich tradition of sexual diversity. For example, in Indonesia, Burma, and the Philippines, one may find traditions very similar to the male-to female transgender fa'afafine in Samoa and fakaleiti in Tonga. ${ }^{59}$

Summing up, it is necessary to emphasize the existing cultural dissonance when it comes to the rights of people who declare themselves to be the representatives of the third gender in Asian countries. In many Asian societies, a non-binary gender tradition (third gender) is long, well known and portrayed. However, legal regulations to an insignificant extent consider the right of an individual to freely

57 Ibidem, p. 28.

58 Ibidem, p. 60.

59 D. Oetomo, Sexual Orientation, and Gender Identity in Southeast Asia, "Asian-Pacific Law \& Policy Journal" 2013, vol. 14 (2), pp. 118-131. 
express his/her gender identity. The third gender in Asia, as well as in other countries in the world, is a fact; people who do not feel neither a man nor a woman, are not imaginary. They are alive, they are real, they have their own human needs and desires. They were known to our ancestors. And today, in so many countries, they face a lack of recognition and acceptance.

In view of the internalized schema of the two genders, non-binary, non-heteronormative people are invisible because they are aware of how difficult it is to break this traditional, cultural, social patterns and norms.

\section{Summary}

The current legal and institutional solutions do not guarantee full protection for the third gender. In many of the Asian countries, their rights do not exist at all or are consciously ignored. As a result, non-binary individuals may feel social stigma or/and social isolation. The issue of gender identity is very poorly covered by law. The research and analyses of their situations, positions, problems and difficulties are made only by non-governmental organizations or institutions related to the UN.

The lack of activity monitoring and analyzing the issues of gender identity not only causes the lack of appropriate regulations, but also contributes to their lack of visibility in society, which in turn leads to low awareness of the existence of people other than male and female.

The article highlights issues related to the implementation of human rights regarding the acceptance and affirmation of genders other than binary. The identity of an 
individual does not only mean what he or she feels like, but also what he/she is for himself/herself and for his/her social groups. It is the need to be oneself and the need to be socially recognized and accepted. The 21st century creates significant opportunities for third-gender people to get to know and claim their human rights. However, the situation in many Asian countries shows how far the road to full recognition is. Despite some cultural traditions and the absence of religious prohibitions, non-binary people still struggle to recognize their identity.

\section{Bibliography}

Awramik E. Cywilizacja kulturowa i religijna różnorodność Azji a ochrona praw człowieka, [in:] Azjatyckie systemy ochrony praw człowieka. Inspiracja uniwersalna - uwarunkowania kulturowe - bariery realizacyjne, eds J. Jaskiernia, K. Spryszak, Toruń 2016.

Bansal G.K., John S., Making Trans-Gender Healthcare a Priority in India. Journey towards Social Inclusion, "Indian Journal of Community Health" 2020, no. 32 (2). de Bary W.T., Asian Values and Human Rights. A Confucian Communitarian Perspective, Harvard 2000.

Bem S.L. (1981), Gender schema theory: A cognitive account of sex typing, "Psychological Review" 1981, 88 (4), https://doi.org/10.1037/0033-295X.88.4.354.

Bojarska K., Kłonkowska A., Transgresja ptci, tranzycja ciata, tranwersja tożsamości. Czym jest transptciowość?, [in:] Psychospołeczne, prawne i medyczne aspekty transptciowości, Gdańsk 2014.

Bosma H.A., Kunnen E.S., Determinants and Mechanisms in 
Ego Identity Development: A Review and Synthesis, 2001, Vol. 21 (1).

Boudreau M., Serrano Ch., Larson K., IT-driven identity work: Creating a group identity in Digital environment. "Information and Organization" 2014, no. 24.

Butler J., Zapiski o performatywnej teorii zgromadzeń, Warsaw 2016.

Castells M., Siła tożsamości, Warsaw 2008.

Drzewiecka B., Interpretacja praw człowieka w Europie i Azji. Konflikt wartości czy wielowartościowa logika? „Studia Prawnoustrojowe” 2008, no. 8.

Erikson E.H., Tożsamość a cykl życia. Warsaw 2004.

Erikson E.H., Dzieciństwo i społeczeństwo, Poznań 2000.

Giddens A., Modernity and Self-Identity. Self and Society in the Late Modern Age, Cambridge 1991.

Glaveanu V.P., Tanggaard L., Creativity, identity, and representation: Towards a socio-cultural theory of creative identity, "New Ideas in Psychology" 2014, no. 34.

Goffman E., Stigma. Notes on the Management of Spoiled Identity, New York 1986.

Górecki K., Queerowanie tradycji japońskiego teatru kabuki $w$ „Zimnym Ptomieniu” Yukio Mishimy, [in:] Cielesność w Azji. Seks, sport, sztuka i śmierć, ed. M. Czubaj, Gdańsk 2016.

Gurak K., The Rights to Abortion in the Light of the American Constitution Based on the Judgement of Roe v. Wade form 1973 and Development of Judicial Review on This Subject, [in:] Regionalne systemy ochrony praw człowieka w dobie kryzysu demokracji liberalnej, Torun 2020.

Human Rights in Asia-Pacific: Review of 2019, Amnesty International, 2020.

Janus D., Sytuacja społeczności LGBT w Korei Południowej, 
[in:] Cielesność w Azji. Seks, sport, sztuka i śmierć, ed. M. Czubaja, Gdańsk 2016.

Kamińska M., Tradycja chińska a prawa człowieka - wybrane problemy, NURT SVD 1, 2014.

Kciuba J., Idea Ja i koncepcje tożsamości. Zmiana znaczenia idei Ja I koncepcji tożsamości w nauce i kulturze, Lublin 2014.

Klosow M., Gender Bending. Praktyki przekraczania kulturowych norm ptci, Warsaw 2019.

Kuligowski W., Trzecia pteć świata, Poznań 2020.

Michalak A., Przestrzeganie praw człowieka $w$ wybranych państwach Azji postkolonialnej - aktualne problemy. „Przegląd Prawa Konstytucyjnego” 2015, no. 1 (15).

Michałkiewicz-Kądziela E., Prawo do tożsamości człowieka w prawie polskim i międzynarodowym, Warszawa 2020. Mizielińska J., Pteć. Ciało seksualność. Od feminizmu do teorii queer, Kraków 2006.

Ochwat M., Systemy konstytucyjne Tajlandii, Malezji i Singapuru, Warsaw 2016.

Oetomo D. (2013), Sexual Orientation, and Gender Identity in Southeast Asia, "Asian-Pacific Law \& Policy Journal", vol. 14:2.

Ojanen T.T., Sexual/Gender Minorities in Thailand: Identities, Challenges, and Voluntary - Sector Counseling, "Sexuality Research \& Social Policy" 2009, vol. 6, no. 2.

Paleczny T., Socjologia tożsamości, Kraków 2008.

Rawa-Kochanowska A., Poczucie tożsamości ptciowej w teorii i badaniach, Warsaw 2011.

Stoet G., Geary D.C., A simplified approach to measuring national gender inequality, PLoS ONE 14 (1): e0205349, 2019, https://doi.org/10.1371/journal.pone.0205349.

Suriyasarn B., Gender Identity and Sexual Orientation in 
Thailand, ILO Country Office for Thailand, Cambodia and Lao People's Democratic Republic; Promoting Rights, Diversity and Equality in the World of Work (PRIDE) Project. - Bangkok: ILO, 2014.

Świątkiewicz-Mośny M., Konstruowanie nowych tożsamości w warunkach globalizacji, Kraków 2015.

Tajfel H., Social identity and intergroup behaviour, "Social Science Information" 1974, vol. 13 (2), doi: 10.1177/0539 01847401300204.

Tajfel H., Tożsamość społeczna i zachowanie międzygrupowe. „Przegląd Psychologiczny” 1976, vol. XIX, no. 2.

Thomas K.W., Kilmann R.H., Thomas-Kilmann Conflict Mode Instrument, Mountain View, CA: Xicom, a subsidiary of CPP, Inc., 1974.

Tokarczyk R.A. (2016), Istot i komparatystyka europejskich i azjatyckich uwarunkowań systemów ochrony praw cztowieka, [In:] Azjatyckie systemy ochrony praw człowieka. Inspiracja uniwersalna - uwarunkowania kulturowe bariery realizacyjne, eds J. Jaskiernia, K. Spryszak, Toruń 2016.

Tylor Ch. (1994), The Politics of Recognition, [in:] Multiculturalism: Examining the Politics of Recognition, ed. A. Gutman, Princeton 1994.

Tylor Ch. (1995), Źródta wspótczesnej tożsamości, [in:] Tożsamość w czasach zmiany. Rozmowy w Castel Gandolfo, Kraków 1995.

Waterman A.S., Identity, the Identity Statuses, and Identity Status Development: A Contemporary Statement, "Developmental Review" 1999, no. 19.

Ziemińska R., Niebinarne i wielowarstwowe pojęcie ptci. Próba inkluzji danych o osobach interptciowych $i$ niebinarnych, Warsaw 2014. 


\section{Antonio Stango}

Link Campus University, Rome, Italy

ORCID ID: https://orcid.org/0000-0001-7137-4497

\section{Freedom of Religion and Minority Rights in China}

\section{Introduction}

While it would evidently be out of the scope of this article to analyze all the complex aspects of the relations among the state, the dominant ethnic group and minorities in a country with a population of about $1,400,000,000$, we can try and outline some of the most relevant implications of this issue regarding their impact on human rights. What appears particularly important, however, is the close interrelation of some ethnic groups with the religion traditionally professed by the vast majority of their members, as this in many cases has been documented as the ground for the strict limitations of religious freedom, up to amounting to the massive and violent oppression of millions of people.

\section{6 'nationalities' or ethnic groups - with no rights to self-determination}

Officially, the People's Republic of China comprises fifty-six 'nationalities' (55 minorities plus the dominant Han), which in most cases may be properly defined as ethnic groups. This requires a preliminary consideration. 
The term 'nationality' ("natsionalnost" in Russian, "minzu" in Mandarin) was actually used in Soviet Union to define ethnic groups, while the citizenship was 'Soviet'; the same concept is nowadays in use in several former Soviet states, such as in Kazakhstan - where the citizenship is 'Kazakhstani', while the 'nationality' can be Kazakh, Russian, Chechen or one of the many other ethnicities which compose the population of that country. The PRC adopted a similar system. However, as history showed, some of the 'nationalities' of Soviet Union had all the requisites and aspirations to achieve a full sovereign statehood, which in many cases happened, while other ethnic groups have since been struggling to achieve that goal. Avoiding, by any means, a similar outcome is the constant objective of the Chinese Communist Party (CCP), which has about 86.5 million members and strictly controls the whole state's structure at any level.

As a matter of fact, "the principles for exercising power written in the constitution of the PRC are merely a facade, and in reality all state institutions are under the full control of the CCP. [...] The principle of the unity of state power (the absence of separation of powers) means that the formal source of all power, including executive and judiciary, is the people, as personified in the National People's Congress." ${ }^{\text {. }}$

The same principle of "unity" guides the efforts by the CCP when it comes to the issue of 'minority nationalities' (xiaoshu minzu), to whom certain rights and even limited privileges can be assigned only under the condition that self-identification as an ethnic group will not lead to any

1 M. Bogusz, J. Jakóbowski, The Chinese Communist Party and its State - Xi Jinpings' Conservative Turn, Warsaw, 2020, p. 39, https://www. osw.waw.pl/sites/default/files/REPORT_The-Chinese-Communist-Party_net.pdf 
separatism. Fighting "separatism" is also one of the main goals of the Shanghai Cooperation Organisation (SCO), which entered into force in September 2003 and include, among else, a "Regional Anti-Terrorist Structure" (RATS) based in Tashkent. ${ }^{2}$ The wide definition of "separatism" and its substantial assimilation to "terrorism" are instrumental for the policy of tough control of the ethnic minorities adopted by the CCP.

Having regard to this, we can summarize some statistical data about the ethnic groups in China. The largest ethnic group, Han, constitutes about $91 \%$ of the total population, but actually their number "comprises a wide variety of culturally and ethnically diverse populations, including eight mutually unintelligible linguistic groupings (Mandarin, Wu, Yue, Xiang, Hakka, Gan, Southern Min, and Northern Min).”3

Some of the largest minorities live in China's border regions.

According to UNICEF, whose figures are based on the PRC's National Bureau of Statistics,

In 2015, the total population of the ethnic minority groups was 117 million, accounting for 8.5 per cent of the total population and mostly residing in western China. Four ethnic minority groups had a population over

2 The SCO comprises eight member states (the Republic of India, the Republic of Kazakhstan, the People's Republic of China, the Kyrgyz Republic, the Islamic Republic of Pakistan, the Russian Federation, the Republic of Tajikistan, and the Republic of Uzbekistan), as well as four observer states (the Islamic Republic of Afghanistan, the Republic of Belarus, the Islamic Republic of Iran and the Republic of Mongolia), and six dialogue partners (the Republic of Azerbaijan, the Republic of Armenia, the Kingdom of Cambodia, the Federal Democratic Republic of Nepal, the Republic of Turkey, and the Democratic Socialist Republic of Sri Lanka): http://eng.sectsco.org/about_sco/ [access: 1.02.2021].

3 D.C. Gladney, Dislocating China - Reflections on Muslims, Minorities, and Other Subaltern Subjects, London 2004, pp. 8-9. 
10 million, namely Zhuang, Hui, Uyghur and Manchu. Among all provinces in 2015, the population of Tibet had the highest proportion of ethnic minorities (95 per cent), while Guangxi was home to 18 million people of ethnic minority status, who were mainly Zhuang. The next largest ethnic groups include Zhuang (18 million), Manchu (15 million), Hui (10 million), Miao (9 million), Uyghur (8 million), Yi (7.8 million), Tujia (8 million), Mongols (5.8 million), Tibetans (5.4 million), Buyei (3 million), Yao (3.1 million), and Koreans ( 2.5 million). ${ }^{4}$

The statistics about the numbers of these populations are not unanimously considered fully reliable, as in several cases the authorities tend to pretend either that there are more people in order to show that they are well treated, or - on the contrary - that there are fewer, in order to argue that their case is not relevant. As for one of the most delicate issues, I would accept that there are "about 11 million Uighurs living in the Xinjiang region of Western China, and between one million and three million of them have been detained in camps since 2017, according to American government and human rights group estimates."

As far as the language is concerned, which is one of the bases for identification of minorities, while Huis and Manchus (who have largely been assimilated) speak Mandarin and write Chinese characters like the Han, among the other minorities about 120 languages are spoken - i. e. more than

4 https://www.unicef.cn/en/figure-14-percentage-ethnic-minority-groups-province-2015\#: :text=China\%20is\%20comprised\%20of\%20 56,mostly\%20residing\%20in\%20western\%20China [access: 1.02.2021].

5 Fifield A., China celebrates 'very happy lives' in Xinjiang, after detaining 1 million Uighurs, "The Washington Post", 30.07.2019: https://www.washingtonpost.com/world/china-celebratesvery-happy-lives-in-xinjiang-after-detaining-a-million-uighurs/2019/07/30/0e07b12a-b280-11e9-acc8-1d847bacca73_story.html. 
the double than the recognized minority groups. Those languages belong to a variety of linguistic families, including, among else, Sino-Tibetan (Mandarin, Tibetan, KamTai, Miao-Yao), Turkic-Altaic (Kazakh, Uyghur, Mongolian, Manchu-Tungus, Korean), Austro-Asiatic (Hmong, Vietnamese). There are also differences among writing systems, even within people who speak the same language.

Although Mandarin is the official national language, all languages are theoretically equal by law. According to the 2001 Bill of Autonomous Regions of Ethnic Peoples, ethnic Han leaders are required to learn the language of the ethnic people among whom they work, and bonuses are given to those who can speak more than two ethnic languages. However, more than 60 of those languages are spoken only by a few thousand people each, and some of them are considered at imminent risk of extinction. ${ }^{6}$

A Tibetan historian, currently at British Columbia University, observed a "decline in the use of the Tibetan language", as, while "in the 1980s, the Chinese Communist Party leaders encouraged the Tibet Autonomous Region (TAR) to develop local laws to protect itself from outside pressure, such as laws requiring Tibetan to be the language of administration in the region", nowadays the "sheer speed and force of economic change is making any talk of autonomy redundant. In most urban areas of TAR, Tibetans cannot function without the knowledge of Mandarin, which is required for education and employment."

6 Yuan Haiwang, Chinese Ethnicities and Their Culture: An Overview, 2008, http://digitalcommons.wku.edu/dlps_fac_pub/23 [access: 1.02.2021].

7 Tsering Shakya, Beyond development and diversity (interview), "Himal Southasian", 25.06.2018, https://www.himalmag.com/beyond-development-and-diversity-historian-tsering-shakya-interview/ [access: 1.02.2021]. 
There are five officially autonomous regions and 151 ethnic minority autonomous areas (including 30 prefectures and 121 counties); but the actual degree of autonomy is very limited. On the one hand, there is a multiculturalist rhetoric, which can include some "affirmative action incentives (e.g., allocating extra points on college entrance exam to assigning a percentage of regional governmental positions to minorities)"; on the other hand, there is a constant effort to "undermine minority nationalism". Therefore, while soft policies aim to "undermine the creation of a united ethnic front", hard policies [...] are used to clamp down on elements believed to be fostering dissent, advocating independence, or carrying out terrorist attacks. ${ }^{8}$

At the same time, taking advantage of some economic opportunities arising with the new development policies from the late 1980s, a great number of Hans entered into every autonomous region, even without official government permission, settling "in Tibet, Inner Mongolia, Yunnan, and Xinjiang's newer industrial cities and transportation centers. The state's officials refused to prevent this illegal influx as it is regarded as beneficial to China's long-term goal of integrating its autonomous regions into China proper."

In Inner Mongolia - as the PRC officially calls what for Mongolian history used to be "Southern Mongolia" - the Mongolian language and culture are reportedly facing risks of eradication. As in September 2020 Mongolian became only a secondary language of education after Mandarin in several matters in elementary and middle schools of the re-

8 J. Rudelson, W. Jankowiak, Acculturation and Resistance: Xinjiang Identities in Flux, [in:] Xinjiang: China's Muslim Borderland, ed. F.S. Starr, London-New York 2015 (1 $1^{\text {st }}$ ed. New York 2004), p. 301.

9 Ibidem. 
gion, brave protests, especially from students, took place in several cities - the authorities responded with arrests and the intensification of controls. ${ }^{10}$ The sinicization of the region has included, among else, massive Han migration and the relocation of pastoral Mongols from the prairies into new housing complexes in towns, and "ethnic Mongolians have become a minority in their own land, accounting for only about $17 \%$ of Inner Mongolia's population of 24 million." 11

\section{Recognized religions, unregistered cults, and one dominant 'religion': the party-state}

Article 36 of the Chinese constitution says that citizens "enjoy freedom of religious belief." The Chinese Communist Party is officially atheist, but it recognizes five religions, which are usually listed in order of the date of their presence on the territory of the current People's Republic of China: Buddhism, Catholicism, Taoism, Islam, and Protestantism. However, not only many unregistered or banned religious groups, but also leaders and believers of the five recognized ones are often strictly monitored, and in some cases hardly discriminated and persecuted. In the last two decades, the number of religious believers has anyway been reported

10 Introvigne M., Inner Mongolia Protests Against Cultural Genocide Gain Momentum, "Bitter Winter", 9.01.2020, https://bitterwinter.org/inner-mongolia-protests-against-cultural-genocide-gain-momentum/ [access: 26.02.2021].

11 Jianli Yang, Lianchao Han, China's war against the Mongolian language, "The Washington Times", 29.09.2020, https://www.washingtontimes.com/news/2020/sep/29/chinas-war-against-the-mongolianlanguage/ [access: 26.02.2021]. 
growing, challenging both the repression and the pressures to adhere to the party ideology.

It has been proven very difficult for scholars to get fully reliable data on the numbers of believers in China, NGOs, or governments. Even the China Internet Information Center, a state-run web portal published under the auspices of the State Council Information Office and part of the China International Publishing Group, whose editor-in-chief is a vice minister of the Publicity Department of the CCP, admits that statistics concerning this issue are "incomplete". According to this source, "there are over 100 million followers of various religious faiths, more than 85,000 sites for religious activities, some 300,000 clergy and over 3,000 religious organizations throughout China." It also mentions "13,000-some Buddhist temples and about 200,000 Buddhist monks and nuns", "over 1,500 Taoist temples and more than 25,000 Taoist priests and nuns", "18 million, whose faith is Islam", "four million Catholics", and "about 10 million Protestants."12

However, a 2017 Freedom House special report "focuses on seven communities that together account for over 350 million believers: the country's officially recognized religions - Buddhism (Chinese and Tibetan), Taoism, Catholicism, Protestantism, and Islam - as well as Falun Gong, the largest of several banned qigong practices, new religious movements, and quasi-Christian sects." ${ }^{13}$ Buddhist practitioners are estimated to be $185-250$ million.

12 China Internet Information Center, http://www.china.org.cn/ewhite/Freedom/f-1.htm [access: 15.02.2021].

13 Cook S., The Battle for China's Spirit - Religious Revival, Repression, and Resistance under Xi Jinping, 2017: https://freedomhouse.org/ report/special-report/2017/battle-chinas-spirit [access: 10.12.2020]. 
Undergoing the difficult task of comparing different statistics, and trying to balance the respective figures, one can argue that about $75 \%$ of the population of China is supposed to have no religious faith, or to have some folk traditional creeds; which is consistent with the Freedom House figure of about 350 million religious believers.

The official propaganda machine constantly aims to explain how religions should be working for "the country", i.e. for the political and social agenda of the CCP. After a reference to the need to correct "the errors" committed during the "cultural revolution" of 1966-1976 ("errors" which I would define crimes against humanity, if not acts of genocide $\left.^{14}\right)$, the China Internet Information Center writes:

In the course of the country's long history, the various religions in China have become part of the traditional Chinese thinking and culture. It is traditional for Chinese religious believers to love their country and religions. The Chinese government supports and encourages the religious circles to unite the religious believers to actively participate in the construction of the country. The various religions all advocate serving the society and promoting people's well-being, such as the Buddhists' "honoring

14 "The widespread phenomenon of mass killings in the Cultural Revolution consisted of five types: 1) mass terror or mass dictatorship encouraged by the government - victims were humiliated and then killed by mobs or forced to commit suicide on streets or other public places; 2) direct killing of unarmed civilians by armed forces; 3 ) pogroms against traditional "class enemies" by government-led perpetrators such as local security officers, militias and mass; 4) killings as part of political witchhunts (a huge number of suspects of alleged conspiratorial groups were tortured to death during investigations); and 5) summary execution of captives, that is, disarmed prisoners from factional armed conflicts." In Song Yongyi, Chronology of Mass Killings during the Chinese Cultural Revolution (1966-1976): https://www.sciencespo.fr/mass-violence-war-massacre-resistance/en/document/chronology-mass-killings-during-chinese-cultural-revolution-1966-1976.html [access: 15.02.2021]. 
the country and benefiting the people," the Catholics and Protestants' "glorifying God and benefiting the people," the Taoists' "being benevolent, peaceful and harmonious, saving the world and benefiting the people," and the Islam's "praying to Allah to give great reward in this world and hereafter." 15

In order to enforce such a wishful vision of all religions cooperating for "the construction of the country", the CCP established and controls several national religious organizations: Buddhist Association of China, Taoist Association of China, Islamic Association of China, Chinese Patriotic Catholic Association, Chinese Catholic Bishops' College, Three-Self Patriotic Movement Committee of the Protestant Churches of China, and China Christian Council. They are supposed to "run their own affairs independently and set up religious schools, publish religious classics and periodicals, and run social services according to their own needs", while all "normal clerical activities conducted by the clergy and all normal religious activities held either at sites for religious activities or in believers' own homes in accordance with usual religious practices" are theoretically protected by law. The law, however, fails to clearly define what would be considered "normal" by the state's (meaning CCP's) bodies, thus leaving wide possibilities for repression whenever authorities would deem it appropriate. ${ }^{16}$

According to Freedom House, "religious groups have been swept up in a broader tightening of CCP control over civil society and an increasingly anti-Western ideological bent under [Chinese President] Xi Jinping."17

15 http://www.china.org.cn/e-white/Freedom/f-1.htm [access: 15.02.2021].

16 Ibidem.

17 S. Cook, The Battle for China's Spirit - Religious Revival, Repres- 
Reports by the Pew Research Center show that in each of the 10 years from 2007 to 2016,

China has been near the top of the list of most restrictive governments. In 2016, the most recent year for which the Center has religious restrictions data, the Chinese government was the most restrictive toward religious groups among all the 198 countries included in the study [...]. The Chinese government restricts religion in a variety of ways, including by banning entire religious groups and detaining their members. For example, the government has legally banned the Falun Gong movement, as well as several Christian groups. At the end of 2017, over 3,000 Falun Gong practitioners remained in state detention, with some reported deaths in prison. In addition, hundreds of members of other groups, including Protestants, Muslims, Buddhists and Catholics, remained imprisoned at year's end. ${ }^{18}$

On the other hand, in the last few years Xi has tended to tolerate and somehow promote traditional beliefs or cultures, including first of all Confucianism, as long as the CCP deem them consistent with the party's policies.

\section{The case of Tibetan Buddhism}

Only about six million ethnic Tibetans currently live in the vast territory (around 2.5 million square kilometers, at an average altitude of 5,000 meters) that once constituted the

sion, and Resistance under Xi Jinping, 2017: https://freedomhouse.org/ report/special-report/2017/battle-chinas-spirit [access: 10.12.2020].

18 S. Majumdar, Recent Chinese dealings with faith groups reflect a pattern of government restrictions on religion, 11.10.2018: https://www. pewresearch.org/fact-tank/2018/10/11/recent-chinese-dealings-withfaith-groups-reflect-a-pattern-of-government-restrictions-on-religion/ [access: 1.02.2021]. 
independent state of their ancestors. As political and religious authority have been for centuries strictly intertwined in Tibet, the attitude of the CCP towards Tibetan Buddhists is particularly hard, often amounting to religious-ethnic persecution.

Having been an independent kingdom from the $14^{\text {th }}$ to the $18^{\text {th }}$ century, with strong connections especially with the Mongol khans, and from 1720 under the rule of Chinese Qing empire, Tibet enjoyed de facto independence from 1912 to 1950. Then, the Chinese People's Liberation Army occupied Eastern Tibet, and completed the annexation of Central Tibet in 1951. A "Seventeen-Point Agreement", signed in Beijing in 1951, established the sovereignty of the PRC over officially autonomous Tibet, while the existing political system of Tibet - including, among others, the status and power in the region of the Dalai Lama (traditionally the spiritual and temporal leader) - did not have to be changed.

However, discontent among the population and efforts to regain independence brought several uprisings: the main one took place in 1959 in the capital Lhasa and was bloodily suppressed by Chinese troops, leaving tens of thousands people dead. The current, $14^{\text {th }}$ the Dalai Lama, Tenzin Gyatso, who was then 23 years old, fled to India, where he was granted political asylum and established a government in exile in Dharamshala, later on reached by about 80,000 fellow Tibetans who settled there. The Tibetan local government was liquidated and the CCP took the full command of the territory, most of which in 1965 was defined as Tibetan Autonomous Region (TAR), while some Eastern Tibetan lands were incorporated into neighboring Chinese provinces.

The "Cultural Revolution", started under Mao Zedong in 1966, was extremely hard in Tibet, involving a even higher 
degree of repression of Tibetan culture and religion and the destruction of hundred of monasteries and temples:

When it ended with Mao's death in September 1976, more than 6,000 monasteries and religious institutions in Tibet laid in ruins. Millions of ancient and priceless manuscripts were burnt. Statues made of gold, silver, or bronze were removed from the temples and shipped to China. The physical torture and psychological traumas endured by Tibetans during public "struggle sessions" and imprisonment were beyond human comprehension. At least 92,000 Tibetans who were subjected to "struggle sessions" died or committed suicide and around 173,000 Tibetans died in prison, or in "Reform Through Labor Camps" (Laogai). ${ }^{19}$

Under the leadership of Deng Xiaoping, some more religious and cultural rights for Tibetans were allowed, by no way implying any political autonomy. While some monasteries were reconstructed, intrusive controls led to hundreds of demonstrations and new repressions.

In June 1988, the Dalai Lama declared that Tibet was not anymore aiming to independence, but "should become a self-governing, democratic political entity [...] in association with the People's Republic of China" ${ }^{20}$ However, the Chinese regime rejected his offer and protests and riots continued to occur. Martial law was declared in March 1989 and was enforced until May 1990, while the Dalai Lama was awarded the Nobel Peace Prize 1989 "for advocating peace-

19 Tashi Phuntsok, Revisiting the "Cultural Revolution" in Tibet, 31.10.216, https://tibet.net/revisiting-the-cultural-revolution-in-tibet/ [access: 1.02.2021].

20 Mann J., Dalai Lama Shifts Stand on Tibet Independence, "Los Angeles Times", 16.06.1988, https://www.latimes.com/archives/la-xpm1988-06-16-mn-6860-story.html. 
ful solutions based upon tolerance and mutual respect in order to preserve the historical and cultural heritage of his people."21

On that occasion, the Dalai Lama presented a plan - rejected by the Chinese government - "for the restoration of peace and human rights in Tibet" and "recommended that the country be turned into an ecologically stable and demilitarized zone that might serve as a buffer between major Asian powers."22 By contrast, in June of that same year, 1989, the massacre of Beijing Tiananmen square took place, with a death toll estimated up to several thousand people. It put an end to any hope of freedom of the expression and association in China and has since been strictly censored by the Chinese regime.

In 1994, an official "Third Work Forum on Tibet" defined the Dalai Lama as an enemy, starting a widespread campaign of vilification of him.

That forum had announced a strategy of stimulating the Tibetan economy through large-scale investment and subsidies, as a follow-up to the more-or-less forced introduction of rapid marketization [...]. For no compelling reason, the forum had also called for the public denunciation of the exiled Tibetan leader, the Dalai Lama, in his religious capacity and in personal terms. Such a move was unprecedented for the Chinese authorities in the postCultural Revolution era. It was probably the single most important factor in the increase in protest, nationalism and unrest among Tibetans that took place over the following decade and a half and bans on possessing his image or worshipping him were soon reported, though their

21 The Nobel Prize, https://www.nobelprize.org/prizes/peace/1989/ lama/facts/ [access: 15.02.2021].

22 Ibidem. 
legal basis remains unclear and implementation has been uneven. Over the following years, the party's United Front Work Department (UFWD) launched campaigns of patriotic reeducation in monasteries. These coercive study sessions routinely include requirements that monks and nuns denounce the Dalai Lama verbally and in writing. ${ }^{23}$

While the authorities ordered to remove and destroy the once ubiquitous portraits of the Dalai Lama even from private homes, often replacing them with photos of party's officials, many monks and nuns have been detained and reportedly tortured for refusing to denounce their spiritual leader.

Meanwhile, the rapid economic development program brought in the region tens of thousands non-Tibetans, who currently constitute more than 10 per cent of the population.

A big wave of protests began in Lhasa on March 10, 2008 to mark the anniversary of the 1959 uprising and extended to other Tibetan provinces. The authorities reacted with violence, opening fire on protesters, and killing tens of them. Many cases of self-immolations of Tibetan men and women were reported next year, and a total of 155 (of whom 133 died) from 2009 to $2019 .{ }^{24}$

Since then, the government has implemented hammering political education campaigns, strictly monitored with security personnel (and recently also with facial-recognition cameras) monasteries and religious ceremonies, restricted

23 R. Barnett, Restrictions and Their Anomalies: The Third Forum and the Regulation of Religion in Tibet, "Journal of Current Chinese Affairs", 1.12.2012, https://journals.sagepub.com/doi/10.1177/186810261204100403 [access: 10.12.2020].

24 Source: Central Tibetan Administration (in exile), https://tibet.net/important-issues/factsheet-immolation-2011-2012/ [access: 23.02.2021]. 
travels for ethnic Tibetans, limited visits to pilgrimage sites, and detained and tortured a number of nonviolent protesters or dissidents. New measures include also - as in other contests - internet and mobile phone monitoring, localized blackouts, and surveillance with drones.

What was a particularly astonishing measure intended to control religious leadership, in a way that many observers could not better define than absurd, was the decision by the atheist $\mathrm{CCP}$ to have the last say about the reincarnation of lamas. "In 2007, the State Administration for Religious Affairs (SARA) issued a document called 'Measures on the Management of the Reincarnation of Living Buddhas', asserting that state approval was required for reincarnations. In January 2016, authorities launched a new online database of officially approved reincarnated lamas (tulkus), which notably excluded the Dalai Lama." ${ }^{25}$

The CCP did not dare to choose a new the Dalai Lama as an alternative to the current one, but it made clear that it would select his successor by deciding about his reincarnation; notwithstanding the fact that the Dalai Lama himself had suggested several times that "he might choose his successor before he dies, deviating from the practice of senior lamas' identifying each the Dalai Lama's reincarnation after his death." ${ }^{26}$

In 2011, speaking in Dharamshala on March 10 - the anniversary of the 1959 Tibetan uprising against Chinese rule and of the 2008 riots - the Dalai Lama announced his deci-

25 S. Cook, Tibetan Buddhism: Religious Freedom in China: https:// freedomhouse.org/report/2017/battle-china-spirit-tibetan-buddhism-religious-freedom [access: 10.12.2020].

26 J. Yardley, E. Wong, Dalai Lama Gives Up Political Role, "New York Times", 10.03.2011, http: www.nytimes.com/2011/03/11/world/ asia/11tibet.html [access: 23.02.2021]. 
sion to hand over all his remaining political authority to the prime minister of the Tibetan government in exile, insisting on his wish to have a constructive dialogue over autonomy with the Chinese government; but this was not welcome by the CCP. Instead, the government intensified its control over religious centres, and in October that year opened its own Tibet Buddhist Theological Institute in Lhasa, intended to form loyal Buddhist religious leaders who would contrast what the regime defines "the Dalai clique". According to typically descriptive official statements, the institute features "a distinctive Tibetan architecture style [...] and has 150 students including tulkus and monks from various Tibetan Buddhist sects."27

Funding from governmental sources is given to Tibetan Buddhist monasteries or temples - attended also by a growing number of Han Chinese believers - where monks accept the CCP's policy.

At the Sixth Tibet Work Forum held in August 2015, Xi Jinping called for the Party to, among other things, "carry out propaganda and education activities on Marxist motherland view, views on nation, religious view, cultural view; [...] strengthen the identification of the people of various nationalities with the great motherland, with the Chinese nation, with the Chinese culture, with the Communist Party of China, and with socialism with Chinese characteristics; [...] promote the state's common language, and strive to nurture socialist cause builders. ${ }^{28}$

27 “Global Times", 8.05.2013: https://www.globaltimes.cn/content/780238.shtml [access: 10.12.2020].

28 U.S. Congressional-Executive Commission on China, December 2015: https://www.cecc.gov/sites/chinacommission.house.gov/files/documents/2015\%20AR\%20Tibet.pdf [access: 10.12.2020]. 
According to a Freedom House report, while many Tibetan people still occasionally enact open forms of protest, including also nonviolent demonstrations by single brave persons who face imprisonment and torture for showing a portrait of the Dalai Lama or a Tibetan flag,

the majority of Tibetans responded to restrictive religious policies in one of four ways - 'exit,' cooperation, avoidance, and subtle resistance. [...] Until 2008, thousands of Tibetans fled into exile each year. With increased police checkpoints throughout the plateau and a military buildup along the Nepalese border, the 'exit' option has been largely closed off. [...] A sizable contingent of Tibetan Buddhist leaders actively cooperate with the Chinese authorities, while others seek to negotiate with local officials in order to balance their responsibility to followers and compliance with official directives to minimize repression. [...] Monks and nuns occasionally hide among the local community or in surrounding mountains for the period of a patriotic reeducation campaign or other official inspection. [...] Many monks and laypeople secretly retain images of the Dalai Lama or other representations of the spiritual leader that may not be immediately visible to Chinese inspectors. Many Tibetans also educate their children in the privacy of their own homes about the Dalai Lama or other principles of Tibetan Buddhism that they might not otherwise encounter. ${ }^{29}$

I had the privilege to attend several events with the Dalai Lama in Europe, as well as the opportunity to talk to the representatives of the Tibetan government in exile. Their constant advocacy for peace, respect of minority rights, and the freedom of religion has growing audience in many

29 S. Cook, Tibetan Buddhism: Religious Freedom in China: https:// freedomhouse.org/report/2017/battle-china-spirit-tibetan-buddhism-religious-freedom [access: 10.12.2020]. 
countries, also thanks to the support of the International Campaign for Tibet, with headquarters in Washington, DC, and offices in Amsterdam, Brussels and Berlin. ${ }^{30}$

\section{Muslims between tolerance and oppression. The case of the Uyghurs in Xinjiang}

There are probably around 25 million Muslims in China. The largest of the ten predominantly Muslim ethnic groups are the Huis, who are widespread in the Chinese territory and whose native language is Mandarin, and the Uyghurs, who are Turkic-speaking and live in a formally autonomous region in current Western China called Xinjiang (which translates to "New Frontier" in Chinese). Each of these two groups has a population of about 11 million. While Huis are largely assimilated with the Hans, generally integrated into the dominant Han culture and relatively tolerated by the CCP, the Uyghurs - who often refer to their region as 'Eastern Turkistan' and share many more ethnic features with other peoples of Central Asia such as Uzbeks or Kazakhs than with the Hans - have been seriously oppressed in the last decades, as the government claims that many of them may hold extremist Islamic ideology and separatist ideas.

After September 11 2001, the CCP has also been using the frame of the 'Global War on Terror' to justify the repression of the Uyghur population, labeling hundreds of thousands of Muslim Uyghurs as extremists (although this word has no strict juridical definition), separatists, and therefore potentially terrorists.

30 International Campaign for Tibet, https://savetibet.org/ [access: 10.12.2020]. 
I had the opportunity to meet several Uyghur activists for human rights in exile, as well as common Uyghurs living in Kazakhstan - where the 2009 official census estimated them numbering 224,713, mainly inhabiting the areas bordering China in the Almaty region. ${ }^{31}$ Most Uyghurs are actually either the followers of the tolerant Hanafi School of Sunni Islam, or are not religious, while adopting some Muslim cultural traditions. Language and religion, however, along with their concentration in one specific region, constitute important features of a specific Uyghur identity which is perceived with suspicion by the CCP.

The existence of a separatist group named East Turkestan Islamic Movement, which has been accused of several terrorist attacks throughout China and, according to a U.N. Security Council report, in 2011 had about 200 members, ${ }^{32}$ should not evidently imply the bias against millions of people, but the CCP has been conducting a large scale repression:

Over the last several years, it has been estimated that over 1.8 million Uyghurs and members of other predominantly Muslim minorities (Kazakh, Kyrgyz, etc.) have been sent to "reeducation camps," or forced labor centers. Widespread arbitrary detention, political indoctrination, family separation, and pervasive surveillance have all become part of everyday life for all Uyghurs. Having a passport, having traveled to foreign countries, [...] or choosing not to drink or smoke are all actions that could be used as justification for sending someone to a jail or camp. $^{33}$

31 Minority Rights Group International, https://minorityrights.org/ minorities/uyghurs-2/ [access: 15.02.2021].

32 U.N. Security Council, https://www.un.org/securitycouncil/sanctions/1267/aq_sanctions_list/summaries/entity/eastern-turkistan-islamic-movement [access: 26.02.2021].

33 Human Rights Foundation, What's Happening in Xinjiang? 
According to testimonies and reports, torture and sexual abuses are common in the camps, where the internees are barred from practicing religion and indoctrinated on the CCP ideology. Forced sterilizations have also been denounced.

Outside the camps, massive electronic surveillance, frequent evaluations of loyalty in schools and workplaces, invasive visits by CCP' members to homes, and the collection of every possible personal data of Uyghur people in a comprehensive database complete the tight system of control, making it easy for the authorities to find any alleged reason, even in very private life habits, to send anybody to internment. According to a recent publication by a scholar with long field experience,

with time it has become clear that the PRC is at the very least committing acts of 'cultural genocide' against the Uyghurs. In effect, the Chinese state has launched a campaign to destroy Uyghur identity as we know it. [...] The internment camps, in which a significant portion of the Uyghur population has been detained indefinitely and without due process, are at the center of this complex of policies. Inside these camps, the internees are subjected to prison-like conditions, forced to study the Chinese language for long hours, followed by additional hours of being force-fed by the Communist Party propaganda, much of which targets Islam and related Uyghur cultural practices as a dangerous ideology. ${ }^{34}$

The process of forced assimilation also includes the transformation of the landscape of the region, progressively

QEA With Uyghur Activist Jewher Ilham, 29.01.2021, https://hrf.org/ press_posts/whats-happening-in-xinjiang/ [access: 15.02.2021].

34 S.R. Roberts, The War on the Uyghurs: China's Campaign Against Xinjiang's Muslims, Princeton 2020, p. 2. 
leaving - as in other cases - just what the party considers necessary for its official multi-ethnic tolerance and for tourists. Not only is the Uyghur language "gradually being removed from public space", but "there is a campaign to destroy mosques and Muslim graveyards throughout the XUAR [Xinjiang Uyghur Autonomous region], and neighborhoods of traditional Uyghur housing are being demolished." 35

The alteration of the landscape and the 'sinicization', which, according to a senior CCP official, "must be upheld to promote ethnic solidarity and religious harmony," ${ }^{36}$ has recently been extended to other regions where even small Muslim minorities live. This is the case, for instance, of the Sanya Chams or Utsuls of Hainan island (the Southernmost province of China), whose population is only about 10,000 and who are officially considered as Huis, although they are ethnically distinct and speak a different language. A document issued in 2019 by a local Party Committee and provincial authorities, entitled Work Plan for Strengthening the Comprehensive Governance of Huixin Community and Huihui Community, aims at the 'rectification' of habits, symbols and signs, and "mandates that the population is forbidden from wearing a robe or headscarf at work, and pictures with people in a robe or headscarf are not allowed to be posted in the workplaces. ${ }^{137}$ Moreover, the document

35 Ibidem, pp. 3-4.

36 Chinese official says 'sinicization' of religion in Xinjiang must go on, "Reuters", 13.10.2018, https://www.reuters.com/article/us-china-xinjiang-idUSKCN1MN0P9 [access: 15.02.2021].

37 Ling Tian, Sanya Chams Muslim Minority in Hainan: Eradicating an Identity, "Bitter Winter", 13.02.2020: https://bitterwinter.org/sanya-chams-muslim-minority-in-hainan/ [access: 15.02.2021]. 
demands to find out those religiously active among $\mathrm{CCP}$ members; dispatch Party members to join the mosque management committees; [...] stipulates that all the houses, restaurants, and hotels must be investigated. Arabic scriptures, patterns of Mecca prayer, religious slogans, and signs with "Halal" must be removed. Books, pictures, patterns, symbols suspected of promoting what the CCP calls "Saudization," "Arabization," or "Generalization of Halal" must be banned. [...] "Saudi-style" and Arabic-style buildings must be banned. ${ }^{38}$

It's worth mentioning a speech by Xi Jinping, in September 2014, directed at all the Chinese people, including both Hans and minority groups, which concerned enhancing four identifications: "with the Chinese motherland, the Chinese nation, Chinese culture, and the path of socialism with Chinese characteristics" - to which he added, in August 2015, the identification with the CCP. As noticed in a recent publication, signs above the mosques that previously read 'Love the country, love religion' have been replaced and "they now read 'Love the Party, love the country"'39

\section{Christian state-sanctioned denominations and house churches}

Like for other religions, the statistics about the number of Christians in China are not fully reliable. Although the government recognizes three state-regulated Christian organizations, there are many unregistered Christian groups,

38 Ibidem.

39 J. Smith Finley, Securitization, insecurity and conflict in contemporary Xinjiang: has PRC counter-terrorism evolved into state terror?, "Central Asian Survey", 11.03.2019, https://www.tandfonline.com/doi/fu 1l/10.1080/02634937.2019.1586348 [access: 15.02.2021]. 
which often practice in so called 'house churches'. There are reportedly about 20 to 40 million registered Christians, while estimates for unregistered Christians vary from 30 to 90 millions. The number of Catholics, according to a 2010 publication by the Chinese Academy of Social Sciences, is between 6 and 12 million. There are probably between 8,000 and 20,000 Orthodox Christians..$^{40}$

A study of the Pew Research Center, which gives an account also of the necessity to consider multiple sources of data, estimates that in 2010 there were 67 million Christians in China, including 23 million registered (with the stateapproved Three-Self Patriotic Movement Committee) and 35 million unregistered Protestants. The same report notes that governmental data show dramatic growth among officially recognized Protestants and Catholics (the last being registered with the Chinese Catholic Patriotic Association) from 1997 to 2006, with a 60\% increase for Protestants and a $25 \%$ increase for Catholics. ${ }^{41}$

This may have been a reason for concern for the CCP, particularly because of the popularity of Protestantism among the higher educated part of the population, the diffusion of worship in private houses, which are more difficult to control, and the foreign ties of both Protestant denominations and Catholicism. Consequently, the repression of Christians has been reportedly increased, although not to the extension of what happens with Tibetan Buddhists and

40 Immigration and Refugee Board of Canada, China: Estimates of the number of Christians, particularly in the provinces of Fujian, Guangdong and Liaoning, Ottawa, 19.10.2012, https://www.refworld.org/docid/50a9f4012.html [access: 23.02.2021].

41 Pew Research Center, https://www.pewresearch.org/wp-content/ uploads/sites/7/2011/12/ChristianityAppendixC.pdf [access: 23.02.2021]. 
Uyghur Muslims. In some areas crosses have been removed from the tops of churches, in other ones churches have been demolished, and there have been cases of Christian pastors and priests harassed and imprisoned for "inciting to subvert state power." ${ }^{2}$

As for the Catholic Church, we have to consider that the Holy See has not had diplomatic ties with the PRC since 1951, while it remains the last European government to officially recognize the Republic of China in Taiwan. Nevertheless, in the last few years the two Parties have been trying to reach an agreement on the decades long dispute over the bishop appointment process, which for the Holy See is a prerogative of the Pope, while for the PRC is its own decision: This led to the persecution of Catholics loyal to the Pope on the one hand, and to the excommunication of government-appointed bishops on the other hand. However, in September 2018, the two sides reached a Provisional Agreement, signed in Beijing by an undersecretary for the Holy See's Relations with States and a deputy minister for Foreign Affairs of the PRC, which gives the Pope some sort of veto power over future bishop nominees while Pope Francis recognizes several bishops who had been excommunicated. ${ }^{43}$

This Provisional Agreement does not necessarily entail a switch of the official diplomatic relations of the Holy See from the ROC the PRC in the next future, although this cannot be excluded. However, has been declared by Vatican's

42 I. Johnson, How the State Is Co-Opting Religion in China - And What It Means for the Country's Future, "Foreign Affairs", 7.01.2019: https://www.foreignaffairs.com/articles/china/2019-01-07/how-stateco-opting-religion-china [access: 15.02.2021].

43 E. Albert, L. Maizland, Religion in China, backgrounder of the Council on Foreign Relations, last updated 25.09.2020: https://www.cfr. org/backgrounder/religion-china [access: 15.02.2021]. 
sources as "pastoral, non political", with "the shared hope" that it "may favour a fruitful and forward-looking process of institutional dialogue and may contribute positively to the life of the Catholic Church in China, to the common good of the Chinese people and to peace in the world." 4

\section{The xie jiao, banned religious groups}

Besides dealing with the main religious denominations which have more or less ancient historical roots in China, the Chinese government has labeled several religious and spiritual groups as 'xie jiao': a term, already used under the Ming and Qing dynasties, which can be translated "heterodox teachings", but that official documents translate into English as "heterodox cults" or - worse - "evil cults". 45

According to Art. 300 of the Chinese Criminal Code,

Whoever organizes and utilizes superstitious sects, secret societies, and evil religious organizations or sabotages the implementation of the state's laws and executive regulations by utilizing superstition is to be sentenced to not less than three years and not more than seven years of fixed-term imprisonment; when circumstances are particularly serious, to not less than seven years of fixedterm imprisonment.

Whoever organizes and utilizes superstitious sects, secret societies, and evil religious organizations or cheats others by utilizing superstition, thereby giving rise to the

44 Provisional Agreement between Holy See and China, "Vatican News", 22.09.2018, https://www.vaticannews.va/en/vatican-city/ news/2018-09/china-holy-see-agreement-appointment-bishops.html [access: 26.02.2021].

45 Introvigne M., If Your Religion is a Xie Jiao, You Go to Jail - But What Is A Xie Jiao?, "Bitter Winter", 8.09.2018: https://bitterwinter.org/ what-is-a-xie-jiao/ [access: 15.02.2021]. 
death of people is to be punished in accordance with the previous paragraph.

Whoever organizes and utilizes superstitious sects, secret societies, and evil religious organizations or has illicit sexual relations with women, defraud money and property by utilizing superstition is to be convicted and punished in accordance with the regulations of articles 236, 266 of the law. ${ }^{46}$

Incidentally, jurists may notice the bizarre reference to "illicit sexual relations with women" in paragraph 3, which apparently excludes that sexual relations "with men" can be illicit, and might imply that "Whoever" refers only to men. This is, in my opinion, actually consistent with a way of formulating a criminal code that is intended to affirm the prevalence of the state power over the individual, not caring about basic juridical principles such as the equality of every person before the Law - what is clearly stated, among else, by Art. 7 of the Universal Declaration of Human Rights.

As a matter of fact, provisions of Art. 300 are often applied against people who, out of the officially recognized religious organizations, simply attend worship services, share the gospel, distribute religious books, or even practice spiritual exercises.

The last is the case, in particular, of Falun Gong or Falun Dafa, which can be translated as "Buddhist Law": a spiritual movement, founded by Li Hongzhi in 1992, which blends traditional qigong exercises with Buddhism and Taoism. As an American supporting group summarizes, it is "an ancient way of improving mind and body", based on "five gentle ex-

46 Criminal Law of the People's Republic of China, https://www.fmprc.gov.cn/ce/cgvienna/eng/dbtyw/jdwt/crimelaw/t209043.htm [access: 26.02.2021]. 
ercises, including a meditation", as "ways to improve health and energy", and on "the values of Truthfulness, Compassion, and Forbearance." ${ }^{47}$ The followers are also encouraged "to be good citizens by leading a moral life, not to smoke or drink or have sexual relations outside marriage, and to resist the consumerism that has swept China." ${ }^{48}$

Being in line with several traditional practices, the Falun Gong was tolerated though not registered for about seven years, reaching, according to the government, about 70 million practitioners in 1999. In April that year, when more than 10,000 of them staged an unexpected, well organized silent demonstration in Beijing asking for the release of some detained adherents and more freedom, ${ }^{49}$ the government started to view them as a potential threat and launched a crackdown and a demonization campaign.

Long explanations of all the alleged 'evils' of the Falun Gong can be found in a number of the PRC's official publications. A short summary opens, for instance, an article on the web site of the Mission of PRC to the European Union:

Like many other cults in the world, Falun Gong has the nature of being anti-mankind, anti-science and anti-society. It practices cult leader worship, spreads fallacies, exercises mind control, ruins human lives and endangers society. [...] At the request of all people, the Chinese government has banned the Falun Gong cult in accordance with the law in order to protect human rights and safe-

47 Friends of Falun Gong, What is Falun Gong?, https://fofg.org/ what-is-falun-gong/ [access: 26.02.2021].

48 Faison S., In Beijing: A Roar of Silent Protesters, "New York Times", 27.04.1999, https://web.archive.org/web/20151017003808/http://partners.nytimes.com/library/world/asia/042799china-protest.html [access: 26.02.2021].

49 Ibidem. 
guard social stability. This is also a great contribution to the world anti-cult course..$^{50}$

Typically, the article claims that banning the Falun Gong had been requested by "all people" and "in order to protect human rights", while only the second declared goal - to "safeguard social stability", meaning the established system of power - is actually important for the CCP.

Notwithstanding the fact that the accusations of "cult leader worship" and exercising "mind control" are made by a party that is well-known for systematically doing the same, the article explains that,

On 22 July 1999, in accordance with the demand by the people, the Chinese government decided to outlaw Falun Gong. The Ministry of Public Security of the People's Republic of China issued a public notice prohibiting the hanging or posting anywhere of the banners, pictures, emblems advocating "Falun Dafa" (Falun Gong) and all activities, including assemblies, processions and demonstrations etc., organized by "Falun Gong".

The Falun Gong diaspora is widespread in many countries, has a strong basis in the USA, where their founder currently live, and does advocacy campaigns for their rights in relevant international fora. I have often had the opportunity to discuss with them in conferences and in private meetings, and I would argue that, because of the persecution by the $\mathrm{CCP}$, they now tend to act not only as individual practitioners, but also as a nonviolent oppositional movement in exile.

50 Mission of the PRC to the EU, Frequently Asked Questions on the Issue of Falun Gong, 9.03.2004, http://www.chinamission.be/eng/more/ flgwt/t72351.htm [access: 26.02.2021].

51 Ibidem. 
On a relatively positive note, according to a recent Freedom House's report, "Falun Gong practitioners, though still subject to severe abuses, are experiencing reduced persecution in many locales, as top officials driving the campaign have been purged in intraparty struggles, and years of grassroots outreach by adherents and their supporters have won over some lower-level authorities." ${ }^{2}$

Another persecuted group, labeled as "evil cult" since 1995, is the Church of the Almighty God (CAG), also known as Eastern Lightning. It is the largest Chinese new religious movement with a Christian inspiration.

According to a paper presented by three Western scholars in 2019, the CAG

originated in 1991 around the revelations of a woman, whose name is (probably) Yang Xiangbin, who was later recognized as [...] the second coming of Jesus Christ, the incarnated Almighty God. Around this belief a complete system of dispensationalist theology grew, distinguishing three ages of the history of humanity, the Age of Law, the Age of Grace, and the present Age of Kingdom, which will eventually lead into the glorious Age of the Millennial Kingdom. CAG's own statistics claim that more than 400,000 CAG members have been arrested in China from 2011 to date. These figures cannot be independently confirmed but certainly there are several CCP documents calling for massive anti-CAG campaigns, monetary rewards are publicly offered to those who denounce CAG members, and there are frequent references in Chinese media to hundreds of arrests in one or another province..$^{53}$

52 The Battle for China's Spirit. Religious Revival, Repression, and Resistance under Xi Jinping, Freedom House Special Report, February 2017, https://freedomhouse.org/sites/default/files/2020-02/FH_ChinasSprit2016_FULL_FINAL_140pages.pdf [access: 15.02.2021].

53 M. Introvigne, J.T. Richardson, R. Šorytè, Religion-Based Refugee Claims in Trans-National Perspective: Asylum Cases Involving The 
By June 2019, as the same paper reports, more than 5,500 members of the CAG had requested asylum in Europe, USA, Canada, Australia, New Zealand, Japan or South Korea. I have personally been contacted by several asylum seekers in Italy, who face the risk of not being recognized as refugees and consequently being deported to China.

\section{The "best practices" examples of Taiwan and Hong Kong}

The Republic of China settled from 1949 in Taiwan (which acts as a sovereign state, while the PRC claims it as one of its provinces) has a peculiar situation with ethnic minorities, being home of 16 officially recognised indigenous peoples and about 10 small other indigenous groups. Although they constitute only a $2.4 \%$ of Taiwan's population, numbering about $559,000,{ }^{54}$ as the descendants of peoples that had inhabited the island for thousands of years they have legitimately obtained, since the beginning of the democratization process in the 1980s, to be designed with the self-selected term 'aborigine', instead of "the state-given term 'mountain compatriot' (shanbao), which is viewed as assimilationist," used under the authoritarian Chiang Kai-shek's regime. ${ }^{55}$ The Alliance of Taiwan Aborigines (ATA) was established

Church of The Almighty God, https://www.cesnur.org/2019/CAG-Tartu. pdf [Access: 28.02.2021].

54 Minority Rights Group International, https://minorityrights.org/ country/taiwan/ [access: 28.02.2021] .

55 Kun-hui Ku, Rights to Recognition: Minority/Indigenous Politics in the Emerging Taiwanese Nationalism, "Social Analysis", 6.2005, https:// www.researchgate.net/publication/233485927_Rights_to_Recognition_ MinorityIndigenous_Politics_in_the_Emerging_Taiwanese_Nationalism [access: 28.02.2021]. 
in 1984 to advocate for aboriginal rights, including claim to self-determination and participation in the decision-making processes on issues directly related to them. In 1996, under the Executive Yuan, a Council for Aboriginal Affairs was established, which in 2002 was renamed as the Council of Indigenous Peoples. I had the opportunity to discuss local issues freely during two visits to Taiwan, where I also met with representatives of local tribes in their own territories.

As for the Hans, which constitute around 97 per cent of the population, while most of them "belong to two groups considered to be 'Native Taiwanese': the Hokkien who originally began immigrating from China's southern Fujian province in the 16th century and represent about 70 per cent of the total population, and the Hakka (around 15 per cent of the total population), who migrated in the same period from China's Guangdong province", others "came from the mainland with the Nationalist Kuomintang (KMT) government and troops after losing the Chinese Civil War to the Communists in 1949."56

As for freedom of religion, Taiwan can be considered an example of "good practice", because every traditional believe, revealed religion, and new religious movement are free - including among else Buddhism, Taoism (often combined and worshipped in same temples), different Christian denominations (diffused also among the majority of the indigenous population), Mormonism, the Unification Church, Islam, Judaism, Hinduism, and folk religions with aspects of shamanism and ancestor worship. Folk religion is also often practiced along with other religions. The Dalai Lama was allowed to visit Taiwan in 1997, in 2001 and in 2009, and in 2020 has re-

56 Ibidem. 
ceived an invitation to return to the island the following year, with favourable statements by the Taiwanese government. ${ }^{57}$

Among the "estimated 711,000 foreign workers, primarily from Southeast Asia", there are more than 270,000 people from Indonesia, who are predominantly Muslim, and about 155,000 from the Philippines, who are predominately Roman Catholic..$^{58}$

A perfect example of "good practice" for the PRC to follow, in my opinion, is the complete freedom of practicing for Falun Gong, as the very fact that in Taiwan there are hundreds of thousands of Falun Gong practitioners, and even large Falun Gong events can frequently take place, shows that they do not cause any trouble for "social stability" - what is officially stated by the PRC as a reason to criminalize them as members of an "evil cult". Falun Gong is also practiced by followers "of Buddhism, Taoism, and other traditional religions".59

Taiwan is active in the promotion of religious freedom in the world, and a Taiwan International Religious Freedom Forum (TIRFF), "a multi-faith gathering of religious leaders, government representatives, and NGO leaders to promote religious freedom around the world," was held in $2019 .{ }^{60}$

Till now respect for minority and religious rights has been also basically guaranteed in Hong Kong, which is officially a Special Administrative Region and, for 50 years starting

57 The Dalai Lama wishes to visit Taiwan in 2021, "Taiwan News", 9.09.2020, https://www.taiwannews.com.tw/en/news/4004858 [access: 28.02.2021].

58 U.S. Department of State, 2019 Report on International Religious Freedom: Taiwan, https://www.state.gov/reports/2019-report-on-international-religious-freedom/taiwan/ [access: 28.02.2021].

59 Ibidem.

60 Taiwan International Religious Freedom Forum, TIRFF, http:// tirff.org/ [access: 28.02.2021]. 
from the restoration to China by the United Kingdom on 1 July 1997, should be "vested with executive, legislative and independent judicial power, including that of final adjudication". ${ }^{61}$

In particular, "Rights and freedoms, including those of the person, of speech, of the press, of assembly, of association, of travel, of movement, of correspondence, of strike, of choice of occupation, of academic research and of religious belief")..$^{62}$

The total number of people belonging to ethnic minorities in Hong Kong was around 584,000 in 2016, constituting $8.0 \%$ of the total population, with an increase in the last decade "fuelled largely by the influx of Southeast Asians." ${ }^{63}$ Official records of the Special Administrative Region mention the presence of "a variety of religions in Hong Kong, including Buddhism, Taoism, Christianity, Confucianism," (which is not classified as a religion by the PRC) "Islam, Hinduism, Sikhism and Judaism". ${ }^{64}$

As in Taiwan, also in Hong Kong, Falun Gong followers have been generally able to practice their exercises, distribute their literature, and conduct public events. However, in 2019, "Falun Gong practitioners reported harassment from groups they said were connected to the Chinese

61 Joint Declaration of the Government of the United Kingdom of Great Britain and Northern Ireland and the Government of the People's Republic of China on the Question of Hong Kong, Beijing, 19 December 1984 - Art. 3, clause 3: http://english1.english.gov.cn/2007-06/14/content_649468.htm [access: 1.02.2021].

62 Ibidem.

63 Legislative Council of Hong Kong, "Religious facilities in Hong Kong", 8.12.2017, https://www.legco.gov.hk/research-publications/english/1718fs01-religious-facilities-in-hong-kong-20171208-e.pdf [access: 27.02.2021].

64 Ibidem. 
Communist Party (CCP) and difficulty renting venues for large events, including from the SAR government", and in November that year "a printing warehouse for the Epoch Times Hong Kong Edition, a Falun Gong-associated media outlet, was subject to an arson attack by four masked assailants armed with batons." ${ }^{65}$

These developments follow the increasing efforts made by the central government of the PRC, in the last few years, to considerably reduce Hong Kong's autonomy.

The near future will probably show whether the CCP will consider at least part of the freedom experience of Hong Kong and Taiwan a viable way to follow, coming to conciliatory terms with the instances of the big part of the society also in Mainland China, or will continue its policies of co-opting loyal religious leaders, while oppressing - in some cases, giving rise to accusations of cultural genocide - millions of people who refuse homologation. This second option, which in my opinion amounts to imposing party ideology as a pervasive religion itself, would certainly face massive resistance in the country and increased strong criticism internationally, notwithstanding the widespread use of propaganda and disinformation campaigns in which the CCP is actively engaged worldwide; and this might prove simply not convenient for the élite in power, recommending a more pragmatic approach to them.

65 U.S. Department of State, 2019 Report on International Religious Freedom: China - Hong Kong, https://www.state.gov/reports/2019-report-on-international-religious-freedom/china/hong-kong/ [access: 27.02.2021]. 


\section{Bibliography}

Albert E., Maizland L., Religion in China, backgrounder of the Council on Foreign Relations, last updated 25.09.2020: https://www.cfr.org/backgrounder/religion-china.

Barnett R., Restrictions and Their Anomalies: The Third Forum and the Regulation of Religion in Tibet, "Journal of Current Chinese Affairs", 1.12.2012, https://journals. sagepub.com/doi/10.1177/186810261204100403.

Bogusz M., Jakóbowski J., The Chinese Communist Party and its State - Xi Jinpings' Conservative Turn, Warsaw, 2020, https://www.osw.waw.pl/sites/default/files/REPORT_The-Chinese-Communist-Party_net.pdf

Central Tibetan Administration (in exile), https://tibet.net/ important-issues/factsheet-immolation-2011-2012/.

China Internet Information Center, http://www.china.org. cn/e-white/Freedom/f-1.htm.

Chinese official says 'sinicization' of religion in Xinjiang must go on, "Reuters", 13.10.2018, https://www.reuters.com/article/us-china-xinjiang-idUSKCN1MNOP9.

Cook S., The Battle for China's Spirit - Religious Revival, Repression, and Resistance under Xi Jinping, 2017: https:// freedomhouse.org/report/special-report/2017/battlechinas-spirit.

Cook S., Tibetan Buddhism: Religious Freedom in China: https://freedomhouse.org/report/2017/battle-chinaspirit-tibetan-buddhism-religious-freedom.

Criminal Law of the People's Republic of China, https:// www.fmprc.gov.cn/ce/cgvienna/eng/dbtyw/jdwt/crime law/t209043.htm.

Everington K., Dalai Lama wishes to visit Taiwan in 2021, "Taiwan News", 9.09.2020, https://www.taiwannews.com.tw/en/ news/4004858. 
Faison S., In Beijing: A Roar of Silent Protesters, "New York Times", 27.04.1999, https://web.archive.org/web/20151 017003808/http://partners.nytimes.com/library/world/ asia/042799china-protest.html.

Fifield A., China celebrates 'very happy lives' in Xinjiang, after detaining 1 million Uighurs, "The Washington Post", 30.07.2019, https://www.washingtonpost.com/world/ china-celebratesvery-happy-lives-in-xinjiang-after-detaining-a-million-uighurs/2019/07/30/0e07b12a-b28011e9-acc8-1d847bacca73_story.html.

Freedom House, The Battle for China's Spirit. Religious Revival, Repression, and Resistance under Xi Jinping, 2.2017, https://freedomhouse.org/sites/default/files/2020-02/ FH_ChinasSprit2016_FULL_FINAL_140pages.pdf.

Friends of Falun Gong, What is Falun Gong?, https://fofg. org/what-is-falun-gong/.

Gladney D.C., Dislocating China: Reflections on Muslims, Minorities, and Other Subaltern Subjects, London 2004. Hillman B., Ethnic Conflict and Protest in Tibet and Xinjiang, Introduction to Hillman B., Tuttle G. (eds.), Ethnic Conflict and Protest in Tibet and Xinjiang: Unrest in China's West, New York, N.Y. 2016.

Human Rights Foundation, What's Happening in Xinjiang? QEA With Uyghur Activist Jewher Ilham, 29.01.2021, https://hrf.org/press_posts/whats-happening-in-xinjiang/.

Immigration and Refugee Board of Canada, China: Estimates of the number of Christians, particularly in the provinces of Fujian, Guangdong and Liaoning, Ottawa 19.10.2012, https://www.refworld.org/docid/50a9f4012.html.

International Campaign for Tibet, https://savetibet.org/. Introvigne M., If Your Religion is a Xie Jiao, You Go to Jail 
- But What Is A Xie Jiao?, “Bitter Winter”, 8.09.2018: https://bitterwinter.org/what-is-a-xie-jiao/.

Introvigne M., Inner Mongolia Protests Against Cultural Genocide Gain Momentum, "Bitter Winter", 9.01.2020, https://bitterwinter.org/inner-mongolia-protestsagainst-cultural-genocide-gain-momentum/.

Introvigne M., Richardson J.T., Šorytė R., Religion-Based Refugee Claims in Trans-National Perspective: Asylum Cases Involving The Church of The Almighty God, https://www.cesnur.org/2019/CAG-Tartu.pdf.

Jianli Yang, Lianchao Han, China's war against the Mongolian language, “The Washington Times”, 29.09.2020, https://www.washingtontimes.com/news/2020/sep/29/ chinas-war-against-the-mongolian-language/.

Johnson I., How the State Is Co-Opting Religion in ChinaAnd What It Means for the Country's Future, "Foreign Affairs", 7.01.2019: https://www.foreignaffairs.com/articles/china/2019-01-07/how-state-co-opting-religionchina

Joint Declaration of the Government of the United Kingdom of Great Britain and Northern Ireland and the Government of the People's Republic of China on the Question of Hong Kong, Beijing, 19 December 1984, http://english1. english.gov.cn/2007-06/14/content_649468.htm.

Kun-hui Ku, Rights to Recognition: Minority/Indigenous Politics in the Emerging Taiwanese Nationalism, "Social Analysis", 6.2005, https://www.researchgate.net/publication/233485927_Rights_to_Recognition_MinorityIndigenous_Politics_in_the_Emerging_Taiwanese_Nationalism.

Legislative Council of Hong Kong, "Religious facilities in Hong Kong”, 8.12.2017, https://www.legco.gov.hk/re- 
search-publications/english/1718fs01-religious-facilitiesin-hong-kong-20171208-e.pdf.

Ling Tian, Sanya Chams Muslim Minority in Hainan: Eradicating an Identity, "Bitter Winter", 13.02.2020: https:// bitterwinter.org/sanya-chams-muslim-minority-in-hainan/.

Majumdar S., Recent Chinese dealings with faith groups reflect a pattern of government restrictions on religion, 11.10.2018: https://www.pewresearch.org/fact-tank/2018/10/11/ recent-chinese-dealings-with-faith-groups-reflect-a-pattern-of-government-restrictions-on-religion/.

Mann J., Dalai Lama Shifts Stand on Tibet Independence, "Los Angeles Times", 16.06.1988, https://www.latimes. com/archives/la-xpm-1988-06-16-mn-6860-story.html.

Minority Rights Group International, https://minorityrights.org/country/taiwan/.

Minority Rights Group International, https://minorityrights.org/minorities/uyghurs-2/.

Mission of the PRC to the EU, Frequently Asked Questions on the Issue of Falun Gong, 9.03.2004, http://www.chinamission.be/eng/more/flgwt/t72351.htm.

Pew Research Center, https://www.pewresearch.org/wpcontent/uploads/sites/7/2011/12/ChristianityAppendixC.pdf.

Provisional Agreement between Holy See and China, "Vatican News", 22.09.2018, https://www.vaticannews.va/en/ vatican-city/news/2018-09/china-holy-see-agreementappointment-bishops.html.

Roberts S.R., The War on the Uyghurs: China's Campaign Against Xinjiang's Muslims, Princeton 2020.

Rudelson J., WJankowiak W., Acculturation and Resistance: Xinjiang Identities in Flux, in Starr F.S. (ed), Xinjiang: 
China's Muslim Borderland, London \& New York 2015 ( $1^{\text {st }}$ ed. Armonk, New York, 2004).

Shanghai Cooperation Organization, http://eng.sectsco.org/ about_sco/.

Smith Finley J,, Securitization, insecurity and conflict in contemporary Xinjiang: has PRC counter-terrorism evolved into state terror?, "Central Asian Survey", 11.03.2019, https://www.tandfonline.com/doi/full/10.1080/026349 37.2019.1586348.

Song Yongyi, Chronology of Mass Killings during the Chinese Cultural Revolution (1966-1976): https://www. sciencespo.fr/mass-violence-war-massacre-resistance/ en/document/chronology-mass-killings-during-chinesecultural-revolution-1966-1976.html.

Taiwan International Religious Freedom Forum, TIRFF, http://tirff.org/.

Tashi Phuntsok, Revisiting the "Cultural Revolution" in Tibet, 31.10.2016, https://tibet.net/revisiting-the-culturalrevolution-in-tibet/.

The Nobel Prize, https://www.nobelprize.org/prizes/peace/ 1989/lama/facts/.

Tsering Shakya, Beyond development and diversity (interview), "Himal Southasian", 25.06.2018, https://www.himalmag.com/beyond-development-and-diversity-historian-tsering-shakya-interview/.

UNICEF, https://www.unicef.cn/en/figure-14-percentageethnic-minority-groups-province-2015\#: :text=China\%20 is $\% 20$ comprised $\% 20$ of $\% 2056$, mostly\%20residing $\% 20$ in\%20western\%20China.

U.N. Security Council, https://www.un.org/securitycouncil/sanctions/1267/aq_sanctions_list/summaries/entity/ eastern-turkistan-islamic-movement. 
U.S. Congressional-Executive Commission on China, December 2015: https://www.cecc.gov/sites/chinacommission. house.gov/files/documents/2015\%20AR\%20Tibet.pdf.

U.S. Department of State, 2019 Report on International Religious Freedom: China - Hong Kong, https://www.state. gov/reports/2019-report-on-international-religious-freedom/china/hong-kong/.

U.S. Department of State, 2019 Report on International Religious Freedom: Taiwan, https://www.state.gov/ reports/2019-report-on-international-religious-freedom/ taiwan/.

Vickers E., Defining the Boundaries of 'Chineseness' - Tibet, Mongolia, Taiwan and Hong Kong in Mainland History Textbooks, [in:] What Shall We Tell the Children? International Perspectives on School History Textbooks. Research in Curriculum and Instruction, eds. S.J. Foster, K.A. Crawford, Charlotte, NC 2006, https://www.academia.edu/6873214/Defining_the_Boundaries_of_Chineseness_Tibet_Mongolia_Taiwan_and_Hong_Kong_ in_mainland_history_textbooks?swp=rr-rw-wc-5157469. Xinhua, Tibet Buddhist Theological Institute in Nyetang, Lhasa, "Global Times", 8.05.2013, https://www.globaltimes.cn/content/780238.shtml.

Yardley J., Wong E., Dalai Lama Gives Up Political Role, "New York Times", 10.03.2011, http: www.nytimes. com/2011/03/11/world/asia/11 tibet.html.

Yuan Haiwang, Chinese Ethnicities and Their Culture: An Overview, 2008, http://digitalcommons.wku.edu/dlps_ fac_pub/23. 


\begin{abstract}
In dealing with its officially registered 56 'nationalities', including the dominant Han population, the People's Republic of China has been adopting policies varying from marginalization to assimilation, and in some cases, to what some scholars argue, may be defined "cultural genocide". With the fast economic growth since the 1990s, the state has devoted huge resources to what it calls the modernization of the theoretically autonomous regions, but has not cared of protecting minority rights. As for freedom of religion, policies have aimed to rigidly control the practitioners, with the Chinese Communist Party supervising a system of 'recognized religions' and repressing other groups of believers. In different moments, demolitions and partial reconstructions of monasteries and temples have taken place, along with the promotion of loyal religious chiefs and the oppression of those who are not willing to accept the CCP's pervasive ideology. What was particularly hard was the suppression of Uyghur Muslim believers and of Tibetan Buddhists who revere the Dalai Lama, as well as of Falun Gong and other groups labeled as "evil cults".

Several cases show a somehow paradoxical attitude of the Chinese government when applying a strongly unifying ideology within its territory, while officially using a relativist cultural approach when it comes to the effective implementation of International Human Rights Law.

This article mostly takes into consideration 'Mainland China'; it then refers to Taiwan as an example of a different way to deal with minorities, and mentions the situation of Hong Kong.
\end{abstract}

Keywords: China, Religion, Minorities, Tibet, Dalai Lama, Uyghurs, Falun Gong, Church of Almighty God 


\section{The Decline of Freedom of Expression in} Japan: Political Interference and Blackmail

\section{A worrying sign}

The freedom of expression in Japan has significantly declined during the last decade. In the 2020 World Press Freedom Index, Japan ranks $66^{\text {th }}$ out of 180 countries. It is the lowest among $\mathrm{G} 7$ countries and $33^{\text {rd }}$ among 37 OECD countries. Among three liberal East Asian countries, Japan is the lowest. South Korea is $42^{\text {nd }}$ and Taiwan $43^{\text {rd }}$. When the Reporters Without Borders (RSF) started the World Press Freedom Index in 2002, Japan ranked relatively high $26^{\text {th }}$. Its ranking fell to $51^{\text {st }}$ during the conservative Junichiro Koizumi administration from 2002 to 2006, rose to $11^{\text {th }}$ in 2010 during the short-lieved Yukio Hatoyama's Democratic administration, and dropped drastically to $53^{\text {rd }}$ in 2013 after the 2011 Fukushima nuclear disaster. Under the nationalist conservative administration of Shinzo Abe (December 2012 to September 2020), Japan's downward trend of press freedom became a clear pattern. The latest Japanese NGO report on the freedom of expression describes the current situation as "a crisis for freedom of opinion and expression."

1 NGO Coalition for Free Expression \& Open Information in Japan (NCFOJ), p. 5. 
There are systemic problems in the Japanese media industry that have affected the ranking. The customary system of "kisha clubs" (reporters' clubs), for example, has been long criticized as it effectively excludes minor media, freelance journalists, and foreign correspondents.

However, the downward trend of the last decade can be largely attributed to increased political interference and envigorated far right activism under the nationalist conservative administration. Political interference may take forms such as demands for "fairness" in reporting or behind-thescenes complaints about particular casters. ${ }^{2}$ Pressures come from government officials or influential politicians. There is a legal basis that makes such political interference possible, e.g., Article 4 of the Broadcast Act. ${ }^{3}$ The article obliges broadcasters, 1) not to harm public security nor public morals, 2) to maintain political fairness, 3) not to distort the facts in news reporting, and 4) in dealing with the issues with disagreements, to clarify the issues from as many angles as possible.

The Japan's Broadcast Act has been criticized at the $\mathrm{Hu}$ man Rights Council. During the Universal Periodic Review of Japan in 2018 (Third Cycle), the Unites States recommended "repealing Article 4 of the Broadcast Act" (para. 161.130) and Austria - removing "legal basis for undue

2 There are several allegations about the ousting of casters who didn't report along the government lines. Kensuke Okoshi of the NHK's prime time news program, and Hiroko Kuniya of a NHK's flagship program of investigative journalism, Shigetada Kishii of the TBS's popular late night news program were terminated after they allegedly embarrassed the government. See J. Kingston, p. 882.

3 The Broadcast Act was promulgated in May 1950 and has been amended many times. The four norms that broadcasters must comply with are my translation. 
government interference" (para. 161.132). ${ }^{4}$ The Special Rapporteur on the freedom of expression in his 2017 report on the mission to Japan wrote that "a non-independent government agency should not be in the position of determining what is fair" and recommended that the Japanese government "repeal article 4 of the Broadcast Act". Article 174 of the act gives power to the Minister of Internal Affairs and Communications to suspend a license when "a broadcaster violates provisions of this law or disobeys orders or measures issued based on the law". These articles make broadcasters particularly vulnerable to complaints from politicians.

Political interference is not limited to broadcasting. Under the Textbook Examination system based on the 1947 School Education Law, ${ }^{6}$ the Minister of Education, Culture, Sports, Science and Technology authorizes school textbooks for elementary, junior high, senior high and other schools. Publishers must revise their textbooks, especially those of Japanese history, in accordance with instructions of the government. ${ }^{7}$ Schools can use only government-authorized textbooks. The Passport Law authorizes the foreign minis-

4 Report of the Working Group on the Universal Periodic Review, Japan, Human Rights Council, 4 January 2018, A/HRC/37/15.

5 Report of the Special Rapporteur on the promotion and protection of the right to freedom of opinion and expression on his mission to Japan, 15 June 2017, A/HRC/35/22/Add.1, par. 20.

6 On the Text Examination system by the government, see the Foreign Ministry's explanation in English. https://www.mofa.go.jp/policy/ education/textbooks/overview-2.html [access: 11.01.2021].

7 Saburo Ienaga, Professor of history at the Tokyo University of Education, filed three lawsuits against the government over the constitutionality of the government examination system of school textbooks itself and over the content of the textbook he wrote. For a compact review of the textbook controversy in Japan, see T. Hamada. 
ter to suspend a passport, and this has been used to refuse a passport to journalists traveling to conflict zones. ${ }^{8}$ The government can cancel promised funding to events that stir controversy ${ }^{9}$ and can remove critical academics from public expert bodies. ${ }^{10}$

These institutionalized political interferences in freedom of expression, however, would not have been that effective if they had not been combined with orchestrated blackmail and attacks by far-right activists. In fact, it is such combined pressures that have effectively shrunk freedom of expression in Japan. Government officials and politicians renounce unlawful violence and perpetrators are sometimes punished. But far-right activists rarely show remorse, and incidents repeat.

Political violence in Japan has a long history. It continued even after World War II, targeting a wide range of individuals from the left to liberals, and even to conservatives who they deemed had betrayed "promises". In 1960, the Socialist Party chair Inejiro Asanuma was stabbed to death by a 17-year-old activist when he was speaking before an audience of a few thousands at a large public hall in Tokyo.

8 Well-known recent cases include Yuichi Sugimoto, Kosuke Tsuneoka and Jumpei Yasuda, all journalists who went to war zones in the Middle East. See: related news on Japan in 2019 at the website of the Reporters Without Borders.

9 The Agency of Cultural Affairs suspended its promised subsidy of 78 million yen to the Aichi Triennale 2019 art festival in Nagoya after the festival stirred an uproar with its exhibition, "After 'Freedom of Expression?" which included a statue of a young girl symbolizing "comfort women" and a burned image of what appeared to be Emperor Hirohito. The Agency later retracted the decision and paid a reduced amount of 66 million yen to the art festival.

10 Two cases highlighted the recent trend of exclusion of critical academics from public positions. See the section, Academics under Fire, of this article. 
From 1987 to 1988, four offices of the liberal Asahi Shimbun newspaper were targeted. In the second attack on the Hanshin bureau office at one night in 1987, 29-year-old reporter Tomohiro Kojiri was shot dead by an unknown gunman and another reporter seriously injured. The perpetrator was not identified. In 1990, conservative Nagasaki Mayor Hitoshi Motoshima was shot at a close range from behind after he mentioned the emperor's war responsibility. He narrowly survived. In 2002, centrist politician Koki Ishii was stabbed to death by a far-right activist when he was investigating corruption cases of parliamentarians and bureaucrats. In 2006, the residence of conservative politician and former cabinet secretary Koichi Kato was set on fire after he criticized Prime Minister Koizumi’s visit to Yasukuni Shrine.

During the past decade such violent attacks have become rare. However, memories of violence are still vivid, and threats and blackmail are common not only to the target persons but also to their families and workplaces. Now the cyberspace provides a perfect instrument for anonymous verbal attacks. As a result, cyberbullying is becoming a new threat for the freedom of expression. And there is a natural fear that violence may resume if threats have turned out to be ineffective. In this chapter, I describe underlying political controversies in Japan and examine the modus operandi of recent political interference in the freedom of expression and blackmail to those who speak out.

\section{Two themes: wartime atrocities and post-war pacifism}

Many of the controversies in contemporary Japan revolve around two closely related themes, i.e., post-war pacifism 
and wartime atrocities. For those who think it necessary to enhance military alliance with the United States to defend the country from China, the pacifist constitution is an obstacle as its Article 9 renounces "war as a sovereign right of the nation and the threat or use of force as a means of settling international disputes" and denies the maintenance of "land, sea, and air forces, as well as other war potential". With the interpretation that Article 9 does not deprive Japan of its right to self-defense, Japan possesses military power, namely, the Self-Defense Forces (SDF). The function of Article 9 has been to deter the SDF from directly engaging in combat. The dominant conservative Liberal Democratic Party (LDP) wants to put an end to this uncomfortable ambiguity of the status of the SDF, even though the majority of the Japanese apparently do not support any change to Article 9. ${ }^{11}$ However, the change of Article 9 is only an item in the more comprehensive transformation of Japan to a future state with a more enhanced role of the emperor, more emphasis on the values of social harmony and family, and further consolidated power to impose conformity and loyalty. ${ }^{12}$ As steps toward that direction, the Abe administration established two controversial laws. One is the Desginated

11 The Asahi Shimbun's opinion poll on Article 9 in March-April 2020 showed that $65 \%$ of the respondents did not support an amendment. Ironically, those against the amendment increased during the Abe administration from 52\% in 2013. "Asahi Shimbun", 3.05.2020. https:// digital.asahi.com/articles/ASN5271Z3N4ZUZPS005.html [access: 15.01.2021]. A similar opinion poll by the Jiji News Agency in June 2020 showed that $69 \%$ were against an amendment to Article 9. "Jiji.com", 22.06.2020. https://www.jiji.com/jc/article?k=2020062100234\&g=soc [access: 15.01.2021].

12 Jiyu Minshu To, Nihonkoku Kenpo Kaise Soan [A Draft for a New Constitution for Japan], 2012. For a detailed review of the draft, see: C.F. Goodman. 
Secret Protection Act in 2013. This law makes a leak of classified information or an attempt to obtain such information punishable up to ten years. Complicity, instigation, or agitation can also be punished. It effectively kills whistleblowing. The other is a set of national security bills that passsed the Diet in 2015. The bills recognize the right to collective self-defense, which previous governments had regarded unconstitutional, and allow Japan to use force when a Japan's ally such as the US is attacked and Japan also comes under a serious threat or the lives of the Japanese people face a serious danger. The bills also allow the SDF to provide goods and services for foreign forces and also to search and rescue missing soldiers of foreign forces. These provisions are intended to enhance alliance with the United States further.

The theme of wartime atrocities concerns the honor of the state of Japan. Nationalist conservatives think that talking about Japanese military's atrocities is to dicredit the honor of our soldiers, and therefore, that they should silence those who speak, write or express their views about such atrocities. They think such stories only benefit China in what they call "history wars." ${ }^{13}$ Politicians would not say that the Tokyo Tribunal was invalid, but Radhabinod Pal, a Tokyo tribunal judge representing India, is hailed among the conservatives as he criticized the tribunal as the victor's retaliation and argued in his dissenting judgement that those accused must be found not guilty. A monument in honor of him was built in 2005 at the Yasukuni Shrine, a shinto shrine dedicated to those who died to protect Japan including those top leaders convicted guilty at the Tokyo

13 "History wars" is a term used by the right-wing Sankei newspaper in 2014 to refer to a battle over history, especially "comfort women". See: M. Yamazaki. 
tribunal. ${ }^{14}$ Paying a visit to Yasukuni Shrine is an act to demonstrate respect for those predecessors.

The Nanjing massacre is a mass killing of Chinese soldiers and civilians by the Japanese army that lasted from December 1937 for several weeks in Nanjing, the seat of the Nationalist government led by Chiang Kai-shek at the time. The number of victims is a subject of debate, and it varies from tens of thousands to 300,000. The Japanese government acknowledges that "the killing of a large number of noncombatants, looting and other acts occurred" in Nanjing, even though it is difficult to determine the number of victims. ${ }^{15}$ Despite of this government position, nationalists still deny the massacre. Mayor of Nagoya Takashi Kawamura questioned the Nanjing massacre before a delegation from Nanjing in January 2012. He reportedly said that he thought the murder of vast numbers of civilians by Japanese troops in Nanjing "probably never happened." ${ }^{16}$ Nanjing suspended activities with Nagoya as a response to the mayor's denial. He repeated the same statement at a press conference in 2017.

When the UNESCO listed the Nanjing massacre documents nominated by the Chinese government for its Mem-

14 The Yasukuni Shrine was founded by Emperor Meiji in 1868 to enshrine about 2.5 million names of those, mostly soldiers, who died in service of the state. The names include those of the Class A war criminals convicted at the Tokyo tribunal, and that is why it's controversial for politicians to visit it in homage to the enshrined. Its museum, Shuyu$k a n$, displays the nationalist version of the Japanese war history. See: the website of Yasukuni Shrine: https://www.yasukuni.or.jp/english/ [access: 11.01.2021].

15 Ministry of Foreign Affairs, History Issues Q \& A, https://www. mofa.go.jp/policy/q_a/faq16.html.

16 Josh Chin and Yoree Koh, Chinese Outraged by Denial of Nanjing, "The Wall Street Journal", 23.02.2012. https://www.wsj.com/articles/SB 10001424052970203960804577238802680649914 [access: 11.01.2021]. 
ory of the World Register in 2015, the Japanese government was outraged. Japan considered pulling out its fund from the UNESCO, but eventually did pay its contribution of 3.85 billion yen by the end of the year.

The "comfort women" is a historical issue that invites most fierce reactions from conservatives. The Japanese military established numerous "comfort stations" during the wars in China and the Asia-Pacific (1937-1945) across the region, and recruited women, often through deception or coercion, as "comfort women". The women were confined in guarded facilities and were forced to serve soldiers one after another. Some attempted to commit suicide. After the war, they had to live with stigma in largely patriarchal societies. Survivors began to publicly talk about their suffering in 1991. Facing international outcry, the Miyazawa administration conducted a study and announced the findings in 1993 through the statement of Chief Cabinet Secretary Yohei Kono. ${ }^{17}$ Kono acknowledged that "in many cases they were recruited against their will, through coaxing, coercion, etc." and stated that the Government of Japan extends "its sincere apologies and remorse to all those, irrespective of place of origin, who suffered immeasurable pain and incurable physical and psychological wounds as comfort women". Then, the subsequent Murayama administration set up the Asian Women's Fund (AWF) that distributed "atonement money" to a number of survivors. There were also survivors who refused to receive money.

17 Ministry of Foreign Affairs, Statement by the Chief Cabinet Secretary Yohei Kono on the result of the study on the issue of "comfort women", August 4, 1993. https://www.mofa.go.jp/policy/women/fund/ state9308.html [access: 11.01.2021]. 


\section{Asahi Shimbun-bashing}

The right-wing regards the Asahi Shimbun as their archenemy. They brought three lawsuits against the newspaper in the first two months of $2015 .{ }^{18}$ The first lawsuit was filed in January collectively by 25,700 individuals under the mobilization of the National Congress to Correct the Asahi Shimbun. ${ }^{19}$ They claimed that a series of Asahi Shimbun's false reports on comfort women had severely damaged the personal right and the right to honor of the whole Japanese nation including plaintiffs and demanded that the Asahi Shimbun publicize an official apology and pay 10,000 yen (about US $\$ 83$ according to the rate at the time) to each plaintiff. The second one was filed in February by 482 individuals under the mobilization by the Association to Correct the Asahi Shimbun. They claimed that the Asahi Shimbun damaged the right to know of the plaintiffs by not correcting its article about a false testimony and continuing to report on comfort women without presenting doubts about false testimonies. The third was filed also in February by 2,557 individuals from Japan and the Unites States with the claim that the Asahi Shimbun's report on comfort women had impaired the dignity of the plaintiffs who placed the Japanese

18 For the details of the trials, see R. Kitano., especially its chapters 7, 8 and 9, pp. 165-415.

19 The group states on its website that its goal is to drive the Asahi Shimbun to the suspension of publication. The group's secretariat also serves as the secretariat for the National Congress to Correct the Historical Distortion of "the Nanjing Massacre". Both groups were set up by the Cheer Up Japan! National Action Committee. http://www.asahi-tadasukai.jp/ [access: 11.01.2021]. 
identity at the center of their personal existence. By February 2018 the Japanese courts had rejected all the requests.

They also attack individual journalists. Takashi Uemura, who wrote two articles about Kim Hak-sung, the first former "comfort woman" that publicly spoke out in 1991, became the target of an intense campaign. Harassment against him continued even after he retired from the newspaper in 2014. Accusing him of fabrication, his critics claimed that he wrongly wrote that Kim Hak-sung was taken for a Joshi Teishintai or women volunteer corps, which was a statemobilized group to support the military, to become a comfort woman. They also argued that he did not mention two important facts, that her mother sold her to a Gisaeng calloffice and that the master of the call-office or her father-inlaw then took her to the Japanese army in northern China. The difference is crucial, critics argued, because the latter did not involve any state institution, meaning that the state was not responsible for the suffering of the victims. What becomes a problem of freedom expression in this case is smear campaign against him as a person. It started in February 2014, a month before Uemura retired from the Asahi Shimbun. A popular weekly Bunshun featured an article by Tsutomu Nishioka, a professor specializing in Korea, about the "fabrication" that Takashi Uemura allegedly committed 23 years before. Two months later, well-known nationalist journalist Yoshiko Sakurai criticized Uemura in her articles. By that time Uemra had been promised a professor position by the Kobe Shoin Women's University starting in April. However, as the university received numerous threats, he was persuaded into resignation. Threats also poured in the Hokusei Gakuen University where he taught as a nonregular instructor, urging that Uemura be fired. Just after 
Uemura filed a libel suit in Tokyo against Bunshun and Tsutomu Nishioka, the university again received a letter that threatened to assault students at the entrance examination. There was also a phone call about a possible bombing at the university. ${ }^{20}$ Uemura filed another suit in Sapporo against Yoshiko Sakurai and three magazines in February. In May 2015 , one of the letters to the university even threatened to "torture him to death" and to give "divine punishments" to students. Harassment further extended to his family members. His daughter, selected to Hokkaido Prefecture's high school peace ambassador, was introduced in newspapers. The right-wing found a new target and put up her picture on internet. A message wrote, "Why don't we drive her into suicide?"21

\section{Taming experts and academics}

When Shinzo Abe made a comeback to prime ministership in December 2012, it could be well anticipated that "history wars" would become hot. In 2016, the Japanese government was again infuriated when groups in Korea, China, Japan, and some other countries jointly submitted application of "Voices of the Comfort Women" for the UNESCO Memory

20 Nyushi nerai Hokusei Gakuen daigaku ni mata kyohakujo, Tamura gakucho: konoyona hiretsuna koi yurusaenai [Another letter of threat to Hokusei Gakuen University, President Tamura: a cowardly threat like this is not tolerated], "Christian Today", 2.02.2015. https://www.christiantoday.co.jp/articles/15232/20150203/hokusei-gakuen-daigaku.htm?pc=1 [access: 11.01.2021].

21 H. Nishimura, Ianfu "netsuzo" = Asahi Shimbun kogeki ni aragau: Takashi Uemura [Resisting attacks on "fabrication" of Comfot women=Asahi Shimbun: Takashi Uemura], "Gendai no Riron”, 15.03.2015. http:// gendainoriron.jp/vol.04/serial/se01.php [access: 11.01.2021]. R. Kitano's Chapter 11 is dedicated to the lawsuits filed by Takashi Uemura. 
of the World Register. The nominated collection consisted of testimonies of former "comfort women", archives and materials related with the movement. The UNESCO's International Advisory Committee (IAC) was expected to decide on the nomination in its 2017 meeting, but it postponed the decision after the Japanese government opposed the registration. The Japanese government had proposed a "reform" that would make it possible for member states involved to block the registrations that are inconvenient for them. This new procedure was approved in April 2021, and therefore, the registration of "memories" that go against the government involved such as records of human rights violations will become impossible. It is yet to be seen whether the new procedure is applied to the application submitted before the change of the rule.

What is happening to the UNESCO Memory of the World is a spill-over case of the Abe administration's policy of removing experts in disagreement with his lines from the decision-making process. The IAC is the peak body responsible for advising UNESCO on the program and comprises 14 experts chosen for their authority in the field of the safeguarding of documentary heritage. The mechanism is designed so that decisions are made by experts from a technical point of view. The Japanese proposal is to sideline experts and place opinions of governments at the center of the decision-making.

Inside Japan, the Abe administration reportedly asked the Agency for Cultural Affairs to remove the chair of the sub-committee on the World Cultural Heritage from the Council for Cultural Affairs. The Council for Cultural Affairs, particularly its sub-committee on the World Cultural Heritage, had been responsible for selecting sites for appli- 
cation for the UNESCO World Cultural Heritage. In 2013, however, the recommendation by the Council for Cultural Affairs clashed with the idea of Prime Minister Abe. In August, the Council for Cultural Affairs recommended the Churches and Christian Heritage in the Nagasaki Region. Challenging the decision, however, the Expert Committee of Industrial Heritage of the Cabinet Secretariat recommended the Sites of Japan's Meiji Industrial Revolution. Between two conflicting recommendations, Chief Cabinet Secretary chose the Japan's industrial heritage. ${ }^{22}$ Former Administrative Vice-Minister of Education Kihei Maekawa told the media that the Prime Minister's office later pressured the Agency for Cultural Affairs to remove the chair of the subcommittee from the Council for Cultural Affairs. ${ }^{23}$

Academics have expressed their views, critical as well as supportive, on various policy issues. The Science Council, the representative organization of Japanese scientist community established in 1949 , has a duty to communicate the views of scientists to the government and the society. The Council has so far resisted the government's call on Japanese researchers to cooperate with the Ministry of Defense in developing science for military purposes. The refusal

22 The Japan's Meiji Industrial Revolution glorifies the early defense industry of modern Japan and its ideological roots. The key early proponent of the defense industry was Yoshida Shoin, a radical royalist educator who stressed "action". See http://www.japansmeijiindustrialrevolution. com/en/ [access: 11.01.2021].

23 Maekawashi ga shin-shogen, "Abe shusho kimoiri 'Meiji nihon no sangyo kakumei isan' demo gori oshi 'jinji kainyu”' [Mr. Maekawa's new account, "again an aggressive 'interference in personnel affairs' over the Sites of Meiji Japan's Industrial Revolution, a Prime Minister Abe's choice], AERAdot., 14.06.2017. https://dot.asahi.com/wa/2017061300025.html [access: 1.11.2021]. The chair of the sub-committee on the World Cultural Heritage was a professor of the University of Tokyo. He was also the chair of the Japan ICOMOS National Committee. 
was based on the Japanese scientists' own reflections on their role during the World War II. The Council released three statements to refuse research with military purposes in 1950, 1967 and 2017. The last one was the Council's response to a Ministry of Defense' new research funding program that started in 2015. Under the program, the Ministry grants funds to selected research projects that "are likely to produce results useful to the future development of defense equipment". The 2017 statement said that "this funding program has many problems due to these governmental interventions into research." ${ }^{24}$ On October 1, 2020, it became evident that Prime Minister Suga, who had just been sworn in September 16, had rejected the appointment of six scholars recommended by the Science Council as its new members. The six scholars were all from humanities and social sciences and were critical of the controversial national security bills or the Designated Secret Protection Act, both pushed by the Abe administration despite of wide protest. The Science Council is a "special organization" under the jurisdiction of the Prime Minister, operating independently from the government. Its members are public servants for special public service, ${ }^{25}$ recommended by the Council and appointed by the prime minister. ${ }^{26}$ The appointment by the prime minister, according to the previous governments' own interpretaion, was a formality and the government had to respect the nomination of members by the Council. How-

24 Science Council of Japan, Statement on Research for Military Security, March 24, 2017. http://www.scj.go.jp/en/report/index.html [access: 11.01.2021].

25 Public Servants Law, Article 2.3 (in Japanese).

26 Law on the Science Council of Japan, Article 7 and Article 17 (in Japanese). 
ever, Prime Minister Suga overturned the interpretation and explained that the "appointment" is his prerogative.

It was not the first time, however, that nominees had been rejected. In 2016, Prime Minister Abe did not accept two out of three first nominees recommended by the Council. As a result, three posts remained empty until 2017. In 2018, the Cabinet Office produced a document to confirm that the prime minister has no obligation to appoint the nominees recommended by the Council and this new interpretation got approval from the Cabinet Legislation Bureau. ${ }^{27}$ Whatever the reason behind the rejection was, the Suga administration paved the way for the government to control "the representatives of the Japanese scientist community".

\section{Shiori and cyberbullying}

Japan's notoriously large gender gap has been criticized for a long time. In 2019, Japan ranked $121^{\text {st }}$ out of the 153 countries in the rankings of the World Economic Forum's Gender Gap Index (GGI). Among the four subindexes, political empowerment was the most problematic and was $144^{\text {th }}$ in the rankings, dropped by 19 from the $125^{\text {th }}$ of the previous year. Educational attainment dropped even more drastically from $65^{\text {th }}$ of the previous year to $91^{\text {st }}$. Japan's rank in the UNDP's Gender Inequality Index (GII) for 2019 was also embarrassingly high at $23^{\text {rd }}$ out of 162 countries. $^{28}$

27 R. Miyazaki, 16-nen jinji, kantei ga nanshoku, ketsuin hoju dekizu, gakujutsu kaigi [Prime Minister's office declined on the personnel affairs of 2016, posts not filled, Science Council], "Asahi Shimbun", 4.10.2020. https://digital.asahi.com/articles/DA3S14646072.html?iref=pc_ss_date_ article [access: 11.01.2021].

28 Naikakufu Danjo Kyodo Sankaku Kyoku, Topikkusu 4: Sekai keizai 
Japanese women are generally excluded from effective participation in political, economic, social, and cultural activities. Women are also discriminated as regards access to public space for expression as well as participation in public debate. Women can speak, write, perform and create. However, they encounter different, harsh reactions in this deeply patriarchal society. The ideas that women shouldn't talk back or that women must be just obedient still remain strong, although they may not be publicly uttered because to say so is not politically correct anymore. Hostile reactions to those women who speak out with courage are narrowing public space for women to express freely and without fear, thus effectively depriving women of freedom of expression.

The experiences of freelance journalist Shiori Ito illustrates such a situation. In April 2015, she charged Noriyuki Yamaguchi, a senior TBS (Tokyo Broadcasting System Television) reporter, for a crime of rape. But the Tokyo District Public Prosecutors Office decided not to prosecute Yamaguchi in July 2016, and then the Committee for Inquest for Prosecution supported this decision in September 2017. ${ }^{29}$ Disappointed at these decisions taken in the criminal mechanism, Shiori filed a lawsuit for compensation to the damage caused by the alleged rape by Yamaguchi. In December 2019, the Tokyo District Court accepted the request of Shiori and ordered Yamaguchi to pay 3.3 million yen (ap-

foram ga "gender gap shisu" 2020 wo kohyo [Topics 4: The World Economic Forum releases the Gender Gap Index 2020], "Kyodo-Sankaku”, No. 132, March/April 2020, p. 11. https://www.gender.go.jp/public/kyodosankaku/2019/202003/202003_07.html [access: 11.01.2021].

29 The committee is comprised of 11 citizens chosen at random and examines whether the dropping of a charge by the prosecutors was right or wrong. At least 8 members must agree, if the committee demands the prosecutors to reconsider the decision (to drop the charge). 
proximately 31,000 dollars), and at the same time dismissed Yamaguchi's counter lawsuit for defamation. Yamaguchi then appealed to the Tokyo High Court in January 2020. As of mid-January 2021, the court is yet to pronounce the judgement. ${ }^{30}$

What is extraordinary in this case is that the victim spoke out publicly. It is not surprising that she received "advice" from her fellow journalists not to go public, when she decided to hold a press conference at the kisha club in the court. The "advice" shows how deeply the resistance to a victim of sexual violence speaking out is rooted in the society. A friend journalist said to her, "If you have a press conference at the court's kisha club, none of the reporters there will write. It will only hurt you. You had better stop." Another fellow journalist informed her that government officials were persuading media not to write about her case. ${ }^{31}$

However, because this was a very rare case, she soon became a symbol of the \#MeToo movement in Japan. Bashing against her was also very severe. Internet users used words

30 There are numerous news reports on the case of Shiori. BBC Two provides a detailed account by herself. Japan's Secret Shame, "BBC Two" 28.06.2018. https://www.bbc.co.uk/programmes/b0b8cfcj [access: 11.01.2021]. Its written story is Japan's Secret Shame. Shiori Ito: Japan's attitudes to allegations of sexual violence are locked in the past, "BBC Two", 28.06.2018. https://www.bbc.co.uk/programmes/articles/3z44Njyr5wzm3wbVMGZ7tFr/shiori-ito-japan-s-attitudes-to-allegations-ofsexual-violence-are-locked-in-the-past [access: 11.01.2021]. She published her account as a book, Black Box, in Japanese in 2017. A bilingual hour-long video footage of her press conference at the Foreign Correspondents' Club of Japan (FCCJ) on December 18, 2019 is available at YouTube. https://www.youtube.com/watch?v=PBCl8Ggp4MY [access: 11.01.2021]. On the same day, the defendant, Noriyuki Yamaguchi, also held a press conference at the FCCJ. Available at https://www.youtube. com/watch? $\mathrm{v}=\mathrm{m} 2 \mathrm{kNfLGjp-A}$ [access: 11.01.2021].

31 Ito S., p. 224. 
such as "prostitute", "honey trap", or "go back to Korea." Photos of her family were put on the Internet and her sister's face was exposed. Chiki Ogiue, who conducted research on the cyberbullying against Shiori, found approximately 70,000 posts on her and selected about 3,000 that could be considered as defamation. As to the pattern of cyberbullying, he explained that there is an "opinion leader" as a model whose discourse is copied by other users. ${ }^{33}$ In June 2020, Shiori filed a suit against manga artist Toshiko Hasumi for posting an illustration with the phrase, "The complete failure of a pillow operation (meaning 'seduction')" and against two others for retweeting it. In August, she filed a suit against lawmaker Mio Sugita (LDP) about pressing "like" for the Twitter postings that insulted her with phrases like "the failure of a pillow operation" and "honey trap", and filed another against Shohei Osawa, a former specially appointed associate professor at the University of Tokyo, over defamation on Twitter.

There is complex background to the case of Shiori. Yamaguchi was the chief of the TBS Washington Bureau when Shiori met him and was seen very close to Prime Minister Abe. Yamaguchi later wrote two books on Abe. Shiori writes that a male police officer who heard her account strongly advised her to drop the charge because the man she was accusing was "powerful and influential". ${ }^{34}$ She was also told

32 In Japan there is severe, sometimes violent, discrimination against Koreans. Saori is Japanese but this phrase was used to threaten her.

33 SNS ga kiba wo mukutoki: Matsuya Soichiro-san, Ogiue Chiki-san, Shida Yoko-san [When SNS attacks: Mr. Soichiro Matsuya, Mr. Chiki Ogiue, Ms. Yoko Shida], "Asahi Shimbun”, 1.07.2020.

34 Japan's Secret Shame. Shiori Ito: Japan's attitudes to allegations of sexual violence are locked in the past, "BBC Two", 28.06.2018. 
that her "career as a journalist would probably come to an end" if she insisted on making those allegations. ${ }^{35}$ Lawmaker Mio Sugita is a nationalist LDP politician very close to Shinzo Abe, and Toshiko Hasumi is a manga artist who works around far-right themes. Mio Sugita recently caused an uproar when she said "Women can tell lies at any time" at a meeting referring to the topic of sexual violence. Toshiko Hasumi is globally known for her controversial illustration that depicted a Syrian girl with the caption, "I want to live a safe and clean life, eat gourmet food, go out, wear pretty things, and live a luxurious life ... all at the expense of someone else. I have an idea. I'll become a refugee."36 The illustration was problematic also because it was based on a picture of a six-year-old girl in a refugee camp in Lebanon taken by Jonathan Hyams, a photographer working for Save the Children. ${ }^{37}$ Both Mio Sugita and Toshiko Hasumi are actively involved in the anti-comfort women campaign.

The case of Shiori is only the tip of the iceberg. According to the government's White Book on Gender Equality 2020, the Cabinet Office's survey on violence between men and women in 2017 shows that $7.8 \%$ of the women have an experience of forced sexual relation and that $58.9 \%$ of the victims never reported to or consulted with anyone and that only $2.8 \%$ of the victims reported to the police. ${ }^{38}$ The

35 Ibidem.

36 Is this manga cartoon of a six-year-old Syrian girl racist? "BBC News", 8.10.2015. https://www.bbc.com/news/blogs-trending-34460325 [access: 11.01.2021].

37 Ibidem.

38 See Naikakufu Danjo Kyodo Sankaku Kyoku, Chapter 6, Section 2. https://www.gender.go.jp/about_danjo/whitepaper/r02/zentai/html/honpen/b1_s06_02.html [access: 11.012021]. 
US State Department's Human Rights Country Report 2019 writes that in Japan "[r] ape and domestic violence are significantly underreported crimes", and that "[o]bservers attributed women's reluctance to report rape to a variety of factors, including the fear of being blamed, fear of public shaming, a lack of victim support, potential secondary victimization through the police response, and court proceedings that lacked empathy for rape victims." 39 All these observations indicate that the problem is structural. The freedom of expression of the victims of sexual violence is severely undermined by the lack of policies of the government and attacks of the invigorated right-wing activists.

\section{The future of the freedom of expression in Japan?}

The constitution guarantees the freedom of thought and conscience (Article 19), the freedom of religion (Article 20), the freedom of assembly and association, as well as speech, press and all other forms of expression (Article 21), and academic freedom (Article 23). The LDP draft constitution for future Japan guarantees all these freedoms nominally, but the practices of successive LDP administrations indicate that it is quite uncertain how much these freedoms will be actually respected. The draft constitution adds the following clause to Article 21 on the freedom of expression.

2. In spite of the previous clause, it is not permitted to conduct activities that aim to harm public interest or public order or to establish a group with such a purpose.

39 Unites States Department of State, Bureau of Democracy, Human Rights, and Labor, 2019 Country Reports on Human Rights Practices: Japan. https://www.state.gov/reports/2019-country-reports-on-human-rights-practices/japan/ [access: 11.01.2021]. 
Activities that can harm public interest or public order can be interpreted in many different ways. How about peaceful activities that challenge what the government thinks is national interest? How about expressions that question what the government thinks is public order? If worst comes to worst, it will lead to the birth of another authoritarian state in Asia. Fear for the uncertain future of East Asia is a factor behind the aspirations for the return to a nationalist and authoritarian state system in Japan.

\section{Bibliography}

Naikakufu Danjo Kyodo Sankaku Kyoku (Gender Equality Bureau Cabinet Office), 男女共同参画白書 [Danjo kyodo sankaku hakusho, Reiwa 2-nen ban], Tokyo 2019. https://www.gender.go.jp/about_danjo/whitepaper/r02/ zentai/html/honpen/b1_s06_02.html.

Goodman C.F., “Contemplated Amendments to Japan's 1947 Constitution: A Return to Iye, Kokutai and the Meiji State", Washington International Law Journal, Vol. 26, No. 1 (Special Issue on the Japanese Constitution), 2017. Hamada T., "Contested Memories of the Imperial Sun: History Textbook Controversy in Japan", American Asian Review, Vol. XX, No. 4, 2002.

Ito S., ブラックボックス [Black Box], Tokyo 2017.

Jiyu Minshu To (Liberal Democratic Party), 日本国憲法改

正草案 [Nihonkoku Kenpo Kaisei Soan], 2012.

Kingston, J., "Watchdog journalism in Japan Rebounds but Still Compromised", Journal of Asian Studies, Vol. 77, No. 4 (November), 18.

Kitano R., 朝日新聞の慰安婦報道と裁判 [Asahi shimbun no ianfu hodo to saiban], Tokyo 2020. 
Nishimura H., “慰安婦＝「捏造」=朝日新聞攻撃に抗う ～植村隆” [Ianfu “netsuzo" = Asahi Shimbun kogeki ni aragau: Takashi Uemura], 現代の理論 [Gendai no riron], March 15, 2015, http://gendainoriron.jp/vol.04/serial/ se01.php.

NGO Coalition for Free Expression \& Open Information in Japan (NCFOJ), Joint NGO Report on the International Covenant on Civil \& Political Rights (ICCPR) Article 18, 19 \& 21, Part I: Freedom of Expression, Freedom of the Press, Freedom of Assembly, and Right to Know, September 30, 2020. https://sites.google.com/view/ncfoj.

Report of the Working Group on the Universal Periodic Review, Japan, Human Rights Council, 4 January 2018, A/HRC/ $37 / 15$.

Report of the Special Rapporteur on the promotion and protection of the right to freedom of opinion and expression on his mission to Japan, 15 June 2017, A/HRC/35/22/ Add. 1

Yamazaki M., 歴史戦と思想戦一歴史問題の読み解き方 [Rekisisen to shisosen: rekishi mondai no yomitokikata], Tokyo 2019.

\begin{abstract}
This article analyzes the decline of the freedom of expression in Japan during the past decade. I argue that the decline is the result of increased political interference from the nationalist conservative administration and intensified campaigns by those who ally with it, including its anonymous supporters who blackmail media or individuals. Although physical attacks such as assassinations have become rare in the past decade, threats and blackmail have continued. The fear is real as memories of political violence such as assassination are still fresh. The broadcasters are particularly vulnerable because
\end{abstract}


there is legal basis for politicians to interfere in the program editing, namely Article 4 of the Broadcast Act, a point raised at the Human Rights Council. Political interference is also institutionalized in the school textbook screening, and in the restriction of passports for journalists traveling to conflict zones. Cases of freedom of expression revolve around two inter-related themes, Japan's wartime atrocities and post-war pacifism. Media, journalists, academics, and activists who write critically about wartime atrocities, such as the Nanjing massacre or comfort women, or those who speak against legislation, such as the latest security bills and the secret protection act that may undermine the constitutional pacifism, receive various forms of pressure, including removal from influential posts, harassment, threats, or blackmail. Pressure is also exerted on their families. Finally, the article examines how the freedom of expression for women is severely undermined by cyberbulling.

Keywords: Japan, freedom of expression, wartime atrocities, comfort women, pacifism, Asahi Shimbun, Saori 


\author{
Ied Veda Sitepu, Lisa G. Kailola, Dikky Antonius \\ Faculty of Literature and Language, Education Management \\ Graduate Program, Faculty of Engineering, \\ Universitas Kristen Indonesia
}

\title{
Right to Education: Revisiting Access for Students with Disabilities to Higher Education in Indonesia
}

Education promotes equality and lifts people out of poverty. It teaches children how to become good citizens. Education is not just for a privileged few, it is for everyone. It is a fundamental human right. ${ }^{1}$

(Ban Ki-moon)

\section{Introduction}

The United Nations describes human rights as "[...] inherent to all human beings, regardless of race, sex, nationality, ethnicity, language, religion, or any other status. Human rights include the right to life and liberty, freedom from slavery and torture, freedom of opinion and expression, the right to work and education, and many more. Everyone is entitled to these rights, without discrimination."2 People, however, are

1 UN Secretary-General Ban Ki-moon's speech during his visit to Timor-Leste, https://www.unicef.org/media/media_65935.html [access: 26.02.2021].

2 Human Rights. Peace, dignity and equality on a healthy planet. UN at https://www.un.org/en/sections/issues-depth/human-rights/ [access: 18.12.2020]. 
attracted to human rights issues when it concerns with violations at war, social injustice and gender discrimination. Issues concerning lack of education or access do not come to surface as all countries have given at least education to their citizens, regardless of quality, In this chapter, we are going to discuss people's ignorance of the rights of people with disabilities despite the fact that "between $4 \%$ and $11 \%$ of the Indonesian population are affected by a disability that limits their ability to participate in society." 3 This paper will discuss access of people with disabilities to higher education, from several aspects, such as cultural and gender regardless of all regulations and laws that states that every citizen of the Republic of Indonesia has a right to education, particularly the nine year education (primary and junior secondary levels), ${ }^{4}$ the social, economic and cultural aspects which are the major factors that hinder PWD to education in general and higher education in particular. The portrait of higher education in Indonesia will also be highlighted to give a better picture.

\section{International Regulations That Guarantee Every Human Right To Get An Education}

In international regulations, we can also find articles that require the implementation of education, such as:

3 Disability in Indonesia: What Can We Learn from the Data? https://www.monash.edu/_data/assets/pdf_file/0003/ 1107138/Disability-in-Indonesia.pdf [access: 18.12.2020].

41945 Constitution, Chapter 31 and Law Num 20/2003, Article 6(1): "Every citizen from the age of 7 to 15 has the right to primary education" ( translation by the author), https://www.mkri.id/public/content/infoumum/regulation/pdf/UUD45\%20ASLI.pdf [access: 18.12.2020]. 
1. Universal Declaration of Human Rights ${ }^{5}$

Article 26 paragraph (1): "Everyone has the right to education. Education should be free, at least for the lower levels of school and primary education. Low education must be required." Technical and vocational education in general should be open to all, and higher education should be accessible to all in the same way, on the basis of merit.

Whereas in the Universal Declaration of Human Rights which was declared by the UN General Assembly on December 10,1948, it is also necessary to include the idea of free education for education participants at low and basic levels.

2. International Covenant on Economic, Social and Cultural Rights $^{6}$

Article 13 paragraph (1): „States parties to this covenant recognize the right of everyone to education." They agreed that education should be directed towards the development of the whole human personality and awareness of his selfworth and strengthening respect for human rights and fundamental human freedoms. They further agreed that education should enable all people to participate effectively in a free society, promote mutual understanding, tolerance and friendship between nations and all groups, races, ethnicities or religions, and further promote the activities of the United Nations to nurture peace. Whereas in the covenant which was enacted on December 16, 1966 and came into

5 Universal Declaration of Human Rights, Article 26 [access: 18.12.2020].

6 International Covenant on Economic, Social and Cultural Rights. https://www.ohchr.org/EN/ProfessionalInterest/Pages/CESCR.aspx [access: 14.01 .2021$]$. 
effect on January 3, 1976, it was recognized that the rights of everyone to obtain education and the participation of the community were recognized.

3. International Covenant on Economic, Social and Cultural Rights $^{7}$

Article 13 paragraph (2) letter a: "The state parties to this covenant recognize that in order to fully exercise this right: a. Basic education must be compulsory and freely available to all".

Thus, this covenant includes efforts to provide free education at the basic education level. International regulations governing education exist after Indonesia made the 1945 Constitution, so before the United Nations declared the Universal Declaration of Human Rights or the Universal Declaration of Human Rights, the Indonesian state actually had its own thoughts that every citizen had the right to receive it as stated in Article 31 paragraph (1) and (2) of the 1945 Constitution prior to amendment.

\section{Access to Higher Education in Indonesia}

It is true for all countries in the world that every citizen will need education because whether they realize it or not, education is the real measure of the country's welfare. With good education, people will be prosperous, it can protect and fulfill all the needs of its citizens both in fulfilling primary needs (clothing, food, shelter), secondary needs and tertiary needs. In developed countries, which are marked by the quality of educational outcomes, the welfare is viv-

7 Ibidem. 
idly seen compared to that of developing or underdeveloped (poor) countries. Indonesia, which gained its independence in August 17, 1945, is still categorized as a developing country. Compared to its neighbouring countries in ASEAN, Indonesia's GDP/capita is still number 5, after Singapore (1), Brunei (2), Malaysia (3) and Thailand (4). ${ }^{8}$

The government has realized the importance of education, so education became the primary attention and with the realization of the allocation of education funds (as outlined in Article 31 paragraph (4) of the 1945 Constitution), although it is difficult for the government to balance its constitutional obligations in fulfilling the education budget amid the high burden of principal installments and debt interest in the state budget, which is still very large.

To date, Indonesia has around 4,670 higher education institutions, ${ }^{9}$ consisting of universities, academies, vocational institutes, state and private entities which spread from Sabang in the most western part to Merauke the most eastern part of Indonesia. The denser the population, the higher the number of institutions. Jakarta, the capital city, Special Region of Yogyakarta, Central Java and East Java are among the provinces with the highest number of institutitons. Indonesian students access higher education after a total of approximately 12 years studying at primary, junior secondary (Sekolah Menengah Tingkat Pertama) and senior secondary school (Sekolah Menengah Tingkat Atas), from the

8 Tradingnomics's Quarter 3-2020 data (List of ASEAN countries by GDP - Wikipedia) - https://en.wikipedia.org/wiki/Economy_of_Indonesia [access: 18.01.2021].

9 Ministry of Research, Technology and Higher Education. Data and Information Centre for Science, Technology and Higher Education, 2018, https://pddikti.kemdikbud.go.id/asset/data/publikasi/Statistik\%20Pendidikan\%20Tinggi\%20Indonesia\%202018.pdf [access: 18.01.2020]. 
age of six or seven to the age of 17 or 18 . At the tertiary level, there are three levels of graduates following the general terms in higher education i.e. undergraduate, the first stage of HE level, three-six year of studies, depending on the area of study, and leads to the award of the Bachelor's degree (Sarjana or S1), graduate degree, the second stage, for another two to three years, depending on the area of study, and leads to the award of the Master's degree (Magister or S2) and post-graduate. The third stage that can last around three years, depending on the area of study and leads to the award of the Ph.D. or Doctoral degree (Doktor or S3). The Indonesian Qualification Framework dictates that there are two streams of obtaining the degrees, first the vocational line and another in the academic line. Both may go up to the third stage, but with different purposes.

Minister of Education and Culture's decree Number 46/2014 clearly states about special education, special services and/or special teaching and learning in higher education, which determines higher education institution's responsibilities to admit people with disabilities to learning process and all activities until they graduate. This is a clear statement from the government that no institution is allowed to reject students with disabilities as long as they can facilitate their activities. $^{10}$

The higher education stage is important before one enters the labour market. It is the phase when one prepares with competencies that are required by industry. Higher

10 Permendikbud No 46, Tahun 2014 tentang Pendidikan Khusus, Pendidikan Layanan Khusus dan/atau Pembelajaran Khusus pada Pendidikan Tinggi (Minister of Education and Culture's Decree Number 46/2014 on Special Education, Special Service Education and/or Special Learning in Higher Education. 
education institutions nowadays not only serve as the place for the development of knowledge and technologies, but also a place to prepare future workforce. Tertiary degrees can also be seen as a stepping stone to the future:

A degree may once have been a passport into graduate employment: it was indicative of the level of knowledge and intellectual ability. However, as a result of organisational changes and the expansion in the numbers of graduates, this is no longer the case. Although graduate jobs are expanding, so is the supply of graduates. In addition, many employers are also looking for various types of experience. Hence a degree is no guarantee of a job, let alone a career, and should only be seen as reaching 'firstbase' in the recruitment process. ${ }^{11}$

The 2019National Labour Force Survey concerning Indonesia's workforce statisticsm reported that there were 8.13 million of people who were underemployed (people working under 35 hours/week and are still searching for a job or nor willing to take another job) ${ }^{12}$. This figure, however, does not define whether this includes the number of those with disabilities and whether they have equal access to employment. Everything concerning labour market opportunities is a general picture. For instance, the World Bank in Indonesia Jobs Report. Towards Better Jobs and Security for All (2010) states that employers hired more workers with more competencies compared to the past due to more severe competitions in the market. This only shows what employers want

11 L. Harvey, 2000, New Realities: The relationship between higher education and employment, Tertiary Education and Management 6: 3-17, Netherlands.

12 Sakernas 2019. Agustus 2019: Tingkat Pengangguran Terbuka (TPT) sebesar 5,28 Persen (National Labour Force Survey 2019. August 2019: Open Unemployment Rate is 5.28 Percent), https://www.bps.go.id/ pressrelease/2019/ [access: 18.01.2021]. 
of their future employees without any specific statement that perhaps more women are needed or how many percent more they want women to be in their workforce or whether or not disabilities are included in recruitment. Fair Observer reports that nearly $70 \%$ of disabled children do not go to school and they only have $66.8 \%$ chance of finishing primary education. This is a sad figure considering that, with disabilities, their access is limited and this eventually impacts their future employment. The report states that only $64.9 \%$ of people with disabilities has a chance of getting a job. ${ }^{13}$ Furthermore, according to the report,

...the vast gap that exists between those with disabilities and those without is actually created not only because of the physical limitations of the disabled, but also due to the immature mindsets of the public and their inability to embrace diversity. However, it is often because these people look "different" and have distinctive mannerisms that the non-disabled refer to their actions as irregular and abnormal. ${ }^{14}$

\section{Cultural and Gender Issues}

From the west to the east, Indonesia is indeed a land of diversity in many aspects, hundreds of local languages and diverse socioeconomic backgrounds. Disparity between provinces in Indonesia does exist, for example, education facilities available in some regions are not available in oth-

13 https://www.fairobserver.com/ [access: 18.01.2021].

14 M.Z. Rakhmat, D. Tarahita, 2017, Disabled Workers in Indonesia Must Be Respected, https://www.fairobserver.com/region/asia_pacific/ indonesia-disabled-rights-asian-world-international-news-34450/ [access: 18.01 .2021$]$. 
ers. Indonesia is a multicultural country with hundreds of ethnic groups. Each ethnic group is governed by its own rules or norms which are established to protect the group and meant for their continuity and sustainability, and more often than not, they are implied differently for their male and female members. They also affect many aspects, like education for example. There is also a belief that women should be dependent on men who will become breadwinner of the family; this is also the reason why the culture favors boys over girls when it comes to education. Alhough the government has declared nine-year education-elementary and junior secondary levels-free for everyone, there are still parts of Indonesia where not only the quality of education is the challenge, but also the equality of opportunities of boys and girls in schools. ${ }^{15}$ Indonesia is left behind in HDI ranks, even in Asia. The 2010 Human Development Report (HDR) ranked Indonesia 108 out of 182 countries according to the Human Development Index (HDI). This measurement does not include the degree of gender equality and Indonesia still faces challenges in achieving gender equality in all key development indicators. ${ }^{16}$ Gender disparities, for example, still exist in many provinces in Indonesia, be it in primary, secondary and teriary levels. Their access to education is limited as long as cultural and gender aspects are concerned. For example in In NTT Province, boys are prioritized for education over girls and girls are not allowed to go to school because a girl's impurity will be questioned

15 Kementerian Pemberdayaan Perempuan dan Perlindungan Anak (Minstry of Women Empowerment and Child Protection) POLICY BRIEF. GENDER EQUALITY. INDONESIA. At https://www.kemenpppa.go.id/lib/uploads/list/eec77-buku-policy-brief-gender-equality.pdf [access: 20.01.2021].

16 Ibidem. 
and her bride price will go down when she goes to a school outside her area of living. ${ }^{17}$

Concerning people with disability, each ethnic group has their own belief in dealing with them. The lack of education also makes matter worse. The member of the family with disability will suffer from estrangement or is considered non-existent. They play important roles, especially when we talk about sustainable development-development without any exclusion. This means that the existence of people with disabilities can no longer be ignored. They are part of the society and the society is responsible to acknowledge their existence as part of them and their wellfare should also be part of the society's responsibility. People with disabilities are all around us. Their existence is denied because of cultural aspects. The family with disabled members will try their best to hide the poor member(s) only because they do not want to be judged as an unfortunate family or to be exact, cursed family. There are stories how these unfortunate members were hidden or even imprisoned in a small room so that they would not escape or bring embarassment to the whole family. Girls with disability, furthermore, experience double discrimination. Thus, in general, as discussed above, women are subjected to cultural disadvantage, which makes it difficult to take part in the community life. Their disability, will make things worse. SDG Number 5 calls for our attention. Gender equality means that it focuses on the empowerment of women and girls so that they will get similar opportunities as their male counterparts. Disabled women's chance to obtain education is lower than that of men's; therefore, they will have no competence and be less

17 Ibidem, p. 3. 
likely to be employed. ${ }^{18}$

\section{Access Denied to Higher Education?}

Why are so many children with disabilities not in schools? First, it is difficult to get enrolled - and even those who do so are often asked to leave later due to many reasons. Despite legal obligations, domestic regulations do not mandate adequate support for mainstream schools to teach students with disabilities. In mainstream schools, there is no specific training for teachers and principals, there is the lack of funding and no support staff. It creates a concept of thinking in the society that parents or families must provide the support. Some children's disability is so high that they have to be home-schooled by their parents. As a consequence, often only those with mild disabilities manage to enroll and stay in mainstream schools. Only less than 10 percent of children with special need receive formal education in Indonesia. ${ }^{19}$

These students face additional difficulties if they try to pursue higher education. Mostly in private universities, there is no specific guideline mentioned that candidates with disability couldn't enroll to university. Usually, all university candidates go through a medical test as part of enrolment if they want to study certain fields. Official guidelines allow universities to deny entry to students with certain

18 European Women Lobby. Women more prone to disability than men, and particularly vulnerable to discrimination and violence https://www.womenlobby.org/Women-more-prone-to-disability-than-men-and-particularly-vulnerable-to [access: 18.01.2021].

19 Coulson, Jonthon. Education and exclusion for special needs students in Indonesia. Institute of Current World Affairs. At https://www. Icwa.org/special-needs-education-indonesia-extraordinary-schools-ordinary-people/ [access: 18.01.2021]. 
physical or psychological disorders declared or discovered in the test - even if the disability in question has no bearing on the chosen subject. For example, people with hearing impairments are advised not to study more than a dozen subjects, including law and foreign languages. Fearing rejection based on their disabilities, many students choose to only pursue the approved subjects instead. It is understandable when a specific ability (like physical ability) needed by certain study programs. ${ }^{20}$

The candidates with disability usually choose short-term programmes, such as two or three-year diploma to get certified before they come into the marketplace/job. Therefore, they will go to vocational education or try to obtain certain vocational competency that will make them independent. ${ }^{21}$ It is clear that higher education can only be accessed by a small number of students with disabilities, although many universities declare that they are ready to welcome them. In order to open themselves to the disabled, institutions must not only prepare infrastructure, but also provide lecturers with knowledge of disabilities and skills to deal with them. These are important because the types and spectrum of disabilities vary. In the special education system, students are divided according the to type of disability - a school for

20 University of Ottawa. Understanding Barriers to Accessibility. https://www.uottawa.ca/respect/sites/www.uottawa.ca.respect/ files/accessibility-cou-understanding-barriers-2013-06.pdf [access: 18.01.2021].

21 Kemensos Perluas Akses Penyandang Disabilitas terhadap Dunia Kerja Lewat Program Penjangkauan (the Ministry of Social Affairs Expands Access for Persons with Disabilities to the World of Work through Outreach Programs, https://www.jpnn.com/news/kemensos-perluas-akses-penyandang-disabilitas-terhadap-dunia-kerja-lewat-program-penjangkauan https://www.jpnn.com/news/kemensos-perluas-akses-penyandang-disabilitas-terhadap-dunia-kerja-lewat-program-penjangkauan [access: 18.12.2020]. 
the blind is not going to be useful for a child with hearing impairments, and few schools accept those with autism and other disabilities outside the official categories. For many families, the mainstream schools are likely to be their only option. But when those schools reject the children, there is nowhere else to turn.

The government has begun to recognize some of these problems and responded by amending the regulations on the education of people with disabilities. But those revisions do not remove the main obstacles to mainstream education for these children. It needs collaboration with universities and organizations to do research and solve these problems as well.

When education for children with disabilities is concerned, the government has mandated right to education: ${ }^{22}$

Setiap anak yang cacat fisik dan atau mental berhak memperoleh perawatan, pendidikan, pelatihan, dan bantuan khusus atas biaya negara, untuk menjamin kehidupannya sesuai dengan martabat kemanusiaan, meningkatkan diri, dan kemampuan berpartisipasi dalam kehidupan masyarakat dan bernegara (Children with physical and or mental disabilities have the right to care, education, training, and special assistance and it is at state expense, to guarantee their lives in accordance with human dignity, to develop themselves and to improve their abilities to participate in the society and the state).

However, in reality only a small number of higher education insstitutions in the countries are open to people with disabilities. Ministrial Decree Number 70/2009 defines students with disabilities into 10 categories, ie. a. blind; b. deaf; c. speech impaired; d. mentally disabled; e. quadriplegic;

22 Undang-undang No 39 Tahun 1999 tentang Hak Azasi Manusia (Law Number 39/1999 on human rights). 
f. unsociable; g. difficulty learning; h. slow to learn; i. autism; j. motoric problems; $k$. being a victim of drug abuse, illegal drugs, and other addictive substances; l. other disorders; m. multiple handicap. ${ }^{23}$

Indeed, the country has given attention to students with disabilities, proven by the existence of schools for the special need children, but this is not enough. People with disabilities are restricted not only by their in capacities, but also by social or cultural barriers. The Gross Enrollment Rate to higher education in Indonesia is $30,85,{ }^{24}$ but there is no further information on how many people with disabilities are at the tertiary level. The calculation of students with disabilities concerns the primary level and it is still in progress. ${ }^{25}$ The calculation of those in higher education level is still yet to be done. The 91,000 primary and secondary level students in inclusive education institution have to be considered to go into higher education. With the large spectrum of disabilities, we cannot just ignore their access to higher education. Better training will guarantee their future and secure financial independence and also their dignity and, thus, less burden to the society. Let us take Finland as an example of a country that has give better attention to people with disabilities, following the Disability Policy 2006-2015. Finnish higher education therefore confirms that "the essential aim of inclusive higher

23 Undang-undang No. 70 Tahun 2009 tentang Pendidikan Inklusif bagi Peserta Didik yang Memiliki Kelainan dan Memiliki Potensi Kecerdasan (Law Number 70/2009 on Inclusive Education for Students with Disabilities and Disclosure and Potential Intelligence) Art. 3.

24 Statistik Nasional Tahun 2020 (2020 National statistic) at https:// www.bps.go.id/ [access: 18.01.2021].

25 https://www.kemdikbud.go.id/main/blog/2019/11/ayo-dukung-percepatan-pendataan-siswa-penyandang-disabilitas-di-sekolah-inklusif [access: 18.01.2021]. 
education is to grant physical, psychological, and social accessibility in teaching and learning in Finnish higher education institutions (HEIs), so that everyone has the same right and access to study regardless of one's characteristics." 26

Furthermore, they believe that accessibility is an investment and that "accessible and barrier-free learning environment must be considered as a strategic and long term operation on all levels of the higher education community." ${ }^{27}$

Thus, when access to education is a person's right, it is important to include tertiary education into consideration as well. Higher education is no longer a place to develop knowledge and technology, it has become a training institutions for people to better prepare for the future.

\section{Welcoming POW to the Campus}

Education system in Indonesia has been already made and designed for every citizen in Indonesia. ${ }^{28}$ The regulation in Indonesia already covered disability system. ${ }^{29}$ Therefore, the country has already provided education for disabled citizens.

However, the education system itself consists of many important elements, all of which function to guarantee the

26 Karhu, Markku, „Accessible and Inclusive Studying at Higher Education Institutions in Finland“ VI Congreso Internacional sobre Aplicación de Tecnologías de la Información y Comunicaciones Avanzadas (ATICA2014).

27 Ibidem, p. 103.

28 Undang-undang No 20 Tahun 2003 tentang Sistem Pendidikan Nasional (Law Number 20/2003 about National Education System).

29 Undang-undang No 8 Tahun 2016 tentang Penyandang Disabilitas (Law Number 8/ 2016 on People with Disabilities). 
output of the system (i.e. graduates) projected as designed before - accompanying each uniqueness. In order to produce graduates with competencies or quality graduates, education itself needs infrastructure to support and enhance the system.

Figure 1. Education support system and infrastructure

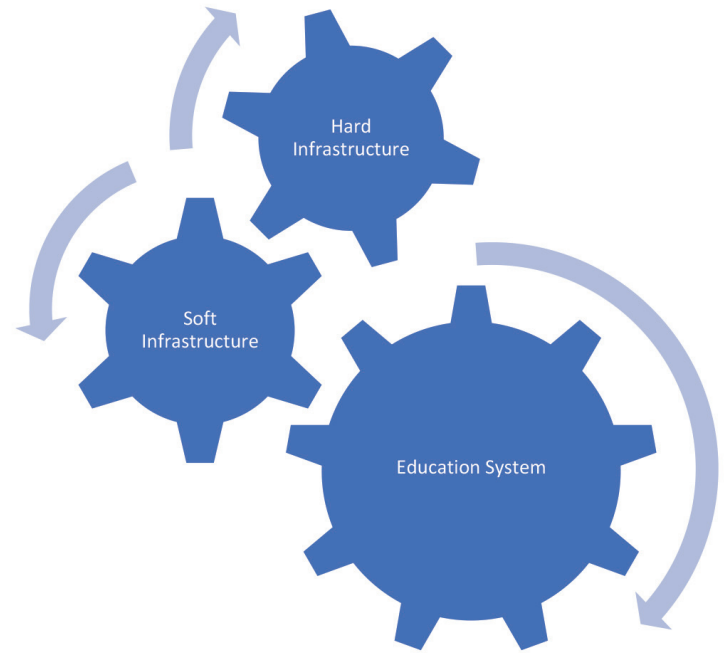

Source: (Cook M., Salazar L., 2016), p. 3.

The infrastructure itself consists of soft infrastructure and hard infrastructure. Soft infrastructure is usually related to equipment or tools which cannot be seen and which function to support the education system such, as course materials, computer software, academic information system, counselor facility, etc. Hard infrastructure is usually related to equipment or tools which can be seen and which support the education system such as building, computer, books, etc. 
The infrastructure is manifested from the education system requirement. The education system in each university will be different according to their specific. Therefore, the infrastructure of each university will be different. Usually, these systems will encourage/motivate all students in Indonesia to take higher education. Usually, all systems will be their marketing strategy to promote their university. Moreover, all of the systems - which related to infrastructure will guarantee all of the students to work for their future.

However, when disability students is concerned, infrastructure has to be adjusted to their needs. Not many institutions of higher learning are ready to welcome students with disabilities, since infrastructure will be costly. Hard infrastructure for disability students such as rampways, wheel chairs, elevator, disability toilets may by easily provided, but it will be difficult to ensure Braille language facilities everywhere. To date, infrastructure for students with disabilities is rarely found in higher education institutions.

Figure 2. Hard Infrastructure for disabled students

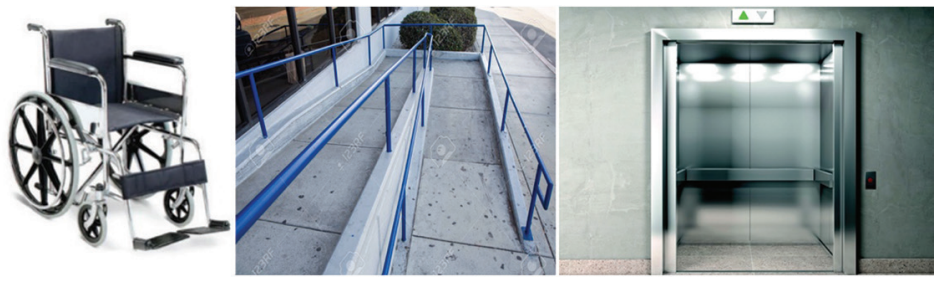

Source: A private archive of the authors.

Soft Infrastructure for disability students is to be provided too. Counselling facilities, students guidance, software for disabled students, etc. are even harder provided by university. Moreover, there are no regulations that de- 
termine the minimum infrastructure for the disability student. Therefore, up to free every university to determine the equipment for disabled students according to their own understandings. On the other hand, all the facilities and infrastructure promoted are usually for students without disabilities. Therefore, all of these promotions will be actually discouraging to disability students. They have already been rejected before they even registered because of this promotions. Disability students are already discouraged right before they registered because they found no facilities provided for them in promotion. Therefore, it is very important to complement the infrastructure in universities for disability students included in the. Infrastructure functionsas support for the educational system itself.

Therefore, it is important to interpret minimum infrastructure for disability students and the goal of each department will be necessary. Questions to interpret the accessibility for disability students table below are necessary to complete the interpretation of the infrastructure:

Having analyzed the responses to the questionnaire, we can define what will be necessary to complete the infrastructure in the universities

Table 1. Questions of infrastructure interpretation ${ }^{30}$

\begin{tabular}{|l|l|l|}
\hline \multicolumn{1}{|c|}{ Question } & \multicolumn{1}{|c|}{ Answer } & Note \\
\hline $\begin{array}{l}\text { Is there any career/job position for disability student in this de- } \\
\text { partment? }\end{array}$ & & \\
\hline What percentage of RPS may be accessed by disability student? & & \\
\hline What kind of information is dominant in this department? & Visual/Audio & \\
\hline What percentage of courses is necessary for phsycomotoric? & & \\
\hline What kind of material courses are provided in this department? & & \\
\hline Is there any disability group made for this department? & & \\
\hline
\end{tabular}

30 I.V. Sitepu, L.G. Kailola, D.A. Hutauruk, 2020, Preliminary report on ALIGN Project, Indonesia Case Study (Unpublished) 
Is there any staff responsible for communication disability matters?

What kind of disability would be impossible in to handle in these department?

Source: A private archive of the authors.

Table 2. Availability of infrastructure and facility ${ }^{31}$

\begin{tabular}{|l|l|l|}
\hline \multicolumn{1}{|c|}{ Infrastructure } & \multicolumn{1}{c|}{ Minimum } & Complementary \\
\hline \multicolumn{2}{|c|}{ Admission } & \\
\hline Registration website for disability & \multicolumn{2}{|l|}{} \\
\hline Universities guide for disability & \\
\hline \multicolumn{2}{|c|}{ Learning Process } & \\
\hline Rampway & & \\
\hline Toilet & & \\
\hline Wheelchair & & \\
\hline Canteen & & \\
\hline Brailebook & & \\
\hline Software for disability & & \\
\hline Elevator & & \\
\hline Sport & & \\
\hline Study Group & & \\
\hline Worship Groups & & \\
\hline Counselors & & \\
\hline Staff & & \\
\hline Lecturer & & \\
\hline
\end{tabular}

Source: A private archive of the authors.

After having this form completed, universities can meet all the minimum requirement for the universities for disabled students.

\section{Conclusion}

It is clear that most countries, both developing or developed ones, have their own regulations to guarantee that all of their citizens - including disability student s- get the

31 Ibidem. 
same right and access to education, a primary, secondary and tertiary levels. Students with disability are rarely found in higher education because Indonesian institutions are not prepared to meet disability students' needs concerning the enrollment system, clear guidelines for disability, staff or lecturers who are well aware and competent with the ability to communicate and care. Infrastructure in universities should also be prepared to welcome them into campus and its facilities. Therefore, they are denied before they even register to the universities. To prepare higher education institutions for disability students, universities - especially department and student service units - have to interpret all of their boundaries and readiness for disability: the outcome of education for students with disabilities and prospective workplaces, curricula which include knowledge about people with disabilities as part of teaching materials in general courses to raise other students's awareness of POW, as well as skillfull staff and adequate infrastructure. A university department has to mention what kind of disabilities are possible to be admitted in line with the education al outcome they design for the program.

\section{Bibliography}

Azzisah Y. 2015, Socio-Economic Factors on Indonesia Education Disparity, International Education Studies, Vol. 8, No. 12.

Coulson J., Education and exclusion for special needs students in Indonesia. Institute of Current World Affairs. At https://www.icwa.org/special-needs-education-indonesia-extraordinary-schools-ordinary-people/.

Data and Information Centre for Science, Disability in In- 
donesia: What Can We Learn from the Data?, https:// www.monash.edu/_data/ assets/pdf_file/0003/1107138/ Disability-in-Indonesia.pdf.

European Women Lobby. Women more prone to disability than men, and particularly vulnerable to discrimination and violence, https://www.womenlobby.org/Womenmore-prone-to-disability-than-men-and-particularlyvulnerable-to.

Halalia M.L., 2017, Pemenuhan Hak Politik Penyandang Disabilitas Sesuai Dengan Undang-Undang Nomor 8 Tahun 2016 tentang Penyandang Disabilitas oleh Komisi Pemilihan Umum (KPU) Kota Yogyakarta (Fulfillment of the Political Rights of Persons with Disabilities in Accordance with Law Number 8 of 2016 concerning Persons with Disabilities by the General Election Commission (KPU) of Yogyakarta City." Supremasi Hukum, Vol. 6.

Harvey L., 2000, New Realities: The relationship between higher education and employment, Tertiary Education and Management 6: 3-17, Netherlands: Kluwer Academic Publishers.

Human Rights. Peace, dignity and equality on a healthy planet. UN at https://www.un.org/en/sections/issuesdepth/human-rights/].

International Covenant on Economic, Social and Cultural Rights, https://www.ohchr. org/EN/ProfessionalInterest/ Pages/CESCR.aspx.

Izzo M.V., 2012, Universal Design for Learning: Enhancing Achievement of Students with Disabilities, Procedia Computer Science, Vol. 14.

Karhu, Markku. Accessible and Inclusive Studying at Higher Education Institutions in Finland. VI Congreso Internacional sobre Aplicación de Tecnologías de la Infor- 
mación y Comunicaciones Avanzadas (ATICA2014). Retrieved from http://www.esvial.org/wp-content/files/ ATICA2014pp101-108.pd.

Kementerian Pemberdayaan Perempuan dan Perlindungan Anak (Minstry of Women Empowerment and Child Protection).

Policy Brief. Gender Equality. Indonesia At https://www. kemenpppa.go.id/lib/uploads/list/eec77-buku-policybrief-genderequality.pdf.

Kementerian Sosial (The Ministry of Social Affairs). Kemensos Perluas Akses Penyandang Disabilitas terhadap Dunia Kerja Lewat Program Penjangkauan (The Ministry of Social Affairs Expands Access for Persons with Disabilities to the World of Work through Outreach Programs, https://www. jpnn.com/news/kemensos-perluas-akses-penyandang-disabilitas-terhadap-dunia-kerja-lewat-program-penjangkauan. Novianti K., 2016, Perilaku Mahasiswa Tunanetra Universitas Islam Negeri Syarif Hidayatullah Jakarta dalam Memenuhi Kebutuhan Informasi Akademik (Blind Students' Behaviours at Syarif Hidayatullah State University to Access Academic Information), Jakarta: Universitas Islam Negri Syarif Hidayatullah Jakarta.

Ministry of Research, Technology and Higher Education. Data and Information Centre for Science, Technology and Higher Education, 2018, https://pddikti.kemdikbud. go.id/asset/data/publikasi/Statistik\%20Pendidikan\%20 Tinggi\%20Indonesia\%202018.pdf.

Peraturan Menteri Pendidikan Nasional Republik Indoensia Nomor 70 TAHUN 2009. Pendidikan Inklusif bagi Peserta Didik yang Memiliki Kelainan dan Memiliki Potensi Kecerdasan dan/atau Bakat Istimewa (Decree of the Minister of National Education of the Republic of Indonesia. Number 
70/2009, on Inclusive education for students with disabilities and potential intelligence and/or special talents).

Permendikbud No 46 Tahun 2014 tentang Pendidikan Khusus., Pendidikan Layanan Khusus dan/atau Pembelajaran Khusus pada Pendidikan Tinggi (Minister of Education and Culture's decree Number 46/2014 on Special Education, Special Service Education and/or Special Learning in Higher Education.

Pusdatin (National Data Centre), 2018 Disabilitas (Disability), Indonesia.

Rakhmad M.Z., Tarahita D., 2017, Disabled Workers in Indonesia Must Be Respected, https://www.fairobserver. com/region/asia_pacific/indonesia-disabled-rightsasianworld-international-news-34450/.

Sachs D., Schreuer N., 2011, Inclusion of Students with Disabilities in Higher Education: Performance and Participation in Student's Experiences, Disability Studies Quarterly, 31 (2, http://dsq-sds.org/article/view/1593.

Sitepu I.V., Kailola LG., Hutauruk D.A., 2020, Preliminary report on ALIGN Project, Indonesia Case Study (Unpublished).

Sakenas 2019. Agustus 2019: Tingkat Pengangguran Terbuka (TPT) sebesar 5,28 Persen (National Labour Force Survey 2019. August 2019: Open Unemployment Rate is 5.28 Percent), https://www.bps.go.id/pressrele'ase/2019/.

Statistik Nasional Tahun 2020 (2020 National Statistics), https://www.bps.go.id.

UN. Human Rights. Peace, dignity and equality on a healthy planet, https://www.un.org/en/sections/issues-depth/ human-rights/.

Universal Declaration of Human Rights, Article 26, http:// www.un.org-universal-declaration-humanrights. 
Undang-undang Dasar 1945 (1945 Constitution), https:// www.mkri.id/public/content/infoumum/regulation/pdf/ UUD45\%20ASLI.pdf.

Undang-undang Nomor 20 Tahun 2003 tentang Sistem Pendidikan Nasional (Law Number 20/2002 about National Education System).

Undang-undang Nomor 8 tahun 2006 tentang Penyandang Disabilitas (Law Number 8/2006P).

Undang-undang Nomor 39 tahun 1999 tentang Hak Azasi Manusia (Law Number 39/1999 on Human Rights).

Undang-undang No. 70 Tahun 2009 tentang Pendidikan Inklusif bagi Peserta Didik yang Memiliki Kelainan dan Memiliki Potensi Kecerdasan (Law Number 70/2009 on Inclusive Education for Students with Disabilities and Disclosure and Potential Intelligence) Art. 3.

UNESCO. 2012. Global Leaders Demand Immediate Attention to Children's Education in Crisis Zones.

University of Ottawa. Understanding Barriers to Accessibility, https://www.uottawa.ca/respect/sites/; www.uottawa.ca.respect/files/accessibility-cou-understandingbarriers-2013-06.pdf.

Wikipedia. TradingNomics's Quarter 3-2020 data, https:// en.wikipedia.org/wiki/Economy_of_Indonesia.

https://www.kemdikbud.go.id/main/blog/2019/11/ayo-dukung-percepatan-pendataan-siswa-penyandang-disabilitas-di-sekolah-inklusif.

https://www.un.org/en/sections/issues-depth/humanrights/. https://www.unicef.org/media/media_65935.html. https://www.fairobserver.com/. 


\begin{abstract}
This paper discusses the right of people with disability to higher education. Education must be for all, not discriminative for every citizen of Indonesia, as stated at the 1945 Constitution. In Indonesia, children with disabilities are given attention and they can access education in schools for special children. Inclusive education means that every citizen with disability must stay in the same classroom with other students. Inclusive concept should also apply to higher education. People with disabilities should also be given the opportunity to study at the tertiary level so that they can take more part in the community, in the labour market and maybe make important decisions for their own and other people's interest. However, not too many institutions of higher learning in Indonesia are ready to admit them, due to prerequisite facilities that have to be completed by institutions before they can give access to people with disabilities; there are only a small number of higher education institutions that are ready, but not for all kinds of disabilities. Facilities provided are usually for the physically handicaped, such as students with paralytics. Poor eyesight, being hard at hearing and other types of physical handicaps are not yet given attention. The spectrum of disabilities is broad and cannot be simply generalized or categorized, especially when mental disabilities are concerned. This paper provides a general outlook of higher education facilities for people with disabilities. In order to help the readers to get a clear picture of infrastructure and other facilities needed to cater for students with disabilities, it provides a simple list of questions to help institutions or departments to better understand and prepare to welcome people with disabilities.
\end{abstract}

Keywords: Inclusive education, students with disabilities, infrastructure, higher education 